Florida International University FIU Digital Commons

\title{
Carbon and Nitrogen Stable Isotopic Patterns in South Florida Coastal Ecosystems: Modern and Paleoceanographic Perspectives
}

Samantha Lorraine Evans

Florida International University

DOI: $10.25148 /$ etd.FI10022511

Follow this and additional works at: https://digitalcommons.fiu.edu/etd

\section{Recommended Citation}

Evans, Samantha Lorraine, "Carbon and Nitrogen Stable Isotopic Patterns in South Florida Coastal Ecosystems: Modern and Paleoceanographic Perspectives" (2008). FIU Electronic Theses and Dissertations. 189.

https://digitalcommons.fiu.edu/etd/189 


\title{
FLORIDA INTERNATIONAL UNIVERSITY
}

Miami, Florida

\section{CARBON AND NITROGEN STABLE ISOTOPIC PATTERNS IN SOUTH FLORIDA COASTAL ECOSYSTEMS: MODERN AND PALEOCEANOGRAPHIC PERSPECTIVES}

\author{
A dissertation submitted in partial fulfillment of the \\ requirements for the degree of \\ DOCTOR OF PHILOSOPHY \\ in \\ GEOSCIENCES \\ by
}

Samantha L. Evans

2009 
To: Dean Kenneth Furton

College of Arts and Sciences

This dissertation, written by Samantha L. Evans, and entitled Carbon and Nitrogen Stable Isotopic Patterns in South Florida Coastal Ecosystems: Modern and Paleoceanographic Perspectives, having been approved in respect to style and intellectual content, is referred to you for judgment.

We have read this dissertation and recommend that it be approved.

René M. Price

Rudolf Jaffé

Frank J. Jochem

Peter K. Swart

Andrew W. Macfarlane

William T. Anderson, Major Professor

Date of Defense: March 23, 2009

The dissertation of Samantha L. Evans is approved.

Dean Kenneth Furton

College of Arts and Sciences

Dean George Walker

University Graduate School

Florida International University, 2009 


\section{ACKNOWLEDGEMENTS}

I wish to express my appreciation to the members of my committee, Dr. René Price, Dr. Rudolf Jaffé, Dr. Frank Jochem, Dr. Peter Swart, and Dr. Andrew Macfarlane for all their support. Special thanks must go to my major professor, Dr. William Anderson. As a mentor and friend you are without match. My project would not have been completed without your advice, enthusiasm, and constant support.

In addition, the support of Dr. Jim Fourqurean, the Florida International University Seagrass Ecosystems Laboratory (and the Seagrass Rangers, past and present), Dr. Joe Boyer, and the Southeast Environmental Research Center Water Quality Monitoring Network have been invaluable in this research, both during sample collection and analysis, and in accessing databases of water quality and seagrass isotopic composition.

Thanks to my family and friends for laughing with me through it all, for mucking about in the field, and for helping me jury rig equipment when all else had failed; and most especially to Samuel Reid, without your friendship, practicality, and unfailing support, none of this would ever have actually been finished.

Finally, I wish to thank Florida International University for providing the Dissertation Year Fellowship in support of this work, and to the Florida Coastal Everglades LTER (DEB-9910514), the American Chemical Society Petroleum Research Fund (\#38095-G2), the NSF Division of Earth Sciences Geology and Paleontology Program (\#0345812), and the FIU GSA for financial support of this research. 


\section{ABSTRACT OF THE DISSERTATION \\ CARBON AND NITROGEN STABLE ISOTOPIC PATTERNS IN SOUTH FLORIDA COASTAL ECOSYSTEMS: MODERN AND PALEOCEANOGRAPHIC PERSPECTIVES \\ by}

Samantha L. Evans

Florida International University, 2009

Miami, Florida

Professor William T. Anderson, Major Professor

Long term management plans for restoration of natural flow conditions through the Everglades increase the importance of understanding potential nutrient impacts of increased freshwater delivery on coastal biogeochemistry. The present study sought to increase understanding of the coastal marine system of South Florida under modern conditions and through the anthropogenic changes in the last century, on scales ranging from individual nutrient cycle processes to seasonal patterns in organic material (OM) under varying hydrodynamic regime, to century scale analysis of sedimentary records. In all applications, carbon and nitrogen stable isotopic compositions of OM were examined as natural recorders of change and nutrient cycling in the coastal system.

High spatial and temporal variability in stable isotopic compositions were observed on all time scales. During a transient phytoplankton bloom, $\delta^{15} \mathrm{~N}$ values suggested nitrogen fixation as a nutrient source supporting enhanced productivity. Seasonally, particulate organic material (POM) from ten sites along the Florida Reef Tract and in Florida Bay demonstrated variable fluctuations dependent on hydrodynamic 
setting. Three separate intra-annual patterns were observed, yet statistical differences were observed between groupings of Florida Bay and Atlantic Ocean sites. The POM $\delta^{15} \mathrm{~N}$ values ranged on a quarterly basis by $7 \%$, while $\delta^{13} \mathrm{C}$ varied by $22 \%$. From a sediment history perspective, four cores collected from Florida Bay further demonstrated the spatial and temporal variability of the system in isotopic composition of bulk OM over time. Source inputs of OM varied with location, with terrestrial inputs dominating proximal to Everglades freshwater discharge, seagrasses dominating in open estuary cores, and a marine mixture of phytoplankton and seagrass in a core from the boundary zone between Florida Bay and the Gulf of Mexico. Significant shifts in OM geochemistry were observed coincident with anthropogenic events of the $20^{\text {th }}$ century, including railroad and road construction in the Florida Keys and Everglades, and also the extensive drainage changes in Everglades hydrology. The sediment record also preserved evidence of the major hurricanes of the last century, with excursions in geochemical composition coincident with Category 4-5 storms. 


\section{TABLE OF CONTENTS}

CHAPTER

PAGE

1 INTRODUCTION

1.1 BACKGROUND 2

1.1.1 Florida Bay 2

1.1.2 Florida Keys Reef Tract, Florida Keys National Marine Sanctuary 8

$\begin{array}{ll}\text { 1.1.3 Stable Isotopes of Carbon and Nitrogen } & 10\end{array}$

$\begin{array}{lll}1.2 & \text { RATIONALE } & 15\end{array}$

$\begin{array}{lll}1.3 & \text { HYPOTHESES } & 17\end{array}$

$\begin{array}{lll}1.4 & \text { OBJECTIVES } & 18\end{array}$

$\begin{array}{llr}1.5 & \text { DISSERTATION ORGANIZATION }\end{array}$

$\begin{array}{ll}\text { LITERATURE CITED } & 20\end{array}$

2 SPATIAL VARIABILITY IN FLORIDA BAY PARTICULATE ORGANIC MATTER COMPOSITION: COMBINING FLOW CYTOMETRY WITH STABLE ISOTOPE ANALYSES

2.1 ABSTRACT 28

$\begin{array}{ll}2.2 & 29\end{array}$

2.3 METHODS 33

2.3.1 Setting 33

2.3.2 Sampling Locations and Collection $\quad 34$

2.3.3 Flow Cytometry Analyses $\quad 35$

2.3.4 Isotopic Analyses $\quad 36$

2.3.5 Nutrient Analyses $\quad 37$

2.4 RESULTS 37

2.5 DISCUSSION 42

$\begin{array}{lll}2.6 & \text { CONCLUSION } & 50\end{array}$

LITERATURE CITED 53

3 SPATIAL AND TEMPORAL VARIABILITY IN THE ISOTOPIC COMPOSITION OF PARTICULATE ORGANIC MATERIAL: SOURCES, CONTROLS, AND EPISODIC CHANGE

3.1 ABSTRACT

$\begin{array}{lll}3.2 & \text { INTRODUCTION }\end{array}$

3.3 METHODS $\quad 65$

3.3.1 Sampling Protocol $\quad 65$

$\begin{array}{ll}\text { 3.3.2 Flow Cytometer Analyses } & 67\end{array}$

3.3.3 Statistical Analyses $\quad 68$

3.4 RESULTS 68

3.4.1 Time Series $\quad 68$

$\begin{array}{ll}\text { 3.4.2 Size Class Variability } & 78\end{array}$

$\begin{array}{ll}3.4 .3 \text { Source indicators of POM } & 85\end{array}$

$\begin{array}{lll}3.5 & \text { DISCUSSION } & 87\end{array}$ 
3.5.1 Temporal variability and hydrodynamic regime 91

3.5.2 POM isotopic variability and water quality parameters 96

3.5.3 Florida Bay versus Atlantic Ocean pooled site characteristics 98

3.5.4 Size fractionated sampling isotopic implications 103

$\begin{array}{lll}3.6 & \text { CONCLUSIONS } & 106\end{array}$

LITERATURE CITED 108

4 STABLE ISOTOPE COMPOSITION OF SEDIMENTARY ORGANIC MATTER FROM FLORIDA BAY $\quad 117$

$\begin{array}{lll}4.1 & \text { ABSTRACT } & 118\end{array}$

$\begin{array}{lll}4.2 & \text { INTRODUCTION } & 119\end{array}$

4.3 METHODS 123

4.3.1 Setting 123

4.3.2 Sample Collection $\quad 123$

4.3.3 Geochemical Analyses 124

4.3.4 Age Dating of Sediment Cores 126

4.3.5 Statistical Analyses $\quad 127$

$\begin{array}{lll}4.4 & \text { RESULTS } & 128\end{array}$

4.4.1 Trout Creek Sediment Geochemistry 129

4.4.2 Russell Bank Sediment Geochemistry 130

4.4.3 Bob Allen Bank Sediment Geochemistry 131

4.4.4 Ninemile Bank Sediment Geochemistry 133

4.4.5 Organic carbon, total nitrogen, and total phosphorus content 134

4.4.6 Carbon and nitrogen isotopic signatures 137

$\begin{array}{lll}4.5 & \text { DISCUSSION } & 139\end{array}$

4.5.1 Isotopic and elemental source characterization 139

4.5.2 Anthropogenic influences on Florida Bay over time 147

4.5.3 Hurricane history 151

$\begin{array}{lll}\text { 4.6 CONCLUSIONS } & 157\end{array}$

LITERATURE CITED 159

5 CONCLUSIONS AND FUTURE STUDIES 168

$\begin{array}{lll}5.1 & \text { CONCLUSION } & 169\end{array}$

$\begin{array}{lll}5.2 & \text { ISOTOPIC VARIABILITY IN POM } & 170\end{array}$

5.2.1 Nitrogen fixation in transient cyanobacterial blooms 170

5.2.2 Spatial and temporal isotopic variability in size-fractionated POM 171

5.2.3 Limitations of the POM time-series 173

5.3 FLORIDA BAY SEDIMENTARY RECORDS 175

$\begin{array}{lll}5.4 & \text { FUTURE STUDIES } & 177\end{array}$

LITERATURE CITED 179

$\begin{array}{ll}\text { APPENDICES } & 181\end{array}$

$\begin{array}{ll}\text { VITA } & 209\end{array}$ 


\section{LIST OF TABLES}

TABLE

PAGE

Chapter 2 Table 2.1 Mean and S.D. of phytoplankton and bacteria population abundances determined by logical gating (Win MDI;

Trotter 1994-2000) for samples collected during the Nov. 2003 Florida Bay snapshot POM sampling. All values are cells $\mathrm{ml}^{-1} * 10^{3}$

Chapter 3 Table 3.1 POM sampling site locations and mean depths

Table 3.2 Descriptive statistics for each POM size fraction collected from 10 sites in Florida Bay and the Florida Keys National Marine Sanctuary

Table 3.3 Differences between size fractions: ANOVA P-Values

Chapter 4 Table 4.1 Florida Bay core locations, calculated average sedimentation rate, core length recovered, and depth with age constraints by ${ }^{210} \mathrm{~Pb}$ chronology

Table $4.2 \quad \delta^{13} \mathrm{C}(\%), \delta^{15} \mathrm{~N}(\%) \quad($ Mean $\pm \mathrm{SD})$

Table 4.3 Percent elemental compositions and calculated molar ratios for each core (Mean $\pm \mathrm{SD}$ )

Table 4.4 Sediment geochemical parameter means \pm st. dev. comparing pre- and post-1910 data sets

Table 4.5 Representative isotopic and elemental compositions of terrestrial verses marine organic matter sources to Florida Bay 


\section{LIST OF FIGURES}

FIGURE

PAGE

Chapter 2 Figure 2.1 Map of Florida Bay, showing sampling locations in Western Florida Bay at Sprigger Bank (1) and Ninemile Bank (2), in Northeastern Florida Bay at South Nest Key (3) and Duck Key (4), and near the Taylor Slough Everglades outflow at Trout Creek (5).

Figure 2.2 Flow cytometry analyses of Florida Bay phytoplankton collected at five sampling locations in Western (a-d) and Northeastern (e-h) Florida Bay, and proximal to the Everglades outflow (i-j).

Figure 2.3 Flow cytometry analyses of November, 2003, Florida Bay surface water bacteria samples after DNA staining with SYBR Green.

Figure 2.4 Stable isotope signals in $0.1-50 \mu \mathrm{m}$ POM collected in November 2003.

Chapter 3 Figure 3.1 Map of Florida Bay and the Florida Keys National Marine Sanctuary, showing POM sampling sites on the Atlantic Ocean side of the Florida Keys: Carysfort Reef (215), Molasses Reef (225), Tennessee Reef (243), Coffins Patch Channel (248), Bahia Honda Channel (255); and in Florida Bay: Tripod Bank (284), Bamboo Bank (287), Sprigger Bank (SP), Bob Allen Bank (BA), and Duck Key (DK).

Figure 3.2 Time series of POM isotopic values $\left(\delta^{13} \mathrm{C} \& \delta^{15} \mathrm{~N}\right)$ from 3 size fractions collected quarterly over a two year period from reef settings in the northern Florida Keys.

Figure 3.3 Time series of POM isotopic values $\left(\delta^{13} \mathrm{C} \& \delta^{15} \mathrm{~N}\right)$ from 3 size fractions collected quarterly over a two year period from reef and channel settings in the Middle Florida Keys.

Figure 3.4 Time series of POM isotopic values $\left(\delta^{13} \mathrm{C} \& \delta^{15} \mathrm{~N}\right)$ from 3 size fractions collected quarterly over a two year period from a channel setting in the Middle Florida Keys. 
Figure 3.5 Time series of POM isotopic values $\left(\delta^{13} \mathrm{C} \& \delta^{15} \mathrm{~N}\right)$ from 3 size fractions collected quarterly over a two year period from shallow mudbank settings in Western 74 Florida Bay.

Figure 3.6 Time series of POM isotopic values $\left(\delta^{13} \mathrm{C} \& \delta^{15} \mathrm{~N}\right)$ from 3 size fractions collected quarterly over a two year period from a shallow mudbank setting in Western Florida Bay.

Figure 3.7 Time series of POM isotopic values $\left(\delta^{13} \mathrm{C} \& \delta^{15} \mathrm{~N}\right)$ from 3 size fractions collected quarterly over a two year period from shallow mudbank settings proximal to both islands and Everglades outflows in Northeastern and Central Florida Bay.

Figure 3.8 Mean annual patterns in $\delta^{15} \mathrm{~N}$ values; 2 years combined.

Figure 3.9 Variation in $\delta^{13} \mathrm{C}$ between POM size fractions combining ten sampling intervals.

Figure 3.10 Variation in $\delta^{15} \mathrm{~N}$ between POM size fractions combining ten sampling intervals.

Figure 3.11 Variation in $\delta^{15} \mathrm{~N}$ between POM size fractions during individual sampling intervals.

Figure 3.12 Bivariate isotope plots of $\delta^{13} \mathrm{C}$ and $\delta^{15} \mathrm{~N}$ for the three size fractions.

Figure 3.13 Bivariate plots of $\delta^{13} \mathrm{C}$ and $\delta^{15} \mathrm{~N}$ with Molar $\mathrm{C}: \mathrm{N}$ ratio for the three size fractions.

Figure 3.14 Flow cytometry analyses of Florida Keys Reef Tract phytoplankton collected quarterly at 5 stations along a $\mathrm{N}-\mathrm{S}$ transect down the Florida Keys.

Figure 3.15 Flow cytometry analyses of Florida Bay phytoplankton collected quarterly at 5 stations in the bay.

Figure 3.16 Conceptual model illustrating the distribution of South Florida coastal hydrodynamic zones as they influence nutrient dynamics and POM isotopic composition over time. 
Figure 3.17 Bivariate plots of $\delta^{13} \mathrm{C}$ and $\delta^{15} \mathrm{~N}$ with Log Chlorophyll$a$ for the $50-150 \mu \mathrm{m}$ size fraction, dominated by autotrophic diatoms and dinoflagellates.

Figure 3.18 Isotopic values of size fractionated and bulk POM samples collected at Molasses Reef (this study) and Dixie Shoals (purple circles, Lamb 2006; collected in 2000-2002).

Chapter 4 Figure 4.1 Map of Florida Bay, showing core collection sites at Ninemile Bank, Bob Allen Key, Russell Bank, and Trout Creek.

Figure 4.2 Geochemical dataset from the upper $92 \mathrm{~cm}$ of a core collected from the mouth of Trout Creek, Northeastern Florida Bay.

Figure 4.3 Geochemical dataset from a $166 \mathrm{~cm}$ long core collected at Russell Bank, Central Florida Bay.

Figure 4.4 Geochemical dataset from the upper $66 \mathrm{~cm}$ of a core collected from Bob Allen Bank, Central Florida Bay.

Figure 4.5 Geochemical dataset from the upper $66 \mathrm{~cm}$ of a core collected from Ninemile Bank, Western Florida Bay.

Figure 4.6 Sediment elemental composition data over time at four sites in Florida Bay expressed in weight \%.

Figure 4.7 Carbon and nitrogen isotopic data from four Florida Bay cores: Bob Allen Bank (BA), Russell Bank (RB), Trout Creek (TC), and Ninemile Bank (9M).

Figure 4.8 Carbon isotopic data from all Florida Bay cores plotted with two ${ }^{13} \mathrm{C}$ datasets from Swart et al., a coral record (Swart et al. 1996) and a sclerosponge record (Swart et al. 2002).

Figure 4.9 Carbon and nitrogen isotope stratigraphy from the four Florida Bay cores highlighting isotopic evidence of hurricane disturbance. 
CHAPTER 1

INTRODUCTION 


\subsection{BACKGROUND}

South Florida's coastal environment represents a diverse and interconnected range of geomorphological settings and biological habitat types; transitioning from the fresh to brackish water mangrove ecotone through the shallow estuarine environment of Florida Bay to channel settings between the Florida Keys islands and beyond to the coral reef and hardbottom systems of the Atlantic nearshore zone. Over the past 50 to 100 years, all of these environments have been impacted by enormous changes in urbanization and population growth in South Florida, which have led to significant changes in the hydrology of the system and anthropogenic nutrient delivery. The present study has sought to increase understanding of these interconnected systems both under modern conditions and through the course of anthropogenic change in the last century, on scales ranging from individual processes of nutrient cycling to seasonal patterns in particulate organic material under varying hydrodynamic regime, to century-scale analysis of sedimentary records. In all these applications, carbon and nitrogen stable isotopic compositions of organic material have been examined as natural recorders of change and nutrient cycling in the coastal zone.

\subsubsection{Florida Bay}

Florida Bay is a shallow estuarine lagoon of $>2200 \mathrm{~km}^{2}$ in areal extent lying between the South Florida mainland and the Florida Keys. The bay is bounded to the north with the mangrove wetlands of the southern Everglades, to the west with the open marine systems of the Southwest Florida Shelf and Gulf of Mexico, and to the south by the islands of the Florida Keys, connected via several channels to the coastal Atlantic and 
the Florida Reef Tract. Thus, Florida Bay represents a dynamic region of exchange for three distinct hydrologic systems in South Florida.

The bay itself consists of a series of shallow basins ( $<3 \mathrm{~m}$ depth) separated hydrologically by a network of subtidal mudbanks and mangrove islands which restrict water mixing between basins and attenuate both tidal amplitude and current. Freshwater runoff, comparatively rich in dissolved inorganic nitrogen (DIN) and poor in soluble reactive phosphorus (SRP), enters this hydrologically complex system primarily in Northeastern Florida Bay through the Taylor Slough and the C-111 basin. Saline ocean water, comparatively depleted in DIN and enriched in SRP, enters across the western boundary with the Gulf of Mexico and through numerous tidal channels crossing the Florida Keys (Boyer et al. 1999). Interaction between these inflows and limitations on the bay’s mixing regime serve to generate gradients in both salinity and nutrient availability across the bay.

Florida Bay has been influenced by changes in the timing and volume of freshwater flow from the Everglades in the last half century as a result of extensive modification of the natural discharge patterns by water management canalization and levee construction (Davis and Ogden 1994, Rudnick et al. 1999). These hydrological changes have prompted researchers to explore the extent to which salinity levels in the bay have been affected by these changes (Huvane 2002). Further, human alteration of the Everglades watershed in favor of agriculture and urbanization may have increased nutrient loads to downstream Florida Bay, adding research questions investigating impacts of this cultural eutrophication in the system (Fourqurean et al. 1993, Boyer et al. 1999). Historically, the Florida Bay ecosystem is thought to have been a shallow, 
optically clear lagoon characterized by low nutrient levels and populated by abundant seagrass communities. However, in recent years significant changes have been observed in water clarity, hypersaline conditions have periodically developed during summer months, and widespread die offs have occurred in the seagrass communities, coincident with extensive phytoplankton blooms (Robblee et al. 1991, Phlips and Badylak 1996, Phlips et al. 1999, Glibert et al. 2004). Although there has been growing concern that biotic shifts are related to anthropogenic changes in Everglades flow and increasing nutrient inputs from the Florida Keys and the Gulf of Mexico, it is also questioned whether the changes are a consequence of natural phenomena, such as climatic fluctuation or ecological succession cycles (Lapointe and Clark 1992, McIvor et al. 1994, Lapointe et al. 1994, Swart et al. 1999).

Long term proxy records of environmental change, for example those found in coral skeletons (Smith et al. 1989, Swart et al. 1996, Swart et al. 1999) and those in sedimentary records (Halley and Roulier 1999, Brewster-Wingard and Ishman 1999, Brewster-Wingard et al. 2001, Huvane and Cooper 2001, Cronin et al 2001, Xu et al. 2007), can provide a baseline understanding of how the South Florida system has changed through time over the last 100 to 3000 years, however there is some discordance between different proxies. Coral fluorescence and isotopic values $\left(\delta^{13} \mathrm{C}\right.$ and $\left.\delta^{18} \mathrm{O}\right)$ recorded in annular growth rings from Solenastrea bournoni corals from Lignumvitae Basin both imply that there has been no long term change in salinity over the last 175 years, however changes in water management practices circa 1940 were in fact recorded in fluorescence patterns (Smith et al. 1989, Swart et al. 1999). A slight increase in salinity coincident with restriction in circulation related to closure of Florida Keys 
channels during construction of the Overseas Railway (1907-1912) was also evident in coral isotopic records (Swart et al. 1999). In contrast to the salinity reconstruction of Swart et al. (1996), Brewster-Wingard and Ishman (1999) and Brewster-Wingard et al. (2001) demonstrated that the average salinity of Florida Bay has been increasing since 1880 and that salinity fluctuations have been more frequent and of greater amplitude since the beginning of the $20^{\text {th }}$ century based on molluscan and foraminiferal assemblages in several cores from central Florida Bay. Additionally, the presence of the euryhaline bivalve, Brachiodontes, also tolerant of decreases in water quality (i.e. increasing nutrient content and decreasing water clarity) indicates deterioration of the ecosystem after water management structures were implemented in the Everglades watershed beginning in 1930. Similar findings were reported by Huvane and Cooper (2001) based on diatom assemblage changes in central and NE Florida Bay cores. The reliable chronology of these studies extended less than 200 years, but changes in speciation around 1940 imply increases in salinity related to canalization of the Everglades and ensuing reduction of freshwater discharge to Florida Bay. Increases in the ratio of planktonic to benthic diatoms observed since 1940 also suggest declining water quality, as planktonic algal blooms are related to increases in nutrient availability. Decreases in epiphytic diatom populations suggest declines in seagrass habitat over time, consistent also with correlations to declining water quality in Florida Bay in the past 100 years.

In light of the eight billion dollar Comprehensive Everlades Restoration Project (CERP) and current efforts to restore the Everglades ecosystem, including Florida Bay, to a "pristine" state, it is important to understand the natural state of the system. Quantitative meteorological, ecological, and water quality datasets extend only to the 
1950s, post-dating many significant anthropogenic alterations of the system, thus paleoecological and paleoceanographic reconstructions have become increasingly important to management decisions. Several proxy indicators have been applied to core chronologies as highlighted above, however there may be up to 4000 years of environmental record remaining to be interpreted due to paucity in datable material down-core. Further, although the above mentioned work focused on salinity and water quality parameters in the bay over time, none address the specific history of seagrass distributions or the frequency of planktonic algal blooms in Florida Bay. In addition, while many studies have utilized paleoecological proxies, only a few have employed sediment geochemical parameters (Orem et al. 1999, Nelson et al. 2002), and in these cases sampling resolution was relatively low, limiting the interpretation of processes occurring on restricted temporal scales.

While understanding the historical environment of Florida Bay is integral to accurate planning of restoration efforts, the system as it functions today must be characterized so that alterations during the process of restoration may be recognized. Ecological studies are of course numerous, and water quality monitoring has been a focus over the previous two decades (Boyer et al. 1997, 1999, Rudnick et al. 1999) as efforts continue to gain insight into observed ecosystem-wide changes (Fourqurean and Robblee 1999). However, research aimed at understanding nutrient cycling from an isotopic perspective is isolated. Studies of seasonal and spatial variability in isotopic composition and elemental content of seagrasses in Florida Bay suggest significant variations not only in productivity and fractionation in the seagrasses themselves, but also in nutrient source inputs and in seasonal processing through microbially mediated nitrogen cycling 
reactions. In addition, there is defined seasonal variability in carbon isotopic composition which is dependent upon growth rate and possibly freshwater dissolved inorganic carbon delivery (Anderson and Fourqurean 2003, Fourqurean et al. 2005). Behringer and Butler (2006) examined carbon sources in Florida Bay hardbottom communities, citing the benthic macroalgal community as the dominant source of secondary production to these ecosystems rather than seagrass or phytoplankton. Yet, while seasonal isotopic changes in these dominant benthic producers have been well constrained in efforts to relate geochemical indicators to surface nutrient processes, very little has been done with regards to understanding isotopic changes in water column communities within Florida Bay. Studies by Williams et al. (2009) determined that Florida Bay phytoplankton biomass is dominated by pico- and nano-plankton and cyanobacteria are the main bloomforming group in the bay, confirming previous efforts (Phlips et al. 1995, 1999; Lavrentyev et al. 1998). However, Maie et al. (2005) suggested that much of the pelagic organic matter is not associated with living microbial (bacteria and algae) biomass but is detritus originating from seagrass and algae which is in some environments augmented by periodic influx of organic matter from the Everglades. Additionally, Xu and Jaffé (2007) reported significant differences in POM composition between wet and dry seasons in Florida Bay as indicated by a suite of organic biomarkers. While wet season POM was dominated by marine phytoplankton, dry season samples demonstrated more terrestrial influence reflecting the magnitude of marine primary productivity during wet season nutrient inputs (Xu and Jaffé 2007). These POM studies studies suggest high levels of variability in composition of water column particulate organics. Further investigation of this variability applying stable isotopic tools to clarify seasonal patterns, perhaps relating 
OM sources to nutrient processes, might further understanding of the system as a whole, adding an additional component to previously developed and ongoing geochemical monitoring.

\subsubsection{Florida Keys Reef Tract, Florida Keys National Marine Sanctuary}

The Florida Keys Reef Tract consists of a series of coral reefs broken by shallow channels, separated from shore by 5 to $8 \mathrm{~km}$ of water ranging in depth from 3 to $10 \mathrm{~m}$. With the exception of reef systems surrounding Bermuda, the reefs of the Florida Keys represent some the northernmost latitudinal limits of Caribbean coral species. These communities have moderate percent areal cover (10-50\%) of hard and soft corals, benthic algae, and sponges (Leichter et al. 2008). Reef crests lie at 3 to $10 \mathrm{~m}$ depth, with forereefs sloping to 30 to $35 \mathrm{~m}$ depth, becoming gradually discontinuous until they are semi-isolated patches on sand. Seaward of the reef tract, the bottom slopes such that depth increases by 10-20 m per km until reaching the edge of the Florida Shelf, where slope angle increases into the deep channel of the Florida Straits (depths of 800-1200 m between 70 and $100 \mathrm{~km}$ offshore). The Florida Current is typically located between 10 and $40 \mathrm{~km}$ seaward of the reef tract flowing between 0.5 and $1.5 \mathrm{~m} \mathrm{~s}^{-1}$ to the NE (Leichter et al. 2008). In terms of hydrodynamic regime, the reef tract is exposed to the episodic input of nutrients from upwelling and associated uplift of isotherms by frontal eddies of the Florida Current and internal waves acting at tidal frequencies (Leichter et al. 2003). High levels of both inorganic nitrogen and phosphorus below the thermocline point to the potential for the offshore nutrient pool to be a significant source of nutrients during these episodic upwelling events. In addition, the exchange of water through tidal channels 
connecting the Gulf of Mexico/Florida Bay to the Atlantic Ocean is an important feature of regional circulation, carrying a net outflow of nutrients from Florida Bay, which may then be advected toward the reef tract (Smith 1998, Gibson et al. 2008).

In the last three decades, human activities in the Florida Keys have almost doubled, with concomitant increases in waste/nutrient inputs, thus a large body of recent research has investigated the impact of nutrient releases on the sensitive coral ecosystem of the reef tract (Lapointe and Clark 1992, Lapointe et al. 2004, Ward-Paige et al. 2005). Results are contradictory, with several investigators citing anthropogenic waste having a severe impact, particularly based on arbitrarily assigned isotopic indicator points (Lapointe et al. 2004 Ward-Paige et al. 2005), while others maintain that upwelling events related to internal tidal bores supply over 30 times more phosphorus and nitrogen that all estimated anthropogenic inputs from the Keys (Szmant and Forrester 1996, Leichter et al. 2003). Recent studies of the isotopic composition of the regionally dominant seagrass, Thalassia testudinum, also contradict the pervasiveness of anthropogenic nutrient disturbance, with seagrass tissues exhibiting $\delta^{15} \mathrm{~N}$ values ranging between -0.5 and $+4.0 \%$ (Anderson and Fourqurean 2003, Fourqurean et al. 2005), generally lower than those commonly associated with anthropogenic waste nutrient pollution. Further, the extensive investigation of Lamb (2006) into reef nutrient dynamics failed to demonstrate isotopic evidence of significant anthropogenic contamination in particulate organic material along numerous inshore to offshore transects along the Florida Keys Reef Tract (Lamb and Swart 2008). Similar to Florida Bay, while much work has been done in the Florida Keys National Marine Sanctuary investigating the isotopic composition of benthic macrophyte and macroalgal 
communities (Lapointe and Clark 1992, Lapointe et al. 2004, Anderson and Fourqurean 2003, Fourqurean 2005), very little has been done to investigate spatial and temporal variability in the isotopic composition of water column particulate organic material (Lamb and Swart 2008). The present study builds upon the work of Lamb (2006), further clarifying nutrient and particulate sources in the nearshore environment of the Florida Keys Reef Tract, and adds to our understanding of nutrient processes in the South Florida coastal zone.

\subsubsection{Stable Isotopes of Carbon and Nitrogen}

Nitrogen and carbon isotopic ratios $\left({ }^{15} \mathrm{~N} /{ }^{14} \mathrm{~N}\right.$ and $\left.{ }^{13} \mathrm{C} /{ }^{12} \mathrm{C}\right)$ in sedimentary and suspended particulate organic matter, precipitating inorganic material, and residual water column dissolved pools are presently being explored as unique natural recorders of marine nutrient cycling, biogeochemistry, and primary productivity (Wu et al. 1997, Altabet et al. 1999, Waser et al. 2000, and others). $\delta^{13} C^{*}$ signatures have been widely used in both lacustrine and marine sediments not only as indicators of organic matter source, but also as indicators of enhanced aquatic productivity (McKenzie 1985, Calvert et al. 1992, Shamesh et al. 1993, Minoura et al. 1997, Schubert and Calvert 2001). $\delta^{13} \mathrm{C}$ signature may be used as a productivity indicator because photosynthetic discrimination processes preferentially incorporate ${ }^{12} \mathrm{C}$, thus the resultant organic matter is relatively “depleted” in terms of ${ }^{13} \mathrm{C}$, leaving the dissolved carbon pool in the photic zone and subsequently generated organic carbon enriched in ${ }^{13} \mathrm{C}$ (McKenzie 1985, Hollander and

\footnotetext{
${ }^{*} \delta^{13} \mathrm{C}(\%)=\left[\left({ }^{13} \mathrm{C} /{ }^{12} \mathrm{C}_{\text {sample }}{ }^{13} \mathrm{C} /{ }^{12} \mathrm{C}_{\text {standard }}\right)-1\right] * 1000$

$\delta^{15} \mathrm{~N}(\%)=\left[\left({ }^{15} \mathrm{~N} /{ }^{14} \mathrm{~N}_{\text {sample }}{ }^{15} \mathrm{~N} /{ }^{14} \mathrm{~N}_{\text {standard }}\right)-1\right] * 1000$
} 
McKenzie 1991). During periods of high or increased primary productivity, photic zone depletion of the light isotope may force decreases in discrimination, increasing the relative proportion of ${ }^{13} \mathrm{C}$ that is fixed (Brenner et al. 1998, Muller and Voss 1999). Further, rapid rates of primary production may deplete the water column of the available free aqueous $\mathrm{CO}_{2}$, and some aquatic primary producers may increasingly rely on enriched bicarbonate $\left(\mathrm{HCO}_{3}{ }^{-}\right)$as a carbon source consequently producing ${ }^{13} \mathrm{C}$-enriched organic matter (Fogel et al. 1992, Eadie et al. 1994, Muller and Voss 1999).

More recently, $\delta^{15} \mathrm{~N}$ values have become a complimentary proxy in both modern and paleoceanographic settings (Calvert et al. 1992, Francois et al. 1992, Teranes and Bernasconi 2000). Nitrogen isotopes behave much like carbon isotopes during biotic uptake and utilization in the euphotic zone. In non-limiting environments, lighter ${ }^{14} \mathrm{~N}$ is preferentially incorporated in plant biomass and is subsequently recycled in higher trophic levels, buried, or released through denitrification processes as non-bioavailable $\mathrm{N}_{2}$ gas. More commonly, nitrogen is in limited supply dependent on seasonal upwelling and/or discharge. Studies show that the $\delta^{15} \mathrm{~N}$ of organic matter is inversely related to the degree of surface water nitrate $\left(\mathrm{NO}_{3}{ }^{-}\right)$consumption where $\mathrm{N}$ is a limiting nutrient. As the $\mathrm{NO}_{3}{ }^{-}$concentrations progressively decline the residual $\mathrm{NO}_{3}{ }^{-}$pool becomes isotopically enriched and is then exploited to support autotrophic productivity (Wu et al. 1997, Altabet et al. 1999, Sigman et al. 2000, Waser et al. 2000, Mahaffey et al. 2003, Mahaffey et al. 2004). Many researchers then interpret enriched $\delta^{15} \mathrm{~N}$ values as indicative of high productivity, or more specifically high surface nitrate utilization (Wainright and Fry 1994, Wu et al. 1997, Altabet et al. 1999, Rolff 2000, Waser et al. 2000). 
In the last decade, many studies have shown that combined interpretations of the carbon and nitrogen isotopic systems generate a more complete picture of productivity levels and nutrient utilization (Ostrom et al. 1997, Brenner et al. 1999, Muller and Voss 1999, Struck et al. 2001, Schubert and Calvert 2001). When both carbon and nitrogen are limiting, their isotopic signatures can be expected to show a positively correlated enrichment trend with increasing productivity. Alternatively, an inverse relationship will be evident between $\delta^{13} \mathrm{C}$ and $\delta^{15} \mathrm{~N}$ trends should one of the nutrients be abundant while the other is limiting under increasing productivity (Schubert and Calvert 2001). Supporting $\delta^{13} \mathrm{C}$ and $\delta^{15} \mathrm{~N}$ values with C:N:P (Redfield ratios) from organic matter can further clarify nutrient limitation trends and primary productivity interpretations (Anderson and Fourqurean 2003). However, interpreting stable isotope ratios in terms of productivity is not without caveat. Nitrogen isotopes present a particular problem, especially in systems where phosphorus is more limiting than nitrogen, as in many lacustrine and some marine environments, for example the carbonate based system of coastal Florida (Fourqurean and Zieman 1992, Millero et al. 2001). In these environments, only part of the ambient dissolved inorganic nitrogen (DIN) pool is consumed and the residual DIN isotopic composition may never be appreciably altered. Under these conditions, primary productivity cannot be inferred from the $\delta^{15} \mathrm{~N}$ of organic matter in the system, because other factors often more strongly influence the $\mathrm{N}$-isotopic signal (Teranes and Bernasconi 2000). For example, the concentration of DIN can be more variable than DIC concentrations at the surface, which in turn can cause variations in the $\delta^{15} \mathrm{~N}$ of the $\mathrm{N}$-source. In addition, variations in the dissolved $\mathrm{N}$-species may further convolute this problem. Ammonium $\left(\mathrm{NH}_{4}{ }^{+}\right)$may be utilized by autotrophs as an 
alternative to $\mathrm{NO}_{3}{ }^{-}$, however the isotopic signature of ammonium can vary from extremely depleted $\delta^{15} \mathrm{~N}$ values in excretion products to enriched values if produced through ammonification of primary organic matter (Ostrom et al 1997). Further, dissolved $\mathrm{NH}_{4}{ }^{+}$is also more highly fractionated during biotic uptake than $\mathrm{NO}_{3}{ }^{-}$ (fractionation $(\varepsilon)=6.5-9.0 \%$ in $\mathrm{NH}_{4}{ }^{+}$whereas $\varepsilon=2-5 \%$ in $\mathrm{NO}_{3}$; Waser et al. 2000). This difference in fraction might lead to differential residual ${ }^{15} \mathrm{~N}$ enrichment between $\mathrm{NH}_{4}{ }^{+}$and $\mathrm{NO}_{3}{ }^{-}$at similar uptake rates, complicating assumptions that enrichment signatures are indicative of $\mathrm{NO}_{3}{ }^{-}$dependence/limitation in the system being examined. In addition, denitrification operating in anoxic basins and anoxic zones within the sediment can also be expected to enrich the dissolved $\mathrm{N}$ pool in ${ }^{15} \mathrm{~N}$, whereas $\mathrm{N}$-fixation inputs of relatively depleted $\delta^{15} \mathrm{~N}$ may offset the expected enrichment, disguising the productivity signature (Eadie et al. 1994, Hodell and Schelske 1998).

Shifts in autotrophic species composition or addition of heterotrophs can also influence the $\delta^{15} \mathrm{~N}$ composition of sedimenting organic matter. The organic matter $\delta^{15} \mathrm{~N}$ composition is even more affected by shifts favoring diazetrophic N-fixing species, which generate delta values near the atmospheric standard, 0\%o (Eadie et al. 1994, Hodell and Schelske 1998, Schubert and Calvert 2001). Understanding speciation changes may be particularly important in interpreting seasonal variability in planktonic isotopic signatures, as the species composition of the community varies considerably over seasonal cycles with changing nutrient availability, and also with a variety of other environmental parameters including temperature, salinity, irradiance, etc. (Boyer et al. 1997). Additionally, changes in trophic structure may also influence the both $\delta^{15} \mathrm{~N}$ and to 
a lesser extent the $\delta^{13} \mathrm{C}$ of organic matter, as it is well known that $\delta^{15} \mathrm{~N}$ increases by $3-4 \%$ and $\delta^{13} \mathrm{C}$ increases by about 1\%o per trophic transfer (Peterson and Fry 1987). Isotopic variation will also be introduced by variations in the proportions of macrophytes versus algae contributing to sedimentary organic matter, as well as terrestrial versus marine inputs - all of which show significant differences in both $\delta^{13} \mathrm{C}$ and $\delta^{15} \mathrm{~N}$ signatures (Brenner et al. 1999, Muller and Voss 1999). Further complication of terrestrial versus marine isotopic signals has been highlighted by recent work examining isotopic responses in wetland plant tissues with changes in water level, hydro-period, precipitation, and salinity stress. Wide variations in the isotopic composition of wetland plants and trees can be induced by localized environmental conditions because changes in water use efficiency can alter carbon assimilation rates and isotopic discrimination associated with photosynthesis (Anderson et al. 2005, Ewe and Sternberg 2002, 2003). Anoxia in saturated root zones can induce decreases in stomatal conductance, causing isotopic enrichment (Ewe and Sternberg, 2002, 2003, Anderson et al. 2005). In this manner then, seasonal changes in precipitation and transitions through the drought cycle can be expected to significantly alter the isotopic composition of wetland macrophyte detritus entering the coastal zone. Anderson et al. (2005) showed a positive correlation between precipitation and pond cypress isotopic composition in the freshwater Everglades, thus longer hydro-period in the upstream Everglades may lead to isotopic enrichment in particulate detritus. Salinity stress, though seeming to be the opposite of water stress associated with increases in freshwater hydro-period, may also induce decreases in stomatal conductance and ensuing isotopic enrichment (Anderson et al. 2005). The $\delta^{13} \mathrm{C}$ enrichment under both water stress cases is significant enough to 
generate confusion between terrestrial and marine isotopic signals, as both pond cypress under freshwater stress and bald cypress under salinity stress exhibited cellulose $\delta^{13} \mathrm{C}$ values between -20 and -22\%; values that are conventionally considered diagnostic of planktonic marine organic material.

Before $\mathrm{C}$ and $\mathrm{N}$ isotopic signals can be interpreted with confidence in terms of paleoproductivity and nutrient limitation in time-series data sets or core stratigraphy, processes as they occur locally in modern environments must be understood. As always, the present is the key to the past and examining modern analogues is important for calibrating development in a system over time, which will lead to improved reconstructions.

\subsection{RATIONALE}

In the case of Florida Bay, stable isotopic signatures recorded in both sedimentary and suspended organic matter represent useful tools to gain understanding of carbon and nitrogen cycling in a shallow carbonate estuary. Although nutrient budgets have been constructed for Florida Bay, and the flux magnitudes of internal N-cycling chemical processes are the subject of ongoing work (Rudnick et al. 1999, Nagel 2004, Cornwell et al. unpublished data). Thus far, the $\mathrm{N}$ dynamics within the system have not been well constrained in terms of changing availability of DIN species and their relative utilization by both benthic and planktonic autotrophs. $\delta^{15} \mathrm{~N}$ has not been measured on a comprehensive level in POM in the system and no efforts have yet been made to clarify finer points in the N-cycle of Florida Bay using $\mathrm{N}$ stable isotopes. Although there have been studies applying $\delta^{13} \mathrm{C}$ values to track organic carbon sources in particulate organic 
carbon (POM) delivery to the bay via Taylor Slough and Shark River Slough (Mead 2004), the N isotopes in this freshwater POM discharge have not been examined, yet this material may represent a significant component of the Florida Bay N-cycle. Further, isotopic studies of the estuarine food web have been completed (Zieman et al. 1984, Harrigan et al. 1989); however, analysis of spatial and temporal variations $\mathrm{C}$ and $\mathrm{N}$ isotopic composition of organic matter related to seasonal productivity changes has been limited to the regionally dominant seagrass, Thalassia testudinum (Anderson and Fourqurean 2003). Three years of quarterly $\delta^{13} \mathrm{C}$ and $\delta^{15} \mathrm{~N}$ measurements on Thalassia, collected from sites on both the ocean and bay sides of the Florida Keys, show that the seasonal variability observed in seagrass productivity is also present in the isotopic signals of both $\mathrm{N}$ and C. However, relationships between the two isotopic systems vary on both spatial and temporal scales, potentially demonstrating nutrient decoupling between the driving mechanisms behind variability in $\mathrm{C}$ and $\mathrm{N}$ isotopic signatures (Anderson and Fourqurean 2003).

The seagrass community is only one component of the local N-cycle. The phytoplankton/POM isotopic signal is a significant missing element that has yet to be documented. Due to the nature of the planktonic community - high population turn-over rates, variable transport mechanisms within the water column, and the tight coupling between both phytoplankton productivity, speciation, and seasonal environmental changes - $\delta^{13} \mathrm{C}$ and $\delta^{15} \mathrm{~N}$ signals are expected to exhibit more spatial and temporal variability than the macrophytes. Additionally, rooted aquatic vegetation primarily responds to nutrient concentrations available in pore water, whereas the pelagic community reacts directly to surface water quality (Fourqurean et al. 1992). For the same 
reasons, the phytoplankton may also show pronounced responses to changes in nutrient source and availability much more quickly than the macrophyte community, thus the suspended community might represent a better tool for constraining seasonality and spatial variability in $\mathrm{N}$-cycling.

Short term seasonal variability has been identified in benthic macrophyte communities of a magnitude equal to long term fluctuations observed in geologic records for the Phanerozoic. In order to apply stable isotope systematics as a tool to understand and predict future change in the system it is important to first establish modern baseline data, particularly in the context of biological productivity, and the extent of natural/seasonal variations before geologic records can be interpreted. As such, the purpose of this work was to more completely constrain modern $\mathrm{C}$ and $\mathrm{N}$ cycling in Florida Bay and the adjacent Florida Keys near-shore reef system in terms of $\delta^{13} \mathrm{C}$ and

$\delta^{15} \mathrm{~N}$. In particular, variability in carbon and nitrogen isotopic values was investigated Findings in the modern environment will then be applied to the sedimentary record of Florida Bay, possibly shedding light on past nutrient cycling, organic matter sources, and paleoproductivity in the bay and adjacent systems.

\subsection{HYPOTHESES}

The work described here is based on the following set of hypotheses:

Hypothesis 1: Organic matter sources comprising the total pool of particulate organic material in South Florida coastal ecosystems are variable on a seasonal basis, reflecting productivity changes in various biological components of the system, wet-dry season 
cycles in freshwater flow delivery, and seasonal climate patterns (wind, storm forcing, etc.).

Hypothesis 2: Patterns in the spatial and temporal variability of particulate organic material stable isotopic composition are related to seasonal changes in nutrient availability.

Hypothesis 3: Spatial variability evident in the isotopic compositions of both particulate organic material and benthic seagrasses is preserved in sedimentary organic material.

\subsection{OBJECTIVES}

To approach the purpose and set of hypotheses stated above, the following research objectives were addressed:

1. A size-fractionated, seasonal particulate organic matter isotopic time series will be generated broadly separating zooplankton, larger phytoplankton, and smaller phytoplankton/bacterial components for ten sites within Florida Bay and along the Florida Reef Tract in an effort to understand autochthonous particulate inputs and cycles to the coastal system.

2. Spatial and temporal variability in the POM isotopic time series will be compared to the existing and continuing data set of the isotopic composition of seagrass, and to available data sets of ambient DIN availability to assess relationships among parameters. 
4. The sedimentary record of Florida Bay will be interpreted in terms of variation in organic matter source, paleoproductivity, relative nutrient utilization, and changing nutrient sources over the geologic history of Florida Bay using organic matter $\delta^{13} \mathrm{C}$ and $\delta^{15} \mathrm{~N}$ measurements from dated sediment cores.

\subsection{DISSERTATION ORGANIZATION}

Chapter 1 provides background information for this study. General descriptions of carbon and nitrogen isotope theory are given, followed by an introduction to the current state of applicable research in both Florida Bay and along the Florida Reef Tract.

Chapters 2 through 4 represent the main body of research conducted in the present study, examining components of the isotopic systematics of the South Florida marine system at a variety of time scales. At the process level, organic matter stable isotopic values were applied to assess nutrient acquisition mechanisms in a single transient cyanobacterial bloom event (Chapter 2). From a longer term seasonal point of view, isotopic values demonstrated a high level of spatial and temporal variability in particulate organic matter, supporting previous work characterizing the significance of hydrodynamic regime as a control on coastal processes (Chapter 3). Increasing the scale further, geochemical data was utilized to assess organic matter source and identify markers of disturbance in the last century (Chapter 4).

Chapter 5 presents a synthesis of results showing the relationships between isotopic records across the time-scales examined and outlines possible future research directions. 


\section{LITERATURE CITED}

Altabet, M.A., C. Pilskaln, R. Thunell, C. Pride, D. Sigman, F. Chavez, R. Francois. 1999. The nitrogen isotope biogeochemistry of sinking particles from the margin of the Eastern North Pacific. Deep Sea Research I 46:655-679.

Anderson, W.T., and J.W. Fourqurean. 2003. Intra- and Interannual variability in seagrass carbon and nitrogen stable isotopes from South Florida, a preliminary study. Organic Geochemistry 34:185-194.

Anderson, W.T., L.S.L. Sternberg, M.C. Pinzon, T. Gann-Troxler, D.L. Childers, M. Duever. 2005. Carbon isotopic composition of cypress trees from South Florida and changing hydrologic conditions. Dendrochronologia 23:1-10.

Behringer, D.C., and M.J. Butler, IV. 2006. Stable isotope analysis of production and trophic relationships in a tropical marine hard-bottom community. Oecologia 148:334-341.

Boyer, J.N., J.W. Fourqurean, R.D. Jones. 1999. Seasonal and long term trends in the water quality of Florida Bay (1989-1997). Estuaries 22:417-430.

Boyer, J.N., J.W. Fourqurean, R.D. Jones. 1997. Spatial characterization of water quality in Florida Bay and Whitewater Bay by multivariate analyses: Zones of similar influence. Estuaries 20:743-758

Brenner, M., T.J. Whitmore, J.H. Curtis. 1999. Stable isotope $\left(\delta^{13} \mathrm{C}\right.$ and $\left.\delta^{15} \mathrm{~N}\right)$ signatures of sedimented organic matter as indicators of historic lake trophic state. Journal of Paleolimnology 22:205-221.

Brewster-Wingard, G.L., J.R. Stone, C.W. Holmes. 2001. Molluscan faunal distribution in Florida Bay, past and present: An integration of down-core and modern data. Bulletin of Marine Science 44:199-231.

Brewster-Wingard, G.L., S.E. Ishman. 1999. Historical trends in salinity and substrate in Central Florida Bay: A paleoecological reconstruction using modern analogue data. Estuaries 22:269-283.

Calvert, S.E., B. Neilson, and M. Fontugne. 1992. Evidence from nitrogen isotope ratios for enhanced productivity during formation of eastern Mediterranean sapropels. Nature 359:223-225.

Cronin, T.M., G.S. Dwyer, S.B. Schwede, an others. 2002. Climate variability from the Florida Bay sedimentary record: possible teleconnections to ENSO, PNA, and CNP. Climate Research 19:233-245.

Davis, S.M. and J.C. Ogden (Eds.). 1994. Everglades: The Ecosystem and its Restoration. St. Lucie Press, Delray Beach, FL. 
Eadie, B.J., B.A. McKee, M.B. Lansing, J.A. Robbins, S. Metz, J.H. Trefry. 1994. Records of nutrient enhanced coastal ocean productivity in sediments from the Louisiana Continental Shelf. Estuaries 17: 754-765.

Ewe, S.M.L., and L.S.L. Sternberg. 2002. Seasonal water use by the invasive exotic, Schinus terebinthifolius. Oecologia 133:441-448.

Ewe, S.M.L., and L.S.L. Sternberg. 2003. Seasonal gas exchange characteristics of Schinus terebinthifolius in a native and disturbed upland community in Everglades National Park, Florida. Forest Ecology and Management 179:27-36.

Fogel, M.L., L.A. Cifuentes, D.J. Velinsky, and J.H. Sharp. 1992. Relationship of carbon availability in estuarine phytoplankton to isotopic composition. Marine Ecology Progress Series 82:291-300.

Fourqurean, J.W., S.P. Escorcia, W.T. Anderson, J.C. Zieman. 2005. Spatial and seasonal variability in elemental content $\delta^{13} \mathrm{C}$ and $\delta^{15} \mathrm{~N}$ of Thalassia testudinum from South Florida and its implications for ecosystem studies. Estuaries 28:447461.

Fourqurean, J.W., and M.B. Robblee. 1999. Florida Bay: a history of recent ecological changes. Estuaries 22:345-357.

Fourqurean, J.W., R.D. Jones, J.C. Zieman. 1993. Processes influencing water column nutrient characteristics and phosphorus limitation of phytoplankton biomass in Florida Bay, FL, USA: Inferences from spatial distributions. Estuarine, Coastal, and Shelf Science 36:295-314.

Fourqurean, J.W., G.V.N. Powell, and J.C. Zieman. 1992. Relationships between porewater nutrients and seagrasses in a subtropical carbonate environment. Marine Biology 114:57-65.

Fourqurean, J.W., and J.C. Zieman. 1992. Phosphorus limitation of primary production in Florida Bay, Evidence from C:N:P: ratios of the dominant seagrass, Thalassia testudinum. Limnology and Oceanography 37:162-171.

Francois, R., M.A. Altabet, and L.H. Burckle. 1992. Glacial to interglacial changes in surface nitrate utilization in the Indian sector of the Southern Ocean as recorded by sediment $\delta^{15} \mathrm{~N}$. Paleoceanography 7:589-606.

Gibson, P.J., J.N. Boyer, N.P. Smith. 2008. Nutrient mass flux between Florida Bay and the Florida Keys National Marine Sanctuary. Estuaries and Coasts 31:21-32.

Glibert, P.M., C.A. Heil, D. Hollander, M. Revilla, A. Hoare, J. Alexander, S. Murasko, 2004. Evidence for dissolved organic nitrogen and phosphorus uptake during a cyanobacterial bloom in Florida Bay. Marine Ecology Progress Series 280:73-83. 
Halley, R.B., and L.M. Roulier. 1999. Reconstructing the history of eastern and central Florida Bay using mollusk-shell isotope records. Estuaries 22:358-368.

Harrigan, P., J.C. Zieman, S.A. Macko. 1989. The base of nutritional support for the gray snapper (Lutjanus griseus): An evaluation based on a combined stomach content and stable isotope analysis. Bulletin of Marine Science 44:65-77.

Hodell, D.A., and C.L. Schelske. 1998. Production, Sedimentation, and isotopic composition of organic matter in Lake Ontario. Limnology and Oceanography 43:200-214.

Hollander, D.J. and J.A. McKenzie. 1991. $\mathrm{CO}_{2}$ control on carbon isotope fractionation during aqueous photosynthesis: a paleo- $\mathrm{pCO}_{2}$ barometer. Geology 19:929-932.

Huvane, J.K., and S.R. Cooper. 2001. Diatoms as indicators of environmental change in sediment cores from Northeastern Florida Bay. Bulletin of Marine Science 44:145-158.

Huvane, J.K. 2002. Modern diatom distributions in Florida Bay: A preliminary analysis. In: The Everglades, Florida Bay, and Coral Reefs of the Florida Keys: An Ecosystem Source Book. Eds: James W. Porter ad Karen G. Porter. CRC Press, Boca Raton pp. 478-495.

Lamb, K. 2006. Nitrogen cycling on coral reefs: A stable isotopic investigation of nutrient dynamics within the Florida Keys coral reef tract. Ph.D. Dissertation, University of Miami, 392 p.

Lamb, K, and P.K. Swart. 2008. The carbon and nitrogen isotopic values of particulate organic material from the Florida Keys: a temporal and spatial study. Coral Reefs 27:351-362.

Lapointe, B.E., P.J. Barile, and W.R. Matzie. 2004. Anthropogenic nutrient enrichment of seagrass and coral reef communities in the Lower Florida Keys: Discrimination of local versus regional nitrogen sources. Journal of Experimental Marine Biology and Ecology 308:23-58.

Lapointe, B.E., and M.W. Clark. 1992. Nutrient inputs from the watershed and coastal eutrophication in the Florida Keys. Estuaries 15:465-476.

Lapointe, B.E., D.A. Tomasco, and W.R. Matzie. 1994. Eutrophication and the trophic state classification of seagrass communities in the Florida Bay Keys. Bulletin of Marine Science 54:696-717.

Lavrentyev, P.J, H.A. Bootsma, T.H. Johngen, J.F. Cavaletto, W.S. Gardner. 1998. Microbial plankton response to resource limitation: insights from the community structure and seston stoichiometry in Florida Bay, USA. Marine Ecology Progress Series 165:45-57. 
Leichter, J.J., M.D. Stokes, S.J. Genovese. 2008. Deep water macroalgal communities adjacent to the Florida Keys reef tract. Marine Ecology Progress Series 365:123138.

Leichter, J.J., H.L. Stewart, S.L. Miller. 2003. Episodic nutrient transport to Florida coral reefs. Limnology and Oceanography 48:1394-1407.

Mahaffey, C., R.G. Williams, G.A. Wolff, W.T. Anderson. 2004. Physical supply of nitrogen to phytoplankton in the Atlantic Ocean. Global Biogeochemical Cycles 18:1034-1046

Mahaffey, C., R.G. Williams, G.A. Wolff, N. Mahowald, W.T. Anderson, M. Woodward. 2003. Biogeochemical signatures of nitrogen fixation in the eastern North Atlantic. Geophysical Research Letters 30:33-36.

Maie, N, C. Yang, T. Miyoshi, K. Parish, R. Jaffé. 2005. Chemical characteristics of dissolved organic matter in an oligotrophic subtropical wetland/estuarine ecosystem. Limnology and Oceanography 50:23-35

McIvor, C.C., J.A. Ley, R.D. Bjork. 1994. Changes in freshwater inflow from the Everglades to Florida Bay including effects on biota and biotic processes. In:

S.M. Davis and J.C. Ogden (Eds.) Everglades: The Ecosystem and its Restoration. St. Lucie Press, Delray Beach, FL.

McKenzie, J.A. 1985. Carbon isotopes and productivity in the lacustrine and marine environment. In: Chemical Processes in Lakes. ed. Werner Stumm. John Wiley and Sons: NewYork. 1985.

Mead, R.N. 2003. Organic matter dynamics in the Florida Coastal Everglades: a molecular marker and isotopic approach. Thesis ( $\mathrm{Ph}$. D.)--Florida International University, 306 pp

Millero, F., F. Huang, X. Zhu, X. Liu, and J. Zhang. 2001. Adsorption and desorption of phosphate on calcite and aragonite in seawater. Aquatic Geochemistry 7:33-56.

Minoura, K., K. Hoshino, T. Nakamura, E. Wada. 1997. Late-Pleistocene-Holocene paleoproductivity circulation in the Japan Sea: sea level control on $\delta^{13} \mathrm{C}$ and $\delta^{15} \mathrm{~N}$ records of sediment organic material. Palaeogeography, Plaeoclimatology, Palaeoecology 135:41-50.

Muller, A., and M. Voss. 1999. The paleoenvironments of coastal lagoons in the southern Baltic Sea, II. $\delta^{13} \mathrm{C}$ and $\delta^{15} \mathrm{~N}$ ratios of organic matter - sources and sediments. Palaeogeography, Plaeoclimatology, Palaeoecology 154:17-32. 
Nagel, E.D. 2004. Nitrogen fixation in benthic microalgal mats: An important, internal source of new nitrogen to benthic communities in Florida Bay. Masters Thesis, University of Maryland, 103 pp.

Nelson, T.A., H.R. Wanless, J.H. Trefry, W.J. Kang, S. Metz, C. Alvarez-Zarikian, T. Hood, P. Swart, G. Ellis, P. Blackwelder, L. Tedesco, C. Slouch, J.F. Pachut, M. O’Neal. 2002. Linkages between the South Florida peninsula and coastal zone: A sediment based history of natural and anthropogenic influences. In: The Everglades, Florida Bay, and Coral Reefs of the Florida Keys: An Ecosystem Source Book. Eds: J.W. Porter and K.G. Porter. CRC Press, Boca Raton pp. 415449.

Orem, W.H., C.W. Holmes, C. Kendall, H.E. Lerch, A.L. Bates, S.R. Silva, A. Boylan, M. Corum, M. Marot, C. Hedgman. 1999. Geochemistry of Florida Bay sediments: Nutrient history at five sites in eastern and central Florida Bay. Journal of Coastal Research 15:1055-1071.

Ostrom, N.E., S.A. Macko, D. Deibel, and R.J. Thompson. Seasonal variation in the stable carbon and nitrogen isotope biogeochemistry of a cold coastal environment. Geochimica et Cosmochimica Acta 61:2929-2942.

Peterson, B.J. and B. Fry. 1987. Stable isotopes in ecosystem studies. Annual Reviews in Ecological Systems 18:293-320.

Phlips, E.J., S. Badylak, T.C. Lynch. 1999. Blooms of the picnocyanobacterium Synechococcus in Florida Bay, a subtropical inner-shelf lagoon. Limnology and Oceanography 44:1166-1175.

Phlips, E.J., S. Badylak. 1996. Spatial variability in phytoplankton sanding crop and composition in a shallow tropical inner-shelf lagoon, Florida Bay, USA. Bulletin of Marine Science 58:203-216.

Phlips, E.J., T.C. Lynch, and S. Badylak. 1995. Chlorophyll $a$, tripton, color, and light availability in a shallow tropical inner-shelf lagoon, Florida Bay, USA. Marine Ecology Progress Series 127:223-234.

Robblee, M.B., T.R. Barber, P.R. Carlson, Jr., M.J. Durako, J.W. Fourqurean, L.K. Muehlstein, D. Porter, L.A. Yarbro, R.T. Zieman, J.C. Zieman. 1991. Mass mortality of the tropical seagrass Thalassia testudinum in Florida Bay (USA). Marine Ecology Progress Series 71:297-299.

Rolff, C. 2000. Seasonal variation in $\delta^{13} \mathrm{C}$ and $\delta^{15} \mathrm{~N}$ of size-fractionated plankton at a coastal station in the northern Baltic proper. Marine Ecology Progress Series 203:47-65. 
Rudnick, D.T., Z. Chen, D.L. Childers, J.N. Boyer, D.T. Fontaine. 1999. Phosphorus and nitrogen inputs to Florida Bay: The importance of the Everglades watershed. Estuaries 22:398-416.

Schubert, C.J. and S.E. Calvert. 2001. Nitrogen and carbon isotopic composition of marine and terrestrial organic matter in Arctic Ocean sediments: implications for nutrient utilization and organic matter composition. Deep Sea Research I 48:789810.

Shemesh, A., S.A. Macko, C.D. Charles, G.H. Rau. 1993. Isotopic evidence for reduced productivity in the glacial southern ocean. Science 262:407-410.

Sigman, D.M., M.A. Altabet, D.C. McCorkle, R. Francois, G.Fischer. 2000. The $\delta^{15} \mathrm{~N}$ of nitrate in the Southern Ocean: Nitrogen cycling and circulation in the ocean interior. Journal of Geophysical Research 105:19599-19614.

Sigman, D.M., M.A. Altabet, R. Francois, D.C. McCorkle. 1999. The isotopic composition of diatom-bound nitrogen in Southern Ocean sediments. Palaeoceanography 14:118-134.

Smith, T.J., J. H. Hudson, M.B. Robblee, G.V.N. Powell, P.J. Ishdale. 1989. Freshwater flow into Florida Bay; a historical reconstruction based on fluorescent banding in the coral Solenastrea bournoni. Bulletin of Marine Science 44:274-282.

Smith, N.P. 1998. Tidal and long-term exchanges through channels in the middle and upper Florida Keys. Bulletin of Marine Science 62:199-211.

Swart, P.K., G.F. Healy, R.E. Dodge, P. Kramer, J.H. Hudson, R.B. Halley, M.B. Robblee. 1996. The stable oxygen and carbon isotopic record from a coral growing in Florida Bay: a 160 year record of climatic and anthropogenic influence. Palaeogeography, Palaeoclimatology, Palaeoecology 123:219-237.

Swart, P.K., G. Healy, L. Greer, M. Lutz, A. Saeid, D. Anderegg, R.E. Dodge, D. Rudnick. 1999. The use of chemical records in coral skeletons to ascertain past environmental conditions in Florida Bay. Estuaries 22:384-397.

Struck, U., K.C. Emeis, M.Voss, and others. 2001. Biological productivity during sapropel S5 formation in the Eastern Mediterranean Sea: Evidence from stable isotopes of nitrogen and carbon. Geochimica et Cosmochimica Acta 65:32493266.

Szmant, A.M. and A. Forrester. 1996. Water column and sediment nitrogen and phosphorus distribution patterns in the Florida Keys, USA. Coral Reefs 15:21-41.

Teranes, J.L., and S. Bernasconi. 2000. The record of nitrate utilization and productivity limitation provided by $\delta^{15} \mathrm{~N}$ values in lake organic matter - A study of sediment 
trap and core sediments from Baldeggersee, Switzerland. Limnology and Oceanography 45:801-813.

Wainright, S.C. and B. Fry. 1994. Seasonal variation in the stable isotopic compositions of coastal marine plankton from Woods Hole, Massachusetts and Georges Bank. Estuaries 17:552-560.

Ward-Paige, C.A., M.J. Risk, O.A. Sherwood. 2005. Reconstruction of nitrogen sources on coral reefs: $\delta^{15} \mathrm{~N}$ and $\delta^{13} \mathrm{C}$ in gorgonians from the Florida Reef Tract. Marine Ecology Progress Series 296:155-163.

Waser, N.A., Z. Yu, K. Yin, B. Neilsen, P.J. Harrison, D. Turpin, S.E. Calvert. 1999. Nitrogen isotopic fractionation during a simulated diatom spring bloom: importance of N-starvation in controlling fractionation. Marine Ecology Progress Series 179:291-296.

Waser, N.A., W.G. Harrison, E.J.H. Head, B. Neilsen, V.A. Lutz, S.E. Calvert. 2000. Geographic variations in the nitrogen isotope composition of surface particulate nitrogen and new production across the North Atlantic Ocean. Deep Sea Research I 47:1207-1226.

Williams, C.J., J.N. Boyer, F.J. Jochem. 2009. Microbial activity and carbon, nitrogen, and phosphorus content in a subtropical seagrass estuary (Florida Bay): Evidence for limited bacterial use of seagrass production. Marine Biology 156:341-353.

Wu, J., S.E. Calvert, C.S. Wong. 1997. Nitrogen isotope variations in the subarctic northeast Pacific: relationships to nitrate utilization and trophic structure. Deep Sea Research I 44:287-314.

Zieman, J.C., S.A. Macko, A.L. Mills. 1984. Role of seagrasses and mangroves in estuarine food webs: Temporal and spatial changes in stable isotope composition and amino acid content during decomposition. Bulletin of Marine Science 35:380-392. 
CHAPTER 2

SPATIAL VARIABILITY IN FLORIDA BAY PARTICULATE ORGANIC MATTER COMPOSITION: COMBINING FLOW CYTOMETRY WITH STABLE ISOTOPE ANALYSES 


\subsection{ABSTRACT}

Long term management plans for restoration of natural flow conditions through the Everglades increase the importance of understanding potential nutrient impacts of increased freshwater delivery on Florida Bay biogeochemistry. Planktonic communities respond quickly to changes in water quality, thus spatial variability in community composition and relationships to nutrient parameters must be understood in order to evaluate future downstream impacts of modifications to Everglades hydrology. Here are presented initial results combining flow cytometry analyses of phytoplankton and bacterial populations (0.1-50 $\mu \mathrm{m}$ size fraction) with measurements of $\delta^{13} \mathrm{C}$ and $\delta^{15} \mathrm{~N}$ composition and dissolved inorganic nutrient concentrations to explore proxies for planktonic species assemblage compositions and nutrient cycling. Particulate organic material in the 0.1-50 $\mu \mathrm{m}$ size fraction was collected from five stations in Northeastern and Western Florida Bay to characterize spatial variability in species assemblage and stable isotopic composition. A dense bloom of the picocyanobacterium, Synechococcus elongatus, was observed at Western Florida Bay sites. Smaller Synechococcus sp. were present at Northeast sites in much lower abundance. Bacteria and detrital particles were also more abundant at Western Florida Bay stations than in the northeast region. The highest abundance of detritus occurred at Trout Creek, which receives freshwater discharge from the Everglades through Taylor Slough. In terms of nutrient availability and stable isotopic values, the S. elongatus population in the Western bay corresponded to low DIN $\left(0.5 \mu \mathrm{M} \mathrm{NH}_{4}{ }^{+} ; 0.2 \mu \mathrm{M} \mathrm{NO}_{3}{ }^{-}\right)$concentrations and depleted $\delta^{15} \mathrm{~N}$ signatures ranging from +0.3 to $+0.8 \%$, suggesting that the bloom supported high productivity 
levels through $\mathrm{N}_{2}$-fixation. The $\delta^{15} \mathrm{~N}$ values from the Northeast bay were more enriched $\left(+2.0\right.$ to $+3.0 \%$ ), characteristic of $\mathrm{N}$-recycling. The $\delta^{13} \mathrm{C}$ values were similar for all marine Florida Bay stations, ranging from -17.6 to $-14.4 \%$, yet were depleted at the mangrove ecotone station, Trout Creek (-25.5 to $-22.3 \%$ ). The difference in the isotopic values reflects differences in carbon sources. These findings imply that variations in resource availability and nutrient sources exert significant control over planktonic community composition, which is reflected by stable isotopic signatures.

\subsection{INTRODUCTION}

Florida Bay has been influenced by changes in the timing and volume of freshwater flow from the Everglades in the last half century as a result of extensive modification of the natural discharge patterns by water management infrastructure (Davis \& Ogden 1994, Rudnick et al. 1999). This has prompted researchers to explore the extent to which salinity levels in the bay have been affected by these changes (Huvane, 2002). Further, it is hypothesized that human alteration of the Everglades watershed in the last century facilitating agriculture and urbanization may have increased nutrient loads to downstream Florida Bay leading to unknown impacts on the ecosystem (Fourqurean et al. 1993, Boyer et al. 1999). In the same time frame, biotic and water quality parameters have changed significantly (Lapointe et al. 2002). Historically, Florida Bay was a shallow, optically clear lagoon characterized by low nutrient levels and populated by abundant seagrass communities. However, in recent decades significant declines have been observed in water clarity, hypersaline conditions have periodically developed during 
summer months (Boyer et al. 1999), and widespread die-off events have occurred in the seagrass communities (Zieman et al. 1989, Fourqurean et al. 1993), coincident with phytoplankton blooms (Robblee et al. 1991, Butler et al. 1995, Phlips \& Badylak 1996). Causal mechanisms behind this shift in biotic communities remain the focus of ongoing study; however, the trigger for phytoplankton blooms is not fully understood (Richardson \& Zimba 2002).

Given long term management plans to restore more natural flow conditions through the Everglades, a key concern is the extent to which nutrients passing through or originating from the Everglades impact Florida Bay. Restored flows may alter the forms, amount, and temporal distribution of dissolved nutrients delivered to the bay. Planktonic communities respond quickly due to high population turnover rates and the tight association with water quality. In turn, the structure of these planktonic communities can have significant effects on biogeochemical cycles of nutrients (Lavrentyev et al. 1998). Yet, while much attention in Florida Bay has focused on changes in seagrass abundance and distribution (Zieman et al. 1989, Anderson \& Fourqurean 2003, Fourqurean et al. 2005), aspects of the composition and community dynamics of particulate organic matter (POM) remain poorly understood.

Several studies have taken steps toward characterizing Florida Bay’s phytoplankton community applying cell counting and pigment extraction techniques, demonstrating the bay is extremely variable in terms of both species diversity and biomass (Phlips \& Badylak 1996, Lavrentyev et al. 1998, Phlips et al. 1999, Richardson \& Zimba, 2002). Cyanobacteria, diatoms, and dinoflagellates have been identified as dominant organisms (Phlips \& Badylak 1996), but relative population abundances of 
several species in each group vary widely both spatially and temporally (Richardson \& Zimba, 2002). Lavrentyev et al. (1998) characterized the microbial plankton community with respect to resource limitation with a short term bay-wide survey, dividing the bay into three regions based on community structure and elemental stoichiometry. The North-central region of Florida Bay contained the highest cyanobacteria abundance (Lavrentyev et al. 1998). Physical restriction of tidal exchange between this interior zone and the surrounding oceanic environments enhances potential for accumulation of cyanobacterial biomass by increasing water residence times, while euryhaline cyanobacteria species are unaffected by periodic hypersaline conditions (Phlips et al. 1999).

Understanding of the biogeochemical connections between nutrient resources and population dynamics within the phytoplankton and bacterial components of POM is conspicuously absent in the literature. Isotopic-enrichment tracer techniques assessing utilization of organic nitrogen $(\mathrm{N})$ substrates during a cyanobacteria bloom event has shown in one instance that cyanobacterial blooms in Central Florida Bay are associated with high dissolved organic nutrient availability, whereas areas dominated by microflagellate and diatom communities are dependent upon inorganic nutrient resources (Glibert et al. 2004). The utility of natural isotopic abundance measurements to assess biogeochemical coupling between nutrient resources and planktonic communities has not been well explored. It is possible that bulk samples of the 0.1-50 $\mu \mathrm{m}$ POM fraction collected at sites characterized by different water quality parameters and nutrient availability will have distinct isotopic fingerprints based on species composition 
differences, or may reflect relative nutrient utilization between varying $\mathrm{N}$-sources (nitrate $\left(\mathrm{NO}_{3}{ }^{-}\right)$versus ammonium $\left.\left(\mathrm{NH}_{4}{ }^{+}\right)\right)$and nitrogen verses carbon limitation.

Here I present initial results combining flow cytometry analyses of phytoplankton and bacterial populations with natural abundance carbon and nitrogen isotopic signatures to explore proxies for biotic assemblage characteristics. Flow cytometry represents an advantage over traditional fluorescence microscopy and HPLC pigment analysis in that it allows efficient and objective analysis of large numbers of particles, with the facility to distinguish organic living and non-living particles (Moreira-Turcq \& Martin 1998). However, limitations in the numbers of pigments analyzed restrict taxonomic resolution as compared to other methods (Veldhuis \& Kraay 2000). Procedures coupling flow cytometry sorters with pyrolysis mass spectrometry for in-line analysis are currently under development (Minor \& Nallanthamby 2004; Pel et al. 2004), however at present sorted sample volumes are insufficient to perform $\delta^{15} \mathrm{~N}$ analyses, and isotopic values can only be obtained for $\delta^{13} \mathrm{C}$.

In this approach, flow cytometry is used to distinguish bacteria, cyanobacteria, eukaryotic phytoplankton, and detritus, allowing a broad view of POM composition at endmember locations in terms of Florida Bay nutrient and salinity gradients. The composition of POM is then compared with isotopic measurements. Further characterization and exploration of size-fractionated isotopic signatures advances understanding of phytoplankton, microbial, and biogeochemical dynamics in the system. 


\subsection{METHODS}

\subsubsection{Setting}

Florida Bay consists of a series of shallow basins ( $<3 \mathrm{~m}$ depth) separated hydrologically by a network of subtidal mudbanks and mangrove islands which restrict water mixing between basins and attenuate both tidal amplitude and current. Freshwater runoff, comparatively rich in dissolved inorganic nitrogen (DIN) and poor in soluble reactive phosphorus (SRP), enters this hydrologically complex system primarily in Northeastern Florida Bay through the Taylor Slough and the C-111 basin. Saline ocean water, comparatively depleted in DIN and enriched in SRP, enters across the western boundary with the Gulf of Mexico and through numerous tidal channels crossing the Florida Keys (Boyer et al. 1999). Interaction between these inflows and limitations on the bay's mixing regime serve to generate gradients in both salinity and nutrient availability across the bay. Salinity increases from the freshwater-affected northeastern region to the south and west to reach marine strength (36\%), with seasonal periods of hypersalinity (40-80\%) in restricted interior basins (Boyer et al. 1999). Nutrient gradients are evident in changing DIN:SRP ratios, which are considered an index of phytoplankton nutrient limitation, from northeast to southwest Florida Bay (Boyer et al. 1999). Long-term monitoring revealed little seasonality in consistently high DIN:SRP ratios in the eastern bay, indicating potentially continuous phosphorus $(\mathrm{P})$ limitation (Boyer et al. 1999, Fourqurean et al. 1993). Western Florida Bay DIN:SRP ratios are over three times lower and more variable than those in the northeastern region, implying fluctuations between $\mathrm{N}$ and $\mathrm{P}$ limitation, due not only to lower DIN concentrations in the 
western bay region than in the east, but also because SRP periodically supplied through mixing from the Gulf of Mexico (Boyer et al. 1999).

\subsubsection{Sampling Locations and Collection}

In November 2003, a "snapshot" of samples was collected at geographic endmember sites in the northeastern and western Florida Bay (Figure 2.1). Trout Creek (Station 5) represented a freshwater discharge influenced northeastern site (salinity 4.2\%o), while Duck Key (Station 4) and South Nest Key (Station 3) were marine northeast Florida Bay sites (salinity 24.5\%). Ninemile Bank (Station 2) and Sprigger Bank (Station 1) were representative of full seawater salinity western Florida Bay

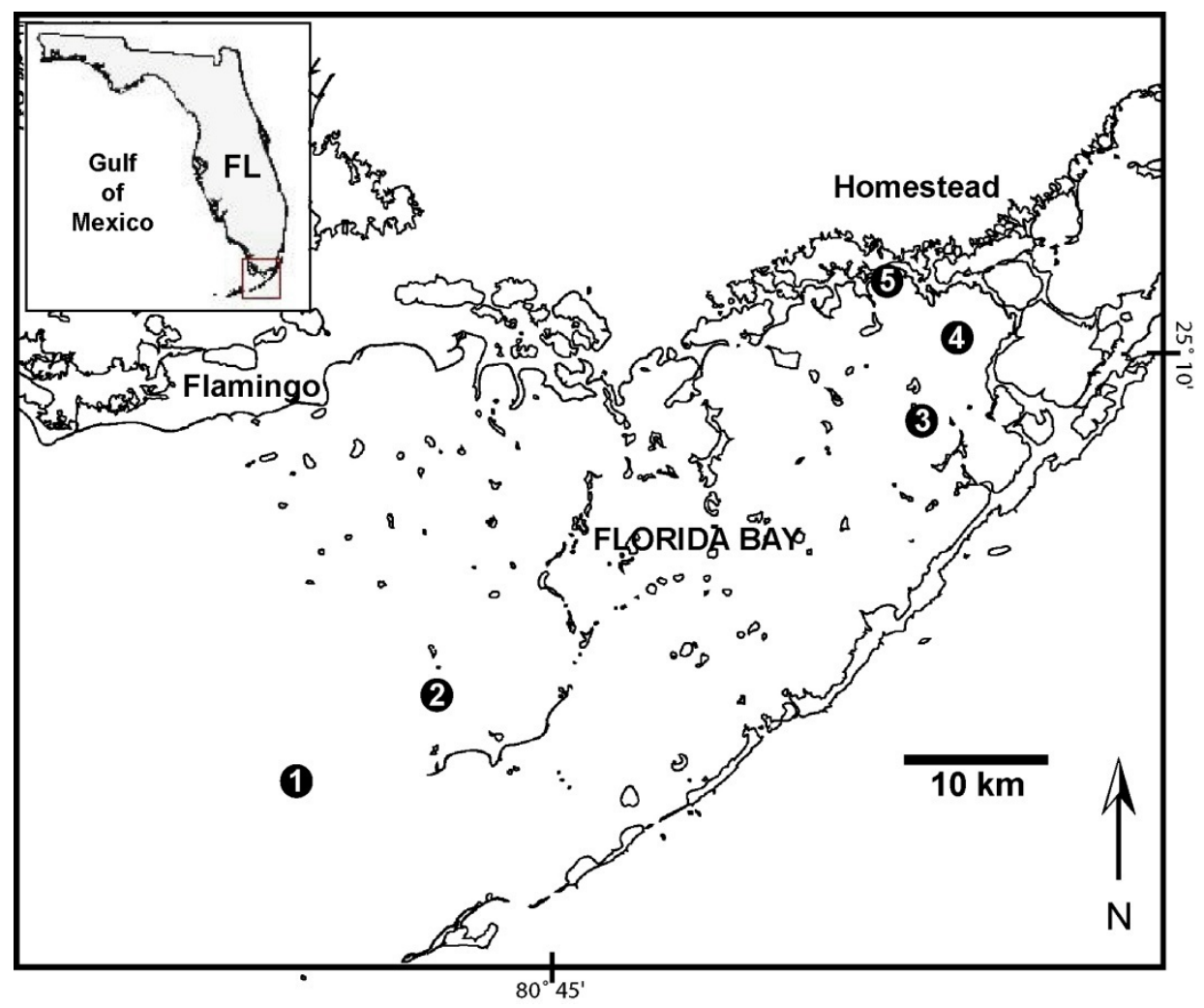

Figure 2.1 Map of Florida Bay, showing sampling locations in Western Florida Bay at Sprigger Bank (1) and Ninemile Bank (2), in Northeastern Florida Bay at South Nest Key (3) and Duck Key (4), and near the Taylor Slough Everglades outflow at Trout Creek (5). 
locations (salinity 35.5\%). Three sets of water samples were collected at each site after first passing though a $50 \mu \mathrm{m}$ Nitex screen to exclude larger size classes of zooplankton, phytoplankton, and detritus. Two replicate samples were collected at each station and preserved with formalin (final conc. 1\%) for cytometric analysis. Water samples for nutrient analyses $(30 \mathrm{ml})$ were syringe filtered with $0.45 \mu \mathrm{m} \mathrm{GF} / \mathrm{F}$ Whatman filters.

Finally, $1 \mathrm{~L}$ samples were collected for stable isotopic analysis of the $0.1-50 \mu \mathrm{m}$ POM fraction. All samples were kept in the dark and refrigerated at $5^{\circ} \mathrm{C}$ until time of analysis, which occurred within 3 days of sample collection. Salinity was measured using a digital Orion Temp/Salinity Meter.

\subsubsection{Flow Cytometry Analyses}

Heterotrophic bacteria and phytoplankton in the 0.1-50 $\mu \mathrm{m}$ POM fraction were counted on a Becton Dickinson FACSort flow cytometer equipped with an argon laser (488 nm). For each particle, two light scatter (side angle light scatter and forward light scatter) and three fluorescence signals were recorded on a 4-decades log scale. All data were analyzed using Win MDI 2.8 (Trotter 2000) flow cytometric analysis software to define populations by logical gating and generate plots illustrating 50000 events (particle detections).

A DNA staining procedure was used to enumerate heterotrophic bacteria (Marie et al. 1997). A $500 \mu \mathrm{L}$ sample aquilot was incubated with $25 \mu \mathrm{L}$ RNAase $\left(0.1 \mathrm{~g} \mathrm{~L}^{-1}, 1: 1\right.$ mixture of RNAase A \& B) for 30 minutes at $37^{\circ} \mathrm{C}$, followed by the addition of $20 \mu \mathrm{L}$ of SYBR Green I staining $\left(10^{-5}\right.$ dilution of commercial stock, Molecular Probes, Eugene, OR) in the presence of $30 \mathrm{mM}$ potassium citrate. SYBR DNA fluorescence was recorded 
in both the green FL1 $(535 \pm 15 \mathrm{~nm})$ and red FL3 $(>650 \mathrm{~nm})$ fluorescence channels, DNA clusters of bacteria were counted by logical gating from both FL1 vs FL3 and SSC vs FL1 dot plots, and histograms with gate borders set to minima in population frequency distribution. Measured sample volumes for estimates of bacterial abundance (cells ml ${ }^{-1}$ ) were calculated from measurement times (30 seconds) based on weight calibration of flow rates $\left(1 \mu \mathrm{s} \mathrm{s}^{-1}\right.$; Jochem 2001).

For bulk phytoplankton samples, $1 \mathrm{ml}$ of each replicate sample was analyzed without staining, as phytoplankton pigments exhibit detectable autofluorescence following laser excitation (Hofstraat et al. 1994). Phytoplankton populations were differentiated using chlorophyll autofluorescence, detected in the red FL3 $(>650 \mathrm{~nm})$ fluorescence channel, phycoerythrin autofluorescence, detected in the orange FL2 (575 \pm $25 \mathrm{~nm}$ ) fluorescence channel, and side angle light scatter was measured (SSC channel) for proxy analysis of relative cell size. Cell concentrations were calculated based on measurement times (150 seconds) and weight-calibrated flow rates.

\subsubsection{Isotopic Analyses}

Water samples (1L) were vacuum-filtered through Whatman Anodisc membrane filters $(0.1 \mu \mathrm{m}$ pore size $)$. These filters are aluminum oxide matrix, and thus do not influence carbon and nitrogen stable isotope signatures (Bertoni, 1997). Filters were oven dried $\left(70^{\circ} \mathrm{C}\right)$ and powdered. Powdered filter samples were analyzed following standard Elemental Analyzer Isotope Ratio Mass Spectometry (EA-IRMS) methods on a Finnigan MAT Delta C Isotope Ratio Mass Spectrometer at the Stable Isotope Laboratory of the Southeast Environmental Research Center. $\delta^{13} \mathrm{C}$ analyses were conducted after 
acidifying vials with approximately $5 \mathrm{ml} 1 \mathrm{~N} \mathrm{HCl}$ for carbonate removal. $\delta^{15} \mathrm{~N}$ analyses were conducted on raw filter material. Reproducibility of nitrogen isotope analyses was $\pm 0.2 \%$, while carbon reproducibility was $\pm 0.05 \%$, based on duplicate analyses of both samples and multiple internal laboratory standards.. All isotopic values are reported using standard delta $(\delta)$ notation:

$$
\delta=\left[\left(R_{\text {sample }} / R_{\text {standard }}\right)-1\right] \times 1000
$$

Where $R$ is the isotopic ratio, i.e. ${ }^{15} \mathrm{~N} /{ }^{14} \mathrm{~N}$ or ${ }^{13} \mathrm{C} /{ }^{12} \mathrm{C}$ in either sample or standard.

\subsubsection{Nutrient Analyses}

Surface water filtrates from each site were analyzed for nitrate + nitrite $\left(\mathrm{NO}_{\mathrm{x}}{ }^{-}\right)$, nitrite $\left(\mathrm{NO}_{2}^{-}\right)$, ammonium $\left(\mathrm{NH}_{4}^{+}\right)$, and SRP with an Alpkem model RFA 300 water autoanalyzer set to 4 channel simultaneous flow. Nitrate $\left(\mathrm{NO}_{3}{ }^{-}\right)$concentrations were calculated as $\mathrm{NO}_{\mathrm{x}}{ }^{-}-\mathrm{NO}_{2}{ }^{-}$. These samples were compared to long term water quality data sets provided by the SERC-FIU Water Quality Monitoring Network.

\subsection{RESULTS}

Eukaryotic algae (EUK) and four distinct populations of cyanobacteria (numbered 1-4) were differentiated through logical gating of bivariate flow cytometry analysis plots (Figure 2.2). Each point on the individual plots represents a single particle detection, thus darker areas indicate higher particle densities. Groups of eukaryotic algae and cyanobacteria are shown within ellipses because they are difficult to distinguish visually in monochromatic plots. Spatial variability in assemblage and population abundance is 


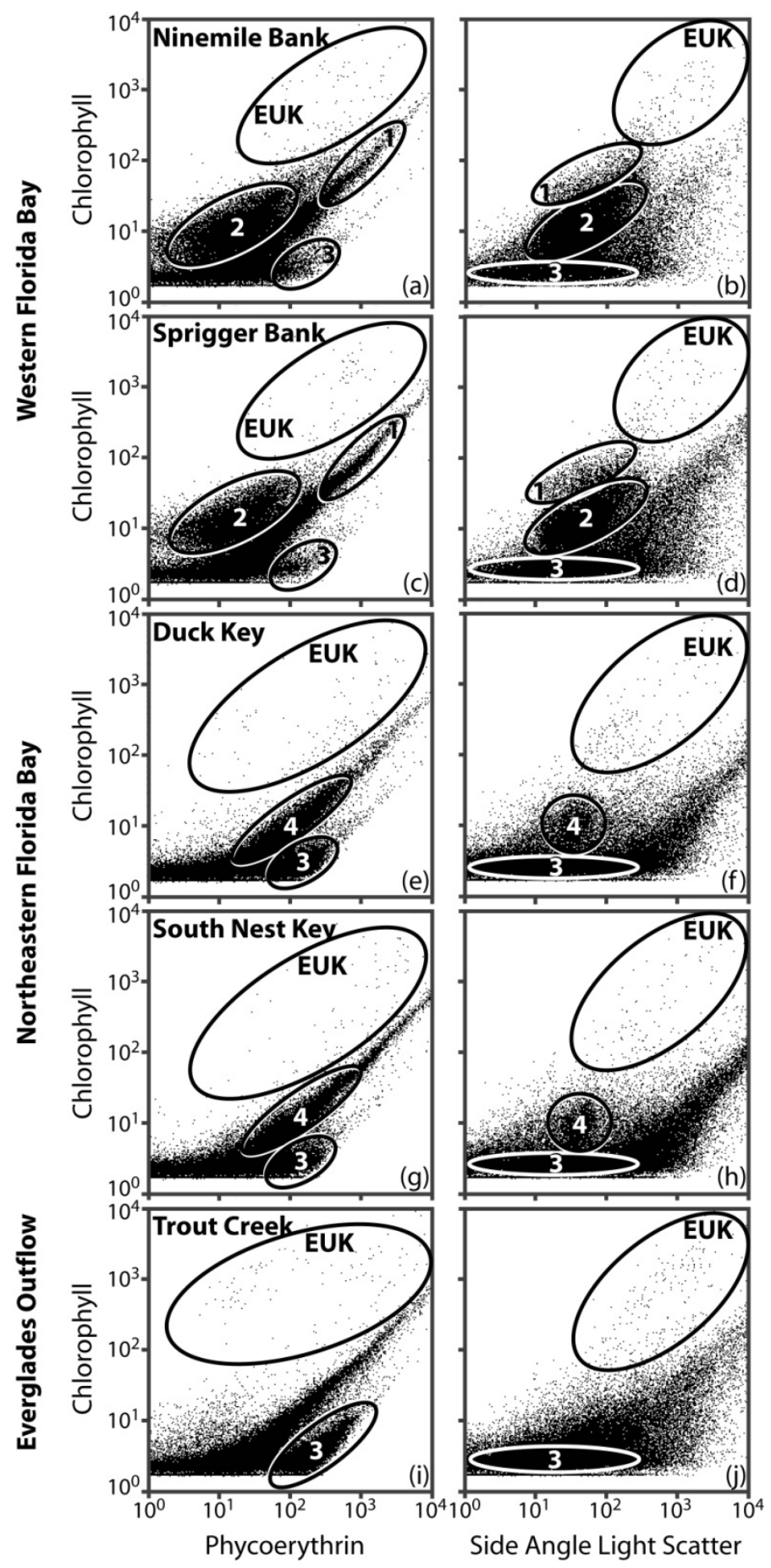

Figure 2.2 Flow cytometry analyses of Florida Bay phytoplankton collected at five sampling locations in Western (a-d) and Northeastern (e-h) Florida Bay, and proximal to the Everglades outflow (i-j). 50000 events are displayed after acquisition in log mode. The left side plots from each site display phycoerythrin (FL2) against chlorophyll (FL3); the right side plots show Side Angle Light Scatter (relative cell-size proxy) with chlorophyll. All axes are on a 4 decade log scale. Eukaryotic algae (EUK) and 4 distinct cyanobacterial populations are shown (circled and numbered 1-4), as determined using logical gating between the plot pairs from each site. Particles not included in definable populations of cells are considered detrital particles. 
Table 2.1 Mean and S.D. of phytoplankton and bacteria population abundances determined by logical gating (Win MDI; Trotter 1994-2000) for samples collected during the Nov. 2003 Florida Bay snapshot POM sampling. All values are cells $\mathrm{ml}^{-1} * 10^{3}$

\begin{tabular}{|c|c|c|c|c|c|c|c|c|}
\hline Site & $\begin{array}{c}\text { Total } \\
\text { Phytoplank. }\end{array}$ & Eukaryotes & Cyanobact. 1 & $\begin{array}{l}\text { S. elongatus* } \\
\text { Cyanobact. } 2\end{array}$ & $\begin{array}{c}\text { Syn. sp.** } \\
\text { Cyanobact. } 3\end{array}$ & Cyanobact. 4 & Detritus & Bacteria \\
\hline Sprigger Bank & $660.3 \pm 65.2$ & $1.7 \pm 0.2$ & $46.7 \pm 1.1$ & $532.9 \pm 25.0$ & $81.5 \pm 40.3$ & & $627.6 \pm 47.9$ & 2058.1 \\
\hline Ninemile Bank & $934.8 \pm 87.8$ & $3.5 \pm 0.8$ & $79.5 \pm 13.9$ & $801.9 \pm 56.3$ & $66.8 \pm 22.2$ & & $655.1 \pm 220.0$ & 2412.1 \\
\hline South Nest Key & $33.7 \pm 5.5$ & $0.8 \pm 0.1$ & & & $8.6 \pm 3.9$ & $32.1 \pm 4.90$ & $261.6 \pm 59.6$ & 854.1 \\
\hline Duck Key & $166.6 \pm 38.9$ & $3.4 \pm 0.4$ & & & $80.0 \pm 75.2$ & $37.4 \pm 11.3$ & $245.9 \pm 71.8$ & 623.5 \\
\hline Trout Creek & $520.7 \pm 81.6$ & $4.6 \pm 1.8$ & & & $522.0 \pm 81.2$ & & $1157.0 \pm 457.5$ & 1431.8 \\
\hline
\end{tabular}

*Synechococcus elongatus.

**Synechococcus sp. 
evident (Table 2.1). The highest abundances were seen in the low chlorophyll, low phycoerythrin population, Synechococcus elongatus (Figure 2.2; Cyanobacteria 2), with $801.9 \pm 56.3 \times 10^{3}$ and $532.9 \pm 25.0 \times 10^{3}$ cells ml $^{-1}$ present only at the western Florida Bay sites (Ninemile Bank and Sprigger Bank, respectively). S. elongatus is known to form blooms in central and western Florida Bay (Lavrentyev et al. 1998; Phlips et al. 1999, Glibert et al. 2004). A second population of Synechococcus sp, distinguished by higher phycoerythrin and a smaller size (Figure 2.2; Cyanobacteria 3), was present at all stations, but with higher densities at the northeastern sites and with highest abundance $\left(522.0 \pm 81.2 \times 10^{3}\right.$ cells ml $\left.^{-1}\right)$ at Trout Creek. Cyanobacteria 4 , similar in size to $S$. elongatus, but with higher phycoerythrin content, were present at much lower abundance at northeast Florida Bay sites $\left(32.1 \pm 4.90 \times 10^{3}\right.$ cells ml $^{-1}$ at South Nest; $37.4 \pm 11.3 \times$ $10^{3}$ cells ml $^{-1}$ at Duck Key). Eukaryotic algae were present at all stations in very low abundance, with the largest population at the Trout Creek site $\left(4.6 \pm 1.8 \times 10^{3}\right.$ cells ml$\left.^{-1}\right)$. High abundances of autofluorescing detrital particles were evident at all stations (Table 2.1); however, the largest detrital signal occurred in the Everglades freshwater discharge exiting Taylor Slough at Trout Creek. The west Florida Bay stations had threefold higher detritus concentrations than the northeastern sites. Bacterial communities also differed spatially between western and northeastern Florida Bay (Figure 2.3). Up to five populations of bacteria exhibiting different DNA content were evident at all marine Florida Bay stations, but were less distinct at Trout Creek. Two additional populations with higher red fluorescence were abundant at western bay region, present at northeastern sites in much lower abundance; these may represent Prochlorococcus sp., or additional bacterial populations. 

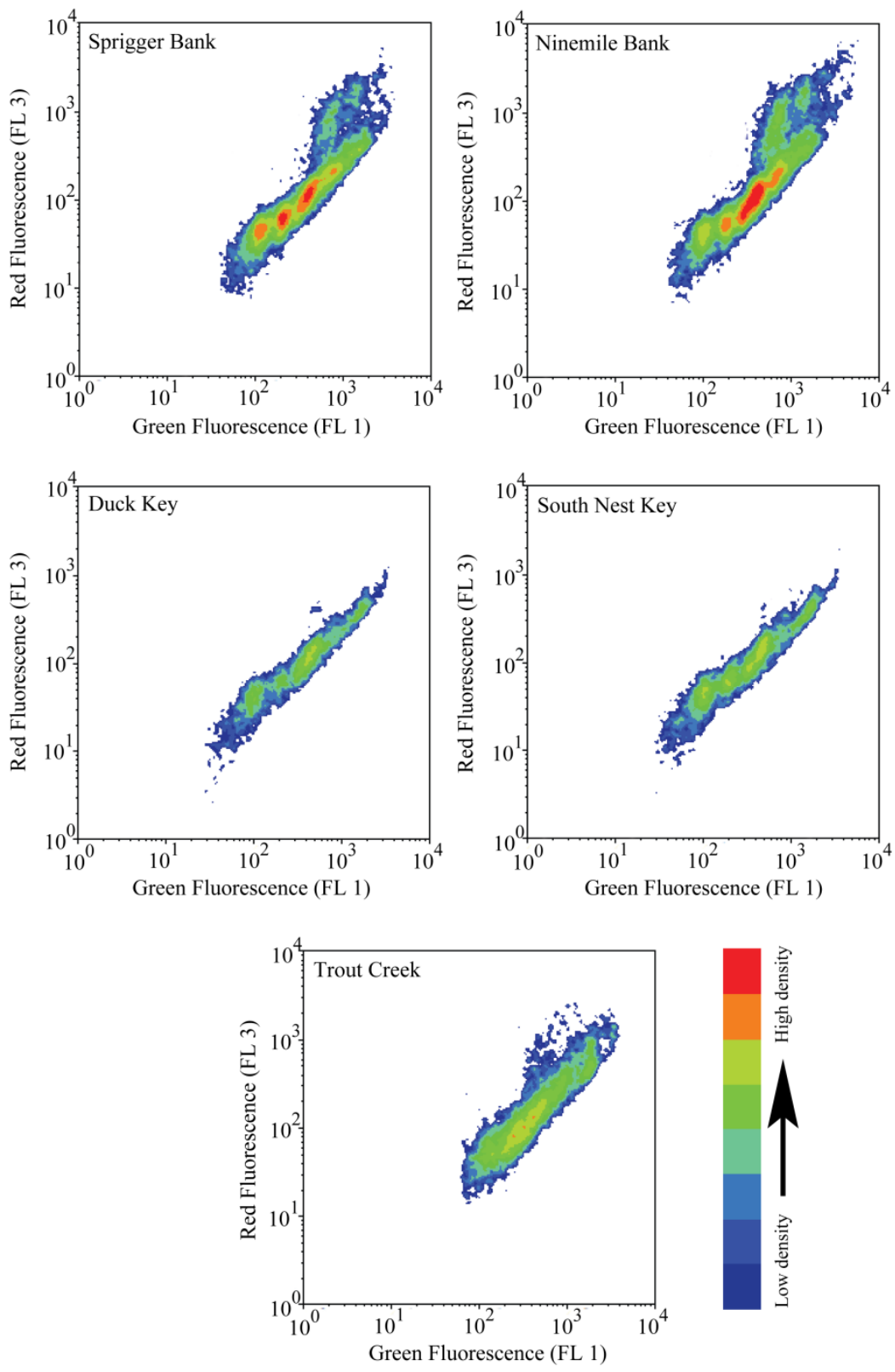

Figure 2.3 Flow cytometry analyses of November, 2003, Florida Bay surface water bacteria samples after DNA staining with SYBR Green. Green fluorescence (FL1) vs red fluorescence (FL3) are shown for all sites on a 4 decade log scale.

The maximum bacteria concentrations were measured at Ninemile Bank $\left(2.412 \times 10^{6}\right.$ cells $\mathrm{ml}^{-1}$ ), while much lower bacteria concentrations were found at northeastern sites $\left(0.623 \times 10^{6}\right.$ cells ml $^{-1}$ at Duck Key; $0.854 \times 10^{6}$ cells ml $^{-1}$ at South Nest Key $)$. Trout 
Creek, in the mangrove ecotone, exhibited higher bacterial abundance than the open water northeast Florida Bay stations (Table 2.1).

Carbon and nitrogen isotopic signatures demonstrate differences between geographic endmembers of Florida Bay environmental gradients (Figure 2.4). The Trout Creek location exhibited the most depleted carbon values (-25.3\%o to $-22.3 \%)$, whereas the open water locations in both western and northeastern Florida Bay were slightly more enriched, ranging from $-17.6 \%$ to $-14.4 \%$. $\delta^{15} \mathrm{~N}$, however, differed between west and northeast Florida Bay. At northeastern sites, nitrogen isotopic signatures were $+2.0 \%$ to $+3.0 \%$, while more depleted values were evident at western bay stations, where a minimum $\delta^{15} \mathrm{~N}$ value of $+0.3 \%$ was observed. The variation in POM nitrogen isotopic signal is coincident with a large difference in inorganic nitrogen concentrations between endmember locations (Figure 2.4). The western sites had over an order of magnitude lower ammonium $\left(\mathrm{NH}_{4}{ }^{+}\right)$concentrations $\left(9.5 \mathrm{vs} 0.5 \mu \mathrm{M} \mathrm{NH}_{4}{ }^{+}\right.$, northeast and west sites, respectively) and nearly an order of magnitude lower nitrate $\left(\mathrm{NO}_{3}{ }^{-}\right)$levels (1.2 vs $0.2 \mu \mathrm{M}$ $\mathrm{NO}_{3}{ }^{-}$, northeast and west).

\subsection{DISCUSSION}

High spatial heterogeneity in the 0.1-50 $\mu \mathrm{m}$ POM fraction across Florida Bay was reflected by differences in community composition, relative significance of individual sub-populations, total phytoplankton and bacterial abundances, and detritus loads. These differences are not unexpected, as noted in previous studies of the Florida Bay planktonic community (Phlips \& Badylak, 1996, Phlips et al. 1999, Lavrentyev et al. 1998, Glibert et 


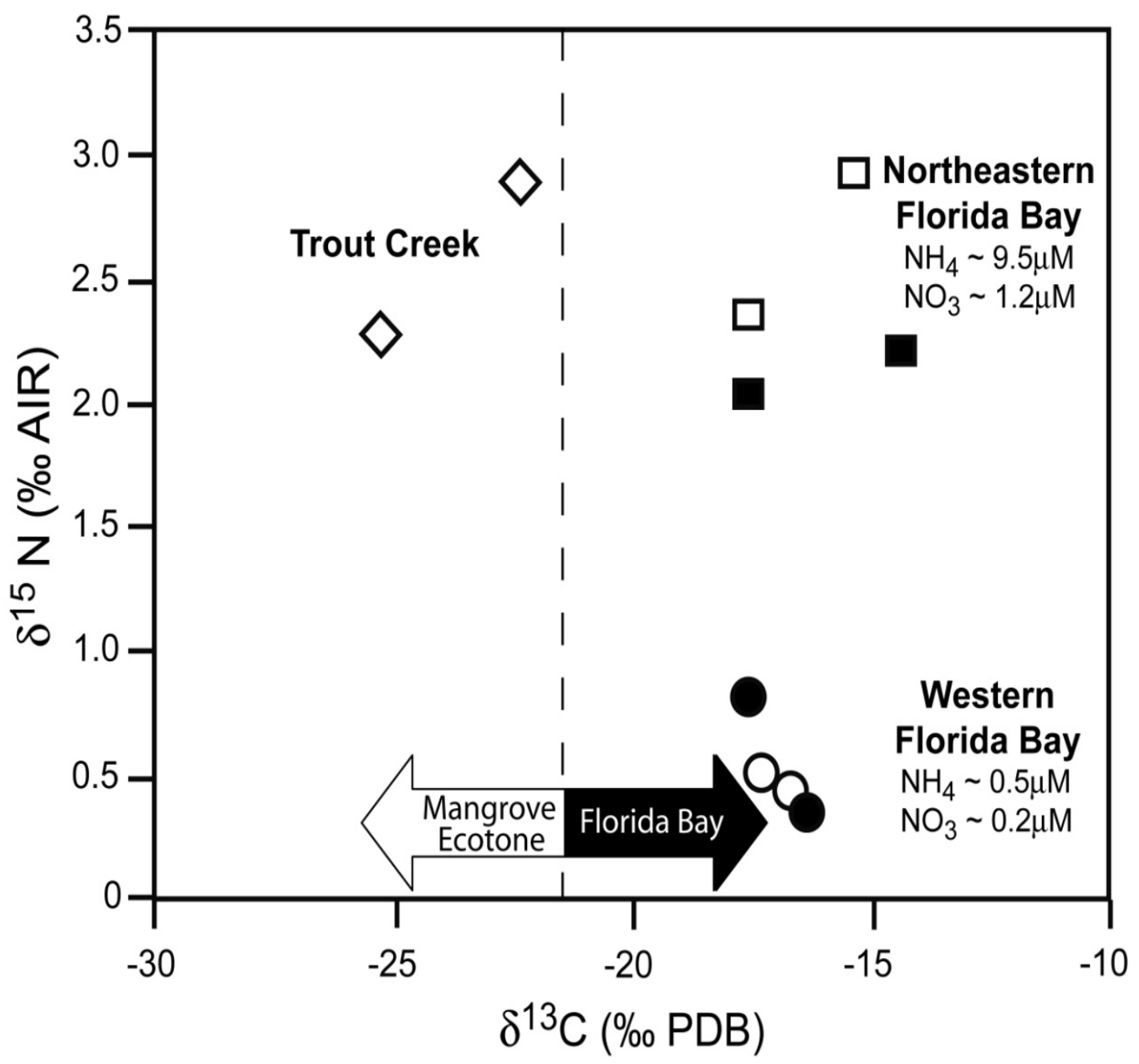

Figure 2.4 Stable isotope signals in $0.1-50 \mathrm{~mm}$ POM collected in November 2003. Everglades outflow: Trout Creek $(\diamond)$; Northeast Florida Bay: South Nest Key ( $\square$ ), Duck Key ( $\square$ ); Western Florida Bay: Ninemile Bank (०), and Sprigger Bank (•).

al. 2004, Frankovich et al. 2006). Indeed, the physical and chemical variability of the system and the isolated nature of the various basins of Florida Bay certainly lead to the high level heterogeneity in planktonic communities. Populations of Synechococcus $s p$. were present throughout the bay (Figure 2.2; Cyanobacteria 3), however in higher abundances in northeastern Florida Bay than in the west. In fact, the highest abundance of Synechococcus sp. was found at Trout Creek, the lowest salinity site, proximal to Everglades' freshwater outflow. The dominance of this species in the northeastern, 
strongly P-limited region of Florida Bay (Fourqurean et al. 1993) supports the conclusions of Stockner (1988) that Synechococcus sp. is a superior competitor for phosphorus, coupling high SRP affinity with rapid uptake velocities and the facility for luxury uptake. In addition, this genus is very well adapted to changing environmental conditions, exhibiting a broad range of salinity tolerance, the ability to saturate photosynthesis and growth at very low irradiance, and potential to assimilate dissolved organic nutrients (Stockner, 1988, Phlips et al. 1989, Luo \& Mitsui 1994, Lavrentyev et al. 1998, Glibert et al. 2004). In contrast, Cyanobacteria 4, with higher chlorophyll, and slightly larger-sized cells, were absent from Trout Creek and present in lower abundance in the northeastern bay as compared to the western stations. This may indicate that Cyanobacteria 4 are less tolerant of low salinities and less competitive in nutrient acquisition than typical Florida Bay Synechococcus sp.

The most abundant population found throughout Florida Bay in this study was Synechococcus elongatus, a larger, phycocyanin-rich strain of the genus exhibiting lower phycoerythrin than the population previously discussed (Phlips et al. 1999). The $S$. elongates population represented 80 and $84 \%$ of the phytoplankton numerical abundance in western Florida Bay at Sprigger and Ninemile Banks, respectively. These proportions are somewhat lower than those observed by Glibert et al. (2004) during an extensive bloom in November 2002 where S. elongatus represented over 99\% of the phytoplankton abundance in western and north-central Florida Bay. Further, S. elongatus represented over $90 \%$ of phytoplankton biovolume during fall blooms between 1993 and 1997, though no directly comparable numerical abundance values were given (Phlips et al. 1999). There are several possible explanations for apparent differences between the 
relative proportions of S. elongatus measured in this and prior studies, the most obvious being a smaller bloom in 2003 relative to previous years. Also, values reported here may represent either the early or late period in terms of bloom development, and might not correspond to peak bloom abundance. Furthermore, the maximum abundances noted by both Phlips et al. (1999) and Glibert et al. (2004) were located at sites in the north central region of Florida Bay, rather than the western boundary zone described here; thus it is possible that the high abundances of S. elongatus found in western Florida Bay in the present study were coincident with much greater populations that were not sampled at more interior locations. Long term chlorophyll A datasets indicate peak concentrations in Whipray Basin, North-central Florida Bay, exceeded those in the western region and were reached in October 2003. Concentrations in both regions had begun to decline in November (SERC-FIU Water Quality Monitoring Network).

The dominance of S. elongatus at the western Florida Bay endmember has interesting implications in terms of both nutrient availability and stable isotopic signatures. Depleted $\delta^{15} \mathrm{~N}$ isotopic signatures in the western bay during the S. elongatus bloom in November 2003 differed markedly from nitrogen isotopic values of 4.2\% recorded during a similar bloom in November 2002 (Glibert et al. 2004). Isotopic depletion during a cyanobacterial bloom opposes the expectation that high primary productivity and surface nutrient utilization induces isotopic enrichment, as has been reported in many studies of oceanic and lacustrine POM (Ostrom et al. 1997; Altabet et

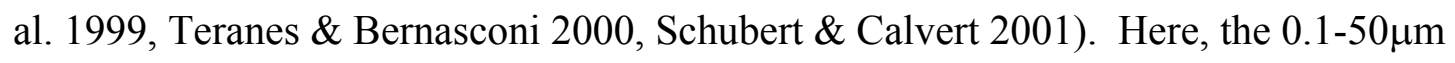
POM had $\delta^{15} \mathrm{~N}$ values characteristic of nitrogen fixing bacteria/cyanobacteria, which are habitually near $0 \%$ in terms of $\delta^{15} \mathrm{~N}$, reflecting the isotopic signature of atmospheric 
nitrogen (Gu \& Alexander 1993, Liu et al. 1996, Mahaffey et al. 2003). The ${ }^{15} \mathrm{~N}-$ depletion may suggest that nitrogen fixation represents a significant nutrient source for this population, which is consistent with several studies of potential aerobic $\mathrm{N}$-fixation in Synechococcus species, including S. elongatus (Duerr, 1981, Phlips et al. 1989, Luo \& Matsui 1994, Phlips \& Badylak 1996, Church, 2005). Although nitrogenase activity had been documented in Synechococcus sp. cultures in the past (i.e. Duerr, 1981), until recently, unicellular cyanobacteria were not considered important contributors to oceanic nitrogen fixation. However, recent molecular-based techniques identifying nitrogenase gene expression have suggested an active role in nitrogen fixation for these groups (Falcón et al. 2004, Church 2005). DIN concentrations approximately an order of magnitude lower than in the eastern bay and low DIN:SRP ratios in western Florida Bay, indicative of N-limitation of phytoplankton growth, might provide competitive advantage to nitrogen fixing cyanobacteria in this region. Similar results have been documented in benthic microalgae. Nagel (2004) measured nitrogen fixation along a west-east transect of Florida Bay at the sediment-water interface, finding orders of magnitude higher Nfixation in the $\mathrm{N}$-limited western end of the transect in comparison to eastern sites.

Other components of the $0.1-50 \mu \mathrm{m}$ POM that may contribute to the differences in the nitrogen isotopic signal between Florida Bay regions are the heterotrophic bacteria and particulate detritus concentrations observed. Western Florida Bay exhibited much higher abundances in both these particulate categories. While specific populations of the bacterial component were not identified, two clusters displaying high red fluorescence were abundant in the western bay, but were only present at very low abundances at the northeastern open marine sites. It would seem that the very high detritus and bacterial 
abundance in western Florida Bay are related to the S. elongatus bloom; however, since samples amalgamating all components of the $0.1-50 \mu \mathrm{m}$ POM were analyzed for their isotopic signature, it is impossible to separate the relative importance of each component in terms of $\delta^{15} \mathrm{~N}$ value differences between regions. Yet, it is generally accepted that microbial degradation of autochthonous particulate organic material in marine systems tends to enrich the residual POM by remineralizing isotopically depleted $\mathrm{NH}_{4}{ }^{+}$(Liu et al. 1996); however, the overall POM signal presented here is depleted in the region corresponding to the higher bacterial and detrital abundances.

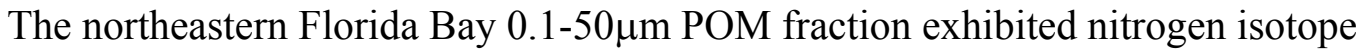
signatures more characteristic of nutrient recycling in estuarine waters. However, at $+2.0 \%$ to $+3.0 \%$, these signatures are depleted relative to values in reported many estuaries (and very depleted relative to values measured in highly eutrophic settings; Middleburg \& Nieuwenhuize 2001), which can vary widely, depending on trophic status and anthropogenic nitrogen impacts. Estuarine POM $\delta^{15} \mathrm{~N}$ values range from $+4 \%$ to $>+20 \%$, although few, if any, of these estuaries represent the oligotrophic regime characteristic of Florida Bay (Montoya et al. 1991, Rolff \& Elmgren 2000, Middleburg \& Nieuwenhuize 2001). Nitrogen isotopic values from oligotrophic open-ocean settings tend to reflect the isotopic signals of upwelled nitrate $(\approx+5.0 \%)$ altered in some cases by enrichment due to nutrient utilization or denitrification (Miyake \& Wada 1967, Liu \& Kaplan 1989; Schubert \& Calvert 2001). In northeastern Florida Bay, isotopically light POM may reflect the assimilation of nitrogen discharged through the Everglades outflow. Uptake of a relatively depleted nitrogen source delivered by Everglades freshwater outflow is supported by the similarity between the low salinity mangrove ecotone Trout 
Creek signal and the two northeast bay open water sites. Similar to differences noted at the western stations, the depleted POM signal in northeast Florida Bay is much more depleted than nitrogen isotopic values measured by Glibert et al. (2004) in Little Madeira Bay, November 2004 (+8.63\%). Little Madeira Bay is located within $5 \mathrm{~km}$ of all northeastern locations sampled in the work presented here. The differences between these studies (November 2002 versus November 2003) reflect the variable nature of the system in terms of water quality, nutrient sources, and storm induced perturbations. The potential that the comparatively depleted estuarine isotopic signal reported here indicates uptake of an isotopically light nitrogen source may be supported by the fact that ammonium concentrations were nearly tenfold higher than nitrate concentrations at the northeastern sites in November 2003. The $\delta^{15} \mathrm{~N}$ signatures of phytoplankton incorporating remineralized ammonium are more depleted (Checkley \& Entzeroth 1985), and ${ }^{15} \mathrm{~N}$-tracer experiments confirmed that $\mathrm{NH}_{4}{ }^{+}$is generally assimilated preferentially over $\mathrm{NO}_{3}{ }^{-}$in most phytoplankton (Montoya et al. 1991, Maguer et al. 2000, Velinsky \& Fogel 1999). High $\mathrm{NH}_{4}{ }^{+}$concentrations in northeastern Florida Bay suggest $\mathrm{NH}_{4}{ }^{+}$as the predominant nitrogen source for primary production, causing observed $\delta^{15} \mathrm{~N}$ signatures in this region. Nitrification of an isotopically light ammonium source might also produce an isotopically depleted nitrate pool, which could be assimilated by phytoplankton (Cifuentes et al. 1989). Because inorganic phosphorus concentrations are persistently limiting in this region, it is unlikely that primary productivity increases generate high enough nitrogen uptake rates to deplete available pools, and thus no isotopic enrichment of photosynthetic autotrophs is evident. 
Carbon isotopic signatures did not differ between northeastern and western Florida Bay, suggesting similar carbon acquisition mechanisms and/or relative carbon limitation between plankton communities in different regions of the bay. The $\delta^{13} \mathrm{C}$ values of $-17.6 \%$ to $-14.4 \%$ fell within the published range of values from estuarine phytoplankton (Gearing et al. 1984, Velinsky \& Foge 1999, Rau et al. 2001). Although the more enriched values may indicate some degree of carbon limitation or a shift toward a carbon concentration mechanism $(\mathrm{CCM})$ whereby bicarbonate $\left(\mathrm{HCO}_{3}{ }^{-}\right)$is used as a carbon source. $\mathrm{HCO}_{3}{ }^{-}$becomes the dominant dissolved inorganic carbon (DIC) species available under conditions of increasing $\mathrm{pH}$ related to high photosynthetic uptake of dissolved $\mathrm{CO}_{2}$. A number of studies have demonstrated that many microalgal genera, including Synechococcus, are capable of switching to a CCM that facilitates assimilation of $\mathrm{HCO}_{3}{ }^{-}$in response to increasing $\mathrm{HCO}_{3}{ }^{-}$concentrations and dissolved $\mathrm{CO}_{2}$ limitation. (Badger \& Andrews 1982, Mayo et al. 1986, Fogel et al. 1992, Popp et al. 1998, Matsuda et al. 2001, Rau et al. 2001). It is reasonable then, that the cyanobacterial populations at both northeastern and western Florida Bay stations employ this mechanism under carbon stress. Yet, high photosynthetic rates assumed inherent in cyanobacterial blooms are not reflected by $\mathrm{POM} \delta{ }^{13} \mathrm{C}$ enrichment under carbon limitation and decreases in isotopic discrimination. Open connectivity between western Florida Bay and the Gulf of Mexico, and diurnal tidal exchange may serve to maintain DIC availability at a similar level to that in northeastern Florida Bay even though the northeast exhibits much lower productivity levels. An alternative explanation for the relatively enriched $\delta^{13} \mathrm{C}$ values of marine Florida Bay stations is the fact that seagrass detritus may represent either a significant component of the particulate detritus, or may represent a carbon source used 
by the microbial community. Seagrass $\delta^{13} \mathrm{C}$ signatures are more enriched than those typical for $\mathrm{C}_{3}$ plants, varying seasonally between $-13.5 \%$ and $-5.2 \%$, likely attributable to an active $\mathrm{CCM}$ and $\mathrm{HCO}_{3}{ }^{-}$uptake (Fourqurean et al. 2005, Anderson \& Fourqurean 2003). Seagrass associated carbon, either in the form of microbially released dissolved $\mathrm{CO}_{2}$ or as a particulate detritus component of the $0.1-50 \mu \mathrm{m}$ POM, would serve to generate the more enriched carbon isotopic values evident at marine stations in Florida Bay.

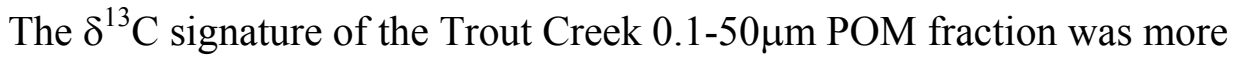
isotopically depleted then those at open water marine sites. This ${ }^{13} \mathrm{C}$ depletion may reflect different carbon sources between the brackish mangrove ecotone and open marine systems, perhaps indicating that the Trout Creek outflow is influenced by dissolved or particulate organic carbon associated with terrestrial sources (Kendall \& McDonnell 1998). This contention is supported not only by the station's proximity to the mangrove ecotone of the southern Everglades, but also by a more than fourfold higher concentration of detritus at the Trout Creek site, compared to the open marine sites in northeastern Florida Bay. The carbon isotopic signatures evident at the station imply that a large component of the detritus is likely of mangrove origin with some autochthonous inputs from the water column community.

\subsection{CONCLUSION}

The isotopic composition of POM in near-shore and estuarine settings can provide important information about ambient environmental conditions, biotic community 
structure, and biogeochemical cycling within the system. This information may be used to infer changes in primary productivity and water quality parameters in increasingly environmentally sensitive coastal settings. Combining flow cytometry with stable isotopic analyses provides unique insight into ecological controls on carbon and nitrogen isotopic signatures of POM, improving interpretations. In many marine settings, carbon and nitrogen isotopic signatures have been interpreted in terms of surface nutrient utilization and productivity levels, yet here we present data from a cyanobacterial bloom showing nitrogen isotopic depletion, rather than enrichment. This isotopic depletion has implications regarding the importance of biologically fixed nitrogen as a nutrient source during bloom events, particularly in nitrogen-limited marine environments. Further work examining other indicators of $\mathrm{N}$-fixation, such as nitrogenase enzymatic assays or mesocosm experimentation measuring uptake of isotopically labeled $\mathrm{N}_{2}$ gas, is needed to elucidate the role fixed nitrogen plays in South Florida coastal environments.

The spatial variability evident in Florida Bay planktonic species assemblages, detritus concentrations, and corresponding isotopic compositions suggests that bulk POM isotopic values combining all size fractions may not be easily attributed to external nutrient forcings without closer examination. More extensive size-fractionated POM sampling, distributed geographically and over longer term time-series development, is necessary to more fully understand carbon and nitrogen cycling within the South Florida coastal zone. Further work examining temporal variability in planktonic assemblages and corresponding isotopic compositions, taken in conjunction with water quality variables and the isotopic composition of dissolved inorganic nutrient compounds will greatly 
enhance understanding of nitrogen and carbon cycling in Florida Bay and adjacent marine systems.

This chapter was published in 2006:

Evans, S.L, W.T.Anderson, and F.J. Jochem. 2006. Spatial variability in Florida Bay particulate organic matter composition: combining flow cytometry with stable isotope analyses. Hydrobiologia 569:151-165. 


\section{LITERATURE CITED}

Altabet, M.A., C. Pilskaln, R. Thunell, C. Pride, D. Sigman, F. Chavez, R. Francois, 1999. The nitrogen isotope biogeochemistry of sinking particles from the margin of the Eastern North Pacific. Deep Sea Research I 46:655-679.

Anderson, W.T., \& J.W. Fourqurean, 2003. Intra- and Interannual variability in seagrass carbon and nitrogen stable isotopes from South Florida, a preliminary study. Organic Geochemistry 34:185-194.

Badger, M.R., \& T.J. Andrews, 1982. Photosynthesis and inorganic carbon usage by the marine cyanobacterium, Synechococcus sp.. Plant Physiology 70:251-261.

Bertoni, R. 1997. The routine use of Anodisc filters with automatic $\mathrm{CHN}$ analyzers. Memorie del'Istituto Italiano di Idrobiologia 56:157-161.

Boyer, J.N., J.W. Fourqurean, \& R.D. Jones, 1999. Seasonal and long term trends in the water quality of Florida Bay (1989-1997). Estuaries 22:417-430.

Checkley, D.M. Jr, \& L.C. Entzeroth, 1985. Elemental and isotopic fractionation of carbon and nitrogen by marine, planktonic copepods and implications to the marine nitrogen cycle. Journal of Plankton Research 7:553-568.

Church, M.J., B.D. Jenkins, D.M. Karl, \& J.P. Zehr, 2005. Vertical distributions of nitrogen-fixing phylotypes at Stn. ALOHA in the oligotrophic North Pacific Ocean. Aquatic Microbial Ecology 38:3-14.

Cifuentes, L.A., M.L. Fogel, J.R. Pennock, \& J.H. Sharp, 1989. Biogeochemical factors that influence the stable nitrogen isotope ratio of dissolved ammonium in the Delaware estuary. Geochimica et Cosmochimica Acta 53:2713-2721.

Davis, S.M. \& J.C. Ogden (Eds.), 1994. Everglades: The Ecosystem and its Restoration. St. Lucie Press, Delray Beach, FL.

Duerr, Eirik. 1981. Aerobic nitrogen fixation by two unicellular marine cyanobacteria (Synechococcus spp.). Ph. D. Dissertation, University of Miami, Miami, FL.

Falcón, LI, E.J. Carpenter, F. Cipriano, B. Bergman, \& D.G. Capone, 2004. $\mathrm{N}_{2}$-fixation by unicellular bacterioplankton from the Atlantic and Pacific oceans: phylogeny and in situ rates. Applied Environmental Microbiology 70: 765-770.

Fogel, M.L., L.A. Cifuentes, D.J. Velinsky, \& J.H. Sharp, 1992. Relationship of carbon availability in estuarine phytoplankton to isotopic composition. Marine Ecology Progress Series 82:291-300. 
Fourqurean, J.W., S.P. Escorcia, W.T. Anderson, \& J.C. Zieman, 2005. Spatial and seasonal variability in elemental content, $\delta^{13} \mathrm{C}$, and $\delta^{15} \mathrm{~N}$ of Thalassia testudinum from South Florida and its implications for ecosystem studies. Estuaries 28:447-460.

Fourqurean, J.W., \& M.B. Robblee, 1999. Florida Bay: A history of recent ecological changes. Estuaries 22:345-357.

Fourqurean, J.W., R.D. Jones, \& J.C. Zeiman, 1993. Processes influencing water column nutrient characteristics and phosphorus limitation of phytoplankton biomass in Florida Bay, Fl, USA: Inferences from spatial distributions. Estuarine, Coastal, and Shelf Science 36:295-314.

Frankovich, T.A., E.E. Gaiser, J.C. Zieman, A.H. Wachnicka. 2006. Spatial and temporal distributions of epiphytic diatoms growing on Thalassia testudinum Banks ex. Konig: Relationships to water quality. Hydrobiologia 569:259-271.

Gearing, J.N., P.J. Gearing, D.T. Rudnick, A.G. Roquejo, \& M.J. Hutchins, 1984. Isotopic variability of organic carbon in a phytoplankton-based, temperate estuary. Geochimica et Cosmochimica Acta 48:1089-1098.

Glibert, P.M., C.A. Heil, D. Hollander, M. Revilla, A. Hoare, J. Alexander, \& S. Murasko, 2004. Evidence for dissolved organic nitrogen and phosphorus uptake during a cyanobacterial bloom in Florida Bay. Marine Ecology Progress Series 280:73-83.

Gu, B., \& V. Alexander, 1993. Estimation of $\mathrm{N}_{2}$-fixation based on differences in the natural abundance of ${ }^{15} \mathrm{~N}$ among freshwater $\mathrm{N}_{2}$-fixing and non- $\mathrm{N}_{2}$-fixing algae. Oecologia 96:43-48.

Hofstraat, J.W., W.J.M van Zeijl, M.E.J. de Vreeze, J.C.H. Peeters, L. Peperzak, F. Colijn, \& T.W.M. Rademaker, 1994. Phytoplankton monitoring by flow cytometry. Journal of Plankton Research 16:1197-1224.

Huvane, J.K., 2002. Modern diatom distributions in Florida Bay: A preliminary analysis. In: The Everglades, Florida Bay, and Coral Reefs of the Florida Keys: An Ecosystem Source Book. Eds: James W. Porter ad Karen G. Porter. CRC Press, Boca Raton pp. 478-495.

Jochem, F.J., 2000. Probing the physiological state of phytoplankton at the single-cell level. Scientia Marina 64:183-195.

Jochem, F.J., 2001. Morphology and DNA content of bacterioplankton in the northern Gulf of Mexico: Analysis by epifluorescence microscopy and flow cytometry. Aquatic Microbial Ecology 25:179-194. 
Kendall, C, \& J. McDonnell, 1998. Isotope Tracers in Catchment Hydrology. Elsevier, New York. 872 pgs.

Lapointe, B.E., W.R. Matzie, \& P.J. Barile, 2002. Biotic phase shifts in Florida Bay and Fore Reef communities of the Florida Keys: Linkages with historical freshwater flows and nitrogen loading from Everglades runoff. In: The Everglades, Florida Bay, and Coral Reefs of the Florida Keys: An Ecosystem Source Book. Eds: James W. Porter \& Karen G. Porter. CRC Press, Boca Raton pp. 629-648.

Lavrentyev, P.J, H.A. Bootsma, T.H. Johngen, J.F. Cavaletto, \& W.S. Gardner, 1998. Microbial plankton response to resource limitation: insights from the community structure and seston stoichiometry in Florida Bay, USA. Marine Ecology Progress Series 165:45-57.

Liu, K.K., M.J. Su, C.R. Hsueh, \& G.C. Gong, 1996. The nitrogen isotopic composition of nitrate in the Kuroshio water northeast of Taiwan: evidence for nitrogen fixation as a source of isotopically light nitrate. Marine Chemistry 54:273-292.

Liu, K.K., \& I.R. Kaplan, 1989. The eastern tropical Pacific as a source of super ${ }^{15} \mathrm{~N}$ enriched nitrate in seawater off southern California. Limnology and Oceanography $34: 820-830$.

Luo, Y.H., \& A. Mitsui, 1994. Hydrogen production from organic substrates in an aerobic nitrogen-fixing marine unicellular cyanobacterium, Synechococcus sp. strain Miami BG043511. Biotechnology and Bioengineering 44:1255-1260.

Maguer, J., S. L'Helguen, \& P. Le Corre, 2000. Nitrogen uptake by phytoplankton in a shallow water tidal front. Estuarine, Coastal, and Shelf Science 51:349-357

Mahaffey, C., R.G. Williams, G.A. Wolff, N. Mahowald, W.T. Anderson, \& M. Woodward, 2003. Biogeochemical signatures of nitrogen fixation in the eastern North Atlantic. Geophysical Research Letters 30:33-36.

Marie, D., F. Partensky, S. Jacquet, \& D. Vaulot, 1997. Enumeration and cell cycle analysis of natural populations of marine picoplankton by flow cytometry using the nucleic acid stain SYBR Green I. Applied Environmental Microbiology 63:186-193.

Matsuda, Y., T. Hara, \& B. Coleman, 2001. Regulation of the induction of bicarbonate uptake by dissolved $\mathrm{CO}_{2}$ in the marine diatom, Phaeodactylum tricornutum. Plant, Cell, and Environment 24:611-620.

Mayo, W.P., T.G Williams, D.G. Birch, \& D.H. Turpin, 1986. Photosynthetic adaptation by Synechococcus leopoliensis in response to exogenous dissolved inorganic carbon. Plant Physiology 80:1038-1040. 
Middelburg, J.J., \& J. Nieuwenhuize, 2001. Nitrogen isotope tracing of dissolved inorganic nitrogen behaviour in tidal estuaries. Estuarine, Coastal, and Shelf Science 53:385-391.

Miyake, Y. \& E.Wada, 1967. The abundance ratio of ${ }^{15} \mathrm{~N} /{ }^{14} \mathrm{~N}$ in marine environments. Records of Oceanographic Works in Japan 9: 37-53.

Montoya, J.P., S.G. Harrigan, \& J.J. McCarthy, 1991. Rapid, storm-induced changes in the natural abundance of ${ }^{15} \mathrm{~N}$ in a planktonic ecosystem, Chesapeake Bay, USA. Geochimica et Cosmochimica Acta 55:3627-3638.

Moreira-Turcq, P., \& J.M. Martin, 1998. Characterization of fine particles by flow cytometry in estuarine and coastal Arctic waters. Journal of Sea Research 39:217226.

Ostrom, N.E., S.A. Macko, D. Deibel, \& R.J. Thompson, 1997. Seasonal variation in the stable carbon and nitrogen isotope biogeochemistry of a cold coastal environment. Geochimica et Cosmochimica Acta 61:2929-2942.

Phlips, E.J., S. Badylak, \& T.C. Lynch, 1999. Blooms f the picoplanktonic cyanobacterium Synechococcus in Florida Bay, a subtropical inner-shelf lagoon. Limnology and Oceanography 44:1166-1175.

Phlips, E.J., \& S. Badylak, 1996. Spatial variability in phytoplankton standing crop and composition in a shallow tropical inner-shelf lagoon, Florida Bay, USA. Bulletin of Marine Science 58:203-216.

Phlips, E.J., C. Zemen, \& P. Hansen, 1989. Growth, photosynthesis, nitrogen fixation and carbohydrate production by a unicellular cyanobacterium, Synechococcus sp. (Cyanophyta). Journal of Applied Phycology 1:137-145.

Popp, B.N., E.A. Laws, R.R. Bidigare, J.E. Dore, K.L. Hanson, \& S.G. Wakeham, 1998. Effect of phytoplankton cell geometry on carbon isotopic fractionation. Geochemica et Cosmochemica Acta 62:69-77.

Rau, G.H., F.P. Chavez, \& G.E. Friederich, 2001. Plankton ${ }^{13} \mathrm{C} /{ }^{12} \mathrm{C}$ variations in Monterey Bay, California: evidence of non-diffusive inorganic carbon uptake by phytoplankton in an upwelling environment. Deep Sea Research I 48:79-94.

Richardson, L.L., \& P.V. Zimba, 2002. Spatial and temporal patterns of phytoplankton in Florida Bay: Utility of algal accessory pigments and remote sensing to assess bloom dynamics. In: The Everglades, Florida Bay, and Coral Reefs of the Florida Keys: An Ecosystem Source Book. Eds: James W. Porter \& Karen G. Porter. CRC Press, Boca Raton pp. 461-478. 
Robblee, M.B., T.R. Barber, P.R. Carlson, Jr., M.J. Durako, J.W. Fourqurean, L.K. Muehlstein, D. Porter, L.A. Yarbro, R.T. Zieman, J.C. Zieman. 1991. Mass mortality of the tropical seagrass Thalassia testudinum in Florida Bay (USA). Marine Ecology Progress Series 71:297-299.

Muehlstein, D. Porter, L.A. Yarbro, R.T. Zieman, \& J.C. Zieman, 1991. Mass mortality of the tropical seagrass Thalassia testudinum in Florida Bay (USA). Marine Ecology Progress Series 71:297-299.

Nagel, E.D. 2004 Nitrogen fixation in benthic microalgal mats: An important, internal nutrient source of new nitrogen to benthic communities in Florida Bay. Masters Thesis, University of Maryland, $103 \mathrm{pp}$.

Rolff, C., \& R. Elmgren, 2000. Use of riverine organic matter in plankton foodwebs of the Baltic Sea. Marine Ecology Progress Series 197:81-101.

Rudnick, D.T., Z. Chen, D.L. Childers, J.N. Boyer, \& T.D. Fontaine, III, 1999. Phosphorus and nitrogen inputs to Florida Bay: The importance of the Everglades watershed. Estuaries 22:398-416.

Schubert, C.J. \& S.E. Calvert, 2001. Nitrogen and carbon isotopic composition of marine and terrestrial organic matter in Arctic Ocean sediments: implications for nutrient utilization and organic matter composition. Deep Sea Research I 48:789-810.

Stockner, J.G., 1988. Phototrophic picoplankton: an overview from marine and freshwater ecosystems. Limnology and Oceanography 33:765-775.

Teranes, J.L., \& S. Bernasconi, 2000. The record of nitrate utilization and productivity limitation provided by $\delta^{15} \mathrm{~N}$ values in lake organic matter - A study of sediment trap and core sediments from Baldeggersee, Switzerland. Limnology and Oceanography 45:801-813.

Veldhuis, M.J.W., \& G.W. Kraay, 2000. Application of flow cytometry in marine phytoplankton research: current applications and future perspectives. Scientia Marina 64:121-134.

Velinsky, D.J., \& M.L. Fogel, 1999. Cycling of dissolved and particulate nitrogen and carbon in the Framvaren Fjord, Norway: stable isotopic variations. Marine Chemistry 67:161-180.

Zieman, J.C., J.W. Fourqurean, \& R.L. Iverson, 1989. Distribution, abundance, and production of seagrass and macroalgae in Florida Bay. Bulletin of Marine Science 44:579-601. 
CHAPTER 3

SPATIAL AND TEMPORAL VARIABILITY IN THE ISOTOPIC COMPOSITION OF PARTICULATE ORGANIC MATERIAL: SOURCES, CONTROLS, AND EPISODIC CHANGE 


\subsection{ABSTRACT}

Understanding the variability in carbon and nitrogen isotopic composition of particulate organic material (POM) in the coastal zone is crucial to studies of biogeochemical processes in marine environments. This is particularly true in South Florida as long term plans for restoration of natural flow conditions through the Everglades increase the importance of understanding baseline characteristics of the system in terms of nutrient cycling and biogeochemistry. Additionally, while many studies apply bulk POM isotopic and elemental compositional data to ecological problems, there is little consideration given to the components integrated in bulk particulate signatures. In this study, isotopic compositions $\left(\delta^{13} \mathrm{C}\right.$ and $\left.\delta^{15} \mathrm{~N}\right)$ of three size fractions of particulate organic matter $(0.1-50 \mu \mathrm{m}, 50-150 \mu \mathrm{m}$, and $>150 \mu \mathrm{m})$ from ten locations in Florida Bay and the Florida Keys National Marine Sanctuary were determined on a quarterly basis over a 2-year period in order to examine seasonality and spatial variability in isotopic values of POM size components. Significant differences were observed among both size classes and locations in terms of isotopic values and seasonal patterns. $\delta^{13} \mathrm{C}$ values varied between -29.59 and $-7.4 \%$ while $\delta^{15} \mathrm{~N}$ values ranged from +1.44 to $+8.52 \%$. Isotopic enrichment-depletion cycles varied on a quarterly basis; however, patterns differed among locations related to local hydrodynamic influences. Larger amplitude changes were found in Florida Bay sampling locations as compared to sites along the Florida Keys Reef Tract. 


\subsection{INTRODUCTION}

The combined measurement of carbon and nitrogen natural abundance isotopic ratios, expressed as $\delta^{13} \mathrm{C}$ and $\delta^{15} \mathrm{~N}$, of suspended particulate organic matter (POM) have proven useful in aquatic biogeochemistry and ecology to assess the origin (terrestrial, freshwater, or marine reservoir) and fate of POM (Gearing 1988, Altabet 1988, Matson and Brinson 1990, Thornton and McManus 1994, Cifuentes et al. 1996, Sigleo and Macko 2002). Carbon and nitrogen isotopic values have also been applied in efforts to gauge surface nutrient utilization by autotrophs and clarify metabolic pathways (Goericke et al. 1994, Altabet 2001, Savoye et al. 2003), to study C and N cycles (Altabet et al. 1999, Battle et al. 2000) and to describe food web trophic relationships (Fry and Sherr 1984, Peterson 1999). Most of these studies, however, focused either on bulk organic material (undifferentiated plankton tow collection, bulk filtrations, total surface sediments, etc.), or on higher level invertebrate or vertebrate consumers (Rau et al. 1990). There have been relatively few studies characterizing $\delta^{13} \mathrm{C}$ and $\delta^{15} \mathrm{~N}$ in discrete size classes of POM with the intent to differentiate between isotopic signals associated with various taxonomic and trophic groups integrated in bulk measurements. Given the variability in production mechanisms/nutrient acquisition, as well as trophic and feeding differences occurring across plankton size classes (Rau et al. 1990, Wainright and Fry 1994, Rolff 2000, Sato et al. 2006, Loick et al. 2007), there is considerable potential for isotopic heterogeneity between size fractional isolates of bulk POM. Further, considering rapid turnover rates and the tight association between planktonic communities and water quality, POM can potentially impact ecological function and biogeochemical properties 
of the coastal zone. Thus, better understanding of processes and interactions between particulate components is essential to more complete understanding of the shallow coastal interface between terrestrial and marine systems.

Estuarine POM is composed of several components of different origins, including in situ autocthonous plankton, higher plant detritus transported by rivers or sloughs, and local submerged aquatic vegetation and re-suspended organic sediment. Stable carbon isotopic composition has been conventionally used to discriminate between autochthonous marine (comparatively enriched $\delta^{13} \mathrm{C}$ ) and allocthonous terrestrial (more depleted $\delta^{13} \mathrm{C}$ ) organic carbon sources (Coffin et al. 1994). Nitrogen isotopic composition also often shows clear difference between terrestrial and marine origins (Peters et al. 1978, Mariotti et al. 1984, McClelland and Valiela 1998, Umezawa et al. 2002), and has been used to evaluate terrestrial nitrogen input to estuaries in combination with $\delta^{13} \mathrm{C}$ (e.g. Wada et al. 1987, Thornton and McManus 1994, Middleburg and Nieuwenhuize 1998). However, interpretation of $\delta^{13} \mathrm{C}$ and $\delta^{15} \mathrm{~N}$ signatures is not without caveat when the isotopic values of terrestrial or marine end members are inconsistent over time (Gearing et al. 1984, Ogawa et al. 1994), particularly in estuarine settings where nutrient fluxes from adjacent terrestrial systems are variable and seasonal blooms of phytoplankton are common. Furthermore, phytoplankton isotopic values vary widely throughout aquatic ecosystems (Gearing 1988, Rau et al. 1990, Wada and Hattori 1991, Wainright and Fry 1994, Rolff 2000, Savoye et al. 2003, Sato et al. 2006 and others) due to numerous factors. The main controls over phytoplankton isotope signature can be summarized as: (1) The isotope ratio of the nutrient source (Owens 1987, Fry 1996); (2) the isotope effects associated with nutrient assimilation (Park and Epstein 1960, O’ Leary 
1981, Fogel and Cifuentes 1993, Montoya and McCarthy 1995, Pennock et al. 1996, Waser et al. 1998, 1999, Needoba et al. 2003, 2004) and (3) the isotope effects associated with biosynthesis (Descolas-Gros and Fontugne 1990, Wada and Hattori 1991, Bentaleb et al. 1998, Riebesell 2000). In particular, nutrient availability and isotopic fractionation during nutrient incorporation are of major importance (Rau et al. 1992, Pennock et al. 1996, Korb et al. 1998, Altabet 2001). In terms of nitrogen, because the lighter isotope is preferentially incorporated over the heavier one, nutrient uptake results in enrichment of the heavier isotope in the residual nutrient pool. When the ambient nutrient stock is at high concentration and/or when nutrient demand is low, this enrichment becomes negligible; when the nutrient stock declines (during the course of a plankton bloom), ${ }^{15} \mathrm{~N}$ enrichment increases and the isotope ratio of the phytoplankton incorporating residual nutrient rises. This represents the classic isotopic example of Rayleigh fractionation during surface nutrient utilization which has been invoked in open-ocean systems (Wada 1980, Altabet and Francois 1994, Altabet et al. 1999), coastal ecosystems (Goering et al. 1990, Horrigan et al. 1990), and lake settings (Teranes and Bernasconi 2000).

In terms of $\delta^{13} \mathrm{C}$, the inverse relationship between fractionation and the growth rate/[CO $\left.\mathrm{CO}_{2}\right]_{\mathrm{aq}}$ ratio has been well documented (Laws et al. 1995, 1997, Popp et al. 1998, Burkhardt et al. 1999). The influence of phytoplankton growth rate on isotopic fractionation is more specifically defined by the 2-step model of carbon fixation described by Fry (1996):

$$
\mathrm{CO}_{2(\mathrm{aq}) \mathrm{e}} \leftrightarrow \mathrm{CO}_{2(\mathrm{aq}) \mathrm{i}} \rightarrow \text { fixed } \mathrm{C}
$$

where $\mathrm{CO}_{2(\mathrm{aq}) \mathrm{e}}$ and $\mathrm{CO}_{2(\mathrm{aq}) \mathrm{i}}$ are cell-external and -internal dissolved inorganic carbon pools, respectively. The first step (reversible) consists of the $\mathrm{CO}_{2(\mathrm{aq})}$ 
incorporation/transport (with the possibility of re-release of $\mathrm{CO}_{2(\mathrm{aq})}$ from the internal pool back to the external pool) associated with very low fractionation. The second step (irreversible) is the enzyme catalyzed carboxylation (photosynthetic fixation) associated with potentially large fractionation (Farquhar et al. 1982, Fry 1996). If the photosynthesis rate is low (ie. low growth rate, low nutrient demand), the intracellular $\mathrm{CO}_{2}$ pool is large and uptake rate is limited by the carboxylation reactions. Because of the large fractionation during carboxylation, fractionation for the complete reaction is thus high. In contrast, at high photosynthesis rates (i.e. high growth rate, high nutrient demand), the intracellular carbon pool diminishes as it is rapidly utilized and assimilation rate is limited by the membrane transport of the first step. If all the carbon entering the cell is utilized, little or no fractionation occurs during the whole reaction (Farquhar et al. 1982, Bentaleb et al. 1998).

The final fractionation product of either nitrogen or carbon assimilation is dependent on initial nutrient source isotopic composition, consequently the isotopic signatures of the autocthonous particulate organic carbon and nitrogen may fluctuate, reflecting temporal changes in nutrient sources and metabolic activities (Cifuentes et al. 1988, Ogawa and Ogura 1997, Hellings et al. 1999, Rudnick et al. 1999). Nutrient fluxes from both oceanic and terrestrial Everglades nutrient sources vary extensively on a seasonal basis in the South Florida coastal system. Upwelling events episodically supply the Florida reef tract with influxes of new nutrients (Leichter et al. 2003), while other storm events and weather-driven surface currents transport nutrient fluxes across the western Florida Bay boundary with the Gulf of Mexico and across the Middle Florida Keys channels (Smith 1998, Gibson et al. 2008). Management of freshwater resources in 
the Everglades generates variable nutrient inputs due to water storage in the water conservation areas, punctuated with pulse releases that may or may not mimic seasonal rainfall patterns. Residence time within the storage areas may significantly influence the nutrient species and isotopic composition of the dissolved nutrients later delivered to the downstream coastal zone. Thus a variety of cycling processes and differentiated nutrient sources may be intermingled in the coastal system, complicating the understanding of nutrient cycling and the interpretation of the isotopic composition of autochthonous organic material produced through utilization of variable nutrient resources.

In light of current restoration efforts ongoing in the Everglades drainage system and long term plans to increase freshwater flows to downstream Florida Bay, understanding current variability in the system will become key to understanding the changes sure to develop as restoration progresses. Recent work by Xu and Jaffé (2007) demonstrated significant spatial and temporal variability in Florida Bay POM composition based on a suite of organic biomarker analyses. They concluded that autochthonous marine OM sources were the principle contributors to Florida Bay POM, particularly during the wet season. Spatially, there was a shift in OM sources from marine plankton/seagrass in the SW to mangrove-derived terrestrial material in the NE bay adjacent to the mangrove ecotone; this shift was most evident in the dry season when planktonic productivity declined (Xu and Jaffé 2007). The present study builds upon previous work in order to better understand the sources of seasonal and spatial fluctuation in POM from an isotopic perspective. Size fractionated POM samples were collected on a quarterly basis between September 2002 and January 2005. The purpose of this work was to examine seasonal and spatial isotopic dynamics in different size fractions of POM 
in an effort to separate zooplankton and detrital components, phytoplankton, and cyanobacteria and bacteria into broad groups. Planktonic groups can be expected to respond quickly to changes in water quality, and variations in their geochemical composition may be attributed to environmental parameters. Distinct isotopic fingerprints based on speciation, degree of nutrient utilization, switches between varying $\mathrm{N}$ and $\mathrm{C}$ sources, and $\mathrm{N}$ vs $\mathrm{C}$ limitation may all play a part in influencing the isotopic signatures of different size fractions.

\subsection{METHODS}

\subsubsection{Sampling Protocol}

Sampling of particulate organic matter was conducted on a quarterly basis beginning Sept. 2002 and continuing through Jan. 2005 at 10 sites located within the Florida Keys National Marine Sanctuary and Florida Bay (Figure 3.1; Table 3.1). Samples were collected using a portable pump system (2000 gph bilge pump fitted with a 1.5 inch diameter flexible hose; $12 \mathrm{~V}$ deep cycle marine battery) and two stacked Nitex mesh sieves $(150 \mu \mathrm{m}, 50 \mu \mathrm{m})$ made from 6-inch PVC and marine hose clamps. The upper $1.5 \mathrm{~m}$ of water column was sampled for 30 minutes, allowing more than $3500 \mathrm{~L}$ of water to pass through the sieve system. The $>150 \mu \mathrm{m}$ and $50-150 \mu \mathrm{m}$ samples were rinsed with deionized water from Nitex screens into $30 \mathrm{ml}$ bottles immediately following the sampling interval and were kept on ice for transport to the laboratory. These two size fractions were broadly characterized in terms of speciation using traditional light microscopy. A water sample (1L) was collected after passing through the sieves (the 0.1- 
$50 \mu \mathrm{m}$ size fraction), which was kept on ice until filtration on Whatman Anodisc

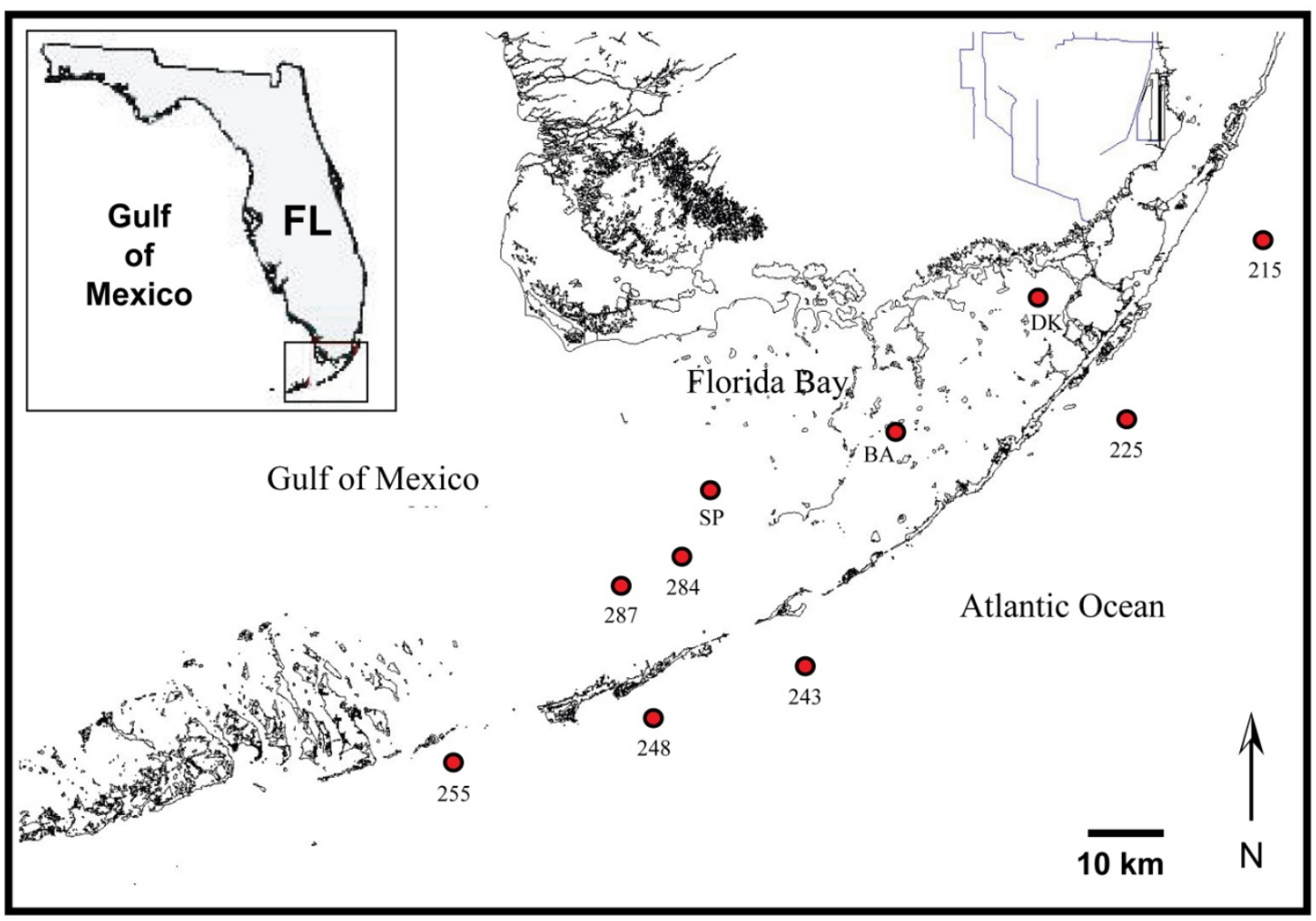

Figure 3.1 Map of Florida Bay and the Florida Keys National Marine Sanctuary, showing POM sampling sites on the Atlantic Ocean side of the Florida Keys: Carysfort Reef (215), Molasses Reef (225), Tennessee Reef (243), Coffins Patch Channel (248), Bahia Honda Channel (255); and in Florida Bay: Tripod Bank (284), Bamboo Bank (287), Sprigger Bank (SP), Bob Allen Bank (BA), and Duck Key (DK).

Table 3.1 POM sampling site locations and mean depths

\begin{tabular}{lcccc}
\hline Site & $\begin{array}{c}\text { Station } \\
\text { number* }\end{array}$ & Latitude & Longitude & $\begin{array}{c}\text { Mean Depth } \\
(\mathrm{m})\end{array}$ \\
\hline Carysfort Reef & 215 & $25^{\circ} 13.314 \mathrm{~N}$ & $80^{\circ} 12.881 \mathrm{~W}$ & 6.1 \\
Molasses Reef & 225 & $25^{\circ} 00.807 \mathrm{~N}$ & $80^{\circ} 22.677 \mathrm{~W}$ & 3.4 \\
Tennessee Reef & 243 & $24^{\circ} 44.588 \mathrm{~N}$ & $80^{\circ} 47.799 \mathrm{~W}$ & 9.1 \\
Coffins Patch Channel & 248 & $24^{\circ} 41.155 \mathrm{~N}$ & $80^{\circ} 58.879 \mathrm{~W}$ & 9.1 \\
Bahia Honda Channel & 255 & $24^{\circ} 37.432 \mathrm{~N}$ & $81^{\circ} 14.725 \mathrm{~W}$ & 9.1 \\
Tripod Bank & 284 & $24^{\circ} 52.605 \mathrm{~N}$ & $80^{\circ} 57.507 \mathrm{~W}$ & 1.5 \\
Bamboo Bank & 287 & $24^{\circ} 50.800 \mathrm{~N}$ & $81^{\circ} 00.499 \mathrm{~W}$ & 2.1 \\
Sprigger Bank & SP & $24^{\circ} 54.771 \mathrm{~N}$ & $80^{\circ} 56.288 \mathrm{~W}$ & 0.75 \\
Bob Allen Bank & BA & $25^{\circ} 01.484 \mathrm{~N}$ & $80^{\circ} 40.859 \mathrm{~W}$ & 1.25 \\
Duck Key & DK & $25^{\circ} 10.617 \mathrm{~N}$ & $80^{\circ} 29.383 \mathrm{~W}$ & 1.7 \\
\hline
\end{tabular}

* Identifier for SERC Water Quality Monitoring Network and FKNMS Seagrass Monitoring Project 
membrane filters $(0.1 \mu \mathrm{m}$ pore size $)$ in the laboratory. Triplicate samples for FACS flow cytometer analyses of the $0.1-50 \mu \mathrm{m}$ size fraction $(2 \mathrm{ml})$ were also collected after passing through the sieves. Samples for FACS analyses were preserved with formalin to a $1 \%$ final concentration. Additional samples were collected from each site for bulk POM isotopic composition during the 2004 sampling quarters. For these samples 10L bulk seawater was collected and filtered at dockage on precombusted $0.45 \mu \mathrm{m} \mathrm{GF} / \mathrm{C}$ glass fiber filters. All size fractions and membrane filters were then dried at $70^{\circ} \mathrm{C}$, powdered, and analyzed for stable isotope ratios following standard IRMS procedures as outlined previously (Evans et al. 2006).

\subsubsection{Flow Cytometer Analyses}

Flow Cytometer analyses of the $0.1-50 \mu \mathrm{m}$ POM fraction were completed for both heterotrophic bacteria and phytoplankton. Analyses of heterotrophic bacteria required a DNA staining procedure (Jochem 2000). For analyses of bulk phytoplankton samples, $1 \mathrm{ml}$ of each replicate sample was analyzed without further processing. All samples were analyzed on a Beckton Dickinson FACSort flow cytometer. SYBR DNA fluorescence was recorded in both the green (FL1) and red (FL3) fluorescence channels (heterotrophic bacteria), whereas the phytoplankton samples were assessed using chlorophyll autofluorescence, detected in the red (FL3) fluorescence channel. For proxy analysis of

relative cell size, Side Angle Light Scatter is measured (SSC channel). All signals are recorded on a 4-decades log scale and all are analyzed using Win MDI 2.7 Software. DNA clusters of bacteria are counted by logical gating from both FL1 vs FL3 and SSC vs 
FL1 dotplots and histograms with gate borders set to minima in population frequency distribution.

\subsubsection{Statistical Analyses}

Data were analyzed using a variety of parametric and non-parametric methods. One-Way Analysis of Variance was completed comparing 2-year datasets among sites and between size fractions within sites, followed by Holm-Sidak tests for post-hoc pairwaise comparisons. Where problems with normality or equal variance occurred among data sets, the Kruskal-Wallis One-Way Analysis of Variance on Ranks was used in place of ANOVA and Dunn's test was used for post hoc pair-wise comparisons. Student's t-tests were used to compare paired, pooled data sets from Florida Bay versus Atlantic Ocean sites where variables were normally distributed, whereas the Mann Whitney Rank Sum Test was used where parametric tests were not appropriate. Pearson Product Moment Correlations were used to assess relationships among variables and water quality parameters, and simple regression analyses were also utilized. All statistical analyses were completed using SigmaPlot 8.0, Systat Software, 2004.

\subsection{RESULTS}

\subsubsection{Time Series}

A high level of spatial and temporal variability is evident in time-series plots of the 2-year size fractionated isotopic dataset from 10 sites in the Florida Keys National Marine Sanctuary (Atlantic Ocean side of the Florida Keys) and within Florida Bay 
(Figures 3.2-7). Mean isotopic compositions, as well as minima and maxima for each size fraction at all stations are summarized in Table 3.2. Figure 3.2 combines data sets from the two northernmost locations sampled, adjacent to two reefs off the Atlantic coast of Key Largo, Carysfort Reef and Molasses Reef. Nutrient concentration data for nitrate $\left(\mathrm{NO}_{3}{ }^{-}\right)$, ammonium $\left(\mathrm{NH}_{4}{ }^{+}\right)$, and soluble reactive phosphorus (SRP) are courtesy of the
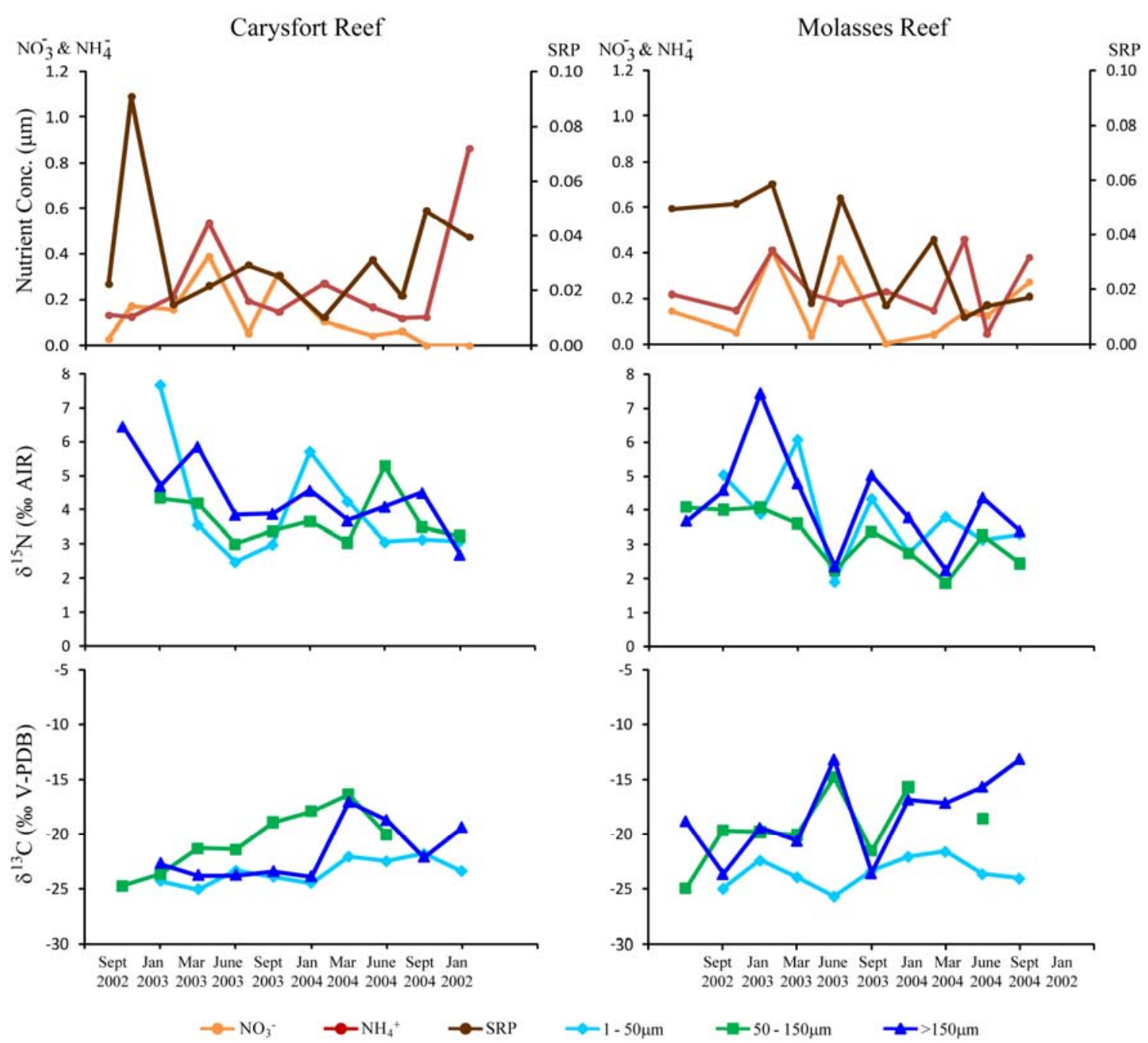

Figure 3.2 Time series of POM isotopic values $\left(\delta^{13} \mathrm{C} \& \delta^{15} \mathrm{~N}\right)$ from 3 size fractions collected quarterly over a two year period from reef settings in the northern Florida Keys. Nutrient concentration data (nitrate, ammonium, and soluble reactive phosphorus) are also shown. 
Table 3.2 Descriptive statistics for each POM size fraction collected from 10 sites in Florida Bay and the Florida Keys National Marine Sanctuary.

\begin{tabular}{|c|c|c|c|c|c|c|c|c|c|c|c|c|c|c|c|c|c|c|c|}
\hline \multirow{3}{*}{$\begin{array}{c}\text { Site } \\
\text { Carysfort Reef }\end{array}$} & \multirow{3}{*}{$\begin{array}{c}\begin{array}{c}\text { Size } \\
\text { Fraction }\end{array} \\
0.1-50 \mu \mathrm{m}\end{array}$} & \multicolumn{6}{|c|}{$\delta^{15} \mathrm{~N}(\% \mathrm{AIR})$} & \multicolumn{6}{|c|}{$\delta^{13} \mathrm{C}(\% \mathrm{PDB})$} & \multicolumn{6}{|c|}{ Molar C:N } \\
\hline & & \multicolumn{3}{|c|}{ Mean \pm St. D. } & \multirow{2}{*}{$\begin{array}{c}\text { Range } \\
5.20\end{array}$} & \multirow{2}{*}{$\begin{array}{l}\text { Max } \\
7.68\end{array}$} & \multirow{2}{*}{$\begin{array}{l}\text { Min } \\
2.48\end{array}$} & \multicolumn{3}{|c|}{ Mean \pm St. D. } & \multirow{2}{*}{$\begin{array}{l}\text { Range } \\
3.25\end{array}$} & \multirow{2}{*}{$\begin{array}{c}\text { Max } \\
-21.81\end{array}$} & \multirow{2}{*}{$\begin{array}{c}\text { Min } \\
-25.06\end{array}$} & \multicolumn{3}{|c|}{ Mean \pm St. D. } & \multirow{2}{*}{$\begin{array}{l}\text { Range } \\
32.21\end{array}$} & \multirow{2}{*}{\begin{tabular}{r|} 
Max \\
37.21
\end{tabular}} & \multirow{2}{*}{$\begin{array}{r}\text { Min } \\
5.13\end{array}$} \\
\hline & & 3.99 & \pm & 1.68 & & & & -23.41 & \pm & 1.12 & & & & 12.77 & \pm & 4.56 & & & \\
\hline & $50-150 \mu \mathrm{m}$ & 3.75 & \pm & 0.74 & 2.27 & 5.29 & 3.02 & -20.53 & \pm & 2.80 & 8.33 & -16.37 & -24.70 & 12.17 & \pm & 5.49 & 13.89 & 18.39 & 4.50 \\
\hline & $>150 \mu \mathrm{m}$ & 4.43 & \pm & 1.08 & 3.75 & 6.45 & 2.70 & -21.65 & \pm & 2.57 & 5.70 & -17.07 & -23.77 & 9.01 & \pm & 9.20 & 27.03 & 27.87 & 0.84 \\
\hline \multirow{3}{*}{ Molasses Reef } & $0.1-50 \mu \mathrm{m}$ & 3.80 & \pm & 1.24 & 4.16 & 6.06 & 1.90 & -23.52 & \pm & 1.35 & 4.12 & -21.58 & -25.70 & 6.63 & \pm & 1.78 & 5.71 & 8.44 & 2.73 \\
\hline & $50-150 \mu \mathrm{m}$ & 3.17 & \pm & 0.80 & 2.19 & 4.07 & 1.89 & -19.33 & \pm & 3.46 & 10.18 & -14.78 & -24.96 & 19.07 & \pm & 8.34 & 22.83 & 30.74 & 7.90 \\
\hline & $>150 \mu \mathrm{m}$ & 4.16 & \pm & 1.49 & 5.21 & 7.44 & 2.23 & -18.21 & \pm & 3.76 & 10.55 & -13.12 & -23.67 & 9.36 & \pm & 7.20 & 19.90 & 21.01 & 1.11 \\
\hline \multirow{3}{*}{$\begin{array}{c}\text { Tennessee } \\
\text { Reef }\end{array}$} & $0.1-50 \mu \mathrm{m}$ & 3.16 & \pm & 1.30 & 4.42 & 6.41 & 1.98 & -23.39 & \pm & 1.14 & 3.87 & -21.64 & -25.51 & 13.81 & \pm & 13.55 & 41.31 & 45.81 & 4.50 \\
\hline & $50-150 \mu \mathrm{m}$ & 3.63 & \pm & 0.91 & 2.98 & 5.56 & 2.58 & -20.50 & \pm & 2.53 & 7.69 & -16.91 & -24.60 & 9.38 & \pm & 9.36 & 27.07 & 28.65 & 1.58 \\
\hline & $>150 \mu \mathrm{m}$ & 4.16 & \pm & 1.34 & 5.21 & 6.55 & 1.35 & -20.90 & \pm & 2.29 & 7.32 & -16.74 & -24.06 & 8.49 & \pm & 4.01 & 14.47 & 17.11 & 2.64 \\
\hline \multirow{3}{*}{$\begin{array}{l}\text { Coffins Patch } \\
\text { Channel }\end{array}$} & $0.1-50 \mu \mathrm{m}$ & 2.32 & \pm & 0.77 & 2.31 & 3.77 & 1.46 & -22.79 & \pm & 1.09 & 3.48 & -20.58 & -24.06 & 7.83 & \pm & 4.04 & 14.57 & 17.46 & 2.89 \\
\hline & $50-150 \mu \mathrm{m}$ & 3.49 & \pm & 0.68 & 2.51 & 4.80 & 2.29 & -18.34 & \pm & 3.17 & 11.24 & -13.10 & -24.34 & 9.62 & \pm & 7.45 & 24.41 & 26.82 & 2.41 \\
\hline & $>150 \mu \mathrm{m}$ & 4.38 & \pm & 0.46 & 1.47 & 5.07 & 3.60 & -18.91 & \pm & 3.10 & 9.33 & -14.37 & -23.70 & 10.31 & \pm & 3.91 & 11.57 & 17.23 & 5.65 \\
\hline \multirow{3}{*}{$\begin{array}{l}\text { Bahia Honda } \\
\text { Channel }\end{array}$} & $0.1-50 \mu \mathrm{m}$ & 2.36 & \pm & 0.77 & 2.13 & 3.57 & 1.44 & -22.05 & \pm & 1.76 & 5.23 & -19.33 & -24.56 & 6.55 & \pm & 4.44 & 13.69 & 17.29 & 3.60 \\
\hline & $50-150 \mu \mathrm{m}$ & 3.82 & \pm & 0.55 & 1.85 & 5.03 & 3.18 & -19.25 & \pm & 2.73 & 9.29 & -15.61 & -24.90 & 8.08 & \pm & 7.97 & 24.63 & 27.57 & 2.95 \\
\hline & $>150 \mu \mathrm{m}$ & 4.45 & \pm & 0.99 & 3.05 & 5.72 & 2.67 & -18.97 & \pm & 5.32 & 16.27 & -10.53 & -26.80 & 8.30 & \pm & 3.94 & 11.58 & 14.73 & 3.15 \\
\hline \multirow[t]{3}{*}{ Tripod Bank } & $0.1-50 \mu \mathrm{m}$ & 3.14 & \pm & 0.92 & 2.81 & 4.47 & 1.66 & -21.14 & \pm & 1.81 & 5.53 & -18.38 & -23.91 & 6.18 & \pm & 2.33 & 5.80 & 9.40 & 3.61 \\
\hline & $50-150 \mu \mathrm{m}$ & 3.95 & \pm & 0.42 & 1.35 & 4.75 & 3.40 & -16.45 & \pm & 2.36 & 5.58 & -14.50 & -20.07 & 7.58 & \pm & 3.32 & 9.31 & 13.37 & 4.06 \\
\hline & $>150 \mu \mathrm{m}$ & 3.90 & \pm & 1.77 & 6.40 & 8.39 & 1.99 & -14.62 & \pm & 3.61 & 9.44 & -10.62 & -20.06 & 13.28 & \pm & 6.16 & 21.05 & 22.59 & 1.54 \\
\hline \multirow[t]{3}{*}{ Bamboo Bank } & $0.1-50 \mu \mathrm{m}$ & 2.13 & \pm & 0.57 & 1.85 & 2.94 & 1.09 & -20.84 & \pm & 2.22 & 6.43 & -17.81 & -24.23 & 7.03 & \pm & 2.66 & 8.69 & 12.01 & 3.33 \\
\hline & $50-150 u \mathrm{~m}$ & 3.72 & \pm & 0.43 & 1.60 & 4.38 & 2.78 & -16.07 & \pm & 1.74 & 6.20 & -13.76 & -19.96 & 7.83 & \pm & 3.15 & 9.79 & 14.95 & 5.16 \\
\hline & $>150 \mu \mathrm{m}$ & 3.49 & \pm & 1.01 & 2.75 & 4.97 & 2.22 & -15.64 & \pm & 4.05 & 13.25 & -7.40 & -20.65 & 9.03 & \pm & 5.82 & 14.77 & 17.02 & 2.25 \\
\hline Sprigger Bank & $0.1-50 \mu \mathrm{m}$ & 3.31 & \pm & 1.00 & 3.03 & 4.60 & 1.57 & -24.04 & \pm & 3.76 & 11.34 & -18.25 & -29.59 & 17.05 & \pm & 25.62 & 70.49 & 73.28 & 2.79 \\
\hline & $50-150 u \mathrm{~m}$ & 4.44 & \pm & 1.05 & 3.68 & 5.81 & 2.13 & -17.61 & \pm & 3.74 & 12.67 & -12.91 & -25.58 & 10.31 & \pm & 5.70 & 19.81 & 23.50 & 3.68 \\
\hline & $>150 \mu \mathrm{m}$ & 3.76 & \pm & 0.97 & 3.12 & 5.09 & 1.97 & -19.47 & \pm & 5.20 & 18.16 & -10.79 & -28.95 & 16.28 & \pm & 15.42 & 51.08 & 53.99 & 2.91 \\
\hline Bob Allen & $0.1-50 \mu \mathrm{m}$ & 2.83 & \pm & 0.38 & 1.05 & 3.28 & 2.24 & -15.43 & \pm & 3.65 & 10.67 & -11.38 & -22.06 & 5.84 & \pm & 3.85 & 9.39 & 12.32 & 2.93 \\
\hline Bank & $50-150 \mu \mathrm{m}$ & 4.28 & \pm & 0.71 & 2.43 & 5.08 & 2.65 & -15.24 & \pm & 1.95 & 5.72 & -13.46 & -19.18 & 16.75 & \pm & 5.06 & 14.37 & 24.51 & 10.15 \\
\hline & $>150 \mu \mathrm{m}$ & 4.37 & \pm & 0.67 & 1.82 & 5.58 & 3.76 & -18.30 & \pm & 4.24 & 12.44 & -12.98 & -25.41 & 17.46 & \pm & 10.22 & 25.94 & 27.94 & 2.00 \\
\hline Duck Key & $0.1-50 \mu \mathrm{m}$ & 4.32 & \pm & 0.41 & 1.29 & 4.85 & 3.56 & -20.06 & \pm & 4.65 & 13.77 & -12.95 & -26.72 & 10.99 & \pm & 4.60 & 13.74 & 19.17 & 5.42 \\
\hline & $50-150 \mu \mathrm{m}$ & 5.49 & \pm & 1.29 & 4.44 & 6.75 & 2.31 & -18.17 & \pm & 1.61 & 4.75 & -15.23 & -19.97 & 19.27 & \pm & 8.27 & 24.37 & 34.30 & 9.93 \\
\hline & $>150 u \mathrm{~m}$ & 6.06 & \pm & 1.51 & 4.61 & 8.52 & 3.91 & -20.58 & \pm & 3.36 & 10.08 & -16.17 & -26.25 & 27.77 & \pm & 41.56 & 122.4 & 130.18 & 7.70 \\
\hline
\end{tabular}


Southeast Environmental Research Center Water Quality Monitoring Network (Florida International University)*1 (Appendix 1).

Nitrogen isotopic compositions appear to be associated with nutrient availability at several intervals during the sampling period in all three POM size fractions at the reefs. Specifically, in the case of Carysfort Reef, enriched isotopic values in all three POM fractions seem to correspond to concentration increases in DIN (dissolved $\mathrm{NO}_{3}{ }^{-}$and $\mathrm{NH}_{4}{ }^{+}$), however this relationship is not consistently obvious over time. In the $0.1-50 \mu \mathrm{m}$ and $50-150 \mu \mathrm{m}$ fractions (the bacteria/cyanobacteria- and larger phytoplankton-associated size ranges) at both northern reef sites, January nitrogen isotopic values tended to be more enriched, while spring samplings showed more depleted signals. Although chlorophyll- $a$ concentrations in the reef setting are habitually low, the winter samplings in 2003, 2004, and 2005 were coincident with intra-annual chlorophyll- $a$ concentration maximums. Carbon isotopic values also exhibit high variability; however, a repetitive annual signal was only apparent in the $0.1-50 \mu \mathrm{m}$ fraction at the Molasses Reef site, with repeated depletions in the winter sampling periods.

The Middle Florida Keys channel and patch reef time series are shown in Figures 3.3 and 3.4 (Tennessee Reef and Coffins Patch Channel, Figure 3.3; Bahia Honda Channel 3.4). These sites exhibit similar trends to the northern reef sites, demonstrating episodic relationships between pulsed nutrient inputs and changes in POM isotopic compositions. The $50-150 \mu \mathrm{m}$ size fraction here too shows some evidence for annual cycling, with 2\%o nitrogen isotopic enrichments repeated in all March and June sampling

\footnotetext{
${ }^{1}$ Data were provided by the SERC-FIU Water Quality Monitoring Network which is supported by SFWMD/SERC Cooperative Agreement \#4600000352 as well as EPA Agreement \#X7-96410603-3
} 


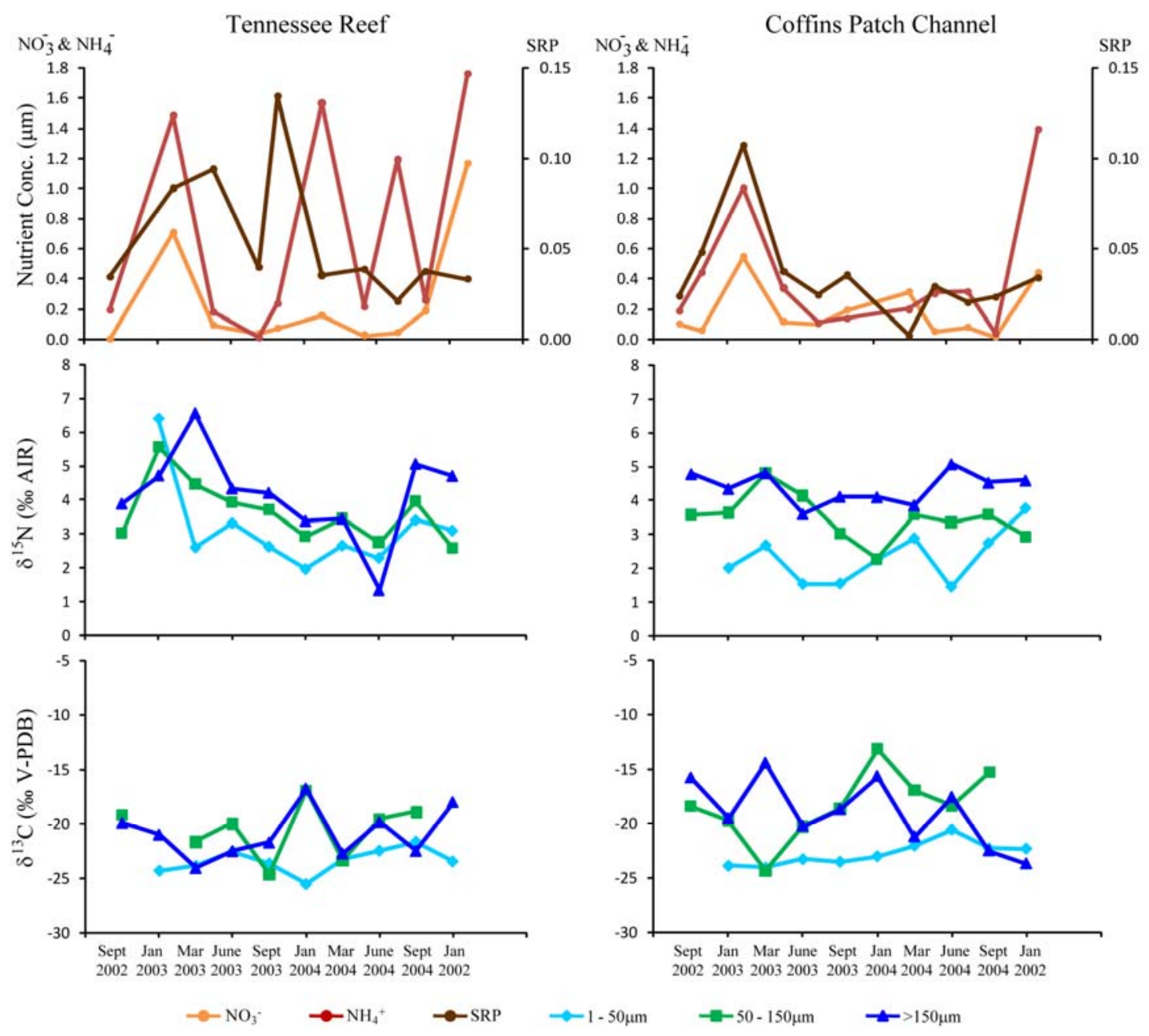

Figure 3.3 Time series of POM isotopic values $\left(\delta^{13} \mathrm{C} \& \delta^{15} \mathrm{~N}\right)$ from 3 size fractions collected quarterly over a two year period from reef and channel settings in the Middle Florida Keys. Nutrient concentration data (nitrate, ammonium, and soluble reactive phosphorus) are also shown.

events, while the January signal was repeatedly depleted. The same trend was apparent in the $0.1-50 \mu \mathrm{m}$ size fraction at the Middle Keys sites. $\delta^{13} \mathrm{C}$ in particular showed depletions in successive January sampling events. Nitrogen isotopic changes in this size fraction were less clear, exhibiting January depletions at Tennessee Reef and Bahia Honda Channel, but the opposite trend at Coffins Patch Channel, which had enriched $\delta^{15} \mathrm{~N}$ values during winter sampling intervals and depleted signatures in the summer. Western Florida Bay sites, Tripod Bank, Bamboo Bank, and Sprigger Bank, are 


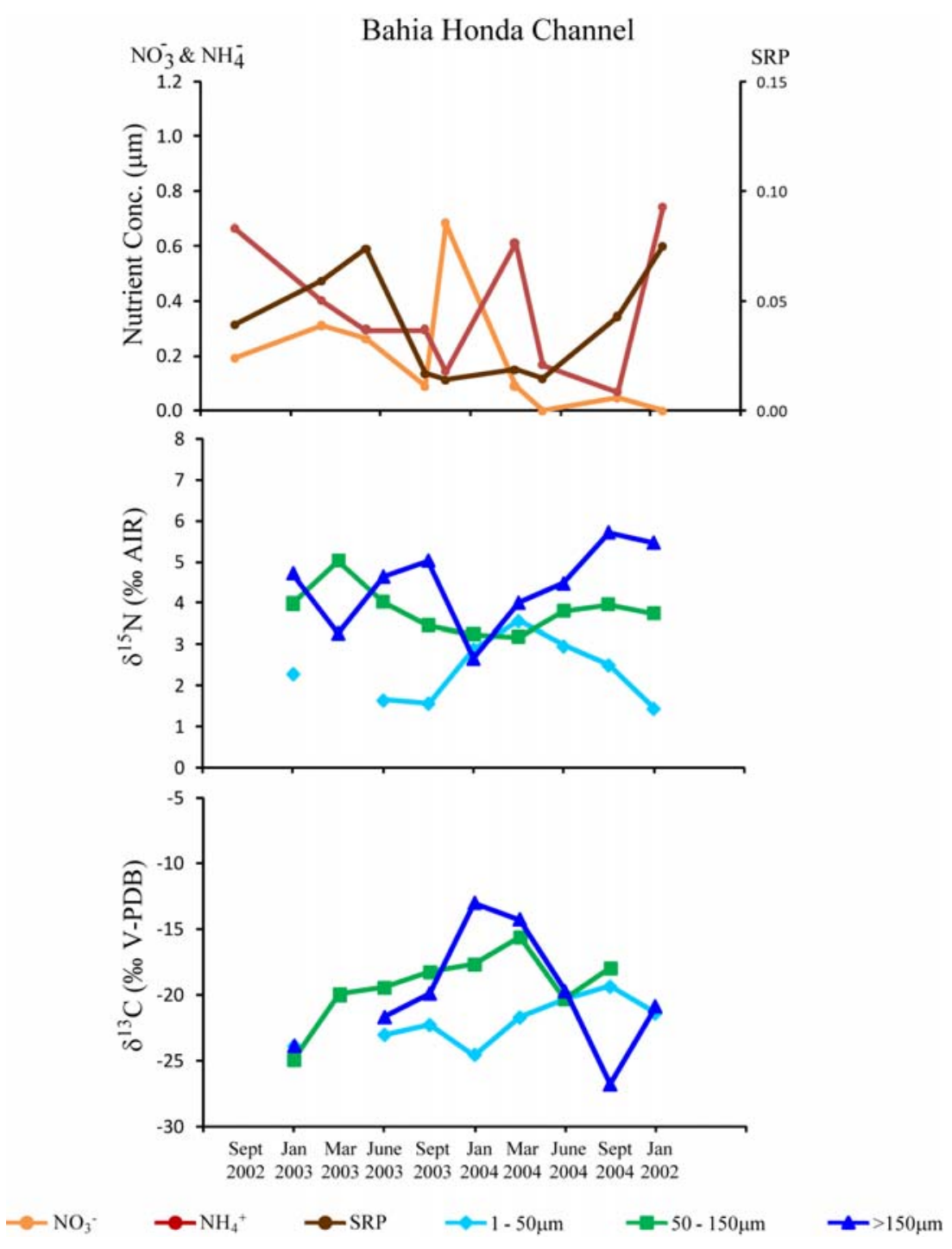

Figure 3.4 Time series of POM isotopic values $\left(\delta^{13} \mathrm{C} \& \delta^{15} \mathrm{~N}\right)$ from 3 size fractions collected quarterly over a two year period from a channel setting in the Middle Florida Keys. Nutrient concentration data (nitrate, ammonium, and soluble reactive phosphorus) are also shown.

shown in Figures 3.5 and 3.6. These sites were characterized by markedly low nutrient availability throughout the sampling period; however, as in the sites previously described, there was a relationship between the nutrient parameters and the POM isotopic values, with nitrogen isotopic enrichment and depletion cycles closely following nutrient availabilities. The most pronounced nitrogen isotope trends were evident in the 50$150 \mu \mathrm{m}$ and $0.1-50 \mu \mathrm{m}$ size classes at Tripod and Bamboo Banks, with more depleted $\delta^{15} \mathrm{~N}$ 


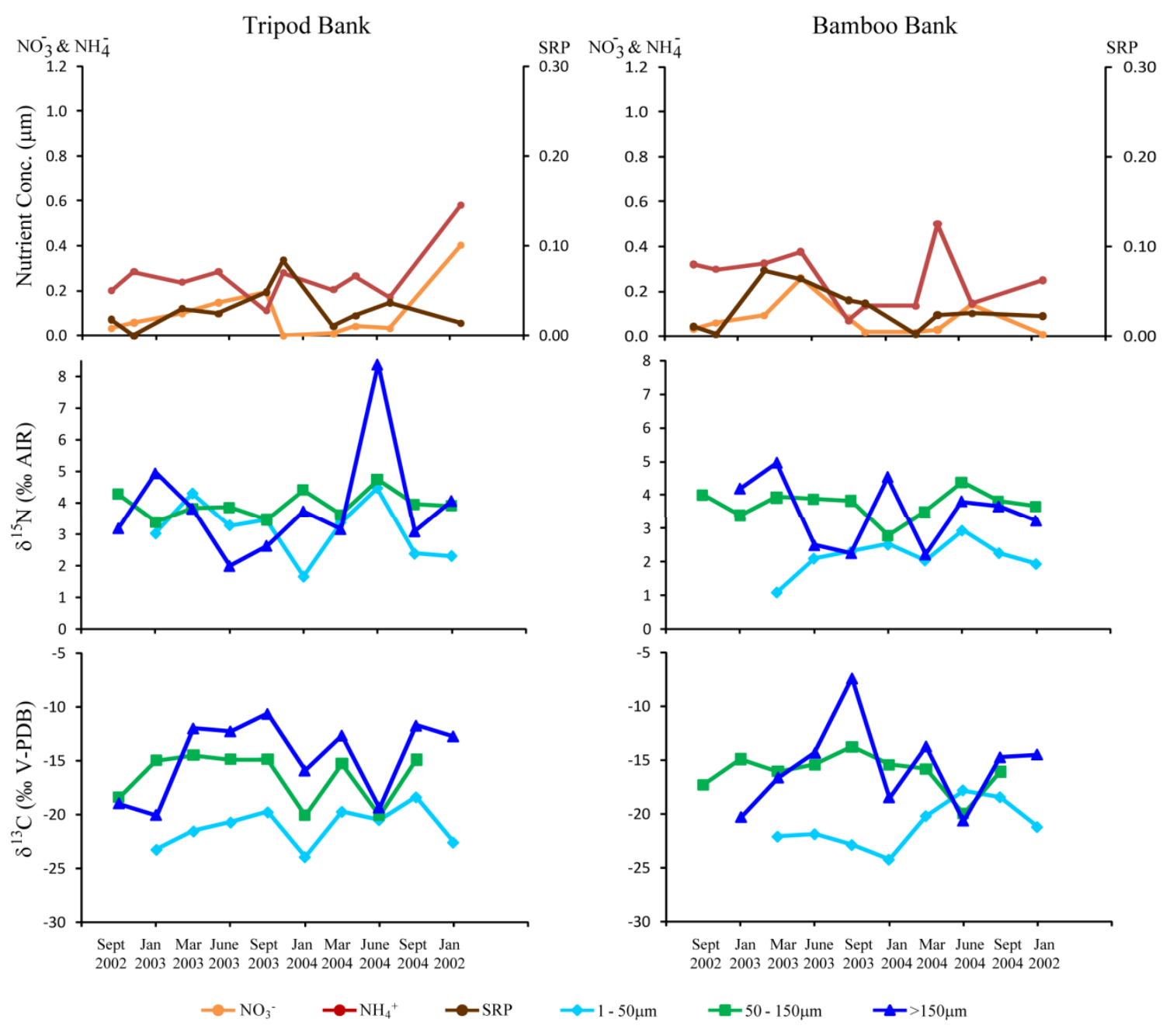

Figure 3.5 Time series of POM isotopic values $\left(\delta^{13} \mathrm{C} \& \delta^{15} \mathrm{~N}\right)$ from 3 size fractions collected quarterly over a two year period from shallow mudbank settings in Western Florida Bay. Nutrient concentration data (nitrate, ammonium, and soluble reactive phosphorus) are also shown.

values shown in the three successive January samplings, and more enriched signals

apparent in the March and June sampling events. Carbon isotopic values in the $0.1-50 \mu \mathrm{m}$

size class exhibited similar patterns of January at these two banks; however, the trend

was less clear in the $50-150 \mu \mathrm{m}$ size class. Sprigger Bank POM isotopic trends were

more complicated than those seen at nearby sites. Annual patterns were more

ambiguous, though still present, and slightly out of phase with patterns seen in the Middle

Keys and other Western Florida Bay sites. The most depleted nitrogen isotopic values 
were found repeatedly in September sampling intervals, with more enriched signatures observed in March and June quarters.
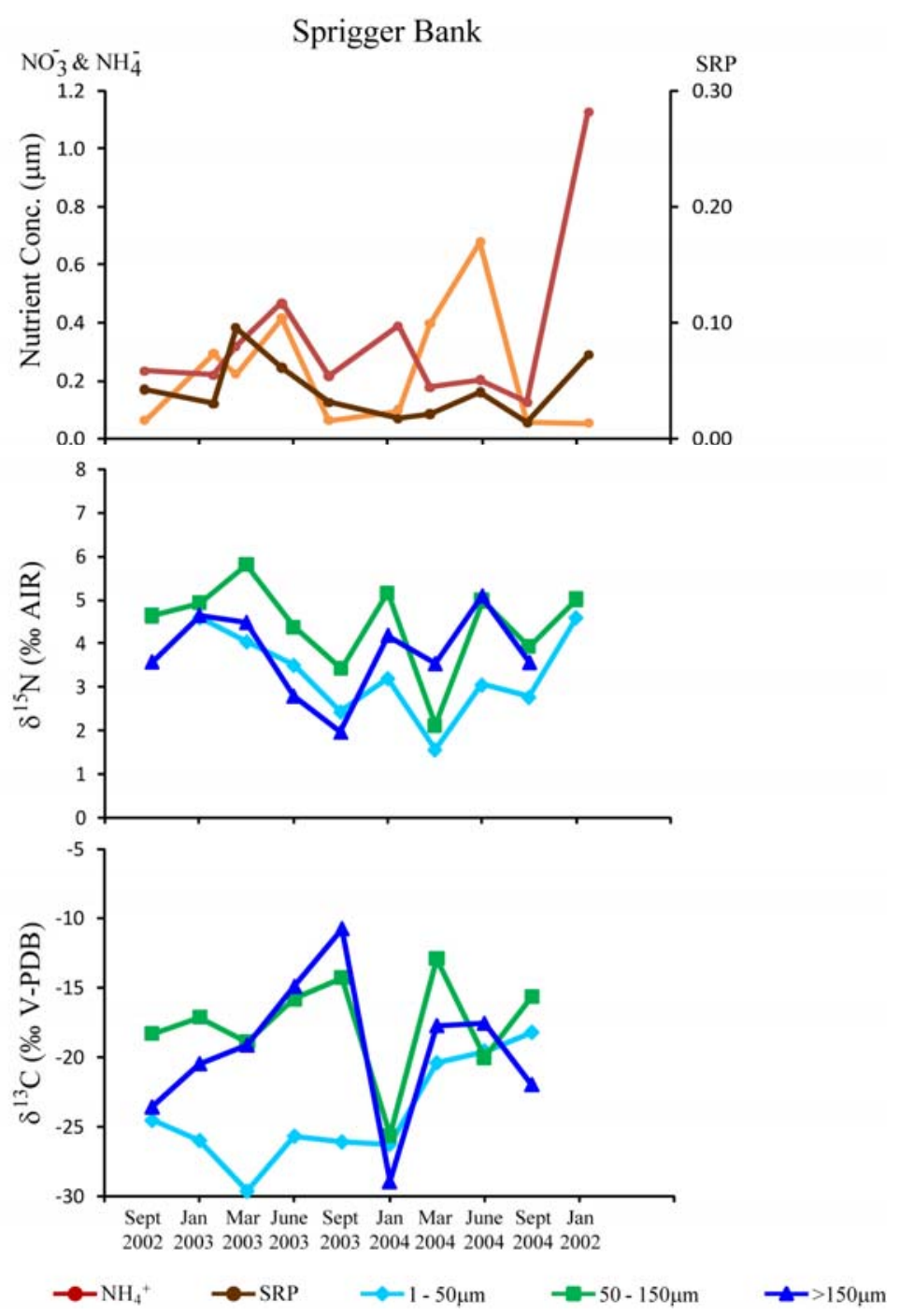

Figure 3.6 Time series of POM isotopic values $\left(\delta^{13} \mathrm{C} \& \delta^{15} \mathrm{~N}\right)$ from 3 size fractions collected quarterly over a two year period from a shallow mudbank setting in Western Florida Bay. Nutrient concentration data (nitrate, ammonium, and soluble reactive phosphorus) are also shown.

The central (Bob Allen Bank) and northeastern (Duck Key) Florida Bay sites time-series are shown in Figure 3.7, exhibiting the most pronounced seasonal nitrogen isotopic signal in spring isotopic enrichments and fall depletions in the phytoplankton size fractions. At Duck Key, a 4\%o depletion in $\delta^{15} \mathrm{~N}$ of the $50-150 \mu \mathrm{m}$ fraction in the Sept. 2004 sampling 
was coincident with a large influx of inorganic phosphorus (SRP), however trends in other size fractions were more ambiguous. A similar, but smaller magnitude, depletion was found at Bob Allen Key with no concurrent changes in nutrient availability.

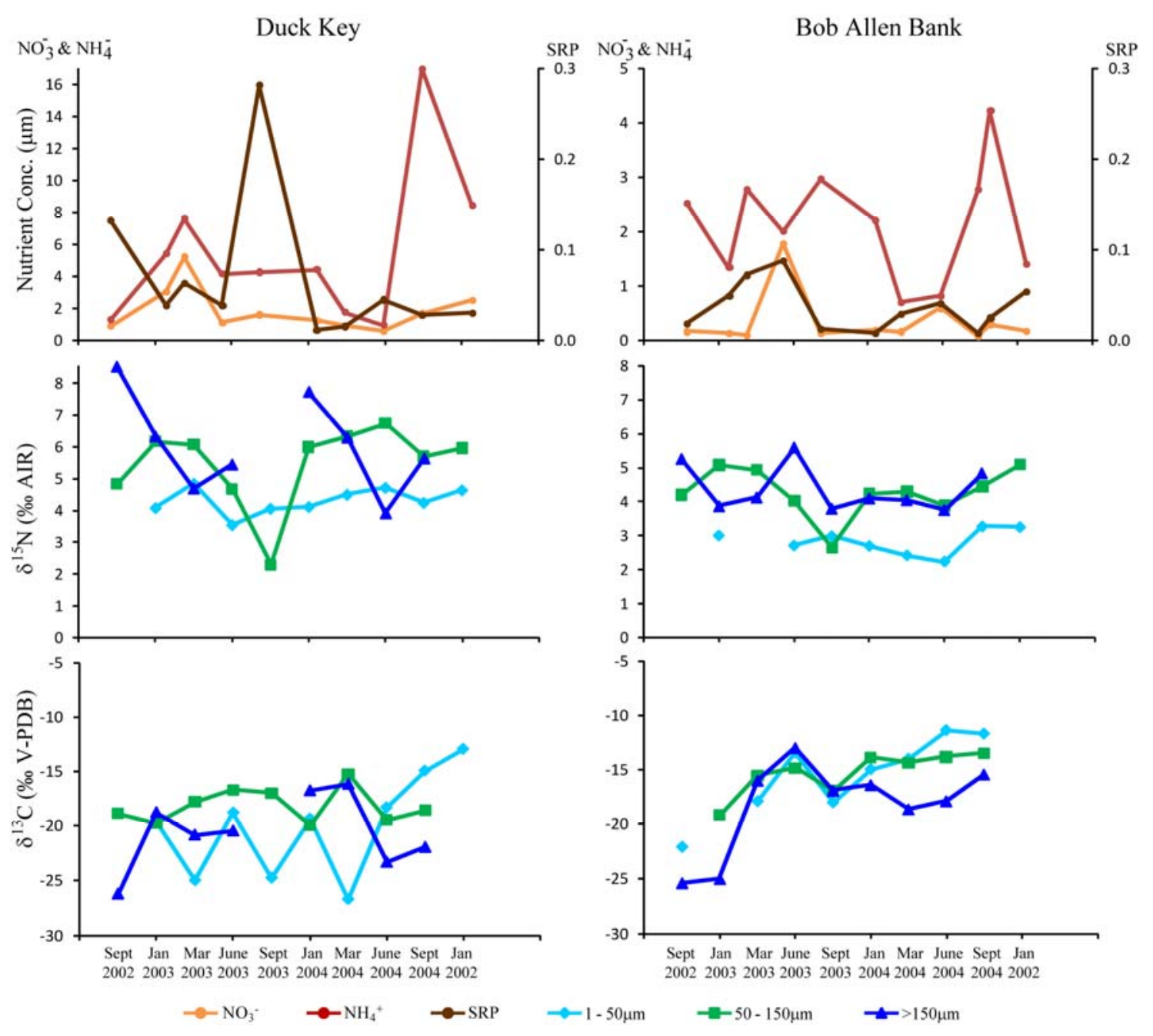

Figure 3.7 Time series of POM isotopic values $\left(\delta^{13} \mathrm{C} \& \delta^{15} \mathrm{~N}\right)$ from 3 size fractions collected quarterly over a two year period from shallow mudbank settings proximal to both islands and Everglades outflows in Northeastern and Central Florida Bay. Nutrient concentration data (nitrate, ammonium, and soluble reactive phosphorus) are also shown.

Figure 3.8 shows time series $\delta^{15} \mathrm{~N}$ data by month, combining the two years of samples collected in the $0.1-50$ and $50-150 \mu \mathrm{m}$ fractions to show average annual trends.

Sites were grouped according to annual isotopic patterns. The Atlantic reef sites 
(Carysfort Reef and Molasses Reef) exhibit nitrogen isotopic enrichment in January, with depletion in June. The Middle Keys Channels sites (Tennessee Reef, Coffins Patch Channel, Bahia Honda Channel, Tripod Bank, and Bamboo Bank) had depleted $\delta^{15} \mathrm{~N}$ values in January with isotopic enrichment evident in the spring and summer quarters. Florida Bay sites (Sprigger Bank, Bob Allen Bank, and Duck Key) showed a pattern of depletion in September with enrichment throughout the rest of the year.
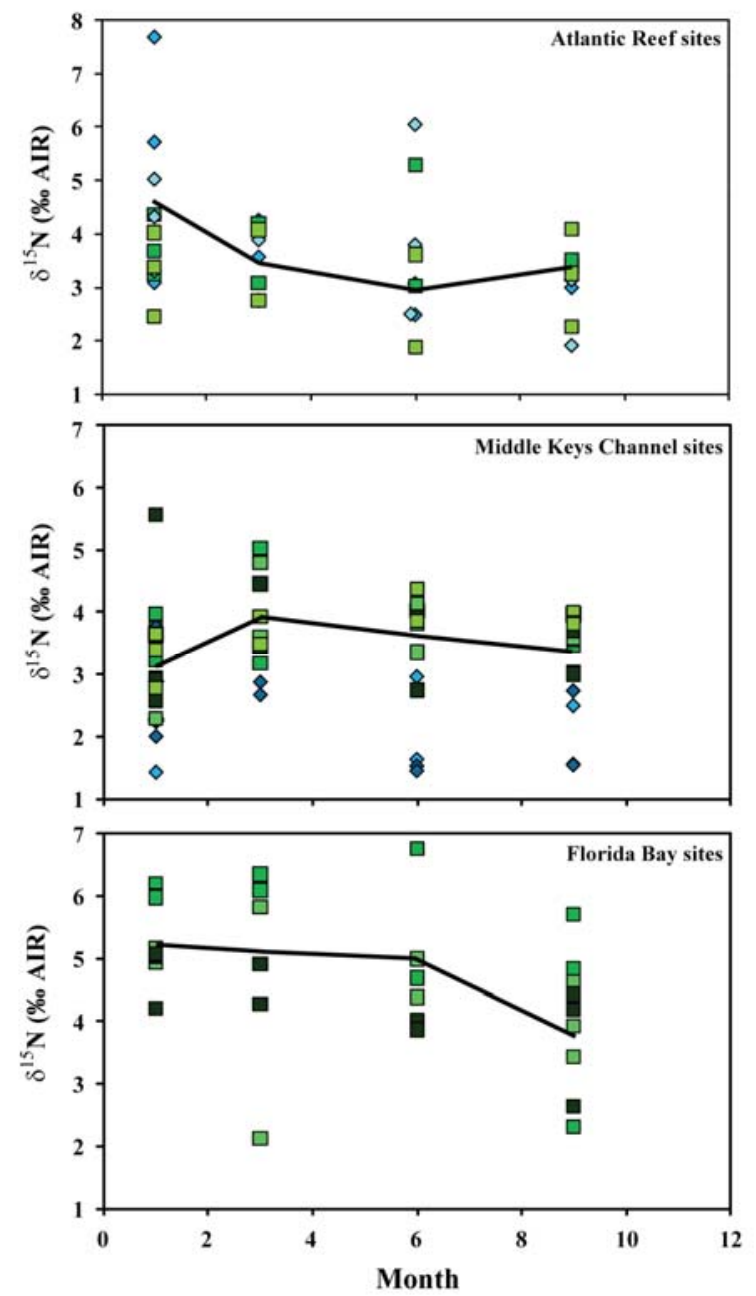

Figure 3.8 Mean annual patterns in $\delta^{15} \mathrm{~N}$ values; 2 years combined. Diamonds denote 0.1-50 $\mu \mathrm{m}$ size fraction, squares denote $\mathbf{5 0 - 1 5 0} \mu \mathrm{m}$ size fraction. Atlantic Reef sites include Carysfort and Molasses Reef; Middle Keys channels include Tennessee Reef, Coffins Patch Channel, Bahia Honda Channel, Tripod Bank and Bamboo Bank; Florida Bay includes Sprigger Bank, Bob Allen Bank, and Duck Key. 
While there appeared in many instances to be relationships between site-specific nutrient parameters and isotopic values, only one site, Duck Key in Northeastern Florida Bay, exhibited statistically significant correlations between nutrient concentration and isotopic composition. At Duck Key, salinity was found to be positively correlated with $\delta^{15} \mathrm{~N}$ in the $50-150 \mu \mathrm{m}$ size fraction $(\mathrm{R}=0.713 ; \mathrm{p}=0.02)$ and negatively correlated with the $>150 \mu \mathrm{m}$ size class $(\mathrm{R}=-0.788 ; \mathrm{p}=0.02) . \delta^{15} \mathrm{~N}$ of the $50-150 \mu \mathrm{m}$ fraction from Duck Key was also negatively correlated with phosphorus concentrations (SRP) $(\mathrm{R}=-0.891$; $\mathrm{p}<0.001)$. There were no statistically significant correlations between two-year datasets of water quality parameters and isotopic compositions of POM and the remaining sites.

\subsubsection{Size Class Variability}

Differences between POM size fractions in nitrogen and carbon isotopic values are illustrated in Figures 3.9 -3.11. With a few exceptions, there was a trend of isotopic enrichment with increasing size fraction. Results of one-way ANOVA tests comparing size classes within each sampling location are summarized in Table 3.3.

Table 3.3 Differences between size fractions: ANOVA P-Values

\begin{tabular}{lllllll}
\hline Site & $\delta^{15} \mathrm{~N}(\% \mathrm{AIR})$ & $\delta^{13} \mathrm{C}(\% \mathrm{PDB})$ & \multicolumn{2}{l}{ Molar C:N } \\
\hline Carysfort Reef & 0.475 & & 0.099 & & 0.533 & \\
Molasses Reef & 0.204 & & $\mathbf{0 . 0 0 3}$ & $a b, a c$ & $\mathbf{0 . 0 1}$ & $a b, b c$ \\
Tennessee Reef & 0.142 & & $\mathbf{0 . 0 1 4}$ & $a b, a c$ & 0.533 & \\
Coffins Patch Channel & $\mathbf{0 . 0 0 1}$ & $a b, a c, b c$ & $\mathbf{0 . 0 0 3}$ & $a b, a c$ & 0.607 & \\
Bahia Honda Channel & $\mathbf{0 . 0 0 1}$ & $a b, a c$ & 0.111 & & 0.287 & \\
Tripod Bank & 0.089 & & $\mathbf{0 . 0 0 1}$ & $a b, a c$ & $\mathbf{0 . 0 0 4}$ & $a c, b c$ \\
Bamboo Bank & $\mathbf{0 . 0 0 3}$ & $a b, a c$ & $\mathbf{0 . 0 0 3}$ & $a b, a c$ & 0.95 & \\
Sprigger Bank & 0.066 & & $\mathbf{0 . 0 1 2}$ & $a b, a c$ & 0.485 & \\
Bob Allen Bank & $\mathbf{0 . 0 0 1}$ & $a b, a c$ & 0.175 & & $\mathbf{0 . 0 2 4}$ & $a b, a c$ \\
Duck Key & $\mathbf{0 . 0 1 4}$ & $a b, a c$ & 0.325 & & 0.068 & \\
\hline
\end{tabular}

*Significant P-values are shown in bold, specific pairwise differences are denoted: $a$ $0.1-50 \mu \mathrm{m} ; b$ 50-150 $\mathrm{mm} ; c>150 \mu \mathrm{m}$. 
Significant differences were identified at several stations, however, differences in $\delta^{15} \mathrm{~N}$ and $\delta^{13} \mathrm{C}$ were not necessarily coincident, indicating decoupling between carbon and nitrogen cycling reflected in POM isotopic values. $\delta^{15} \mathrm{~N}$ values increased significantly with particle size class at half of the study sampling locations; Coffins Patch Channel (site 248), Bahia Honda Channel (site 255), Bamboo Bank (site 287), at Bob Allen Bank (BA) and at Duck Key (DK). At Coffins Patch Channel, there were significant differences between all fractions, with a $1 \%$ enrichment with each size class increase, however at the remaining locations only the $0.1-50 \mu \mathrm{m}$ fraction was significantly depleted (by 1.1 to $1.6 \%$ depending on site, see Table 3.1 ) in nitrogen isotopic composition relative to both the $50-150 \mu \mathrm{m}$ and $>150 \mu \mathrm{m}$ fractions, while the larger two fractions did not differ from one another. In terms of $\delta^{13} \mathrm{C}$, relationships between size fraction isotopic compositions show much higher variability with less consistent trends, yet significant increases in isotopic enrichment with particle size were evident at Molasses Reef (225), Tennessee Reef (243), Coffins Patch Channel (248), Tripod Bank (284), Bamboo Bank (287), and at Sprigger Bank (SP). Carbon isotopes of all size fractions significantly differed at both Molasses Reef and Tennessee Reef, showing 5\%o and 2\%o enrichments across the size classes, respectively. At the remaining sites, comparable with $\delta^{15} \mathrm{~N}$ differences, the $0.1-50 \mu \mathrm{m}$ size class was significantly depleted relative to the larger fractions, yet the $50-150 \mu \mathrm{m}$ and $>150 \mu \mathrm{m}$ fraction did not differ significantly from one another. The relationship between size fraction samples and bulk POM samples is shown in Figure 3.11. The nitrogen isotopic composition of the three size fractions collected in a given sampling event are shown along with a single bulk sample. 

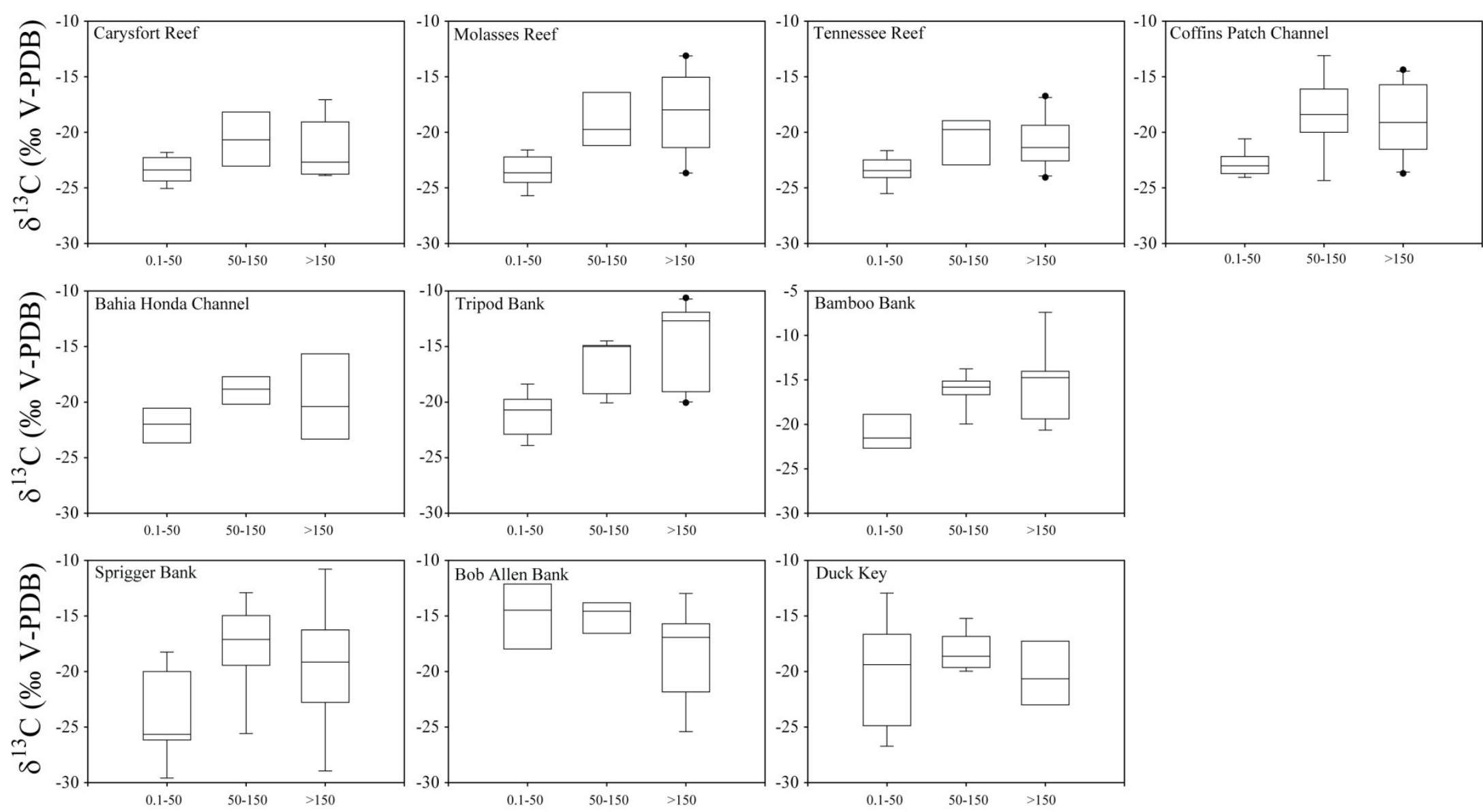

POM Size fraction $(\mu \mathrm{m})$

Figure 3.9 Variation in $\delta^{13} \mathrm{C}$ between POM size fractions combining ten sampling intervals. Box plots show median, upper and lower quartiles, and data extremes over 10 sampling intervals in the three size fractions. 

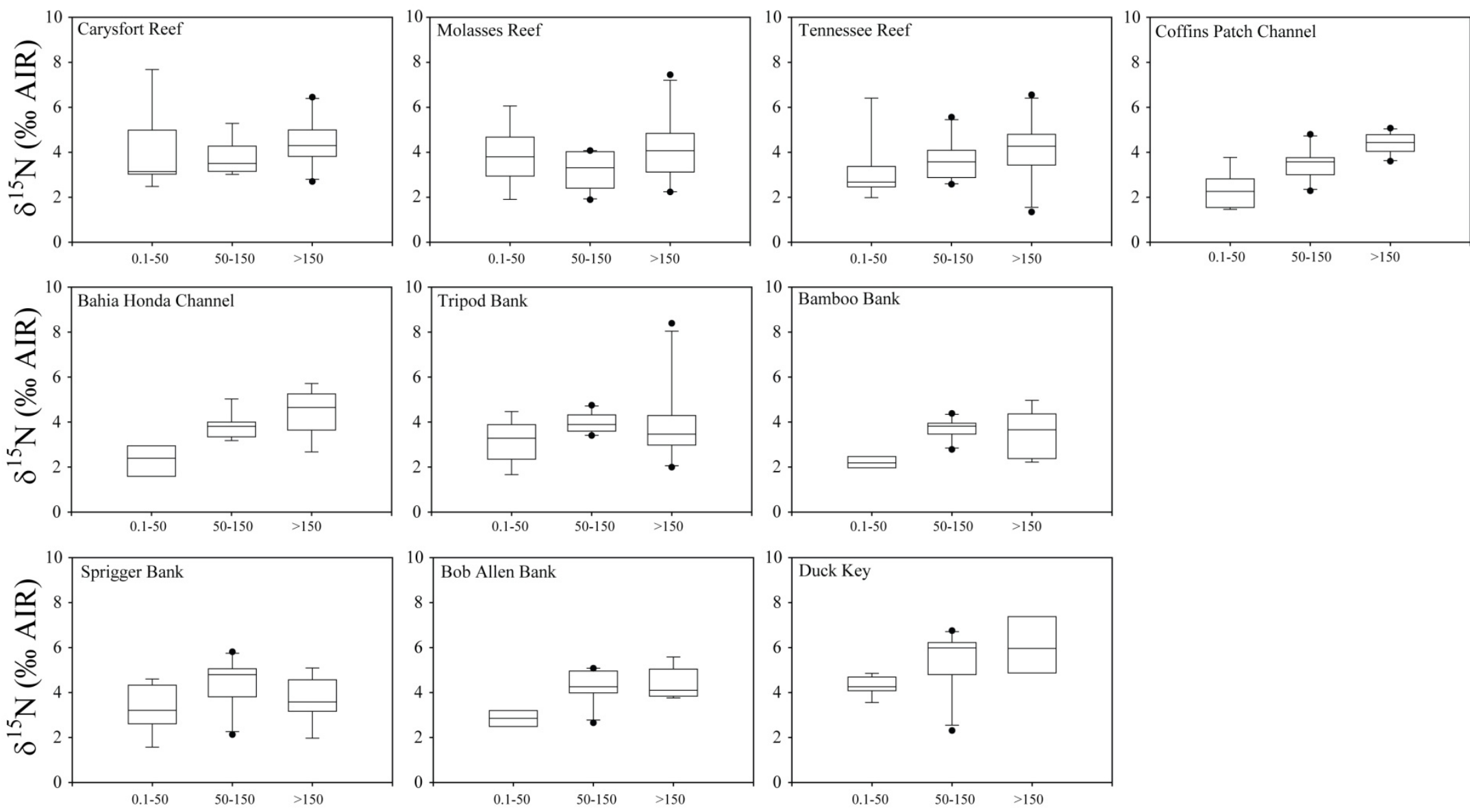

POM Size fraction $(\mu \mathrm{m})$

Figure 3.10 Variation in $\delta^{15} \mathrm{~N}$ between POM size fractions combining ten sampling intervals. Box plots show median, upper and lower quartiles, and data extremes over 10 sampling intervals in the three size fractions. 

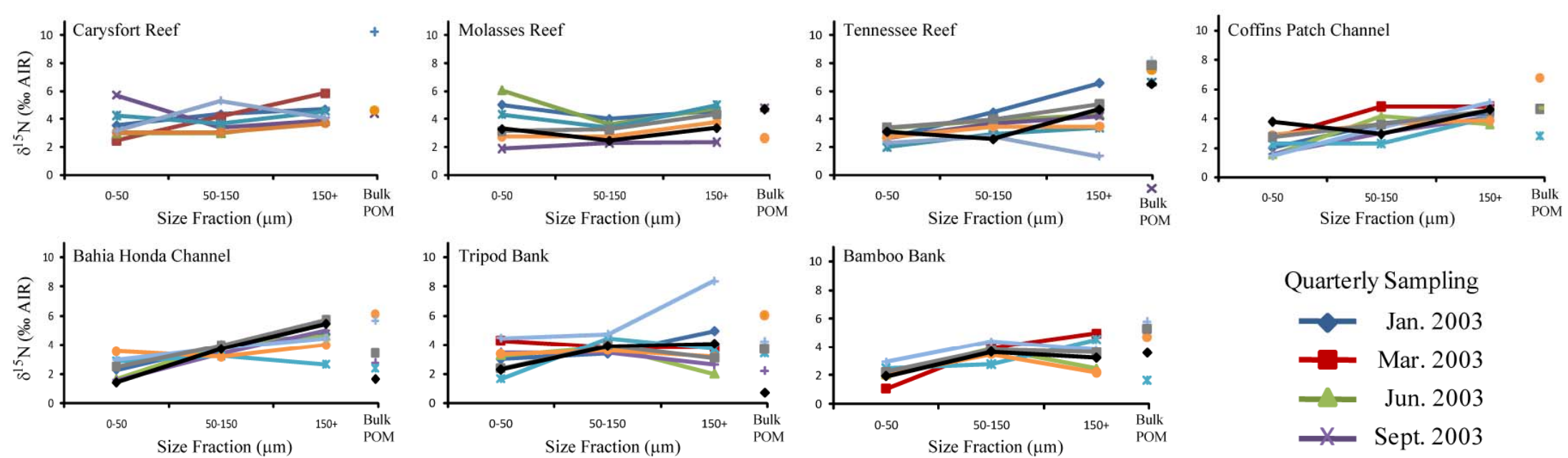

Quarterly Sampling

—Jan. 2003

- Mar. 2003

- Jun. 2003

- Sept. 2003

* Jan. 2004

- Mar. 2004

- Jun. 2004

- Sept. 2004
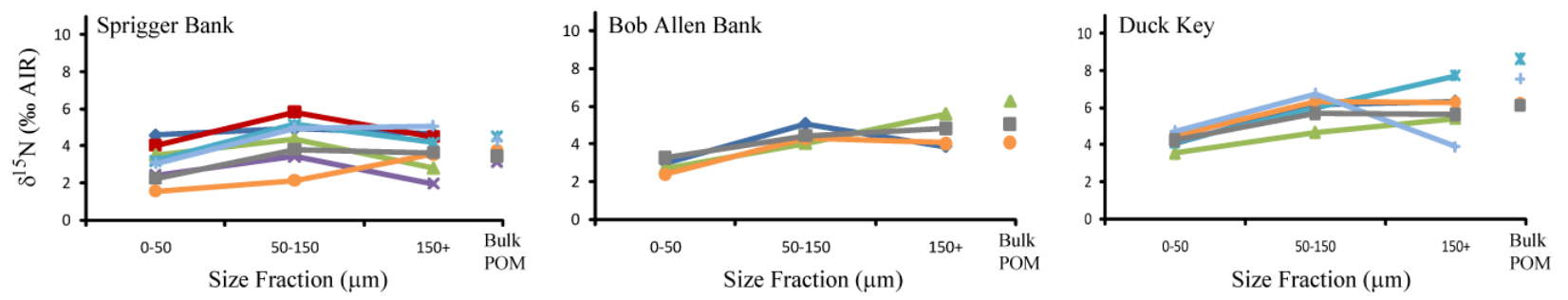

$\sim$ Jan. 2005

Figure 3.11 Variation in $\delta^{15} \mathrm{~N}$ between POM size fractions during individual sampling intervals. Bulk samples corresponding to sampling periods in 2004 are shown with symbols on the right margin of each plot. 
Differences between bulk POM $\delta^{15} \mathrm{~N}$ compositions and the size fractionated dataset vary by station and by sampling interval with no consistent pattern evident. In some samples, the bulk isotopic values were similar to one or more of the corresponding size fraction samples; in other samples, bulk isotopic compositions appeared to reflect an average of the three fractions; yet in still other samples bulk values were completely inconsistent with the size fraction data. Inconsistency between amalgamated versus size separated samples demonstrates the high levels of heterogeneity in mixed bulk samples. Any particle of anomalous isotopic composition will control the overall isotopic composition measured.

Isotopic values among different sampling locations separated into individual size classes (e.g., cross-site comparisons of all $\delta^{15} \mathrm{~N}$ or $\delta^{13} \mathrm{C}$ from the $0.1-50 \mu \mathrm{m}$ fraction) showed significant differences among sites in both $\delta^{15} \mathrm{~N}$ and $\delta^{13} \mathrm{C}$. However, pair-wise comparisons isolating differences demonstrated that Duck Key, in Northeastern Florida Bay, differed significantly from all other sites in terms of $\delta^{15} \mathrm{~N}$ at both the $50-150 \mu \mathrm{m}$ and $>150 \mu \mathrm{m}$ size levels; however, all other specific differences in isotopic composition by specific size fractions can be categorized as differences between site groups "Florida Bay" versus "Atlantic Ocean". The trends separating Bay and Ocean sites in all size classes are shown in bivariate isotope plots (Figure 3.12). In the $0.1-50 \mu \mathrm{m}$ fraction (Figure 3.12A) there was much higher variability in $\delta^{13} \mathrm{C}$ values from the Florida Bay sites, whereas the Ocean sites showed higher variability in $\delta^{15} \mathrm{~N}$. Carbon and nitrogen isotopic values were not however significantly correlated in either Bay or Ocean sites in

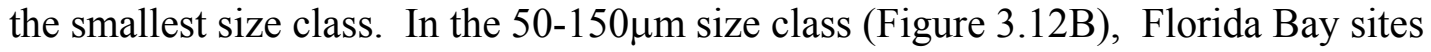



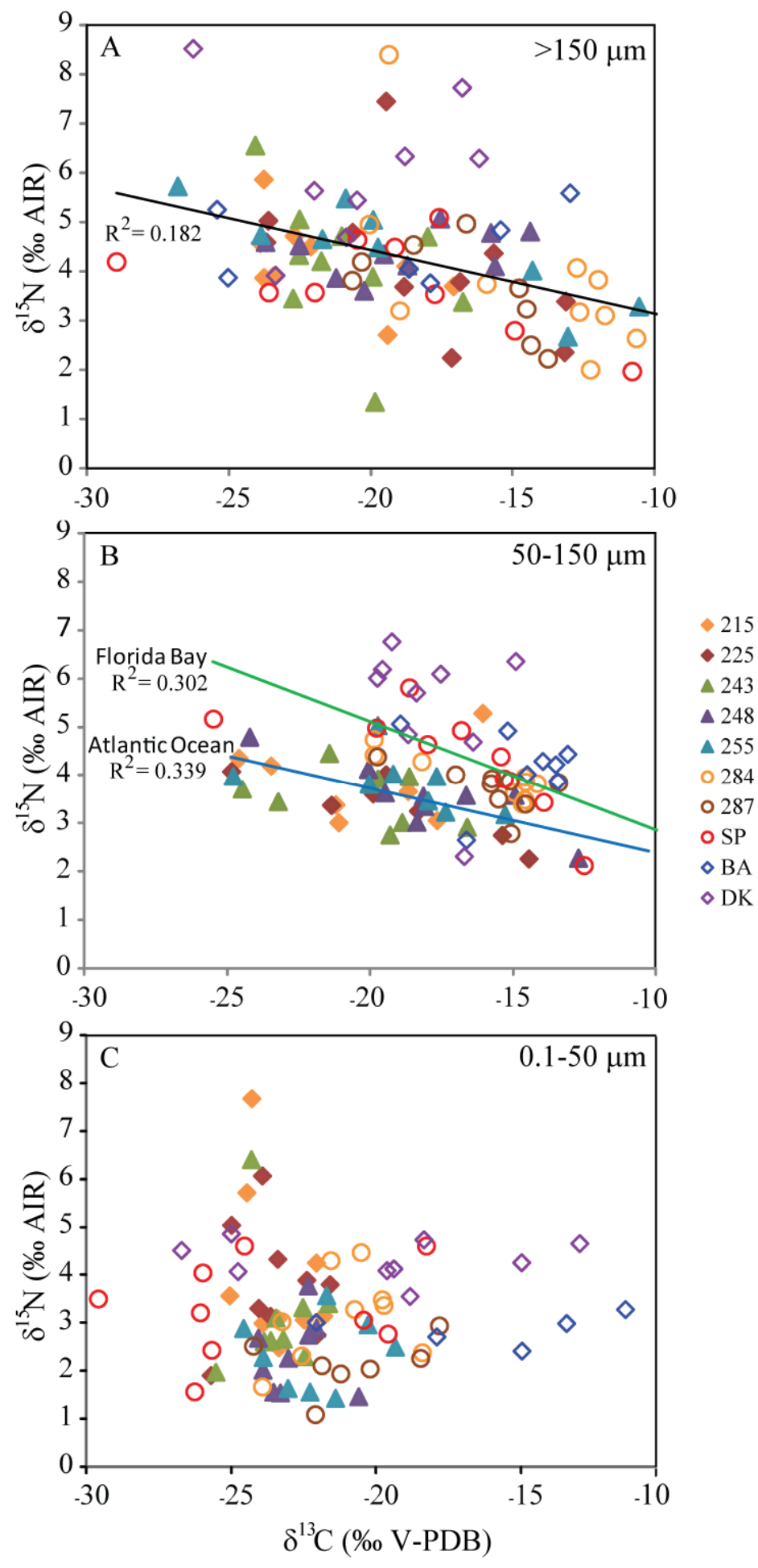

Figure 3.12 Bivariate isotope plots of $\delta^{13} \mathrm{C}$ and $\delta^{15} \mathrm{~N}$ for the three size fractions. A: $>150 \mu \mathrm{m}$ B: 50$150 \mu \mathrm{m}$ C: $0.1-50 \mu \mathrm{m}$. Open symbols denote Florida Bay sampling sites, closed symbols represent Atlantic Ocean sites. 
clearly have more enriched $\delta^{15} \mathrm{~N}$ than Ocean-side sites but the differences in both $\delta^{15} \mathrm{~N}$ and $\delta^{13} \mathrm{C}$ values between Bay and Ocean groups were statistically significant $(\mathrm{p}<0.001)$. Further, carbon and nitrogen values showed significant negative correlations in both groups with Bay and Ocean correlation coefficients (Pearson R-values) of -0.549 and 0.582 respectively, both significant at the $\mathrm{p}<0.001$ level. Figure $3.12 \mathrm{C}$ illustrates that there was no significant difference in $\delta^{15} \mathrm{~N}$ between Bay and Ocean site groups in the $>150 \mu \mathrm{m}$ size fraction; however, $\delta^{13} \mathrm{C}$ values were significantly different $(\mathrm{p}<0.05)$. Carbon and nitrogen isotopic values were also significantly correlated in this size fraction, demonstrating correlation coefficients of -0.457 and -0.443 in Bay and Oceanside groupings, respectively.

\subsubsection{Source indicators of POM}

Bivariate plots comparing isotopic and molar $\mathrm{C}: \mathrm{N}$ ratio values are shown in Figure 3.13. There was no linear relationship relating either $\delta^{15} \mathrm{~N}$ or $\delta^{13} \mathrm{C}$ to $\mathrm{C}: \mathrm{N}$ ratio however differences between size fractions and between Florida Bay and Atlantic Ocean site pools are evident. Values for the $\mathrm{C}: \mathrm{N}$ ratios of the different size classes ranged from $0.84-53.8$, however the majority of values were less than 30 . The $0.1-50 \mu \mathrm{m}$ size class were clustered with $\mathrm{C}: \mathrm{N}$ values $<10$ with both Florida Bay and Atlantic Ocean site pools.

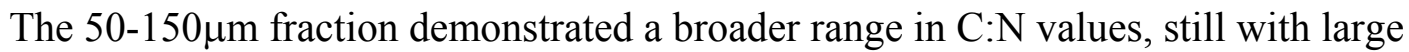
proportion in the 5-10 range, but with a significant number of samples falling between 10 and 30. The distinction between Florida Bay and Atlantic Ocean site pools is apparent, with the Florida Bay values showing a wider range in both isotopic values and $\mathrm{C}: \mathrm{N}$ ratios. The $>150 \mu \mathrm{m}$ fraction exhibited a range in values similar to the $50-150 \mu \mathrm{m}$ size class, and 


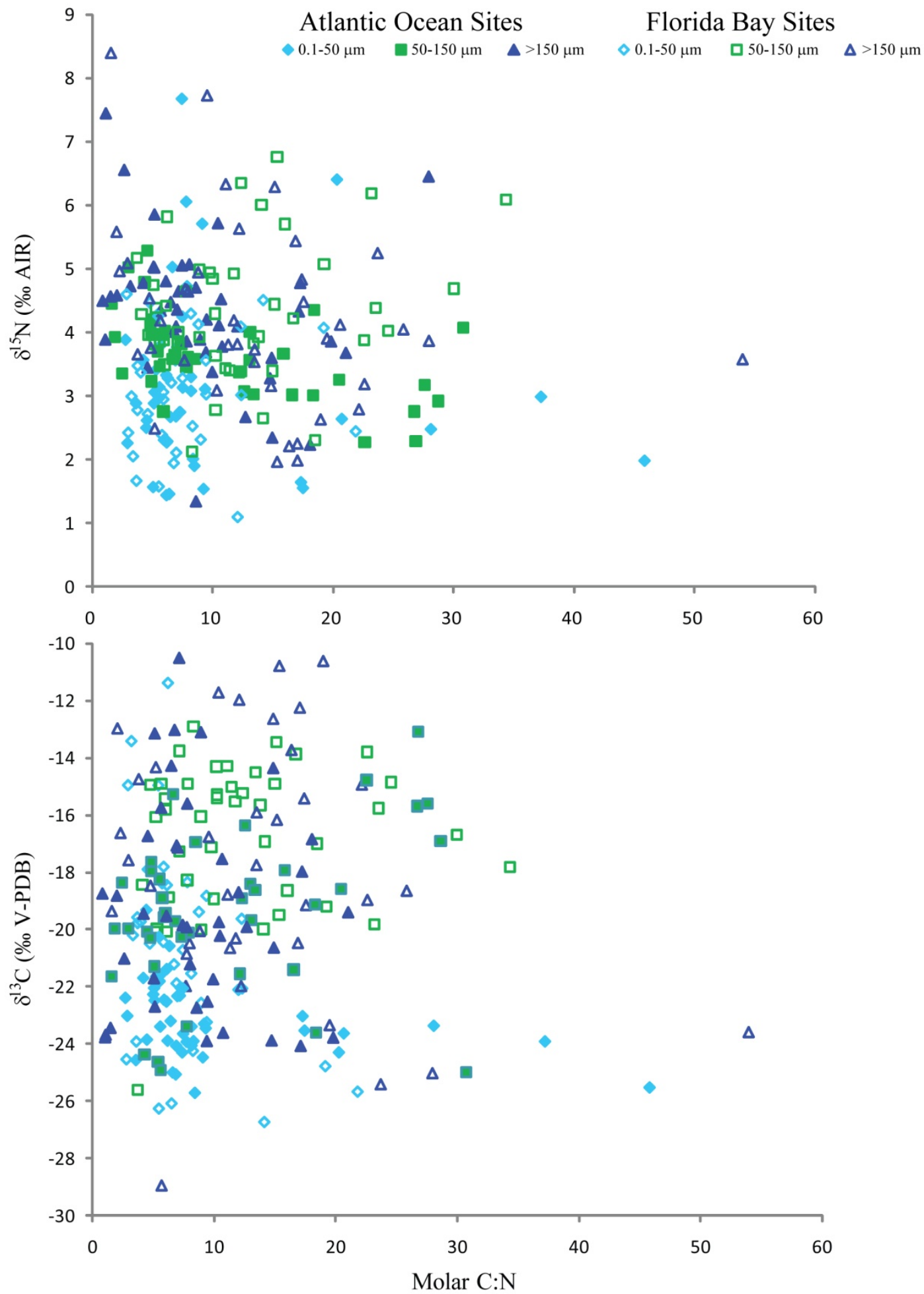

Figure 3.13 Bivariate plots of $\delta^{13} \mathrm{C}$ and $\delta^{15} \mathrm{~N}$ with Molar $\mathrm{C}: \mathrm{N}$ ratio for the three size fractions. 0.1-50 $\mu \mathrm{m}$ is shown with diamonds, $50-150 \mu \mathrm{m}$ is shown with squares, $>150 \mu \mathrm{m}$ is shown with triangles. Open symbols denote Florida Bay sampling sites, closed symbols represent Atlantic Ocean sites. 
also showed a similar trend toward more dispersed values in the Florida Bay pooled sites in terms of both isotopic and molar $\mathrm{C}: \mathrm{N}$ ratio values.

Figures 3.14 and 3.15 display populations of eukaryotic algae and cyanobacteria from the $0.1-50 \mu \mathrm{m}$ size fraction in flow cytometry analysis panes. Figure 3.14 shows sampling intervals from 2004 from the Atlantic Ocean sites, whereas Figure 3.15 depicts populations at the Florida Bay locations over the same period. Each point on the individual plots represents a single particle detection, thus darker areas indicate higher particle densities. A high degree of spatial and temporal variability is evident between sites and over the course of the four quarterly sampling intervals shown with large populations of Synechococcus sp., Prochlorococcus sp., and likely other cyanobacterial groups fluctuating in abundance over time. Eukaryotic algae are always present at much lower abundances than the cyanobacterial populations, yet also show variation in abundance over time.

\subsection{DISCUSSION}

Several studies of seasonal isotopic changes in size fractionated particulate organic material have demonstrated high levels of temporal variability. Wainright and Fry (1994) documented seasonal variation in $\mathrm{POM}-\delta^{13} \mathrm{C}$ of $>6 \%$, while $\delta^{15} \mathrm{~N}$ variability was $>5 \%$ in coastal New England over the course of two summer phytoplankton bloom periods. Seasonal variations measured in size fractionated POM from the Baltic Sea were of a similar magnitude, showing overall seasonal change of 5-7\%o through the course of the summer productivity season (Rolff 2000). Sato et al. (2006) illustrated even larger 

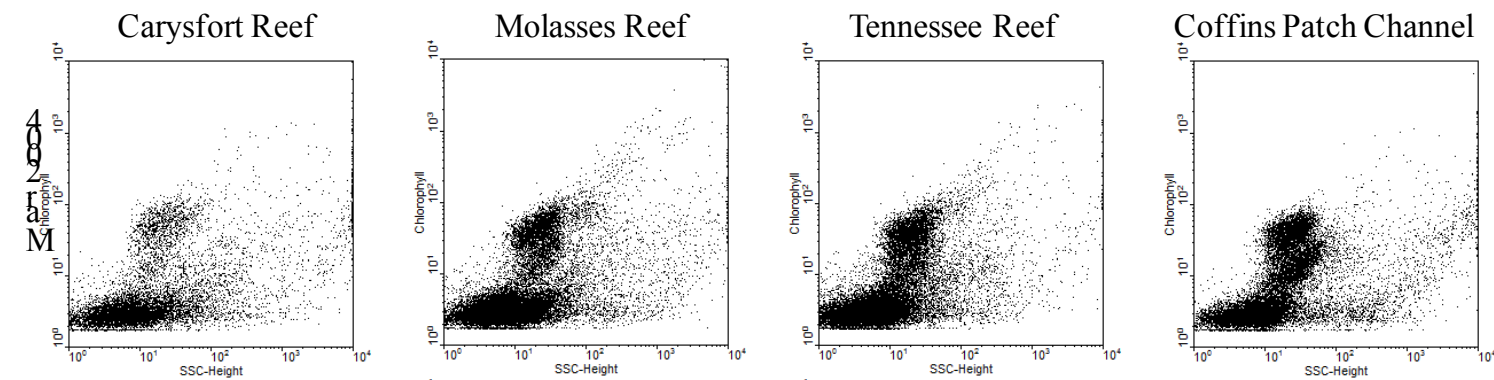

Bahia Honda Channel
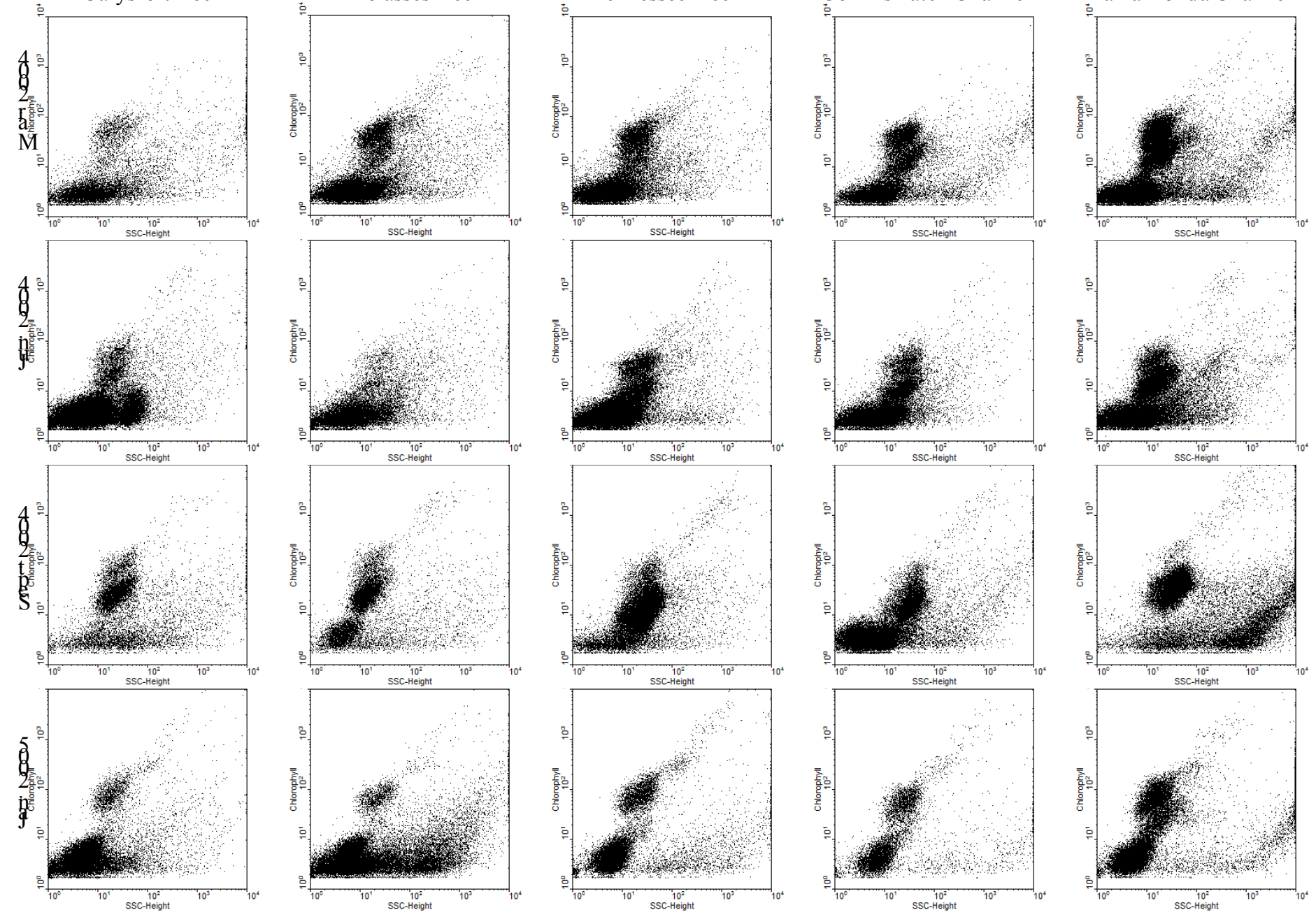

Figure 3.14 Flow cytometry analyses of Florida Keys Reef Tract phytoplankton collected quarterly at 5 stations along a N-S transect down the Florida Keys. 50000 events are displayed after acquisition in log mode. Chlorophyll- $a$ autofluorescence is plotted against side angle light scatter. 

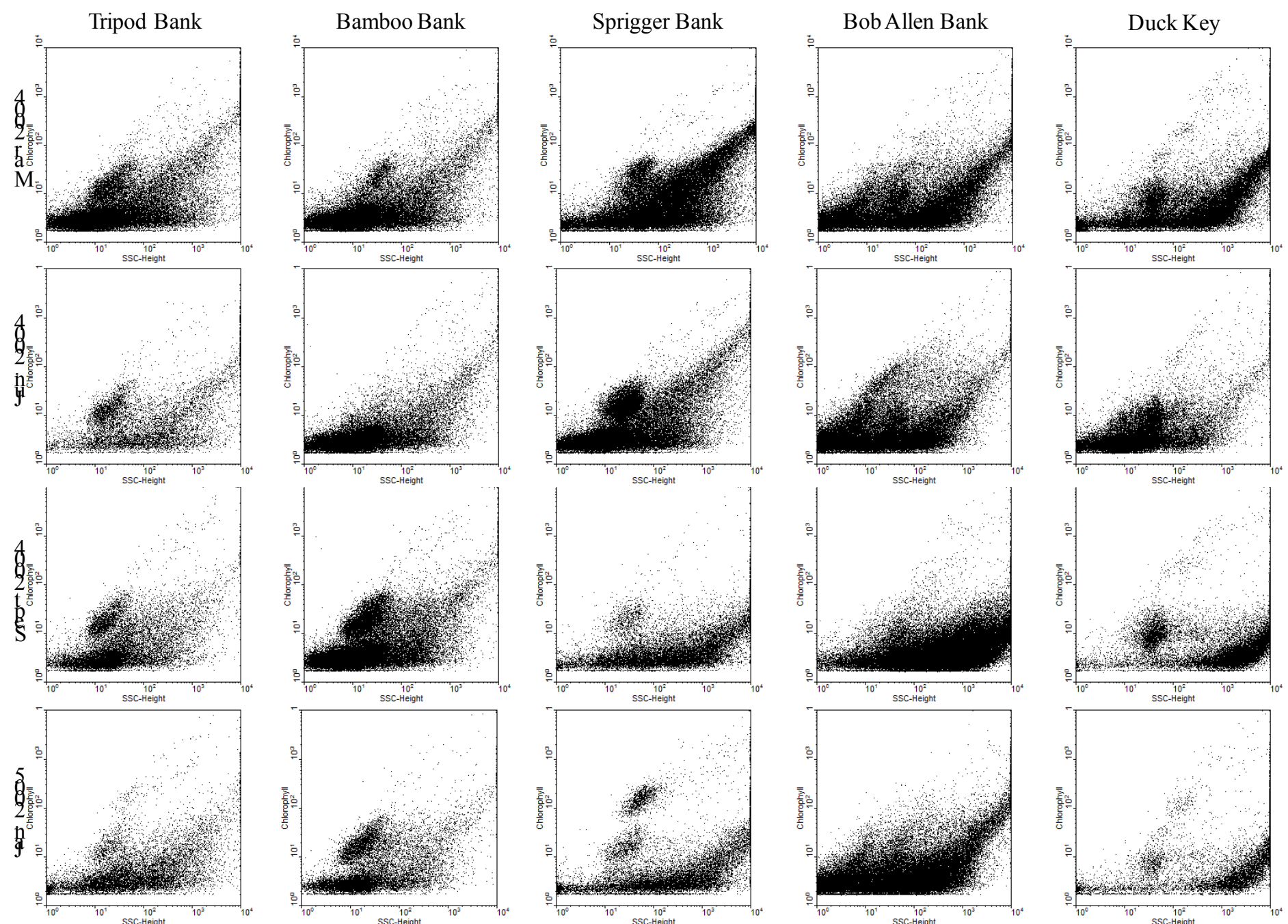

Figure 3.15 Flow cytometry analyses of Florida Bay phytoplankton collected quarterly at 5 stations in the bay. 50000 events are displayed after acquisition in log mode. Chlorophyll-a autofluorescence is plotted against side angle light scatter. 
isotopic fluctuations on a seasonal basis in Tokyo Bay, with both $\delta^{15} \mathrm{~N}$ and $\delta^{13} \mathrm{C}$ values changing by up to $10 \%$ between winter and spring. All of these studies took place in temperate coastal environments with much higher seasonal variation in parameters such as temperature than the seasonal differences seen over the course of the year in South Florida, yet here we found seasonal fluctuations in POM isotopic composition of equal or greater magnitude. The $\delta^{13} \mathrm{C}$ values varied quarterly in Florida Bay sites by up to $20 \%$ with an average range of $8.46 \%$ across all size classes and sites measured. Nitrogen isotopic values exhibited annual fluctuations of up to $6.4 \%$ with an average range of $3.0 \%$ across all sites and size fractions. These variations are larger than the seasonal variation measured over a period of eight years in South Florida seagrass communities. The average seasonal change in the regionally dominant seagrass, Thalassia testudinum, is under $1 \%$ in terms of $\delta^{15} \mathrm{~N}$ and less than $2 \%$ in $\delta^{13} \mathrm{C}$ (Fourqurean et al. 2005, Anderson and Fourqurean 2003).

Similar to the results presented here, Xu and Jaffé (2007) showed large differences in organic biomarker proxies from POM samples distributed across Florida Bay and also between wet and dry seasons, indicative of changes in POM sources on both spatial and temporal scales. The high variability evident in the isotopic signature of POM from the South Florida coastal zone has significant geochemical implications. Isotopic values are often applied in food-web studies that examine basal trophic levels or trace carbon flow in various environments. Inadequate understanding of the variability of POM isotopic values undermines the assumptions upon which such studies are based. Nitrogen isotopic variability has been invoked as a recorder of anthropogenic sewage pollution in the coastal zone (Lapoionte and Clark 1992, Lapointe et al. 2004, Ward- 
Paige et al. 2005, Lapointe et al. 2005); however, values of $>8 \%$ were recorded in this study in areas far from anthropogenic sewage sources, with a very low likelihood of such contamination. Furthermore, studies examining water column and water-sediment interface nitrogen cycling processes such as denitrification and nitrification often utilize bulk POM isotopic measurements to examine evidence of nitrogen recycling. The high levels of variability in isotopic signals over the two year period examined here suggests that annual variations must be taken into account in order to accurately apply isotopic data to evaluate ecological and geochemical processes.

\subsubsection{Temporal variability and hydrodynamic regime}

Within the large range of isotopic values measured for POM through the course of this two-year dataset, is a high level of spatial heterogeneity observed in quarterly trends. The studies of Wainright and Fry (1994), Rolff (2000), and Sato et al. (2006) were all limited in scope to a few (1-3) sampling stations in their respective localities, which were then taken to be representative of the local coastal system. In the dynamic coastal system of South Florida, even sampling locations close to one another may show significant variability in absolute isotopic values and in the seasonal patterns exhibited in those values over time. Both the northern Key Largo reef sites showed isotopic enrichments in successive January sampling events with ensuing isotopic depletions in June samples.

Sites in the Middle Keys sites, Tennessee Reef, Coffins Patch Channel, and Bahia Honda Channel, while still located along the Florida Keys Reef Tract, exhibited the opposite trend, with depleted isotopic values in both $\delta^{13} \mathrm{C}$ and $\delta^{15} \mathrm{~N}$ observed in January while enriched values were measured in summer quarter samples. In fact, the Middle Keys 
sites exhibited annual trends more similar to those at Western Florida Bay sites than to the more northern Key Largo reef sites. By far the greatest isotopic variability was found in the axial Florida Bay transect sites, Duck Key, Bob Allan Bank, and Sprigger Bank, which also exhibited quarterly trends out of phase with all other sites. Whereas the other site groupings showed variability between summer and winter samplings (January versus June), the Florida Bay sites showed the most significant depletions in the fall sampling intervals.

All of the differences in POM isotopic trends observed may be understood in terms of hydrodynamic regime at different areas in the south Florida coastal zone (Figure 3.16). The northern reef sites are located offshore of one of the longest land stretches in the Florida Keys - Upper Key Largo, and so have limited connectivity with the adjacent Florida Bay system. Nutrient sources to the Florida Keys reefs have been the subject of ongoing study (Leichter et al. 2008, Leichter et al. 2007, Leichter et al. 2003, Lapointe and Clark 1992, Lapointe et al. 2005 and others) and it has been well established that high frequency tidal upwelling represents a significant widespread, yet episodic, source of high nitrate and phosphate fluxes on Florida Keys Reef slopes. A significant pool of dissolved nutrients exists below the thermocline seaward of the Florida Keys Reef Tract

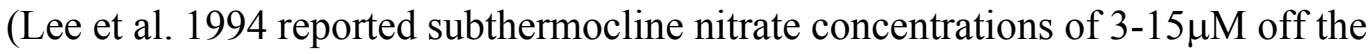
southern Florida Keys), and this transiently upwelled nutrient source impacts the reef crest environment and may be advected into back reef environments (Lee et al. 1994, Leichter et al. 2003, Smith et al. 2004). Episodic upwelling has been shown to be a predominantly summer phenomenon, when stratification at the thermocline is most pronounced as surface temperatures increase (Leichter et al. 2003). The isotopic 


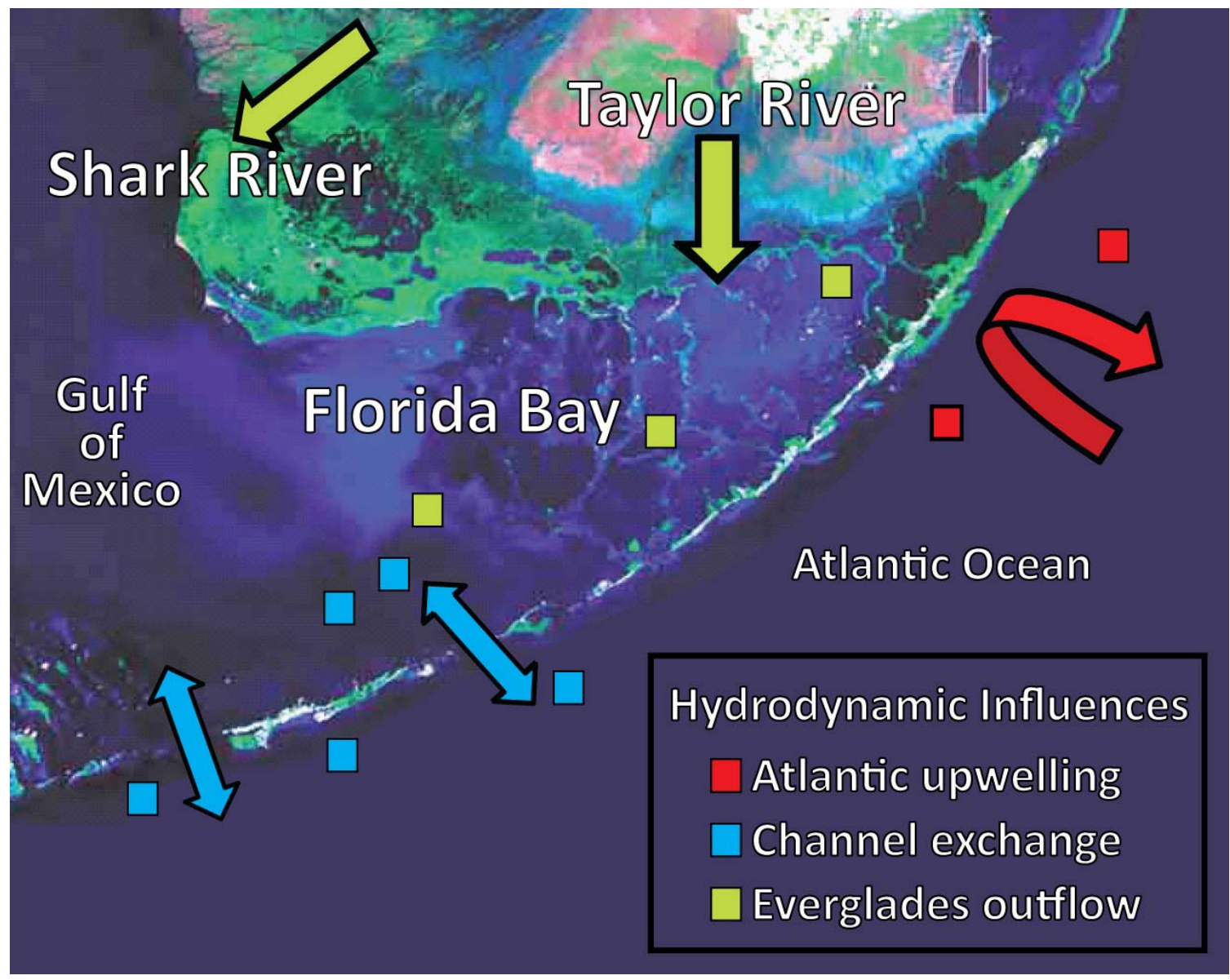

Figure 3.16 Conceptual model illustrating the distribution of South Florida coastal hydrodynamic zones as they influence nutrient dynamics and POM isotopic composition over time.

depletion trends evident in June sampling intervals at the northern reef sites correspond to increased SRP and DIN availability and also to increased population densities in cyanobacteria (Figure 3.14). Higher levels of DIN become available during the summer in the reef zone due to deeper water upwelling events and this influx of nutrients supports higher cyanobacterial densities, which in turn have been shown to fractionate carbon isotopes to a higher degree than other marine planktonic organisms (Wainright and Fry 1994). Additionally, under the nutrient replete conditions furnished by upwelling events, nitrogen isotopic fractionation could be expected to alter the $\delta^{15} \mathrm{~N}$ of the upwelled nitrate during assimilation processes, producing POM isotopic values of 2-3\%o as seen in the 
summer isotopic depletions $\left({ }^{15} \mathrm{NO}_{3}{ }^{-}\right.$measured seaward of the Florida Keys Reef Tract (Leichter et al. 2007) exhibits $\delta^{15} \mathrm{~N}$ values of 3.5-5.5\%). Similar isotopic values have been observed in deep water algal samples known to be influenced by the same subthermocline nutrient sources (Leichter et al. 2008).

The Middle Keys sites, Tennessee Reef, Coffins Patch Channel, and Bahia Honda Channel are located proximal to large channels crossing the Florida Keys (Channels 2 and 5, and Moser Channel/Seven-Mile Bridge). The channels connect these sites to the western Florida Bay sites at Tripod and Bamboo Banks. Exchange of water through tidal channels connecting the Gulf of Mexico and Atlantic sides of the Florida Keys is an important feature of the regional circulation (Smith 1998, Gibson et al. 2008). Gibson et al. (2008) demonstrated a net discharge of water and nutrients through Long Key Channel from Florida Bay to the Florida Keys National Marine Sanctuary; thus it is unsurprising that POM sampled on either side of such transport channels would be related in terms of geochemical characteristics and temporal variations. The channel sites all show marked differences from the outer reef sites, with depleted isotopic values evident in both carbon and nitrogen in January sampling intervals, and enriched summer signals observed in successive June samplings. More than one factor may influence these fluctuations. First, flow cytometry analyses (Figure 3.14, Tennessee Reef and Bahia Honda Channel) reveal much lower concentrations of detritus material in samples collected in January, and fairly pure cyanobacterial populations in these samples. While the isotopic values are not sufficiently depleted to demonstrate nitrogen fixation as a dominant process, high levels of cyanobacteria may be related to some level of nitrogen fixation, as shown in previous studies (Evans et al. 2006, Glibert et al. 2004, Phlips and Badylak 1996). Alternatively, 
enriched nitrogen isotopic values at the channel-associated sites in spring and summer sampling events may reflect surface nutrient utilization, as these time periods exhibited much higher population densities of cyanobacteria (Figure 3.14) in the $0.1-50 \mu \mathrm{m}$ size fraction and of diatoms in the $50-150 \mu \mathrm{m}$ size fraction. While it is possible that the cyanobacteria populations evident could contribute some or all of their nitrogen requirements through the $\mathrm{N}$-fixation metabolic pathway, coincident diatom populations are not capable of generating bioavailable nitrogen through fixation and thus are dependent on surface nutrient availability. Western Florida Bay is at the nitrogen-limited end of the nitrogen-phosphorus limitation gradient (Boyer et al. 1997). Under high primary productivity conditions, classic Rayleigh fractionation with depletion of surface nutrient pools would lead to gradual isotopic enrichment in both residual nutrient pools and in planktonic algae subsequently accessing these pools during photosynthesis.

The axial Florida Bay sites, Sprigger Bank, Bob Allen Bank, and Duck Key, display the most variable quarterly isotopic changes, with $\delta^{15} \mathrm{~N}$ ranges of up to $4 \%$ and $\delta^{13} \mathrm{C}$ ranges of up to $20 \%$. While the $20 \%$ change in $\delta^{13} \mathrm{C}$ likely reflects a transient contribution of terrestrial organic material at Sprigger Bank, $10 \%$ variations were seen in all three Florida Bay sites. Florida Bay annual trends in POM isotopic values differed from the other hydrodynamic regions discussed above. Rather than enrichment-depletion trends occurring in January or June, The Florida Bay sites showed repetitive $\delta^{15} \mathrm{~N}$ depletions in the fall/September sampling intervals. At Sprigger Bank this depletion trend was evident in all size classes, whereas at the other more northeastern sites, the trend was exhibited only by the $50-150 \mu \mathrm{m}$ phytoplankton size fraction. The depletion 
trend was most pronounced at Duck Key, the most northeasterly location, proximal to the Taylor River discharge from the Everglades, suggesting that this site might be significantly influenced by wet-season storm events, or by pre-storm freshwater discharge through Everglades flood control structures modulated by the South Florida Water Management District. The northeast subregion of the Florida Bay receives approximately $75 \%$ of the direct freshwater runoff to the bay through a series of small

creeks draining Taylor Slough (Lee et al. 2008). Most of this runoff is retained within the region due to weak interbasin exchange that is largely controlled by local east-west wind forcing (Nuttle et al. 2000, Lee et al. 2008). It is not unexpected then that this region, with a much longer water residence time than other areas of the South Florida coastal zone, should show anomalous isotopic trends. Although the trends are perhaps most apparent in the isolated Northeastern zone in Florida Bay, Shark River Slough discharge is carried by the Florida Loop Current along the western boundary zone of Florida Bay, crossing Sprigger Bank during this transport directly toward the middle Keys channels (Brand 2002). Thus freshwater outflow from Shark Slough may significantly impact and/or contribute particulates to the area surrounding Sprigger Bank.

\subsubsection{POM isotopic variability and water quality parameters}

The South Florida Coastal zone is partitioned by geomorphological features and varied current and freshwater flow regimes. Quarterly POM data support the importance of hydrodynamic regime in controlling geochemistry, with definite differences in temporal patterns between reef, channel, and Florida Bay locations. However, while this study yields a statistically valid description of seasonal changes in POM geochemical 
attributes in the unique environments of Florida Bay and the Florida Reef Tract, it was less suited to correlative analyses between the isotopic cycles within or between the size classes, or between the size classes and various environmental parameters potentially affecting them. Correlation requires high frequency sampling and an evenly spaced representation along a given physical or chemical gradient. Cyclic phenomena such as seasonal productivity cycles and nutrient drawdown lead to high variability and chaotic patterns in bivariate phase plots, and correlations may be undermined by even small lags in variables and related responses (Rolff 2000, Savoye et al. 2003). Correlations may also be flawed if the driving mechanisms controlling isotopic variability, such as nutrient source and availability or primary productivity levels, are not constant throughout the year. Strong seasonal drivers may be isolated in space and time, particularly in a system with an extreme dichotomy between wet and dry season patterns of rainfall and nutrient delivery. As a result, there are few direct correlations among isotopic values in POM size classes and environmental parameters, even while ambient seasonal nutrient availability does in fact exert influence over particulate isotopic composition.

In Northeastern Florida Bay, salinity and nutrient fluxes are largely controlled by seasonal Everglades outflows and direct rainfall inputs to the surface of Florida Bay itself (Nuttle et al. 2000, Rudnick et al. 1999, Boyer et al 1997), with modern water management practices favouring pulsed freshwater release during flooding stages (Rudnick et al. 1999), these drivers significantly affect isotopic signals in POM. This is the only region where statistical correlations between water quality and POM isotopic parameters were evident. Figure 3.7 shows a $4 \%$ negative excursion in the $\delta^{15} \mathrm{~N}$ value of the Duck Key phytoplankton associated size class $(50-150 \mu \mathrm{m})$. This isotopic depletion is 
coincident with a three-fold increase in ambient phosphorus concentration, and a two-fold increase in chlorophyll- $a$ concentration, unaccompanied by any significant change in the concentrations of dissolved nitrogen species. SRP concentration has been cited as one of the dominant factors responsible for stimulation of cyanobacterial bloom events (Phlips and Badylak 1996, Glibert et al. 2004, Janssen et al. 2004). Previous studies have reported high abundances of the cyanobacterium genus Synechococcus in Northeastern Florida Bay (Evans et al. 2006, Lavrentyev et al. 1998, Phlips and Badylak 1996), the most phosphorus-limited sector of the bay (Fourqurean et al. 1993, Boyer et al. 1997), supporting conclusions that this genus is an opportunistic phosphorus scavenger with euryhaline salinity tolerance (Stockner 1988). Depleted nitrogen isotopic values at both Duck Key in northeastern Florida Bay and also at Bob Allen Key in central Florida Bay in the September 2004 sampling suggest the potential for a phosphorus stimulated bloom originating in the northeast and being transported perhaps into central Florida Bay. Synechococcus has been shown to exhibit the capability for nitrogen-fixation (Phlips and Badylak 1996, Church 2005), so a mixture of POM containing both bloom organisms and particulates from more enriched sources could account for the $4 \%$ excursion found in this size fraction. Alternatively, with the pulse in phosphorus availability, a stimulated bloom would draw on the abundant inorganic nitrogen resources delivered in Everglades discharge. This inorganic nitrogen, postulated to originate from the upstream Everglades Agricultural area, might be isotopically light due to mineral fertilizer inputs.

\subsubsection{Florida Bay versus Atlantic Ocean pooled site characteristics}

Although there were few statistically significant correlations between water 
quality parameters and POM isotopic values over time, there were significant differences between sites when entire isotopic time-series data sets were compared to one another. Inter-site differences were found in all POM size classes in both $\delta^{15} \mathrm{~N}$ and $\delta^{13} \mathrm{C}(\mathrm{p}>0.001)$ however, while Duck Key differed from all other sites $(\mathrm{p}<0.001)$, other significant differences were rare and randomly distributed among site pairings, essentially reflecting the difference between Florida Bay and Atlantic Ocean sites in spite of apparent connectivity in seasonal patterns between Western Florida Bay and the Mid-Keys channel sites.

While correlation between carbon and nitrogen isotopic values pooled in Florida Bay versus Ocean sampling sites was not evident in all size fractions, the separation between Bay and Ocean POM was evident in each size class (Figure 3.12). In the 0.1$50 \mu \mathrm{m}$ fraction, Florida Bay samples exhibited a wider range of $\delta^{13} \mathrm{C}$ signatures, reflecting more estuarine inputs of particulate detritus from mangrove and seagrass organic material or an assemblage of cyanobacteria and picoplankton dependent on a broad range of decomposition product carbon sources. In this size fraction the ocean sites showed more restricted carbon isotopic compositions, with values characteristic of marine planktonic sources. In the $50-150 \mu \mathrm{m}$ size class there was a significant negative correlation between carbon and nitrogen isotopic values, as well as a notable separation between Bay and Ocean sites. Florida Bay POM in this fraction was more enriched than that in the Oceanside sites in terms of both $\delta^{15} \mathrm{~N}$ and $\delta^{13} \mathrm{C}$ values. In the case of the $\delta^{15} \mathrm{~N}$, this is inconsistent with the contention that the Florida Keys Reef Tract is under the influence of anthropogenic sewage pollution related to the Florida Keys population (Lapointe and Clark 1992, Lapointe et al. 2004, Ward-Paige et al. 2005). These results support those of 
Swart (2000) and Lamb (2006), in which extensive studies of nitrogen isotopic systematics along the Florida Reef tract showed no anomalous enrichments that could be unequivocally interpreted as evidence of sewage inputs to the reef setting. It is similarly unlikely that sampling locations along the central axis of Florida Bay were/are influenced by anthropogenic sewage contamination, yet the Florida Bay sites demonstrated a 3\% enrichment over the pooled ocean sites. Duck Key showed the highest enrichments overall in nitrogen isotopic composition, which may reflect isotopic enrichment of nitrogen sources due to denitrification in anoxic mangrove sediments, which are then carried into Northeastern Florida Bay via Everglades freshwater discharge. With the exception of a few depleted Florida Bay samples, the ocean samples showed a wider range in $\delta^{13} \mathrm{C}$ values, with a large number of values depleted by up to $6 \%$ relative to those found in Florida Bay.

Several early POM studies demonstrated a strong positive correlation between $\delta^{13} \mathrm{C}$ and $\delta^{15} \mathrm{~N}$ measurements on marine sedimentary particulates (Peters et al. 1978, Macko 1983, Wada et al. 1987). These correlations were interpreted as the result of mixing of terrestrial and marine organic matter, with terrestrial material having significantly more depleted isotopic values than marine material. The negative correlations evident in POM samples collected in the present study belie this simple mixing model in the South Florida coastal system. In addition, if terrestrial/marine organic matter mixing were to explain the isotopic variations observed, concurrent shifts would be observed in $\mathrm{C}: \mathrm{N}$ ratios of the samples (with the terrestrial material contributing much higher $\mathrm{C}: \mathrm{N}$ values), and a significant negative correlation between isotopic values and $\mathrm{C}: \mathrm{N}$ ratios would be expected. In the present study, there was no significant 
correlation between isotopic values and $\mathrm{C}: \mathrm{N}$ ratios (Figure 3.13). In fact, very few samples contained organic material exhibiting $\mathrm{C}: \mathrm{N}$ ratios characteristic of terrestrial organic matter. Most of the $\mathrm{C}: \mathrm{N}$ ratios measured for the different size classes of POM were marine in character $(<10)$, with a second grouping falling in the $10-30$ value range, similar to the values measured for seagrasses (Fourqurean and Escorcia 2007). The separation between Florida Bay and ocean site POM was also evident in differences in $\mathrm{C}: \mathrm{N}$ ratios, with the Florida Bay samples containing higher proportions of seagrass associated particles.

Further analysis comparing isotopic values to the logarithm of biomass (water column chlorophyll-a) demonstrated that the isotopic separation between Florida Bay and Ocean sites may be related to growth rates in the phytoplankton component of POM (Figure 3.17). Sato et al. (2006) illustrated that growth rate may be defined as the timederivative of logarithmic Chlorophyll- $a$, finding significant positive correlations between this index of growth rate and the $\delta^{13} \mathrm{C}$ values of POM. Their results suggest that decreases in isotopic discrimination or inducement of an $\mathrm{HCO}_{3}{ }^{-}$uptake mechanism are coincident with increases in growth rate (Sato et al. 2006). The 50-150 $\mu \mathrm{m}$ POM fraction observed in the present study also showed a significant positive correlation between $\delta^{13} \mathrm{C}$ and Log Chl- $a(\mathrm{R}=0.324, \mathrm{p}=0.05)$ in the phytoplankton size class $(50-150 \mu \mathrm{m})$, implying a dependence of isotopic discrimination on growth rate. Furthermore, higher growth rates were coincident with more enriched values in both $\delta^{13} \mathrm{C}$ and $\delta^{15} \mathrm{~N}$, with the effect more pronounced in Florida Bay than at Ocean sites. The difference between Florida Bay and Ocean side sites reflects differences in species assemblages from the two 

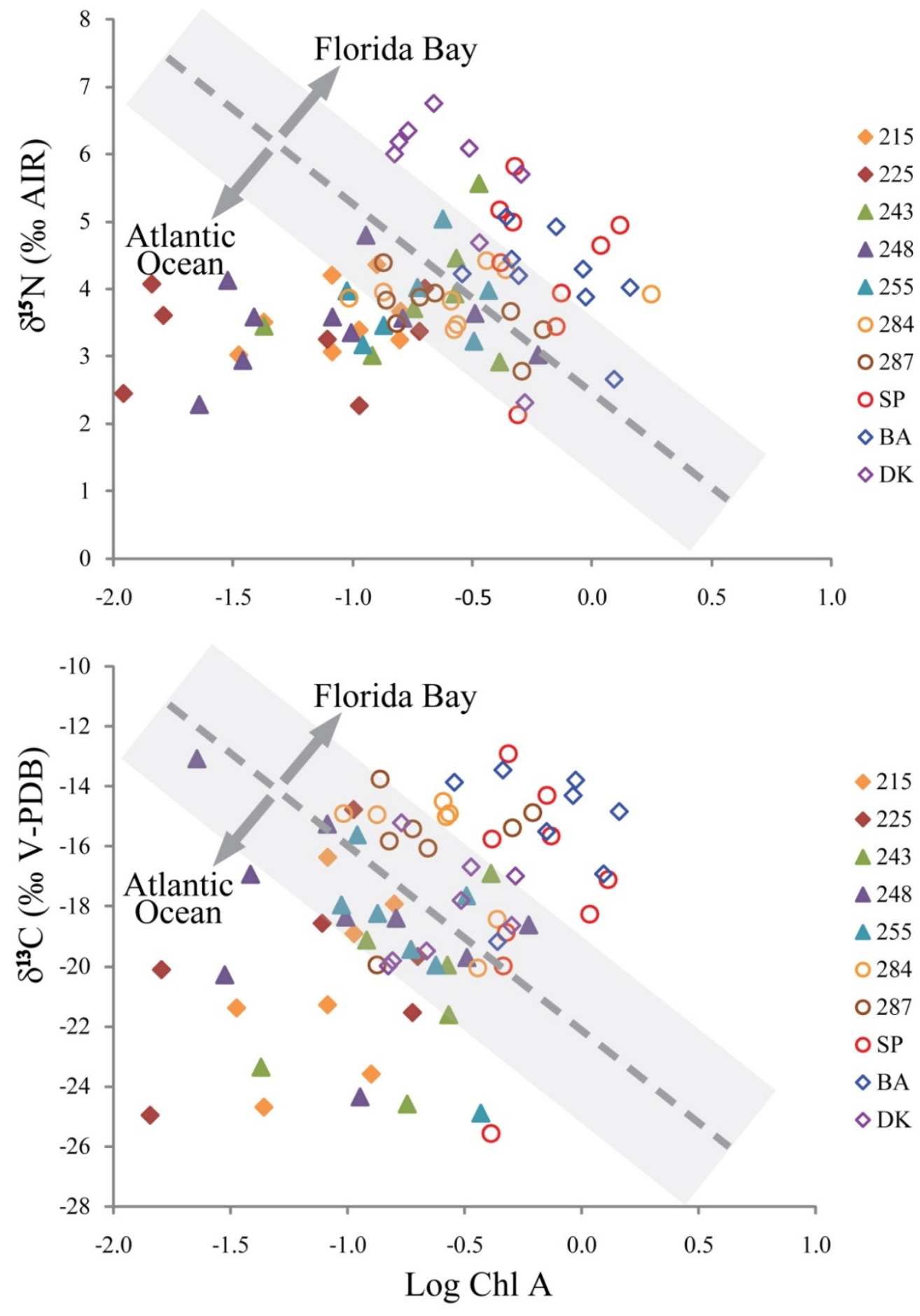

Figure 3.17 Bivariate plots of $\delta^{13} \mathrm{C}$ and $\delta^{15} \mathrm{~N}$ with Log Chlorophyll-a for the $50-150 \mu \mathrm{m}$ size fraction, dominated by autotrophic diatoms and dinoflagellates. Open symbols denote Florida Bay sampling sites, closed symbols represent Atlantic Ocean sites. The grey zone represents overlap between the Atlantic Ocean and Florida Bay groups in isotopic POM characteristics; this zone includes the Middle Keys channel sites. 
environments. Florida Bay $50-150 \mu \mathrm{m}$ was habitually dominated by a diverse diatom assemblage, with lower abundances of benthic foraminifera. Summer samplings documented a monospecific bloom of the dinoflagellate Protoperidinium, however this bloom was isolated at Bob Allen Bank. Atlantic Ocean sites, however, were predominately composed of dinoflagellates (dominated by several species of Ceratium) and both planktonic and benthic foraminifera (Appendix 4). The $>150 \mu \mathrm{m}$ size class did not show as clear a separation between Florida Bay and Ocean site samples, although the Florida Bay group showed a number of values enriched in terms of $\delta^{13} \mathrm{C}$, suggesting that some component of this size fraction is composed of seagrass detritus fragments.

These results, showing greater enrichments in both $\delta^{13} \mathrm{C}$ and $\delta^{15} \mathrm{~N}$ in Florida Bay samples in comparison with Atlantic Ocean site samples, with variance in enrichments between individual size fractions of POM, agree broadly with concurrent seagrass isotopic time series. Nitrogen isotopic values in seagrasses from the same ocean sites vary between 0 and $+6 \%$ over seasonal productivity cycles, while carbon isotopic values range between -12 and $-7 \%$. Florida Bay seagrass $\delta^{15} \mathrm{~N}$ seasonal signals vary from -2 to $+8 \%$, similar to the values seen in the POM. Seagrass carbon isotopic values do not show the same level of variation in comparison to the ocean sites as seen in the particulates, with values only showing slight enrichments relative to the ocean sites, ranging from -10 to -5\% (http://serc.fiu.edu/seagrass/!CDreport/DataHome.htm).

\subsubsection{Size fractionated sampling isotopic implications}

During the second year of POM sampling detailed here, bulk POM samples were collected for comparison with size separated samples (Figure 3.11). It is clear that the 
$\delta^{15} \mathrm{~N}$ values of bulk samples are highly susceptible to the influence of anomalous particles; in some comparisons, bulk values did not reflect those of any of the size classes, nor did they represent average values of combined size classes. Bulk filtered particulate samples from Lamb (2006) show carbon isotopic compositions that reflect a broad average of the $\delta^{13} \mathrm{C}$ variation found among size fractionated POM isotopic data (Figure 3.17). However, $\delta^{15} \mathrm{~N}$ results from both this study and that of Lamb (2006) show that bulk samples exhibit a very wide range of variability that does not consistently return the average nitrogen isotopic composition of size differentiated samples. Clear understanding of POM components is essential to accurately interpreting data. Size fractionated sampling allows at least broad classification of assemblage composition, which must be taken into account, along with temporal sample variation, in order to accurately apply isotopic data in the evaluation of ecological and geochemical processes.

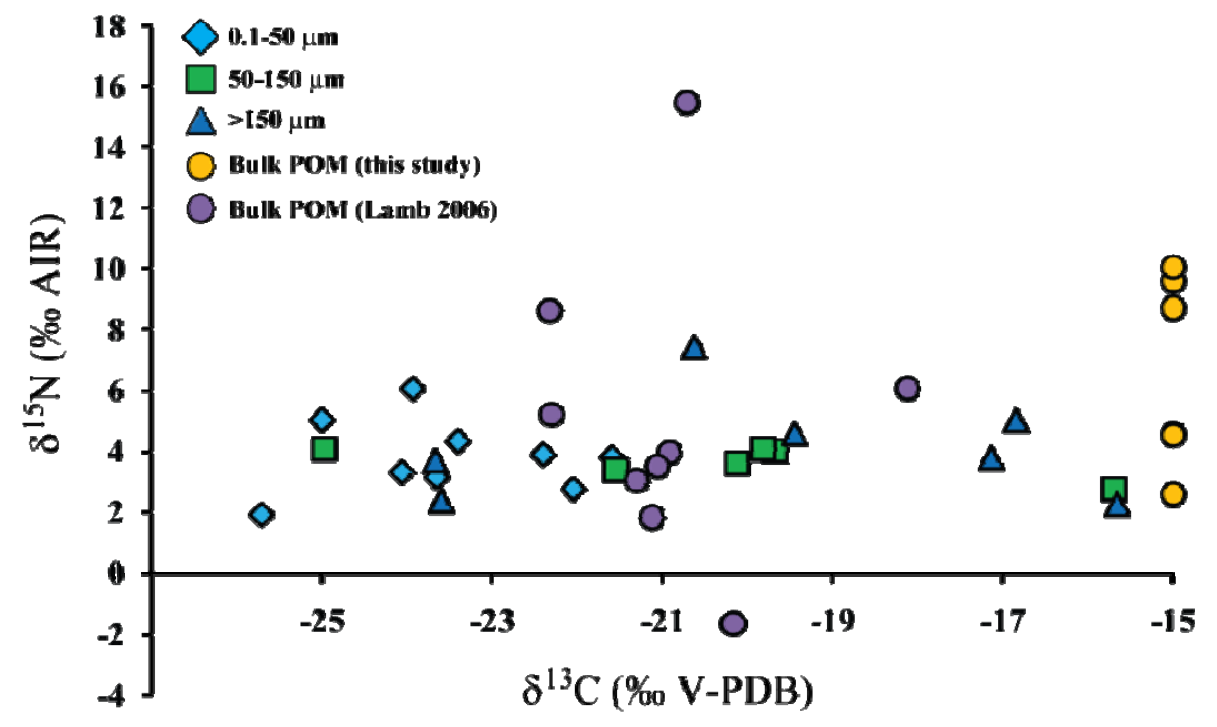

Figure 3.18 Isotopic values of size fractionated and bulk POM samples collected at Molasses Reef (this study) and Dixie Shoals (purple circles, Lamb 2006; collected in 2000-2002). Blue and green symbols represent size fractions and orange circles represent bulk samples collected concurrent with size fractions for $\delta^{15} \mathrm{~N}$ analysis only. 
In both $\delta^{15} \mathrm{~N}$ and $\delta^{13} \mathrm{C}$ values, and also in molar $\mathrm{C}: \mathrm{N}$ ratios, there were significant differences between the values of the three size fractions of POM. Among all sites within the Atlantic Ocean and Florida Bay groupings, the $0.1-50 \mu \mathrm{m}$ size fraction differed from both the larger size classes, the $50-150 \mu \mathrm{m}$ and $>150 \mu \mathrm{m}$ fractions. However, the two larger size classes did not generally differ significantly from each other, apparently due to the higher level of variability that was evident in the two larger size fraction isotopic signatures. Relationships in isotopic values between POM size classes from each site in which all three size fractions were present during sampling are shown in Figures 3.8 and 3.9. For the most part, the $0.1-50 \mu \mathrm{m}$ size class exhibited more depleted values than the other fractions in both $\delta^{13} \mathrm{C}$ and $\delta^{15} \mathrm{~N}$ values. Similar relationships were found in other size-separated POM studies (Rau et al. 1990, Wainright and Fry 1994, Rolff 2000). Wainright and Fry (1994) suggested that cyanobacteria exhibit higher isotopic fractionation during carbon fixation than other organisms to account for the depleted values. This would also seem to be the case for the South Florida coastal system as cyanobacteria populations appear to dominate the smaller size fraction measured in this study. Most studies have found evidence of trophic enrichment between increasing size classes in POM (Rau et al. 1990, Wainright and Fry 1994, Rolff 2000, Sato et al. 2006). Based on previous work evaluating food chain length in the temperate coastal system, Wainright and Fry (1994) anticipated that 4 trophic levels should be evident in size class samples, and that ensuing enrichments of 4 and $12 \%$ would be evident in $\delta^{13} \mathrm{C}$ and $\delta^{15} \mathrm{~N}$ POM of increasing size fraction. This was determined not to be the case; although carbon isotopic values did show the expected enrichment with size fraction, nitrogen 
isotopic values did not increase as significantly as anticipated. In the present study, maximum enrichments in terms of $\delta^{15} \mathrm{~N}$ values showed increases of approximately $5 \%$ across all size classes, with average increases of only $1.5 \%$ between adjacent size classes (Figures 3.9, 3.11). $\delta^{13} \mathrm{C}$ enrichments across size classes exceeded enrichment factors associated with trophic enrichments, with differences of up to $10 \%$ evident between size classes. These differences are not explained by food-web relationships as traditionally understood in higher level producers and consumers, but by differences in carbon isotopic fractionation during species specific productivity in the $0.1-50 \mu \mathrm{m}$ and $50-150 \mu \mathrm{m}$ size classes, and are perhaps influenced by variations in the sources of particulate detritus which also represents a significant portion of each size class. Alternatively, Wainright and Fry (1994) postulated that isotopic selectivity/trophic enrichment associated with microbial carbon and nitrogen uptake and release may be very different from, and perhaps more variable than that observed in higher metazoan communities.

\subsection{CONCLUSIONS}

Despite the importance of POM in aquatic ecosystems, studies of POM are hindered by several methodological constraints. One of the most important is that POM is heterogeneous, consisting of living and dead cells, fecal pellets, marine snow aggregates, organically coated mineral grains, and other materials. Each of these different types of POM may have different temporal and spatial variations in chemical composition, as well as different cycling times and ultimate fates in aquatic ecosystems. Separating particulates on the basis of size does not alleviate difficulties inherent in 
understanding the geochemical character of a variable mixture of particle sources, however size fractionation does allow some teasing apart of isotopic signal. This study has shown that there are significant differences among isotopic compositions of different size classes of POM, allowing a clearer understanding of particulate compositions and processes. Wide fluctuations were seen in seasonal patterns and in the responses of the separate size classes, indicating that composition of the size fractions is not simply a uniform amalgamation of detritus broken down to different particle sizes. Clearly planktonic communities respond to seasonal changes in environmental parameters, although driving mechanisms vary in space and time. In the case of the South Florida coastal zone, differences in all environmental parameters are dependent on the hydrodynamic regime of various areas in terms of geomorphological constraints and physical mechanisms of nutrient delivery and transport. Geochemical cycles in particulate organic material fractions reflect these patterns in hydrodynamic regime, showing seasonal patterns controlled by factors specific to particular zones of influence. The level of spatial and temporal variability, variability between size classes, as well as differences between size fractionated and bulk POM samples have implications for current assumptions regarding the interpretation of bulk filtered POM samples as they are applied to understanding food-web studies, studies of organic matter sources to the coastal zone, and natural tracer experiments examining anthropogenic influences in the coastal environment. All these studies must take into account spatial and temporal changes in the stable isotopic composition of POM when interpreting relationships and patterns. 


\section{LITERATURE CITED}

Altabet, M.A. 1988. Variations in nitrogen isotopic composition between sinking and suspended particles: Implications for nitrogen cycling and particle transformation in the open ocean. Deep-Sea Research 35:535-554.

Altabet, M.A., and R. Francois. 1994. Sedimentary nitrogen isotopic ratio as a recorder of surface ocean nutrient utilization. Global Biogeochemical Cycles 8:103-116.

Altabet, M.A., C. Pilskaln, R. Thunell, C. Pride, D. Sigman, F. Chavez, R. Francois. 1999. The nitrogen isotope biogeochemistry of sinking particles from the margin of the Eastern North Pacific. Deep Sea Research I 46:655-679.

Altabet, M.A. 2001. Nitrogen isotopic evidence for micronutrient control of fractional $\mathrm{NO}_{3}{ }^{-}$untilization in the equatorial Pacific. Limnology and Oceanography 46:368380 .

Anderson, W.T. and J.W. Fourqurean. 2003. Intra- and Interannual variability in seagrass carbon and nitrogen stable isotopes from South Florida, a preliminary study. Organic Geochemistry 34:185-194.

Battle, M., M.L. Bender, P.P. Tans, J.W. White, J.T. Ellis, T. Conway, R.J., Francey. 2000. Global carbon sinks and variability inferred from atmospheric $\mathrm{O}_{2}$ and $\delta^{13} \mathrm{C}$. Science 287:2467-2470.

Bentaleb, I., M. Fontugne, C. Descolas-Gros, C. Girardin, A. Mariotti, C. Pierre, C. Brunet, A. Poisson. 1998. Carbon isotopic fractionation by plankton in the Southern Indian Ocean: Relation between $\delta^{13} \mathrm{C}$ of particulate organic carbon and dissolved carbon dioxide. Journal of Marine Systems 17:39-58.

Boyer, J.N.; Fourqurean, J.W.; Jones, R.D. 1997. Spatial characterization of water quality in Florida Bay and Whitewater Bay by multivariate analyses: Zones of similar influence. Estuaries 20:743-758.

Brand, L. 2002. The transport of terrestrial nutrients to South Florida coastal waters. In: In: The Everglades, Florida Bay, and Coral Reefs of the Florida Keys: An Ecosystem Source Book. Eds: J.W. Porter and K.G. Porter. CRC Press, Boca Raton pp. 361-413.

Burkhardt, S., U. Riebesell, I. Zondervan. 1999. Effects of growth rate, $\mathrm{CO}_{2}$ concentration, and cell size on the stable carbon isotope fractionation in marine phytoplankton. Geochemica et Cosmochimica Acta 63:3729-3741. 
Church, M.J., B.D. Jenkins, D.M. Karl, J.P. Zehr. 2005. Vertical distributions of nitrogen-fixing phylotypes at Stn. ALOHA in the oligotrophic North Pacific Ocean. Aquatic Microbial Ecology 38:3-14.

Cifuentes, L.A., J.H. Sharp, M.L. Fogel. 1988. Stable carbon and nitrogen isotope biogeochemistry in the Delaware estuary. Limnology and Oceanography 33:11021115.

Cifuentes, L.A., R.B. Coffin, L. Solozano, W. Cardenas, J. Espinoza, R.R. Twilley. 1996. Isotopic and elemental variations of carbon and nitrogen in a mangrove estuary. Estuarine, Coastal, and Shelf Science 43:781-800.

Coffin, R.B., L.A. Cifuentes, P.M. Elderidge. 1994. The use of stable carbonisotopes to study microbial processes in estuaries. In: Lajtha, K., and R.H. Michener, eds. Stable Isotopes in Ecology and Environmental Science. Blackwell Scientific Publications, Oxford, UK. pp 222-240.

Descolas-Gros, C., and M. Fontugne. 1990. Stable carbon isotope fractionation by marine phytoplankton during photosynthesis. Plant Cell Environments 13:207-218.

Farquhar, G.D., M.H. O’Leary, J.A. Berry. 1982. On the relationship between carbon isotope discrimination and the intercellular carbon dioxide concentration leaves. Aust. Journal of Plant Physiology 9:121-137.

Fogel, M.L., and L.A. Cifuentes. 1993. Isotope fractionation during primary production. In: Engel, M.H. and S.A. Macko eds. Organic Geochemistry - Principles and Applications. Plenum Press, New York. pp 73-98.

Fourqurean, J.W., S.P. Escorcia, W.T. Anderson, J.C. Zieman. 2005. Spatial and seasonal variability in elemental content $\delta^{13} \mathrm{C}$ and $\delta^{15} \mathrm{~N}$ of Thalassia testudinum from South Florida and its implications for ecosystem studies. Estuaries 28:447-461.

Fourqurean, J.W., R.D. Jones, J.C. Zieman. 1993. Processes influencing water column nutrient characteristics and phosphorus limitation of phytoplankton biomass in Florida Bay, FL, USA: Inferences from spatial distributions. Estuarine, Coastal, and Shelf Science 36:295-314.

Fry, B. 1996. ${ }^{13} \mathrm{C} /{ }^{12} \mathrm{C}$ fractionation by marine diatoms. Marine Ecology Progress Series 134:283-294.

Fry, B., and E. Sherr. 1984. $\delta^{13} \mathrm{C}$ measurement as indicators of carbon flow in marine and freshwater ecosystems. Contributions to Marine Science 27:13-47. 
Evans, S.L., W.T. Anderson, F.J. Jochem. 2006. Spatial variability in Florida Bay particulate organic matter composition: Combining flow cytometry with stable isotope analysis. Hydrobiologia 569:151-165.

Gearing, J.N., P.J. Gearing, D.T. Rudnick, A.G. Roquejo, \& M.J. Hutchins. 1984. Isotopic variability of organic carbon in a phytoplankton-based, temperate estuary. Geochimica et Cosmochimica Acta 48:1089-1098.

Gearing, J.N. 1988. The use of stable isotope ratios for tracing the nearshore-offshore exchange of organic matter. In: Jansson, B.O. ed. Coastal-offshore Ecosystem Interaction. Lecture notes on Coastal and Estuarine Studies, Vol. 22. SpringerVerlag, Berlin. pp 69-101.

Gibson, P.J., J.N. Boyer, N.P. Smith. 2008. Nutrient mass flux between Florida Bay and the Florida Keys National Marine Sanctuary. Estuaries and Coasts 31:21-32.

Glibert, P.M., C.A. Heil, D. Hollander, M. Revilla, A. Hoare, J. Alexander, \& S. Murasko, 2004. Evidence for dissolved organic nitrogen and phosphorus uptake during a cyanobacterial bloom in Florida Bay. Marine Ecology Progress Series 280:73-83.

Hellings, L., F. Dehairs, M. Tackx, E. Keppens, W. Baeyens. 1999. Origin and fate of organic carbon in the freshwater part of the Schelde Estuary as traced by stable carbon isotope composition. Biogeochemistry 47:167-186.

Horrigan, S.G., J.P. Montoya, J.L. Nevins, J.J. McCarthy. 1990. Natural isotopic composition of dissolved inorganic nitrogen in the Chesapeake Bay. Estuarine, Coastal, and Shelf Science 30:393-410.

Janssen, F., T. Neumann, M. Schmidt. 2004. Inter-annual variability in cyanobacterial blooms in the Baltic Sea controlled by wintertime hydrogrphic conditions. Marine Ecology Progress Series 275:59-68.

Jochem, F.J. 2000. Probing the physiological state of phytoplankton at the single-cell level. Scientia Marina 64:183-195.

Korb, R.E., J.A. Raven, A.M. Johnston. 1998. Relationship between aqueous $\mathrm{CO}_{2}$ concentrations and stable isotope discrimination in the diatoms Chaetoceros calcitrans and Ditylum brightwellii. Marine Ecology Progress Series 171:303-305.

Lamb, K. 2006. Nitrogen cycling on coral reefs: A stable isotopic investigation of nutrient dynamics within the Florida Keys coral reef tract. Ph.D. Dissertation, University of Miami, $392 \mathrm{p}$. 
Lamb, K, and P.K. Swart. 2008. The carbon and nitrogen isotopic values of particulate organic material from the Florida Keys: a temporal and spatial study. Coral Reefs $27: 351-362$.

Lapointe, B.E., P.J. Barile, M.M. Littler, D.S. Littler. 2005. Macroalgal blooms on Southeast Florida Coral Reefs II. Cross-shelf determination of N-sources indicated widespread assimilation of sewage Nitrogen. Harmful Algae 4:1106-1122.

Lapointe, B.E., P.J. Barile, and W.R. Matzie. 2004. Anthropogenic nutrient enrichment of seagrass and coral reef communities in the Lower Florida Keys: Discrimination of local versus regional nitrogen sources. Journal of Experimental Marine Biology and Ecology 308:23-58.

Lapointe, B.E., and M.W. Clark. 1992. Nutrient inputs from the watershed and coastal eutrophication in the Florida Keys. Estuaries 15:465-476.

Lavrentyev, P.J, H.A. Bootsma, T.H. Johngen, J.F. Cavaletto, \& W.S. Gardner. 1998. Microbial plankton response to resource limitation: insights from the community structure and seston stoichiometry in Florida Bay, USA. Marine Ecology Progress Series 165:45-57.

Laws, E.A., B.N. Popp, R.R., Bidigare, M.C. Kennicutt, S.A. Macko. 1995. Dependence of phytoplankton carbon isotopic composition on growth rate and $\left[\mathrm{CO}_{2}\right]_{\mathrm{aq}}$ : theoretical considerations and experimental results. Geochimica et Cosmochimica Acta 59:1131-1138.

Laws, E.A., R.R. Bidgare, B.N. Popp. 1997. Effect of growth rate and $\mathrm{CO}_{2}$ concentration on carbon isotopic fractionation by the marine diatom Phaeodactylum tricornatum. Limnology and Oceanography 42:1552-1560.

Lee, T.N., N. Melo, E. Johns, C. Kelble, R.H. Smith, P. Ortner. 2008. On water renewal and salinity variability in the northeast subregion of Florida Bay. Bulletin of Marine Science 82:83-105.

Lee, T.N., M.E. Clarke, E. Williams, A.F. Szmant, T. Berger. 1994. Evolution of the Tortugas Gyre and its influence on recruitment in the Florida Keys. Bulletin of Marine Science 54:621-646.

Leichter, J.J., H.L. Stewart, S.L. Miller. 2003. Episodic nutrient transport to Florida coral reefs. Limnology and Oceanography 48:1394-1407.

Leichter, J.J., A.P. Paytan, S. Wankel, K. Hanson, S.L. Miller. 2007. Nitrogen and oxygen isotopic signatures of subsurface nitrate: evidence of deep water nutrient sources to the Florida Keys reef tract. Limnology and Oceanography 52:1258-1267. 
Leichter, J.J., M.D. Stokes, S.J. Genovese. 2008. Deep water macroalgal communities adjacent to the Florida Keys reef tract. Marine Ecology Progress Series 356:123138.

Loick, N., J. Dippner, H.N. Doan, I. Liskow, M. Voss. 2007. Pelagic nitrogen dynamics in the Vietnamese upwelling area according to stable nitrogen and carbon isotope data. Deep Sea Research I 54:596-607.

Macko. S.A. 1983. Sources of organic nitrogen in mid-Atlantic coastal bays and continental shelf sediments of the United States; isotopic evidence. Carnagie Institute of Washington, Annual Report of the Geophysical Laboratory 19821983:328-329.

Mahaffey, C., R.G. Williams, G.A. Wolff, N. Mahowald, W.T. Anderson, M. Woodward. 2003. Biogeochemical signatures of nitrogen fixation in the eastern North Atlantic. Geophysical Research Letters 30:33-36.

Mariotti, A., C. Lancelot, G. Billen. 1984. Natural isotopic composition of nitrogen as a tracer of the origin of suspended organic matter in the Scheldt estuary. Geochimica et Cosmochimica Acta 48:549-555.

Matson, E.A., and M.M Brinson. 1990. Stable carbon isotopes and the C:N ratio in the estuaries of the Pamlico and Neuse Rivers, North Carolina. Limnology and Oceanography 35:1290-1300.

McClelland, J.W., and I. Valiela. 1998. Linking nitrogen in estuarine producers to landderived sources. Limnology and Oceanography 43:577-585.

Middelburg, J.J., \& J. Nieuwenhuize, 2001. Nitrogen isotope tracing of dissolved inorganic nitrogen behaviour in tidal estuaries. Estuarine, Coastal, and Shelf Science $53: 385-391$.

Minor, E. C., P.S. Nallanthamby. 2004. "Cellular" vs. "detrital” POM: A preliminary analysis uding fluorescent stains, flow cytometry, and mass spectrometry. Marine Chemistry 92:9-21.

Montoya, J.P., and J.J. McCarthy. 1995. Isotopic fractionation during nitrate uptake by phytoplankton grown in continuous culture. Journal of Plankton Research 17:439464.

Needoba, J.A., N.A. Waser, P.J. Harrison, S.E. Calvert. 2003. Nitrogen isotope fractionation in 12 species of marine phytoplankton during growth on nitrate. Marine Ecology Progress Series. 255:81-91. 
Needoba, J.A., D.M. Sigman, P.J. Harrison. 2004. The mechanism of isotope fractionation during algal nitrate assimilation as illuminated by the ${ }^{15} \mathrm{~N} /{ }^{14} \mathrm{~N}$ of intracellular nitrate. Journal of Phycology 40:517-522.

Nuttle, W.K., J.W. Fourqurean, B.J. Cosby, J.C. Zieman, M.B. Robblee. 2000. Influence of net freshwater supply on salinity in Florida Bay. Water Resources Research 36:1805-1822.

Ogawa, N., N. Aoki, I. Kon, N, Ogura. 1994. Stable carbon isotope ratio of suspended particulate and sedimentary organic matter during the summer blooming in Tokyo Bay. Chikukagaku 28:21-36 (English summary)

Ogawa, N, and N. Ogura. 1997. Dynamics of particulate organic matter in the Tamagawa estuary and inner Tokyo Bay. Estuarine, Coastal, and Shelf Science. 44:263-273.

O’Leary, M.H. 1981. Carbon isotope fractionation in plants. Phytochemistry 20:553567.

Owens, N.J.P. 1987. Natural variations in ${ }^{15} \mathrm{~N}$ in the marine environment. Advances in Marine Biology 24:389-451,

Park, R., and S. Epstein. 1960. Carbon isotope fractionation during photosynthesis. Geochimica et Cosmochimica Acta 21:110-126.

Pennock, J.R., D.J. Velinsky, J.M. Ludlam, J.H. Sharp, M.L. Fogel. 1996. Isoptopic fractionation of ammonium and nitrate during uptake by Skeletonema costatum: Indications for $\delta^{15} \mathrm{~N}$ dynamics under bloom conditions. Limnology and Oceanography 41:451-459.

Peters, K.E., R.E. Sweeney, I.R. Kaplan. 1978. Correlation of carbon and nitrogen stable isotope ratios in sedimentary organic matter. Limnology and Oceanography 23:598-604.

Peterson, B.J. 1999. Stable isotopes as tracers of organic matter input and transfer in benthic food webs: a review. Acta Oecologia 20:479-487.

Phlips, E.J., S. Badylak. 1996. Spatial variability in phytoplankton sanding crop and composition in a shallow tropical inner-shelf lagoon, Florida Bay, USA. Bulletin of Marine Science 58:203-216.

Popp, B.N., E.A. Laws, R.R. Bidigare, J.E. Dore, K.L. Hanson, \& S.G. Wakeham, 1998. Effect of phytoplankton cell geometry on carbon isotopic fractionation. Geochemica et Cosmochemica Acta 62:69-77. 
Rau, G.H., J.L. Teyssie, F. Rassoulzadegan, S.W. Fowler. $1990 .{ }^{13} \mathrm{C} /{ }^{12} \mathrm{C}$ and ${ }^{15} \mathrm{~N} /{ }^{14} \mathrm{~N}$ variations among size-fractionated marine particles: Implications for their origin and trophic relationships. Marine Ecology Progress Series 59:33-38.

Rau, G.H., T. Takahashi, D.J. Des Marais, D.J. Repeta, H. Martin. 1992. The relationship between $\delta^{13} \mathrm{C}$ of organic matter and $\left[\mathrm{CO}_{2} \mathrm{aq}\right]$ in ocean surface water: data from a JGOFS site in the northeast Atlantic Ocean as a model. Geochimica et Cosmochimica Acta 56:1413-1419.

Riebesell, U., S. Burkhardt, A. Dauelsberg, B. Kroon. 2000. Carbon isotope fractionation by a marine diatom: dependence on the growth-rate-limiting resource. Marine Ecology Progress Series 193:295-303.

Rolff, C. 2000. Seasonal variation in $\delta^{13} \mathrm{C}$ and $\delta^{15} \mathrm{~N}$ of size-fractionated plankton at a coastal station in the northern Baltic proper. Marine Ecology Progress Series 203:47-65.

Rudnick, D.T., Z. Chen, D.L. Childers, J.N. Boyer, and D.T. Fontaine. 1999. Phosphorus and nitrogen inputs to Florida Bay: The importance of the Everglades watershed. Estuaries 22:398-416.

Sato, T., T. Miyajima, H. Ogawa, Y. Umezawa, I. Koike. 2006. Temporal variability of stable carbon and nitrogen isotopic composition of size-fractionated particulate organic matter in the hypertrophic Sumida River Estuary of Tokyo Bay, Japan. Estuarine, Coastal, and Shelf Science 68:245-258.

Savoye, N., A. Aminot, P. Treguer, M. Fontugne, N. Naulet, R. Kerouel. 2003. Dynamics of particulate organic matter $\delta^{15} \mathrm{~N}$ and $\delta^{13} \mathrm{C}$ during spring phytoplankton blooms in a macrotidal ecosystem Bay of Seine, France). Marine Ecology Progress Series 255:27-41.

Sigleo, A.C., and S.A. Macko. 2002. Carbon and nitrogen isotopes in suspended particles and colloids, Chesapeake and San Francisco estuaries, USA. Estuarine, Coastal, and Shelf Science 54:701-711.

Smith, N.P. 1998. Tidal and long-term exchanges through channels in the middle and upper Florida Keys. Bulletin of Marine Science 62:199-211.

Smith, J.E., C.M. Smith, P.S. Vroom, K.L. Beach, S. Miller. 2004. Nutrient and growth dynamics of Halimeda tuna on Conch Reef, Florida Keys: Possible influence internal tides on nutrient status and physiology. Limnology and Oceanography 49:1923-1936.

Stockner, J.G., 1988. Phototrophic picoplankton: an overview from marine and freshwater ecosystems. Limnology and Oceanography 33:765-775. 
Szmant, A.M. and A. Forrester. 1996. Water column and sediment nitrogen and phosphorus distribution patterns in the Florida Keys, USA. Coral Reefs 15:21-41.

Teranes, J.L., and S. Bernasconi. 2000. The record of nitrate utilization and productivity limitation provided by $\delta^{15} \mathrm{~N}$ values in lake organic matter - A study of sediment trap and core sediments from Baldeggersee, Switzerland. Limnology and Oceanography 45:801-813.

Thornton, S.F., and J. McManus. 1994. Application of organic carbon and nitrogen stable isotope and $\mathrm{C} / \mathrm{N}$ ratios as source indicators of organic matter provenance in estuarine systems: Evidence from the Tay estuary, Scotland. Estuarine, Coastal, and Shelf Science 38:219-233.

Umezawa, Y., T.Miyajima, M. Yamamuro, H. Kayanne, I. Koike. 2002. Fine scale mapping of land-derived nitrogen in coral reefs by $\delta^{15} \mathrm{~N}$ in macroalgae. Limnology and Oceanography 47:1405-1416.

Wainright, S.C. and B. Fry. 1994. Seasonal variation in the stable isotopic compositions of coastal marine plankton from Woods Hole, Massachusetts and Georges Bank. Estuaries 17:552-560.

Ward-Paige, C.A., M.J. Risk, O.A. Sherwood. 2005. Reconstruction of nitrogen sources on coral reefs: $\delta^{15} \mathrm{~N}$ and $\delta^{13} \mathrm{C}$ in Gorgonians from the Florida Reef Tract. Marine Ecology Progress Series 296:155-163.

Wada, E., M. Minagawa, H. Mizutani, T. Tsuji, R. Imaizumi, K. Karasawa. 1987. Biogeochemical studies on the transport of organic matter along the Ostuchi River Watershed, Japan. Estuarine, Coastal, and Shelf Science. 25:321-336.

Wada, E., and A. Hattori. 1991. Nitrogen in the Sea: Forms, abundances, and rate processes. CRC Press, Boca Raton, FL, USA.

Waser, N.A., P.J. Harrison, B. Neilsen, S.E. Calvert, D.H. Turpin. 1998. Nitrogen isotope fractionation during the uptake and assimilation of nitrate, nitrite, ammonium, and urea uptake by a marine diatom. Limnology and Oceanography 43:215-224.

Waser, N.A., Z. Yu, K. Yin, B. Neilsen, P.J. Harrison, D. Turpin, S.E. Calvert. 1999. Nitrogen isotopic fractionation during a simulated diatom spring bloom: importance of N-starvation in controlling fractionation. Marine Ecology Progress Series 179:291-296.

Waser, N.A., W.G. Harrison, E.J.H. Head, B. Neilsen, V.A. Lutz, S.E. Calvert. 2000. Geographic variations in the nitrogen isotope composition of surface particulate 
nitrogen and new production across the North Atlantic Ocean. Deep Sea Research I 47:1207-1226.

Xu, Y., and R. Jaffé. 2007. Lipid biomarkers in suspended particles from a subtropical estuary: Assessment of seasonal changes in sources and transport of organic matter. Marine Envieonmental Research 64:666-678. 
CHAPTER 4

STABLE ISOTOPE COMPOSITION OF SEDIMENTARY ORGANIC MATTER FROM FLORIDA BAY 


\subsection{ABSTRACT}

The shallow waters of Florida Bay represent an ideal environment for seagrasses, which are the most common benthic community in the region. Seagrass communities are, however, susceptible to a variety of anthropogenic disturbances, particularly changes in water quality. Environmental conditions in Florida Bay have become a concern due to recent increases in salinity, microalgal bloom frequency, and seagrass mortality. These changes have been attributed to 20th century decreases in freshwater discharge from the Everglades to Florida Bay, deteriorated water quality, and changes in exchange between the Bay and the Atlantic Ocean. In order to better understand environmental change over long time scales, sediment cores were collected in Summer 2002 from four locations in Florida Bay for multiple proxy analyses of seagrass abundance. Here bulk carbon and nitrogen stable isotope data are presented with sediment nutrient data from Trout Creek, Russell Bank, Bob Allen Bank, and Ninemile Bank.

The Trout Creek core, collected near the freshwater Everglades outflow of Taylor Slough had the most depleted average carbon isotopic value over time $(-19.64 \pm 0.62 \%)$ and the most enriched $\delta^{15} \mathrm{~N}$ values $(+5.65 \pm 0.0 .59 \%$ ). These values reflect higher inputs of terrestrial organic material (mangrove detritus) and freshwater particulates from the upstream Everglades ecosystem. All the remaining cores from central and western Florida Bay had mean $\delta^{13} \mathrm{C}$ values between $-11.61 \pm 0.72 \%$ and $-9.96 \pm 0.50 \%$, suggesting that seagrass is the dominant organic matter source in the open bay setting. Mean nitrogen isotopic values in central Florida Bay at Bob Allen and Russell Banks were $+4.16 \pm 0.42 \%$ and $+5.24 \pm 0.33 \%$ respectively, whereas the Ninemile Bank core 
had a more depleted average $\delta^{15} \mathrm{~N}$ value of $+2.22 \pm 0.43 \%$, possibly due to nitrogen inputs originally related to $\mathrm{N}$-fixation in the water column community.

Major events, both anthropogenic and naturally occurring, were evident in the Florida Bay cores, with pronounced shifts in first-order trends and an increase in isotopic variability coincident with the construction of Flagler's Railroad circa 1910, which resulted in decreased exchange between Florida Bay and the Atlantic Ocean. Further changes in the upstream Everglades drainage basin due to canal building circa 1947 also impacted the isotopic and elemental contents of the Florida Bay sedimentary record. In addition, all the major Category 4 and 5 hurricanes of the $20^{\text {th }}$ century to directly impact south Florida were evident in the sedimentary record. Hurricane impacts were most apparent in the sediments of Trout Creek, where Everglades discharge delivered pulses of terrestrial organic material coincident with major storm events.

\subsection{INTRODUCTION}

Human population growth in coastal areas has precipitated extensive alteration of the quality, quantity, and timing of freshwater runoff into estuaries. In many areas the major water quality change has been an increase in nutrient loading, causing eutrophication of many estuaries and coastal marine systems (Fourqurean et al. 2003). This eutrophication tends to cause shifts in relative dominance between planktonic primary producers and submerged aquatic vegetation, favouring planktonic bloom organisms. Further, marine macrophytes, such as seagrasses, which are prevalent under more oligotrophic conditions, have often been replaced by faster growing, opportunistic 
benthic macro- and micro-algae, and also phytoplankton, under conditions of increased anthropogenic nutrient loading (Fourqurean et al. 1993, Duarte 1995). In addition to cultural eutrophication, salinity changes resulting from engineering modifications to freshwater runoff storage and discharge may also influence the distribution and assemblage of submerged aquatic macrophyte communities.

Florida Bay, a $2200 \mathrm{~km}^{2}$ shallow subtropical lagoonal estuary, is one such ecosystem which has been affected by human activities over the past century. Canal and trans-Everglades road construction in the early to mid-1900's significantly reduced freshwater flow from the Everglades to Florida Bay via both Shark River and Taylor Sloughs, subsequently leading to increasing periods of hypersalinity in the bay (Smith et al. 1989, Davis and Ogden 1994, Rudnick et al. 1999). Prior to these water management changes however, channel infilling associated with railroad and road construction along the length of the Florida Keys in the early part of the century served to restrict oceanic exchange and circulation between Florida Bay and the Atlantic. These changes in freshwater discharge and circulation are clearly reflected in both fluorescence studies and carbon and oxygen isotopic analyses on coral skeleton cores from several Florida Bay basins (Smith et al. 1989, Swart et al. 1996, 2001).

More recently, over the past two decades, the ecological health of South Florida's coastal ecosystem has increasingly been called into question (McPherson and Halley 1996, Huvane and Cooper 2001, Rudnick et al. 2006). While historically the Florida Bay ecosystem is thought to have been a shallow, optically clear lagoon characterized by low nutrient levels and populated by abundant seagrass communities, in recent years significant declines have been observed in water clarity, hypersaline conditions have 
periodically developed in the summer months (Boyer et al. 1999), and widespread die-off events have occurred in benthic seagrass communities (Zieman et al. 1989, Fourqurean et al. 1993), coincident with phytoplankton blooms (Robblee et al. 1991, Butler et al. 1995, Phlips and Badylack, 1996). Since 2005, a massive cyanobacterial bloom has persisted in southern Biscayne Bay and Northeastern Florida Bay, yet the causes of the bloom remain uncertain (Rudnick et al. 2006). Although there has been growing concern that these biotic shifts are related to anthropogenic changes in Everglades flow and increasing nutrient inputs from the Florida Keys and the Gulf of Mexico, it is also questioned whether the changes are a consequence of natural phenomena, such as climatic fluctuation or ecological succession cycles (Lapointe and Clark 1992, McIvor et al. 1994, Lapointe et al. 1994, Swart et al. 1999). In the case of the Biscayne Bay - Florida Bay cyanobacteria bloom, the causal mechanisms may in fact be a combination of both anthropogenic and natural phenomena. The bloom is hypothesized to have been caused by the interaction of anthropogenic disturbance related to road construction along US-1 between Florida City and Key Largo with the particularly active hurricane season of 2005, both serving to deliver a large pulse of bioavailable nitrogen and phosphorus, stimulating algal growth (Rudnick et al. 2006). Throughout the inundation history of Florida Bay, it has represented a complex, dynamic ecosystem subject to temporal and spatial variations in environmental conditions (Brewster-Wingard et al. 1999). Prior to significant human impact on the bay, fluctuations in environmental parameters were controlled by natural forces, including hurricanes, climatic variations, and changing sea level. 
The Everglades Forever Act (1994) mandates that the ecosystem be returned to its "natural state"; a clear definition of the "natural state" of the Florida Bay ecosystem is thus pivotal to the implementation of restoration efforts. Paleoecological and paleoceanographic reconstructions have become increasingly important to these management decisions in the absence of long term monitoring data. Long term proxy records of environmental change, for example those found in coral skeletons (Smith et al. 1989, Swart et al. 1996, Swart et al. 1999) and those in sedimentary records (Halley and Roulier 1999, Brewster-Wingard and Ishman 1999, Brewster-Wingard et al. 2001, Huvane and Cooper 2001, Cronin et al. 2001, Xu et al. 2006, Xu et al. 2007), provide a baseline understanding of how the South Florida system has changed through time over the last 100 to 4000 years. Despite the growing body of paleoecological data, there remains a large degree of uncertainty about the ecosystem history of Florida Bay (Cronin et al. 2001). This study applies $\delta^{13} \mathrm{C}$ and $\delta^{15} \mathrm{~N}$ values with carbon, nitrogen, and phosphorus elemental compositions of bulk sedimentary organic matter as geochemical tracers in the sediment record over the last 150-200 years in an effort to examine recent environmental changes in Florida Bay, and to gain understanding of the system predating anthropogenic influences. Previous work employing these geochemical proxies, such as Orem et al. (1999) and Nelson et al. (2002), have been limited to a few select locations within Florida Bay and in the mangrove estuaries of the southwestern Everglades, and were completed at a lower sampling resolution that work presented here. 


\subsection{METHODS}

\subsubsection{Setting}

Florida Bay is a shallow, lagoonal estuary located between the southern tip of the Florida Peninsula and the Florida Keys. The bay has a surface area of approximately 2, $200 \mathrm{~km}^{2}$ and a mean depth of less than 2 meters (Fourqurean and Robbins 1999, Orem et al. 1999). Sediments have been accumulating in Florida Bay for more than 4000 years over a gradually sloping Pleistocene limestone surface that is 1-4 m below present sea level (Scholl 1964). Basal sediments comprising brackish and freshwater peats and marls similar to those presently accumulating in the Everglades represent the freshwater environment predating marine transgression into the bay (Davies and Cohen 1989). Overlying these freshwater peats are marine carbonate sediments; intercalated silt and clay sized carbonate particles layered with shelly debris horizons. These marine sediments form a network of subtidal mudbanks and mangrove islands that partition the bay into more than 30 small basins, serving to restrict water mixing, and attenuating both tidal amplitude and current. To the west, Florida Bay gradually merges with the Gulf of Mexico; to the east and south the bay is bounded by the Florida Keys, which restrict exchange with the Atlantic Ocean to narrow channels between the islands.

\subsubsection{Sample Collection}

Sediment cores were collected from four banks in Florida Bay representing the transition from the mangrove ecotone in NE Florida Bay (Trout Creek) through the banks of the middle bay (Russell Key and Bob Allen Bank), out to the western boundary of the bay 
(Ninemile Bank) in the summer of 2002 (Figure 4.1; Table 4.1). Piston coring was completed using a pontoon boat mounted tripod, acrylic core barrels (14 $\mathrm{cm}$ diameter), a PVC piston with two o-rings and an eyebolt for steel cable attachment to the tripod, and iron handles for gripping the core barrel. The core barrels were pressed down into the soft sediment using the barrel mounted handles, while the piston remained stationary at the sediment surface. Cores were pressed to bedrock where possible and then retrieved by lifting with the handles as the piston stayed fixed in place within the barrel to maintain vacuum. Core bottoms were capped before piston removal and intact cores were transported to the Key Largo Multi-Agency Science Center, Everglades National Park, where they were sectioned into 2-cm intervals. Samples of wet sediment (6cc) were taken from each 2-cm increment for geochemical and stable isotopic analyses which were refrigerated until drying in the laboratory at $70^{\circ} \mathrm{C}$. Samples were then powdered and homogenized using a ceramic mortar and pestle.

\subsubsection{Geochemical Analyses}

Sediment bulk density, \% total inorganic carbon (TIC), and \% total organic carbon (TOC) were analyzed using standard drying/weight loss upon ignition methods. Sediment organic $\mathrm{C}$ and $\mathrm{N}$ content were analyzed using a $\mathrm{CHN}$ analyzer (Fisons NA1500, Florida International University Seagrass Ecosystems Laboratory), and P content was determined by a dry-oxidation, acid hydrolysis extraction followed by colorimetric analysis of phosphate concentration of the extract (Fourqurean et al. 1992b). Bulk sediment organic matter $\delta^{13} \mathrm{C}$ and $\delta^{15} \mathrm{~N}$ were analyzed using a Thermo Scientific Delta $\mathrm{C}$ continuous flow mass spectrometer coupled to a Carlo Erba elemental analyzer 


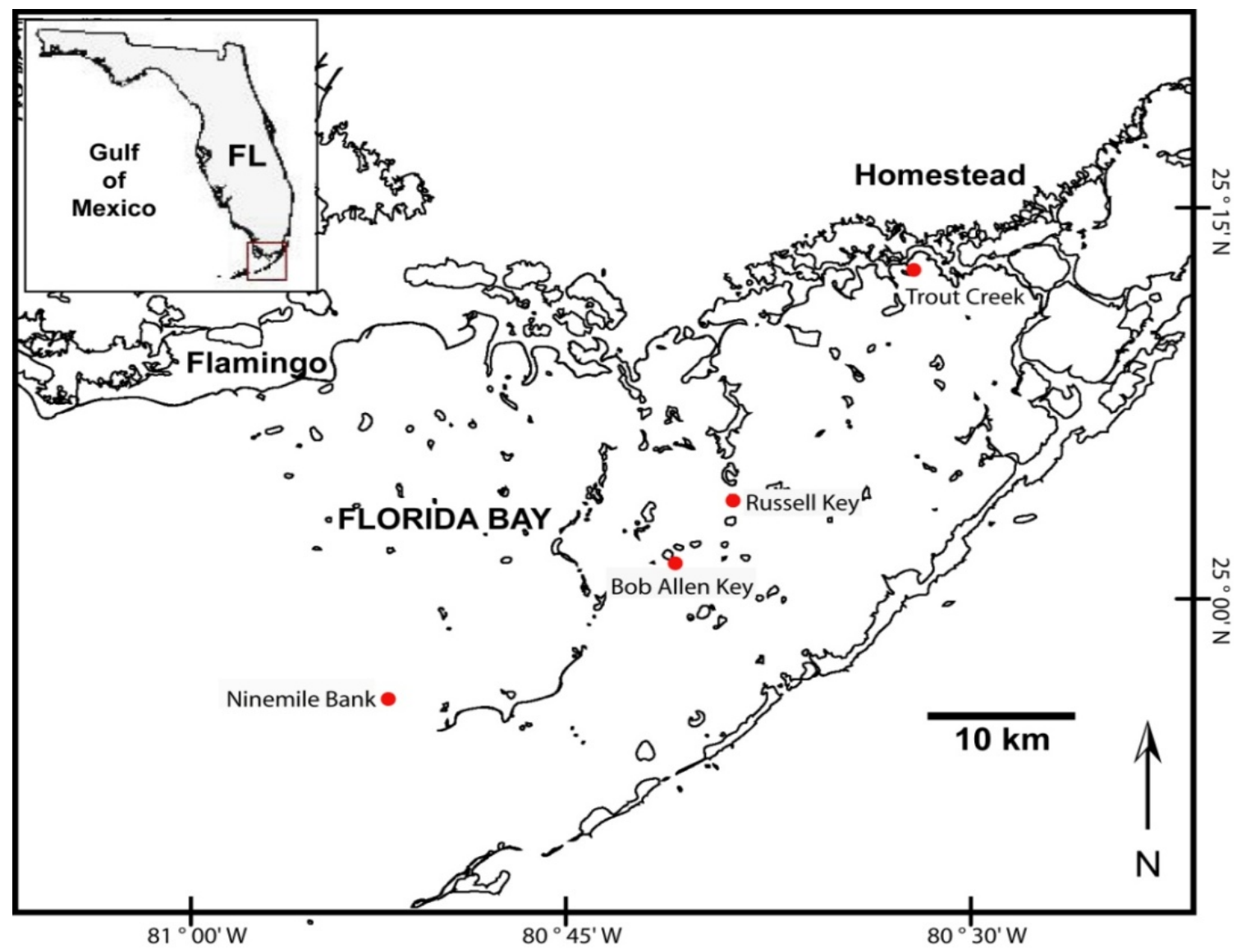

Figure 4.1 Map of Florida Bay, showing core collection sites at Ninemile Bank, Bob Allen Key, Russell Bank, and Trout Creek.

Table 4.1 Florida Bay core locations, calculated average sedimentation rate, core length recovered, and depth with age contraints by ${ }^{210} \mathrm{~Pb}$ chronology.

\begin{tabular}{|c|c|c|c|c|c|}
\hline \multirow[b]{2}{*}{ Site } & \multicolumn{2}{|c|}{ Location } & \multirow{2}{*}{$\begin{array}{l}\text { Sedimentation Rate } \\
\mathrm{cm} / \mathrm{yr}\end{array}$} & \multirow{2}{*}{$\begin{array}{l}\text { Core length } \\
\quad(\mathrm{cm})\end{array}$} & \multirow{2}{*}{$\begin{array}{c}\text { Depth of } \\
{ }^{210} \mathrm{~Pb} \\
\text { chronology } \\
(\mathrm{cm})\end{array}$} \\
\hline & $\mathrm{N}$ & W & & & \\
\hline Trout Creek & $25^{\circ} 12.632^{\prime}$ & $80^{\circ} 31.955^{\prime}$ & 0.6 & 96 & 92 \\
\hline Russell Bank & $25^{\circ} 03.871^{\prime}$ & $80^{\circ} 37.501^{\prime}$ & 1.1 & 166 & 166 \\
\hline Bob Allen Bank & $25^{\circ} 01.731^{\prime}$ & $80^{\circ} 40.795^{\prime}$ & 0.4 & 194 & 66 \\
\hline Ninemile Bank & $24^{\circ} 57.186^{\prime}$ & $80^{\circ} 53.545^{\prime}$ & 0.5 & 222 & 98 \\
\hline
\end{tabular}

(EA-IRMS). The EA was used to combust sediment organic material and to reduce the formed gases to $\mathrm{N}_{2}$ and $\mathrm{CO}_{2}$, which were then measured for isotopic ratio in a continuous flow mode. Samples were analyzed for $\delta^{13} \mathrm{C}$ and $\delta^{15} \mathrm{~N}$ before and after acidification to 
remove carbonates; $\delta^{15} \mathrm{~N}$ was measured on unaltered powdered sediment, $\delta^{13} \mathrm{C}$ was measured on powdered subsamples after acidification with liquid $1 \mathrm{~N} \mathrm{HCl}$. Approximately $100 \mathrm{mg}$ of powdered sample were acidified with $20 \mathrm{ml} \mathrm{HCl}$. After 12 hours, acid was decanted and then replaced, and this process was repeated until there was no further effervescence apparent. Samples were then rinsed to neutral $\mathrm{pH}$ with deionized water, dried, and analyzed for $\delta^{13} \mathrm{C}$. All values are reported using standard delta $(\delta)$ notation relative the international standards of atmospheric $\mathrm{N}\left(\mathrm{AIR}, \mathrm{N}_{2}\right)$ and Vienna Pee Dee Belemnite (V-PDB) for C:

$$
\delta=\left[\left(R_{\text {sample }} / R_{\text {standard }}\right)-1\right] \times 1000
$$

Where $R$ is the isotopic ratio, i.e. ${ }^{15} \mathrm{~N} /{ }^{14} \mathrm{~N}$ or ${ }^{13} \mathrm{C} /{ }^{12} \mathrm{C}$ in either sample or standard. Analytical reproducibility of the reported $\delta$ values, based on sample replicates (analyzed every tenth sample) and internal lab standards (also inserted after every block of 10 samples), was better than $\pm 0.2 \%$ or for $\delta^{15} \mathrm{~N}$ and $\pm 0.08 \%$ for $\delta^{13} \mathrm{C}$.

\subsubsection{Age Dating of Sediment Cores}

Duplicate cores from each of the sampling sites were dated using ${ }^{210} \mathrm{~Pb}$ activity by USGS St. Petersburg, FL using methods described by Holmes et al. (2001) with modifications described by $\mathrm{Xu}$ et al. (2007). Samples were dried at $60^{\circ} \mathrm{C}$ for 48 hours to determine water content and were then ground with mortar and pestle to a fine powder. Five gram subsamples of material were taken for alpha ${ }^{210} \mathrm{~Pb}$ analyses. The ${ }^{210} \mathrm{~Pb}$ activity was calculated by measuring the alpha activity of the granddaughter isotope, ${ }^{210} \mathrm{Po}$, assuming secular equilibrium between the two. A leaching process was used followed by autoplating onto silver planchets for alpha counting according to the procedures of Flynn 
(1968). Overall counting uncertainties were $\pm 5 \%$, determined by triplicate analyses of a subset of samples (Xu et al. 2007). Calculation of sedimentation rates at each site from ${ }^{210} \mathrm{~Pb}$ data used the constant rate of supply (CRS) model, which assumes that the flux of

${ }^{210} \mathrm{~Pb}$ is constant through time without regard for variability in sediment flux (Holmes et al. 2001, Xu et al. 2007), see Table 4.1. Individual sedimentation rates were generated by applying a best-fit curve to the count data using an unweighted Marquardt-Levenberg parameter optimization method (Press et al. 1989). The advantage of this procedure is that all data points, including negative values resulting from counting errors, are utilized in the calculation of sediment accumulation rate (Holmes et al. 2001). Further, this method corrects for the propagation of 'old age' error, inherent in other best-fit interpolations (Holmes et al. 2001). The estimated age resolution for the core chronologies presented here was \pm 2 years (Xu et al. 2007). Independent measurements of background ${ }^{226} \mathrm{Ra}$ from sediments in accreting banks in a previous study demonstrated coherent, decreasing linear relationship with depth (r-squared values of 0.6-0.9; Holmes et al. 2001). Subtracting background radium values from ${ }^{210} \mathrm{~Pb}$ totals in the 2001 study demonstrated that Florida Bay sediments are in adequate disequilibrium for calculating accurate geochronology (Holmes et al. 2001).

\subsubsection{Statistical Analyses}

Data were analyzed using a variety of parametric and non-parametric methods. Due to problems with normality and equal variance among cores data sets, the KruskalWallis One-Way Analysis of Variance on Ranks was used to compare geochemical parameters between the four core locations and Dunn's test was used for post hoc pair- 
wise comparisons. Student's t-tests were used to compare paired data sets (i.e. Pre- and post-1910 datasets of each parameter at each specific site) of normally distributed variables, whereas the Mann Whitney Rank Sum Test was used where parametric tests were not appropriate.

\subsection{RESULTS}

The down-core variations of sedimentary organic $\delta^{15} \mathrm{~N}$ and $\delta^{13} \mathrm{C}$ values for all four cores, together with bulk density, and carbon, nitrogen, and phosphorus elemental ratios, are presented in Figures 4.2-5. In terms of sediment characteristics, all four cores are composed of fine grained carbonate mud interspersed with winnowed shelly debris layers and all cores contained scattered seagrass fragments. X-ray analyses demonstrated no evidence of significant bioturbation or disruption of layering, however the ${ }^{210} \mathrm{~Pb}$ chronology in the Bob Allen Bank core showed that the surface sediments at this site date to 1987 , suggesting that sediment re-suspension and transport are factors influencing unsheltered mud banks in the central bay. The remaining cores were collected from the accreting leeward bank sides relative to prevailing current directions and show no evidence of scouring.

\begin{tabular}{ccc} 
Table 4.2 $\delta^{13} \mathrm{C}(\%), \delta^{15} \mathrm{~N}(\%)$ & $($ Mean $\pm \mathrm{SD})$ \\
\hline Site & Mean $\delta^{13} \mathrm{C}(\% \mathrm{)})$ & Mean $\delta^{15} \mathrm{~N}(\% \mathrm{)})$ \\
\hline Trout Creek & $-19.64 \pm 0.62$ & $5.65 \pm 0.59$ \\
Russell Bank & $-11.34 \pm 0.65$ & $5.24 \pm 0.33$ \\
Bob Allen Bank & $-9.96 \pm 0.50$ & $4.16 \pm 0.42$ \\
Ninemile Bank & $-11.61 \pm 0.72$ & $2.22 \pm 0.43$ \\
\hline
\end{tabular}




\subsubsection{Trout Creek Sediment Geochemistry}

The Trout Creek core represents the northeastern end member of the Florida Bay transect, recovered near the mangrove fringe at the mouth of Trout Creek. This area is influenced by one of four creeks draining Taylor Slough in the Southeastern Everglades. This core has the most depleted carbon isotopic signatures (Figure 4.2), ranging between -21.42 and $-18.42 \%$ with an average value of $-19.64 \pm 0.62 \%$ (Table 4.2 ). Conversely, the $\delta^{15} \mathrm{~N}$ values of the OM in the Trout Creek core were the most enriched of all the cores

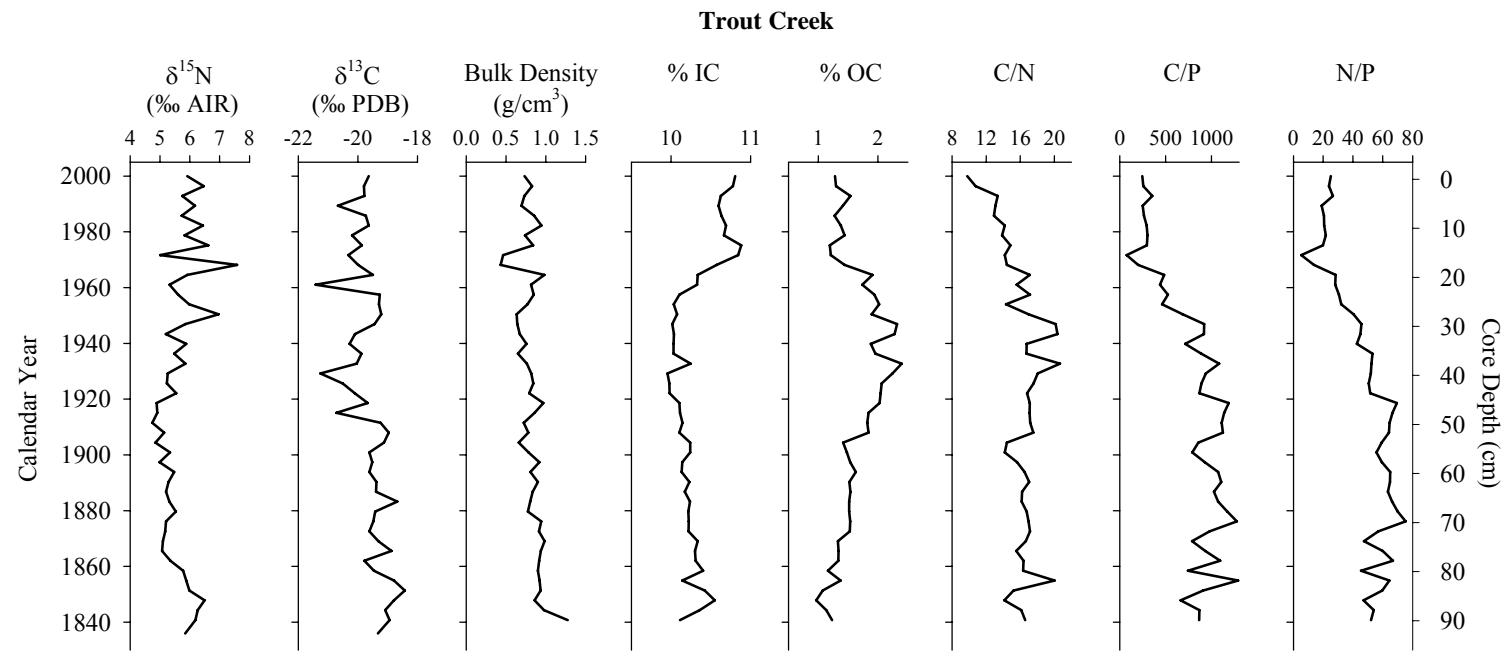

Figure 4.2 Geochemical dataset from the upper $92 \mathrm{~cm}$ of a core collected from the mouth of Trout Creek, Northeastern Florida Bay. Carbon and nitrogen stable isotopic data, bulk density, inorganic and organic carbon weight percent, and molar atomic ratios are shown

analyzed, ranging from +4.74 to $+7.58 \%$ with an average value of $+5.65 \pm 0.59 \%$.

In the lower portion of the core, 1838-1910, all geochemical parameters remain fairly constant, showing no first order trends. Post-1910, however, there was a marked increase in variability, particularly in the carbon and nitrogen isotopic values. Where $\delta^{13} \mathrm{C}$ had shown very little change over time in the lower portion of the core, the upper section is characterized by several negative carbon excursions of up to $2 \%$ and a slight depletion trend is evident over time. Nitrogen isotopic values after 1910 show a first 
order enrichment trend of $1.7 \%$ with wide fluctuations of up to $2.5 \%$. Similar pre- and post-1910 trends are also evident in elemental ratios of preserved sedimentary organic matter. Before 1910, molar $\mathrm{C} / \mathrm{N}, \mathrm{C} / \mathrm{P}$, and N/P ratios were all relatively stable, averaging $16.3 \pm 1.3,980 \pm 170$, and $60.1 \pm 7.8$ respectively. Post 1910 all three parameters show marked declines overtime. $\mathrm{C} / \mathrm{N}$ decreases to 9.7 while $\mathrm{C} / \mathrm{P}$ decreases from $>1000$ to just 245 and N/P decreases from 65 to 25.

\subsubsection{Russell Bank Sediment Geochemistry}

The Russell Bank core (Figure 4.3) demonstrated more enriched $\delta^{13} \mathrm{C}$ values than Trout Creek, ranging from -12.71 to $-10.50 \%$ with an average value of $-11.34 \pm 0.56 \%$ (Table 4.2). Nitrogen isotopic values were not significantly different from those in Trout Creek sediments, with an average value of $+5.24 \pm 0.33 \%$ and ranging between +4.38 and $+5.93 \%$.

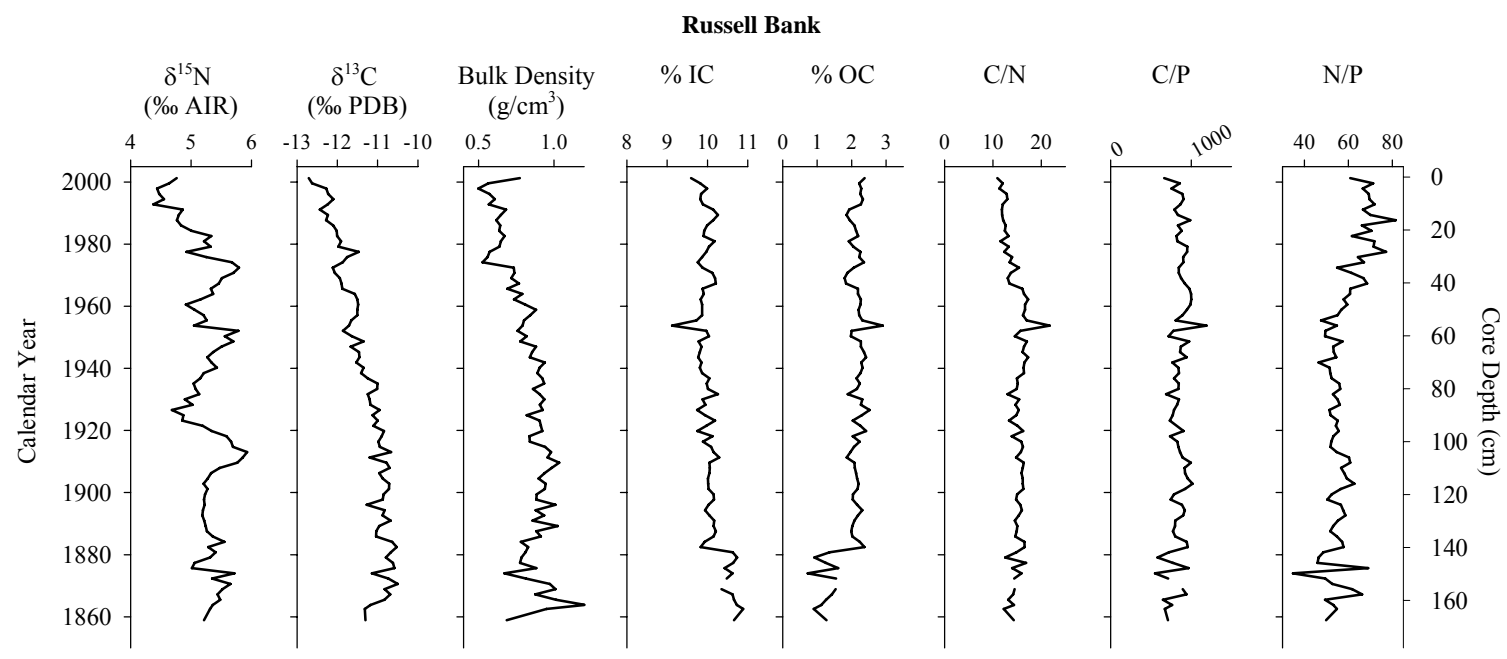

Figure 4.3 Geochemical dataset from a $166 \mathrm{~cm}$ long core collected at Russell Bank, Central Florida Bay. Carbon and nitrogen isotopic data, bulk density, inorganic and organic carbon weight percent, and molar atomic ratios are shown.

As observed in the Trout Creek core, carbon and nitrogen isotopic signatures were 
consistent in the lower portion of the core. Since 1910 , however, $\delta^{13} \mathrm{C}$ became more depleted steadily from $-10.8 \%$ to $-12.8 \%$, while $\delta^{15} \mathrm{~N}$ transitioned to a period of high variability, exhibiting a first order depletion trend affecting a 1\%o change with several superimposed second order oscillations. Between 1910 and $1928, \delta^{15} \mathrm{~N}$ values decreased from +5.93 to $+4.68 \%$, then grew more enriched until $1952(+5.78 \%$ ). A second depletion cycle reached a minimum in $1960(+4.92 \%$ o before increasing to $+4.79 \%$ in 1972. From 1972 to $2002 \delta^{15} \mathrm{~N}$ signatures decreased to an overall minimum of $+4.44 \%$. This final 30 year depletion trend is coincident with a significant increase in molar N/P ratios. This change is largely driven by increasing sediment $\% \mathrm{~N}$ (Figure 4.6 ). $\mathrm{C} / \mathrm{N}$ ratios exhibit a slight decreasing trend at this time, but both $\mathrm{C} / \mathrm{N}$ and $\mathrm{C} / \mathrm{P}$ remain relatively constant over the full length of the core chronology with means of $14.72 \pm 1.64$ and 845 \pm 98 , respectively.

\subsubsection{Bob Allen Bank Sediment Geochemistry}

The historical profile of nutrient and isotopic parameters in the Bob Allen Bank (Figure 4.4) sediment column shows trends similar to those observed at Russell Bank, as would be expected of two closely spaced locations in similar mid-bay environments. However, the Bob Allen sediment record has far lower variability, particularly in the organic matter isotopic record, which may be attributable to scouring and reworking of the surface sediments over time, serving to mix sediment packages, averaging out variations. Lower sedimentation rates at Bob Allen Bank, in conjuction with the two centimeter sampling resolution utilized for analyses may also contribute to dampening of potential variability in the sedimentary record by averaging longer time slices in each 
individual sample, removing higher frequency variations. As in both Trout Creek and Russell Bank sediment chronology, the lower portion of the Bob Allen Bank core exhibits relative stability in both isotopic and elemental composition, whereas post-1910 sediments record pronounced first order trends and increases in variability. The $\delta^{13} \mathrm{C}$ values show the same 2\%o up-core depletion trend between 1910 and the present as shown at Russell Bank, however Bob Allen Bank sediments are 1-1.5\% enriched in ${ }^{13} \mathrm{C}$ relative to Russell Bank over the entire sediment history.

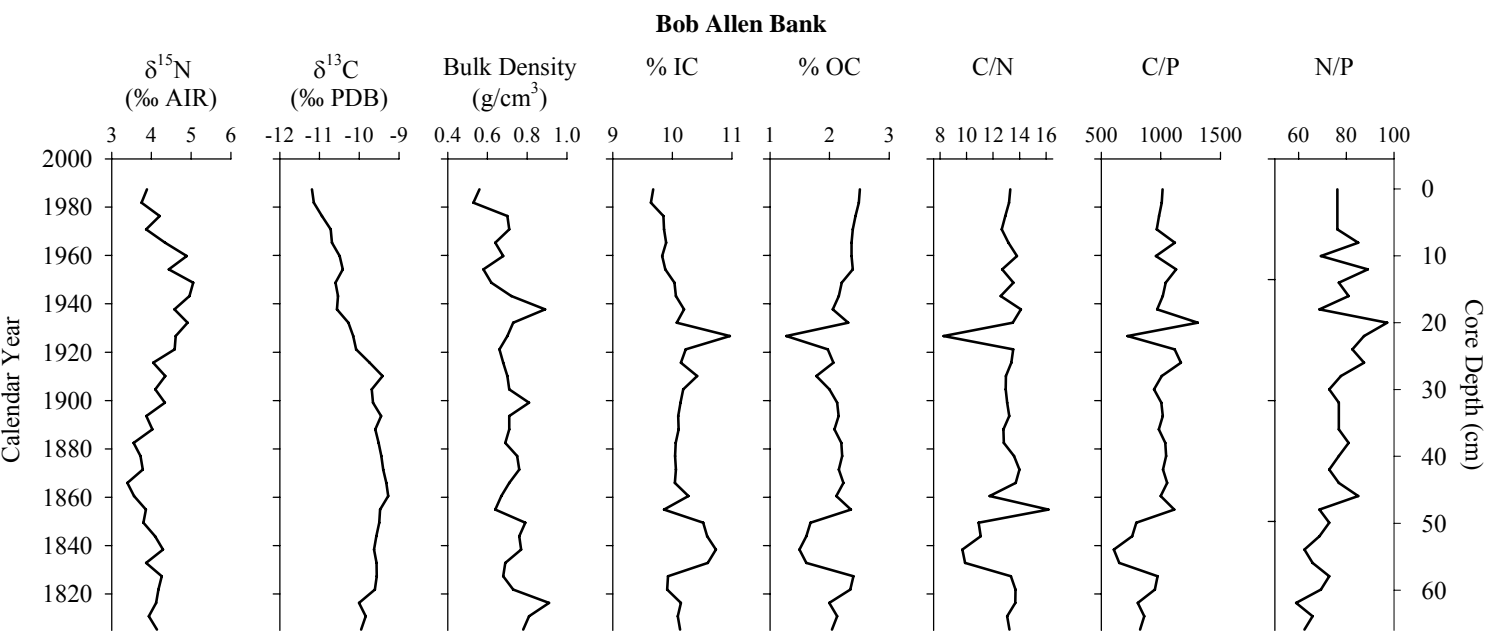

Figure 4.4 Geochemical dataset from the upper $66 \mathrm{~cm}$ of a core collected from Bob Allen Bank, Central Florida Bay. Carbon and nitrogen isotopic data, bulk density, inorganic and organic carbon weight percent, and molar atomic ratios are shown.

Values range between -11.19 and $-9.27 \%$ with an average value of $-9.97 \pm 0.56 \%$. The nitrogen isotopic record exhibits similar second order oscillations over time as in Russell Bank post-1910 sediments, however no first order trend is evident, and on the whole, Bob Allen Bank $\delta^{15} \mathrm{~N}$ values are more depleted, ranging from $+3.39-+5.05 \%$ with a mean value of $+4.16 \pm 0.42 \%$. Although N/P ratios exhibit increased variability in the upper portion of the core, elemental ratios are consistent with Russell Bank trends also, exhibiting fairly stable values over the entire chronology. 


\subsubsection{Ninemile Bank Sediment Geochemistry}

The Ninemile Bank core (Figure 4.5) represents the western boundary end member of the Florida Bay coring transect, and has been influenced by its proximity to the Gulf of Mexico (GOM) over time. GOM inputs are most obvious in phosphorus content, which has historically been up to three times the concentrations observed in sediments from other areas in Florida Bay (Figure 4.6). Higher P-levels significantly alter C/P and N/P ratios, which were much lower at Ninemile Bank than at the other coring locations,

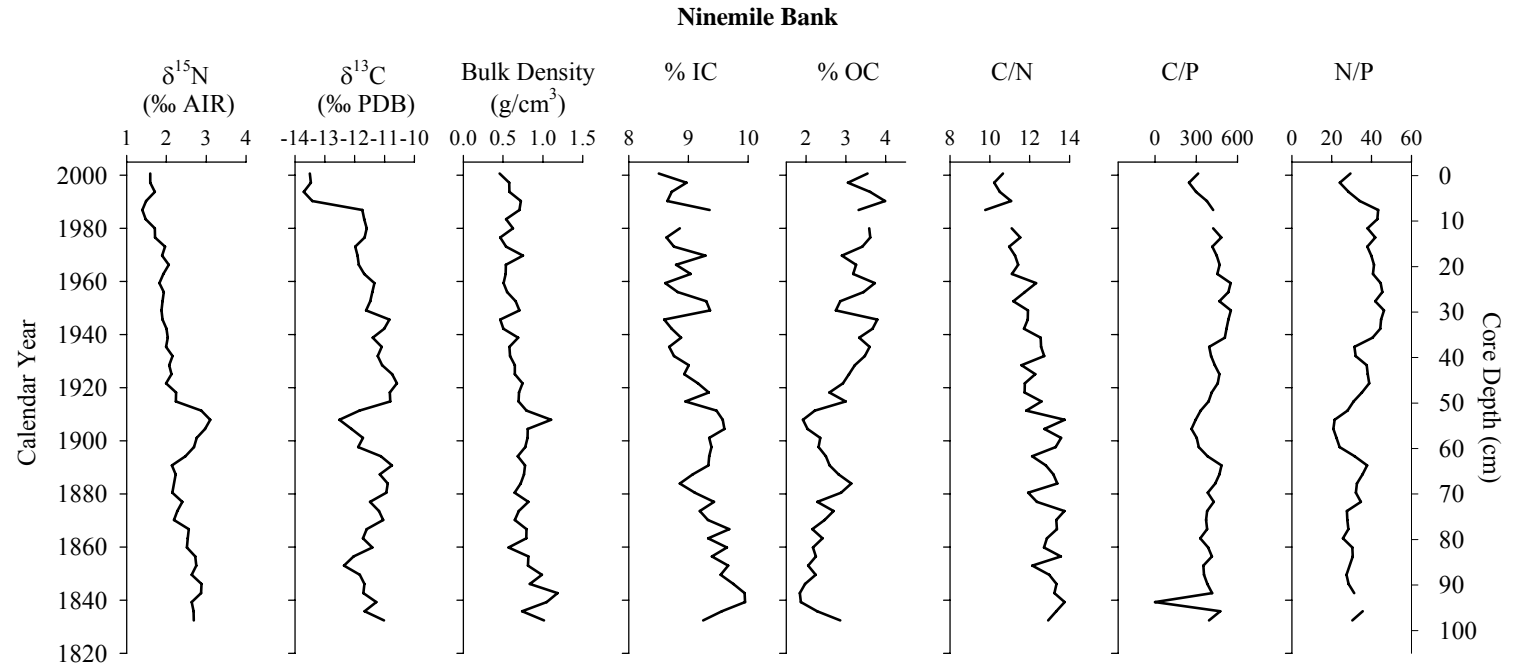

Figure 4.5 Geochemical dataset from the upper $66 \mathrm{~cm}$ of a core collected from Ninemile Bank, Western Florida Bay. Carbon and nitrogen isotopic data, bulk density, inorganic and organic carbon weight percent, and molar atomic ratios are shown.

averaging $410.39 \pm 73.99$ and $34.0 \pm 6.9$ respectively. Nitrogen isotopic compositions are also significantly different from those preserved in the other cores, exhibiting much more depleted values. The most enriched $\delta^{15} \mathrm{~N}$ value, $+3.10 \%$, representing a significant enrichment event coincident with the 1910 inflection point evident bay-wide, is still depleted relative to the lowest $\delta^{15} \mathrm{~N}$ value found elsewhere (Bob Allen Bank; +3.39\%o). At Ninemile Bank, sedimentary $\delta^{15} \mathrm{~N}$ values show a progressive depletion trend throughout the 150 years illustrated here. In contrast to the nitrogen isotope record, $\delta^{13} \mathrm{C}$ 
values are relatively constant in the lower portion of the core, varying between -11 and $12 \%$. More depleted values $\left(-12.5 \%\right.$ ) correspond to the positive $\delta^{15} \mathrm{~N}$ excursion at the turn of the century and are immediately followed by a $2 \%$ enrichment to $-10.5 \%$ near 1920. Between 1920 and 1980, carbon values show a gradual first order depletion trend of $1 \%$. A second $-2 \% \delta^{13} \mathrm{C}$ excursion is evident in the most recent 10 years of sedimentary history, with recent values between -13.4 and $-13.7 \%$. Neither C/P nor N/P ratios change significantly up-core, although both ratios decrease synchronously with the 1910 isotopic excursion. C/P values fall from 480 to 295 while N/P ratios decrease from 37 to 20 , before recovering to average values, $410.39 \pm 73.99$ and $34.0 \pm 6.91$, respectively. $\mathrm{C} / \mathrm{N}$ ratios, however, display a progressive depletion trend after 1910 , coincident with increasing $\%$ organic carbon content. In fact, the Ninemile Bank sediments post-1910 have organic carbon concentrations $1 \%$ higher than all other sediments sampled, increasing to $3.5 \%$ in the upper core, whereas sediments from the other sites vary between 1.0 and $2.5 \%$. Decreasing $\mathrm{C} / \mathrm{N}$ ratios while organic carbon content increases demonstrates that nitrogen concentrations have increased at a higher rate than organic carbon burial.

\subsubsection{Organic carbon, total nitrogen, and total phosphorus content}

Synchronous changes over time in sediment nutrient concentrations may mask variability in nutrient delivery to the Florida Bay ecosystem in the sediment record when only elemental ratios are considered. Concentrations of organic carbon (OC), total nitrogen (TN), and total phosphorus (TP) (all expressed as \% dry weight; these data are presented in terms of mass accumulation rate in appendices 3-7) from all coring sites are shown in 
Figure 4.6. Concentrations of OC (Figure 4.6a) ranged from less than $1 \%$ to greater than $4 \%$. The overall highest concentrations of OC were observed in the Ninemile Bank core, while the lowest OC burial occurred in Trout Creek sediments. Russell Bank and Bob Allen Bank sediments exhibited intermediary OC content of similar magnitude. In fact, while Ninemile Bank and Trout Creek average OC abundances were significantly different from both each other and the paired mid-bay sites, Bob Allen Bank and Russell Bank showed no significant difference in concentration (Table 4.3). In terms of variability over time, the inflection point noted in isotopic values and in most elemental ratios at 1910 (Figures 4.2-5) is clearly reflected in organic carbon delivery and and preservation. Ninemile Bank displayed a 2\% increase in organic carbon content, and an apparent increase in variability at that time. An additional inflection point can be seen in 1947, most clearly defined in the Ninemile Bank and Trout Creek sediment records (Figure 4.6). Trout Creek sediments reflect a $1 \%$ increase in organic carbon between 1910 and 1940 and then a decrease over the remainder of the sediment chronology. Bob Allen Bank and Russell Bank also display the 1910 shift, however increases in both cores are on the order of only $0.5 \%$.

Total nitrogen concentrations in the sediment records also showed significant variation between coring sites (Table 4.3 ), ranging from $0.05 \%$ to greater than $0.4 \%$, but general trends broadly parallel those seen in OC. Ninemile Bank exhibited the highest $\mathrm{TN}$ content, and concentrations followed a similar pattern to that of OC, with a large positive shift and greater variability evident in post 1910 sediments. Russell Bank and Bob Allen Bank had both lower TN concentrations and lower variability than Ninemile 
Bank, but also show a change in trend at 1910. Nitrogen content was lowest in Trout Creek sediments and showed an increasing trend over the full core chronology.

The extreme phosphorus limitation so often documented (Fourqurean et al. 1992, 1993, Boyer et al. 1999, Rudnick et al. 1999) for NE Florida Bay is reflected in sediment total phosphorus concentrations throughout the last 150 years of sedimentation. TP concentrations vary in the mid-bay and NE ecotone sites (Bob Allen Bank, Russell Bank, and Trout Creek) between $0.003 \%$ and $0.040 \%$, approaching detection limits for analyses. Sediments at Ninemile Bank clearly reflect Gulf of Mexico inputs, with up to

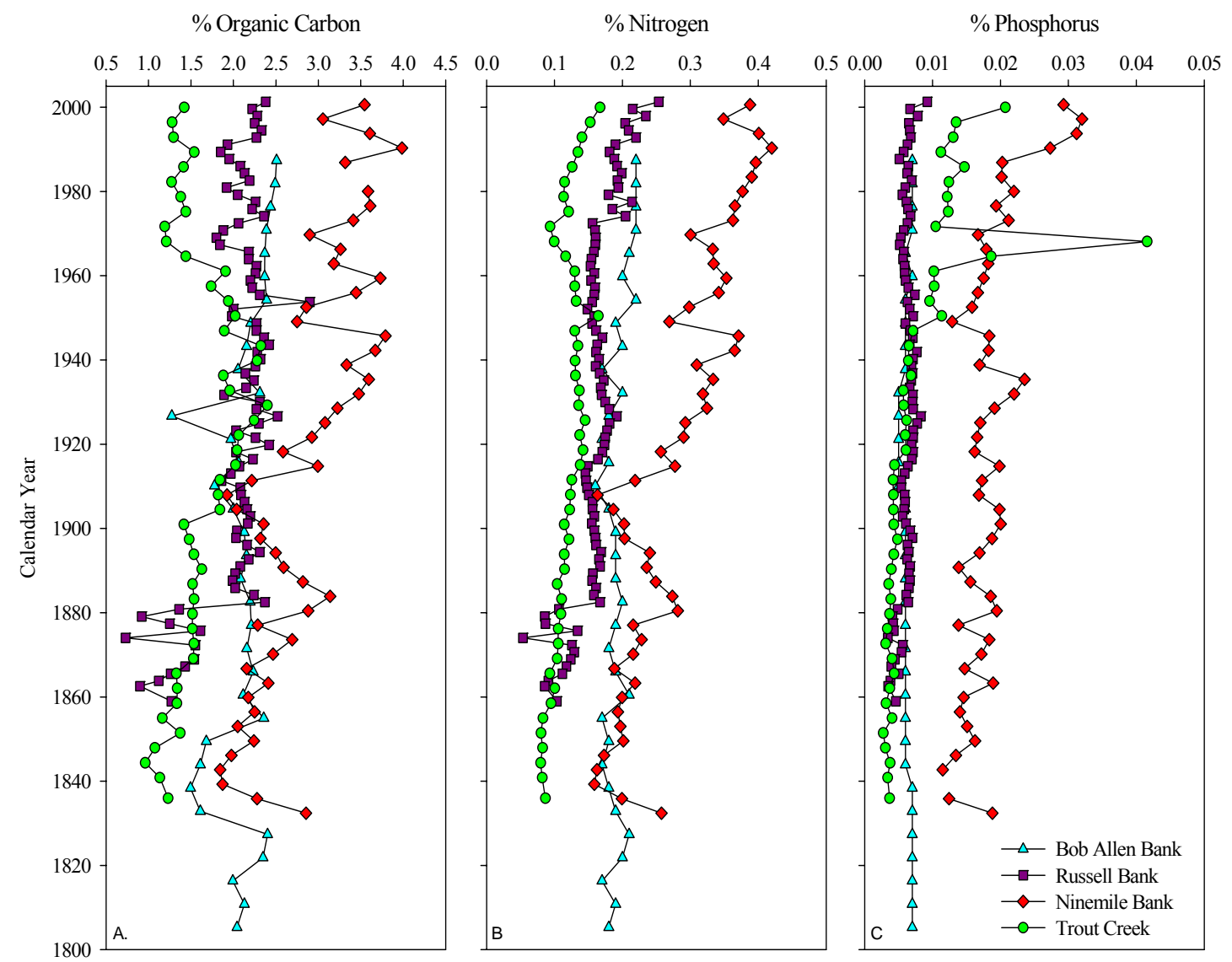

Figure 4.6 Sediment elemental composition data over time at four sites in Florida Bay expressed in weight \%. A) Organic carbon B) Nitrogen C) Phosphorus. 
Table 4.3 Percent elemental compositions and calculated molar ratios for each core (Mean \pm SD).

\begin{tabular}{ccccccc}
\hline Site & $\%$ OC & $\% \mathrm{~N}$ & $\% \mathrm{P}$ & Molar C:N & Molar C:P & Molar N:P \\
\hline Trout Creek & $1.60 \pm 0.36$ & $0.12 \pm 0.02$ & $0.008 \pm 0.007$ & $15.89 \pm 2.4$ & $755.57 \pm 345.4$ & $46.04 \pm 18.5$ \\
Russell Bank & $2.06 \pm 0.45$ & $0.16 \pm 0.03$ & $0.006 \pm 0.001$ & $14.72 \pm 1.6$ & $845.80 \pm 98.2$ & $57.95 \pm 8.0$ \\
Bob Allen Bank & $2.11 \pm 0.30$ & $0.19 \pm 0.02$ & $0.006 \pm 0.0007$ & $12.83 \pm 1.4$ & $969.89 \pm 146.8$ & $75.66 \pm 8.3$ \\
Ninemile Bank & $2.84 \pm 0.60$ & $0.28 \pm 0.08$ & $0.018 \pm 0.004$ & $12.26 \pm 1.0$ & $410.39 \pm 74.0$ & $34.04 \pm 6.9$ \\
\hline
\end{tabular}

three times higher $\%$ TP. In terms of temporal trends, both Trout Creek and Ninemile Bank sedimentary TP displayed a distinct increasing trend after 1947, resulting in doubled TP concentrations in both cores.

\subsubsection{Carbon and nitrogen isotopic signatures}

Significant spatial variability was evident in both $\mathrm{C}$ and $\mathrm{N}$ isotopic data (Figure 4.7). Trout Creek sedimentary $\delta^{13} \mathrm{C}$ data very clearly distinguished the mangrove ecotone from open water Florida Bay banks, with more depleted values relative to all other cores (Table 4.2). Bob Allen Bank sediments exhibited the most enriched $\delta^{13} \mathrm{C}$ signatures, with Russell Bank and Ninemile Bank approximately 1\%o enriched. In terms of $\delta^{13} \mathrm{C}$, both Trout Creek and Bob Allen Bank were significantly different from Ninemile and Russell Banks, however, the latter two sites show no statistical difference in $\delta^{13} \mathrm{C}$ values. Ninemile Bank was the most isotopically distinct site in terms of $\delta^{15} \mathrm{~N}$, with significantly depleted values (Table 4.2). Bob Allen Bank preserved more enriched $\delta^{15} \mathrm{~N}$ values at an average of 4.16\%. Trout Creek and Russell Bank were both significantly enriched relative to both Bob Allen Bank and Ninemile Bank, however there was no significant difference between the two.

The distinct pattern inflection at 1910 evident in sediment nutrient content is also shown by the sediment organic matter isotopic values (Figure 4.7; open symbols indicate 


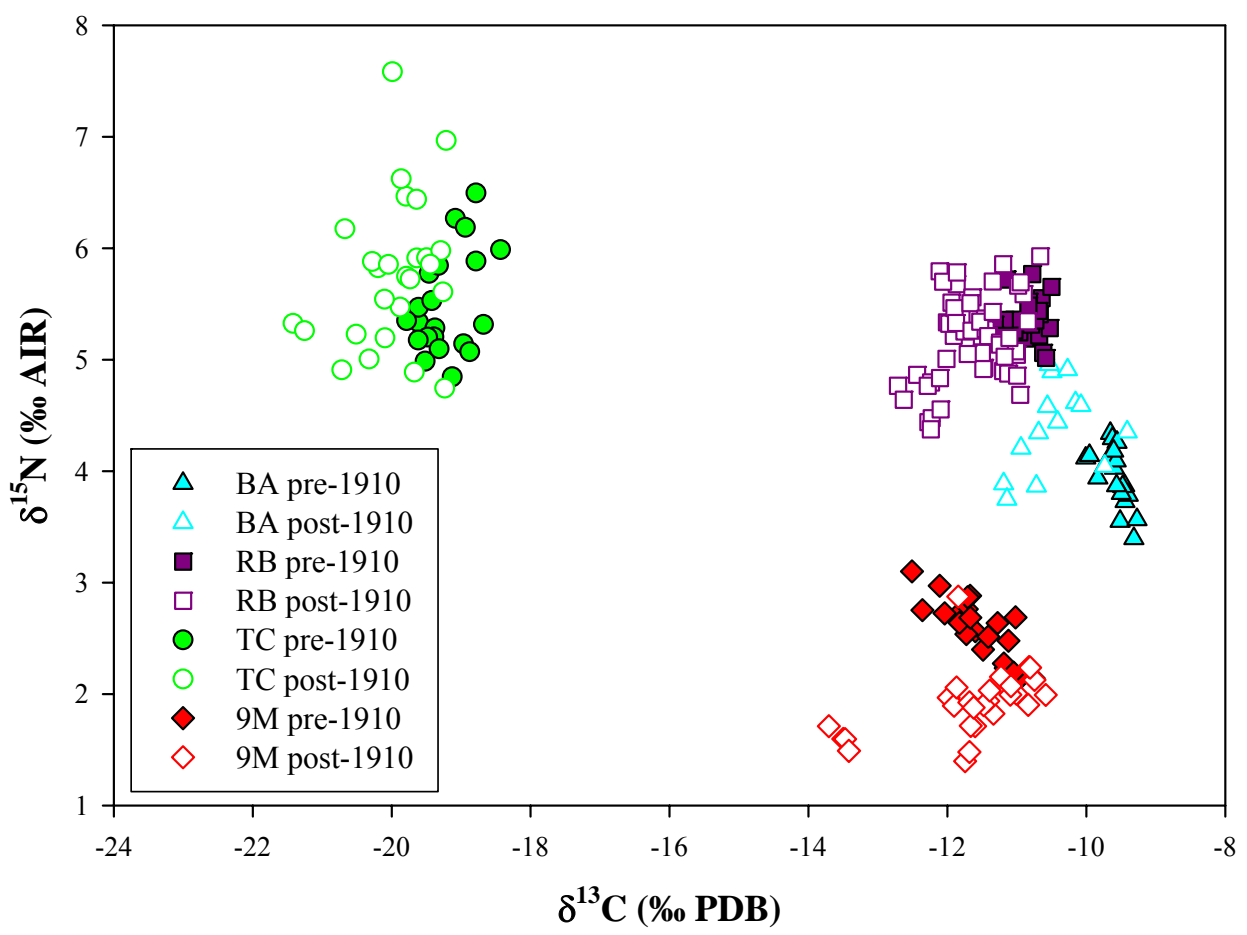

Figure 4.7 Carbon and nitrogen isotopic data from four Florida Bay cores: Bob Allen Bank (BA), Russell Bank (RB), Trout Creek (TC), and Ninemile Bank (9M). Closed symbols denote data from core stratigraphy between 1850 and 1910; open symbols denote data from 1910 to 2002.

Table 4.4 Sediment geochemical parameter means \pm st. dev. comparing pre- and post- 1910 data sets

\begin{tabular}{|c|c|c|c|c|c|c|c|}
\hline Core & Interval & $\begin{array}{c}\delta^{13} \mathrm{C} \\
(\% \mathrm{~V}-\mathrm{PDB}) \\
\end{array}$ & $\begin{array}{c}\delta^{15} \mathrm{~N} \\
(\% \mathrm{AIR}) \\
\end{array}$ & $\mathrm{C}: \mathrm{N}$ & $\mathrm{N}: \mathrm{P}$ & $\mathrm{C}: \mathrm{P}$ & $\mathrm{n}$ \\
\hline \multirow[t]{3}{*}{$\mathrm{TC}$} & pre-1910 & $-19.22 \pm 0.37$ & $+5.50 \pm 0.46$ & $16.33 \pm 1.29$ & $60.07 \pm 7.76$ & $984.17 \pm 171.30$ & 21 \\
\hline & post-1910 & $-19.98 \pm 0.58$ & $+5.77 \pm 0.67$ & $15.53 \pm 2.92$ & $34.71 \pm 16.77$ & $570.94 \pm 341.6$ & 26 \\
\hline & p-value & $<0.001$ & 0.113 & 0.556 & $<0.001$ & $<0.001$ & \\
\hline \multirow[t]{3}{*}{$\mathrm{RB}$} & pre-1910 & $-10.85 \pm 0.22$ & $+5.34 \pm 0.18$ & $15.10 \pm 1.19$ & $54.78 \pm 6.75$ & $827.74 \pm 125.70$ & 30 \\
\hline & post-1910 & $-11.62 \pm 0.49$ & $+5.19 \pm 0.38$ & $14.52 \pm 1.82$ & $59.68 \pm 8.21$ & $855.67 \pm 78.95$ & 54 \\
\hline & p-value & $<0.001$ & 0.055 & 0.295 & 0.007 & 0.491 & \\
\hline \multirow[t]{3}{*}{ BA } & pre-1910 & $-9.58 \pm 0.19$ & $+3.94 \pm 0.27$ & $12.77 \pm 1.54$ & $71.822 \pm 6.77$ & $918.03 \pm 141.90$ & 19 \\
\hline & post-1910 & $-10.46 \pm 0.48$ & $+4.43 \pm 0.42$ & $12.90 \pm 1.35$ & $80.513 \pm 7.66$ & $1035.6 \pm 129.00$ & 15 \\
\hline & p-value & $<0.001$ & $<0.001$ & 0.84 & 0.001 & 0.018 & \\
\hline \multirow[t]{3}{*}{$9 \mathrm{M}$} & pre-1910 & $-11.53 \pm 0.47$ & $+2.56 \pm 0.28$ & $13.07 \pm 0.11$ & $29.31 \pm 4.57$ & $381.33 \pm 57.28$ & 23 \\
\hline & post-1910 & $-11.69 \pm 0.87$ & $+1.91 \pm 0.30$ & $11.54 \pm 0.76$ & $37.82 \pm 6.12$ & $434.98 \pm 78.50$ & 27 \\
\hline & p-value & 0.653 & $<0.001$ & $<0.001$ & $<0.001$ & 0.011 & \\
\hline
\end{tabular}


sediment data post- 1910; Table 4.4). Carbon isotope values at mid-bay and mangrove ecotone sites (Bob Allen Bank, Russell Bank, and Trout Creek) all show a significant negative carbon isotopic shift in post 1910 sedimentary records. Greater variability in $\delta^{13} \mathrm{C}$ values was also evident at these sites after 1910. Mean $\delta^{15} \mathrm{~N}$ values showed no change between pre- and post-1910 datasets at Trout Creek and Russell Bank; however, variability in the data did increase after 1910 at both sites. At both Bob Allen and Ninemile Banks, statistically significant shifts in $\delta^{15} \mathrm{~N}$ values were apparent in pre- versus post-1910 sediments. At Bob Allen Bank, N-isotopic values grew more enriched, while at Ninemile Bank isotopic composition became progressively more depleted after $1910 . \delta^{13} \mathrm{C}$ values was also evident at these sites after 1910 . Mean $\delta^{15} \mathrm{~N}$ values showed no change between pre- and post-1910 datasets at Trout Creek and Russell Bank; however, variability in the data did increase after 1910 at both sites. At both Bob Allen and Ninemile Banks, statistically significant shifts in $\delta^{15} \mathrm{~N}$ values were apparent in pre- versus post-1910 sediments. At Bob Allen Bank, N-isotopic values grew more enriched, while at Ninemile Bank isotopic composition became progressively more depleted after 1910.

\subsection{DISCUSSION}

\subsubsection{Isotopic and elemental source characterization}

Tracing carbon flow in an estuarine ecosystem by stable $\mathrm{C}$ isotope techniques is possible because of large differences between the $\delta^{13} \mathrm{C}$ values of terrestrial and marine primary producers. In the case of Florida Bay, these differences are among mangrove, seagrass, and both macro- and microalgal inputs. Atmospheric $\mathrm{CO}_{2}$, the carbon source 
for plants, has a $\delta^{13} \mathrm{C}$ value of approximately $-8.0 \%$ (Francey and Allison 1996), yet terrestrial plants utilizing the Calvin Cycle (C3 photosynthetic pathway) as a carbon fixation mechanism have an average $\delta^{13} \mathrm{C}$ of $-27 \%$. This fractionation results from isotopic selectivity of RUBISCO (ribulose-1,5-biphosphate carboxylase) preferentially utilizing ${ }^{12}$ C. Carbon fixation in aquatic plants such as seagrasses, however, may be significantly influenced by diffusive boundary limitations which decrease isotopic discrimination and cause much smaller isotopic depletions relative to environmental $\mathrm{CO}_{2}$ isotopic compositions (Andrews and Abel 1981, Benedict et al. 1980). Nitrogen isotopic values in estuarine organic matter reflect more complex dynamics, influenced by the interplay of nutrient source variations both in isotopic value and $\mathrm{N}$-species (nitrate versus ammonium), by chemical fractionation related to remineralization, $\mathrm{N}$-fixation, and denitrification processes operating on source pools, and by fractionations associated with nutrient uptake and incorporation into biomass.

Representative isotopic compositions and sparse molar $\mathrm{C}: \mathrm{N}$ data for various potential organic matter sources to Florida Bay sediments are given in Table 4.4. The strong disparity between terrestrial and aquatic plant materials in terms of carbon isotopic composition is readily apparent, with seagrasses and mangrove organics representing enriched versus depleted signatures, while aquatic macroalgae and particulate organic matter fall as intermediates. The three open water Florida Bay cores (Russell Bank, Bob Allen Bank, and Ninemile Bank) all display carbon isotopic signatures characteristic of seagrass organic material through the entire sediment record (Figure 4.7; Kieckbusch et al. 2004, Fourqurean et al. 2005, Behringer and Butler 2006). Bulk sediment C:N ratios in these three cores however vary between 10 and 14, representing lower values than 
Table 4.5 Representative isotopic and elemental compositions of terrestrial verses marine organic matter sources to Florida Bay.

\begin{tabular}{|c|c|c|c|c|c|}
\hline & Genera & $\delta^{15} \mathrm{~N}(\%)$ & $\delta^{13} \mathrm{C}(\%)$ & Molar C:N & reference \\
\hline \multicolumn{6}{|l|}{ Terrestrial } \\
\hline Floc & & $2.4 \pm 1.1$ & $-29.0 \pm 9.1$ & 11.3 & Williams and Trexler 2006 \\
\hline \multirow[t]{2}{*}{ Periphyton } & & $2.6 \pm 1.0$ & $-28.3 \pm 2.1$ & 13.6 & Williams and Trexler 2006 \\
\hline & & 3.2 to 4.7 & -28 to -22 & & Wozniak et al. 2008 \\
\hline Sawgrass & Cladium & 1.0 to 2.7 & -25 to -22 & & Wozniak et al. 2008 \\
\hline \multirow[t]{6}{*}{ Mangrove } & Rhizophora & $0.1 \pm 1.0$ & $-26.2 \pm 0.59$ & & Kieckbusch et al. 2004 \\
\hline & Rhizophora & $5.5 \pm 0.5$ & $-28.7 \pm 1.4$ & 100 & Fourqurean and Schrlau 2003 \\
\hline & Rhizophora & & $-26.7 \pm 0.3$ & & Lin et al. 1990 \\
\hline & Rhizophora & & -26 to -30 & & Fleming et al. 1990 \\
\hline & Rhizophora & 8.0 & -27 & & Zieman et al. 1984 \\
\hline & Rhizophora & 6.0 & -27 & & Zieman et al. 1984 \\
\hline \multicolumn{6}{|l|}{ Marine } \\
\hline \multirow[t]{3}{*}{$\mathrm{POM}^{*}$} & & 0.5 to 4.0 & -14 to -20 & & Mumford 1999 \\
\hline & & & -18.0 & & Behringer and Butler 2006 \\
\hline & & $4.9 \pm 0.23$ & $-18.4 \pm 0.06$ & & Kieckbusch et al. 2004 \\
\hline \multirow[t]{7}{*}{ Macroalgae } & Penicillus & $1.7 \pm 1.9$ & $-18.3 \pm 0.39$ & & Kieckbusch et al. 2004 \\
\hline & Caulerpa & $2.3 \pm 0.82$ & $-15.8 \pm 3.57$ & & Kieckbusch et al. 2004 \\
\hline & Halimeda & $1.0 \pm 0.76$ & $-18.9 \pm 3.23$ & & Kieckbusch et al. 2004 \\
\hline & Laurencia & 1.4 & -13.8 & & Kieckbusch et al. 2004 \\
\hline & Laurencia & $2.3 \pm 0.1$ & $-16.2 \pm 3.4$ & & Behringer and Butler 2006 \\
\hline & mixed ave. & & -13 & & Zieman et al. 1984 \\
\hline & mixed ave. & & -22 & & Zieman et al. 1984 \\
\hline \multirow[t]{7}{*}{ Seagrass } & Thalassia & $1.4 \pm 0.24$ & $-11.5 \pm 2.81$ & & Keieckbusch et al. 2004 \\
\hline & Thalassia & $6.0 \pm 0.3$ & $-10.7 \pm 0.2$ & 17 & Fourqurean and Schrlau 2003 \\
\hline & Thalassia & $2.8 \pm 0.6$ & $-6.5 \pm 0.7$ & & Behringer and Butler 2006 \\
\hline & Thalassia & -5 to +9 & -15 to -7 & 22.6 & Fourqurean et al. 2005 \\
\hline & Syringodium & 0.7 & -10.7 & & Kieckbusch et al. 2004 \\
\hline & Syringodium & 2.0 & -8 to -4 & 18 to 22 & Fourqurean unpub. data \\
\hline & Halodule & -2 to +4 & -15 to -9 & 18 to 22 & Fourqurean unpub. data \\
\hline \multirow[t]{4}{*}{ Epiphytes } & & $4.1 \pm 0.8$ & $-12.3 \pm 1.6$ & & Behringer and Butler 2006 \\
\hline & & $2.6 \pm 0.16$ & $-16.7 \pm 0.52$ & & Kieckbusch et al. 2004 \\
\hline & & $2.7-8.3$ & & & Mumford et al. 1999 \\
\hline & & & -24 & & Zieman et al. 1984 \\
\hline
\end{tabular}

* Particulate Organic Matter

those measured in modern Florida Bay seagrass tissues (20-25; Fourqurean et al. 1992a, b, Fourqurean et al. 2005). Preferential mineralization of $\mathrm{N}$ relative to $\mathrm{C}$ during early 
diagenesis has been documented in a number of sedimentary environments (Herczeg et al. 2001, Meyers 1997) resulting in increasing C: $\mathrm{N}$ as diagenesis proceeds. The apparent overall secular decrease in the $\mathrm{C}: \mathrm{N}$ ratio of Florida Bay sedimentary organic matter is thus not attributable to organic degradation of seagrass material. One possible mechanism involves bacterial utilization of external nitrogen source inputs, which serves to increase $\mathrm{N}$ content of bulk sedimentary organics as bacterially-mediated carbon remineralization occurs, resulting in decreasing C:N (Rice and Hanson 1984, Lamb et al. 2006, Lamb et al. 2007). Alternatively, preservation of an organic mixture including planktonic, epiphytic, or benthic microalgae could contribute a component with much lower C:N (Redfield C:N for planktonic algae varies from 4-6; bacterial C:N is generally $<10$; Redfield 1934, Meyers 1994, Tyson 1995).

Particulate organic matter C-isotopic compositions measured Bay-wide vary between -20 and -15\% (Mumford 1999, Evans et al. 2006). In many cases more labile organic components are isotopically enriched, so that degredation results in isotopic depletion of residual material (Macko et al. 1993, DeLang et al. 1994, Prahl et al. 1997, Ogrinc et al. 2005); however, isotopic enrichment with degradation of highly labile particulate material has also been documented (Valiela et al. 1985, Guo et al. 2004). Such processes could lead to $\delta^{13} \mathrm{C}$ values considered characteristic of seagrasses in organic material of algal origin. The $\delta^{13} \mathrm{C}$ of bulk sedimentary organic material at open bay core locations reflects both seagrass and microalgal inputs over the last 150 years. $\mathrm{Xu}$ et al. (2007) demonstrated similar results in organic biomarker records from the open bay core locations. Seagrasses and microalgal biomarkers dominated in Russell Bank, Bob Allen Bank, and Ninemile Bank cores, showing changes similar to those in the 
isotope values in the frequency and magnitude of concentration oscillations after the turn of the century (Xu et a. 2007). The depleted $\delta^{13} \mathrm{C}$ values of Trout Creek sediments suggest a stronger influence of terrigenous organic matter (Lin et al. 1991); which is also in agreement with organic biomarker evidence of mangrove OM inputs to the sediments at Trout Creek. Xu et al. (2006) showed $7000 \mathrm{ng} / \mathrm{g}$ sediment of the mangrove biomarker, taraxerol, in surficial sediments from Trout Creek while there was less than $300 \mathrm{ng} / \mathrm{g}$ sediment in western Florida Bay. This dominance of mangrove organic biomarkers was also observed through the entirety of the Trout Creek core, corroborating the isotopic evidence of terrigenous organic material (Xu et al. 2007). Mangrove material was expected to be the main OM source in Trout Creek sediments, because of the close proximity of Taylor Slough freshwater discharge and the southern Everglades mangrove ecotonal fringe. Mixing between marine and terrestrial organic matter inputs is necessary to explain $\delta^{13} \mathrm{C}$ values falling between those typical of mangroves (-26\%) and local seagrasses (-12 to $-7 \%$ ). Again however, like the open Florida Bay core sites, C:N values at Trout Creek have been much lower over the entire sediment history than those expected of either seagrass $(>20)$ or mangrove (generally $>50$; Ruttenberg and Goni 1997, Yamamuro 2000)) organic material. Although Xu et al. $(2006,2007)$ found significant concentrations of taraxerol, and much lower concentrations of algal markers, $\mathrm{C}: \mathrm{N}$ values as low as 8 imply that there is either a significant algal input of organic matter or a significant bacterial component and high level of carbon remineralization altering C:N ratios preserved in the sediment at Trout Creek. In a similarly distributed core study, Orem et al. (1999) found fine fraction sediment organic C:N ratios in the same range found here, which they attributed to the greater $\mathrm{N}$ content of organic matter derived from 
algae rather than either terrestrial plants or seagrasses.

Interpretation of nitrogen isotopic values is more complex than carbon due to the web of geochemical $\mathrm{N}$-cycling processes and different isotopic fractionations among those processes, competing fractionation associated with species-specific uptake, and differences in diagenetic alteration of various organic nitrogenous substrates. Many studies invoke the nitrogen isotopic composition of sedimentary organic matter as a direct record of surface water nutrient utilization and paleoproductivity, explaining organic matter $\delta^{15} \mathrm{~N}$ values as a product of Rayleigh fractionation kinetics (Calvert et al. 1992, Francois et al. 1992, Altabet and Francois 1994, Minoura et al. 1997). Yet, nutrient utilization and paleoproductivity have not successfully explained the sedimentary record in lake sediments (Teranes and Bernasconi 2000), perhaps because phosphorus, rather than nitrogen, is the primary limiting nutrient in lacustrine settings. When only a small portion of ambient nitrogen is consumed, the nitrogen isotopic composition of the dissolved inorganic nitrogen pool is never significantly altered.

Relative nutrient limitations in Florida Bay are primary factors in understanding the nitrogen isotope record preserved at various locations in the Bay. Analogous to many lacustrine settings, and like many shallow carbonate environments, it is commonly held that South Florida coastal waters are generally phosphorus limited (Lapointe 1987, Lapoine and O'Connell 1989, Short et al. 1990, Fourquerean et al. 1992a, b, Fourqurean et al. 1993, Frankovich and Fourqurean 1997, Brand 2002). Calcium carbonate chemically scavenges phosphate from seawater (DeKanel and Morse 1978), thus phosphorus concentrations in Florida Bay, particularly in the northeastern zone, are commonly very low, often approaching the limits of analytical detection (Boyer et al. 
1997). However, there is a significant gradient from east to west in phosphorus availability, as Gulf of Mexico inputs, in addition to abundant phosphorite deposits along the west coast of Florida, serve as a source of much higher phosphorus concentrations in the western boundary zone (Boyer et al. 1997, 1999, Brand 2002). An opposing gradient exists in available nitrogen, with high dissolved inorganic $\mathrm{N}$ availability in the northeast decreasing to limiting levels in the west (Boyer et al. 1997, Brand 2002). Most of the $\mathrm{N}$ is delivered in freshwater discharge from the Everglades-agricultural system via Taylor Slough and the South-Dade Water Conveyance System canals. While phosphorus may also be present in the upland zone of the agricultural drainage, carbonate geochemical scavenging and efficient vegetation P-assimilation result in downstream discharge of nitrogen-rich, phosphorus-poor runoff (Brand 2002). Thus in the nitrogen replete, phosphorus limited zone of NE Florida Bay, organic nitrogen isotopic values are likely to reflect nutrient sources, whereas in the N-limited W Florida Bay, $\delta^{15} \mathrm{~N}$ values are more likely to reflect not only initial source isotopic composition, but may be complicated by nutrient utilization and microbial recycling of nutrient pools. Interestingly however, the Trout Creek core, collected from the high-nitrogen NE Florida Bay zone, exhibits the most variable and enriched sediment organic $\delta^{15} \mathrm{~N}$ compositions of all the cores (Figure 4.7). These enriched values (up to $+8 \%$ ) may reflect the influence of denitrification in the anoxic sediments of the adjacent mangrove ecotone leading to inputs of nitrogen with more enriched isotopic compositions in residual nutrients, or upstream use of organic waste fertilizer in the Everglades agricultural zone resulting in enriched nutrient sources discharging through Taylor Slough. The two most positive N-isotopic excursions, representing over $2 \%$ fluctuations, are coincident with peak \% phosphorus 
concentrations preserved in the sediments. Large enrichments over mean $\delta^{15} \mathrm{~N}$ may be the expression of nutrient utilization and residual enrichment during bloom events triggered by pulses of high phosphorus availability in the zone of severe P-limitation.

The remaining three core locations, distributed along the east to west gradient in $\mathrm{N}$-availability, show a progressive down-gradient depletion in terms of nitrogen isotopic composition, with the most depleted signals in the western bay zone (exhibiting the lowest ambient $\mathrm{N}$ concentrations in the modern environment). The transition evident in mean sedimentary organic matter isotopic composition is consistent with the modern distribution of $\delta^{15} \mathrm{~N}$ values measured in leaves from the dominant seagrass of the region, Thalassia testudinum. Fourqurean et al. (2005) showed a similar spatial pattern, with more enriched $\delta^{15} \mathrm{~N}$ values in NE Florida Bay and adjacent to the mangrove ecotone, transitioning to lower values along the E-W axis of Florida Bay. It would seem then that the nitrogen isotopic values preserved in the sediment organic material also reflect the dominance of seagrass inputs. More depleted $\delta^{15} \mathrm{~N}$ values in the western zone may be tied to the prevalence of cyanobacteria associated with Shark River discharge and along much of the SW coastline (Brand 2002). Drifter trajectories show significant transport paths moving Shark River flow and SW coastal nutrient sources along the western boundary of Florida Bay, passing through Florida Keys channels around Long Key (Lee et al. 2002). These flow-paths cross directly over the Ninemile Bank core collection site, and it can be assumed that this has been the case through recent history. Further, Evans et al. (2006) showed depleted $\delta^{15} \mathrm{~N}$ values coincident with a bloom of such cyanobacteria, indicating $\mathrm{N}$-fixation as a possible nitrogen source in the $\mathrm{N}$-limited zone. Higher inputs of either cyanobacterial organic material, or seagrass material grown with recycled $\mathrm{N}$ 
initially fixed by cyanobacteria, could account for the lower nitrogen isotopic values and increases in $\% \mathrm{~N}$ content preserved throughout the section of Ninemile Bank sediment history presented here.

\subsubsection{Anthropogenic influences on Florida Bay over time}

The most significant geochemical changes evident in the last 150 years of sediment history recorded in the cores presented here are the concurrent shifts in the complete suite of geochemical parameters evident just after the turn of the century. Prior to 1910 nearly all parameters exhibited relatively constant values with no obvious first order trends. Following 1910, however, bay-wide sedimentary records of elemental and isotopic compositions transition to a phase of increased variability, and long term trends

develop over the remainder of the century. This shift, present regardless of sedimentation rate and organic material sources, is too coincidental to reflect a diagenetic pattern downcore. Carbon isotopic compositions of all open-bay cores (Russell Bank, Bob Allen Bank, and Ninemile Bank) all show a trend of progressive depletion trend after 1910 (Figures 4.3-5). While this isotopic trend could reflect gradual changes in organic matter source, favouring more isotopically depleted marine algal inputs, this hypothesis is not supported by organic biomarker indicators of algal input measured on the same cores $(\mathrm{Xu}$ et al. 2007). Seagrass biomarkers showed dramatic increases in abundance over this time period in all cores, whereas algal biomarkers increased significantly only after 1980 in all cores except Russell Bank, where algal markers were abundant between 1880 and 1970 (Xu et al. 2007). Gradual depletion in $\delta^{13} \mathrm{C}$ of dissolved inorganic carbon (DIC), reconstructed based on both mollusk shell (Halley and Roulier 1999) and coral skeleton 
(Swart et al. 1996) carbon isotopic values, follows an abrupt shift at between 1905 and 1912. The change just after the turn of the century was attributed to the construction of Flagler's Railroad along the Florida Keys and concurrent infilling of several Keys channels (Swart et al. 1996, Brewster Wingard et al. 2001). Filling the passes decreased circulation and exchange with the Atlantic Ocean, serving to increase the residence time of water masses in Florida Bay basins, and allowing more of the isotopically depleted oxidative decomposition products to be retained within the water column (Swart et al. 1996, Halley and Roulier 1999). Not only was this isotopically depleted inorganic carbon incorporated into carbonates over time, but also in organic material subsequently preserved in the sediments.

Similar changes have been documented in many studies, whose results are further confirmed here. Foraminiferal and molluscan assemblage data from cores collected at Bob Allen Bank and Russell Bank show long term increases in salinity, switching to a highly fluctuating salinity regime after 1900 (Brewster-Wingard and Ishman 1999). These faunal indicators seem to vary on a 20 -year cycle as recorded at Russell Bank, whereas Bob Allen Bank showed only a few fluctuations of longer duration. Similar patterns are shown by the nitrogen isotopic compositions of the Bob Allen Bank and Russell Bank cores presented here. It may be that the lower sedimentation rate and higher propensity for scouring and resuspension of sediments at Bob Allen Bank dampens the record of second order oscillations. However it may also be a factor that Russell Bank is located in a more interior, isolated basin of Florida Bay, while Porpoise Lake, of which Bob Allen Bank is a northern boundary, is connected to Lignumvitae Basin to the SW and Cotton Key Basin to the SE, both of which have some level of 
connectivity directly to the Atlantic Ocean, thus may benefit from higher levels of flushing and exchange then would a more isolated interior basin. In more isolated basins of the bay, climatic fluctuations controlling evaporation and freshwater flow would likely have generated higher variability in water column parameters.

While there is a strong argument for the importance of the hydrologic circulation changes precipitated by railroad construction in the early 1900's supported by the pervasive shift in all geochemical parameters measured, first order depletion trends of 1.5 to $2 \%$ seen in all the sediment organic matter $\delta^{13} \mathrm{C}$ records presented here are consistent with depletion trends in coral and sclerosponge skeleton $\delta^{13} \mathrm{C}$ records (Figure 4.8) (Swart et al. 1996, Swart et al. 2002).

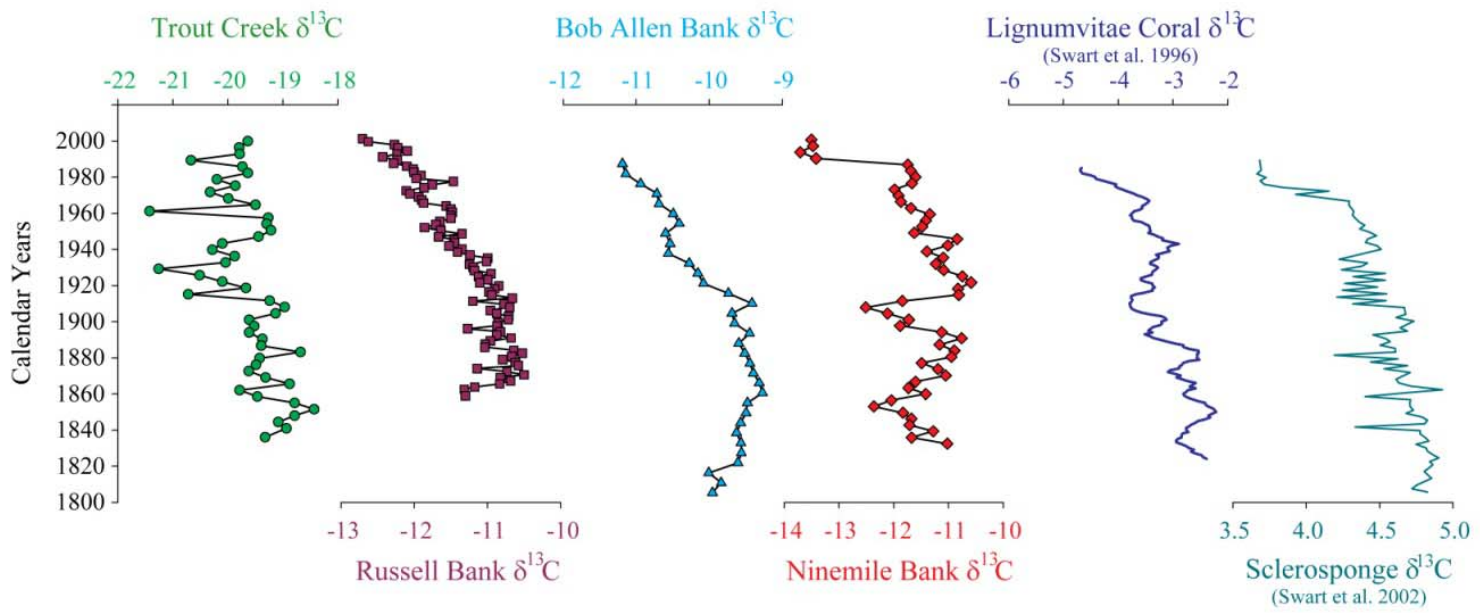

Figure 4.8 Carbon isotopic data from all Florida Bay cores plotted with two ${ }^{13} \mathrm{C}$ datasets from Swart et al., a coral record (Swart et al. 1996) and a sclerosponge record (Swart et al. 2002). A gradual 1.52\%o depletion can be seen in all these regional records which is consistent with the Suess Effect.

The long-term depletion in OM and skeletal records reflect the progressive depletion in atmospheric $\delta^{13} \mathrm{C}$ resulting from the burning of fossil fuels since industrialization, a change conventionally known as the Suess Effect (Revelle and Suess 1957, Cialis et al. 1995, Swart et al. 1996, Swart et al. 2002, Francey et al. 2002, Anderson et al. 2005).In 
addition to the major shift in geochemical trends coincident with altered circulation patterns and the advent of the Suess Effect atmospheric changes, a depletion trend is evident in $\delta^{15} \mathrm{~N}$ after 1945 at the interior Florida Bay sites, Bob Allen Bank and Russell Bank. Also, a shift toward increasing variability in isotopic values is apparent after 1935 in the Trout Creek record, coincident with trends toward lower values in all elemental ratios $(\mathrm{C}: \mathrm{N}, \mathrm{N}: \mathrm{P}$, and $\mathrm{C}: \mathrm{P})$. The timing of these changes reflects the onset of large scale water management altering freshwater delivery to Florida Bay from the Everglades.

By 1930, the backbone of major canals diverting freshwater east to the Atlantic rather than south through the Everglades to Florida Bay was in place, and Tamiami Trail construction, bisecting the Everglades, leaving only culvert flow connecting the northern and southern parts of the drainage basin, was complete (Light and Dineen 1994). Later, drainage of the Everglades was greatly accelerated after 1947 with the development of the South and Central Florida Flood Control Project, an initiative which lowered the water table and reduced the flow of freshwater to Florida Bay, increasing its overall salinity and shifting Florida bay from a brackish to often hyper-saline ecosystem (Light and Dineen 1994, Smith et al. 1989, McIvor et al. 1994, Brand 2002). These profound changes in freshwater delivery to the Florida Bay system are clearly evident in the Trout Creek core, collected near the outflow of Taylor Slough (Figure 4.2). Here, significant decreases in elemental ratios suggest lower allocthonous mangrove inputs, resulting in less terrestrial organic carbon preservation. While there is an increase in variability of concentrations of organic biomarkers indicative of mangrove inputs during this time interval, it coincides with overall trends of increasing concentration in the Trout Creek core (Xu et al. 2007). Lower organic carbon storage may result from decreasing 
freshwater flow, nutrient flux, and autochthonous productivity. Alternatively, decreasing organic carbon contents may be the result of increased organic decomposition related to longer residence times as a consequence of lower freshwater flushing.

The impact of changes in water management in the Everglades has been demonstrated in a number of proxy studies in the past. Both the studies of coral fluorescence by Smith et al. (1989) and in mollusk shells by Brewster-Wingard et al. (1999) showed an amplification of the frequency and magnitude of salinity fluctuations after 1940, attributable to changes in water management practices following completion of the South Florida Canal System that served to reduce and disrupt the natural freshwater flow into Florida Bay. Further, ostracod (Cronin et al. 2001) and diatom (Huvane and Cooper 2001) assemblages also exhibit synchronous and marked shifts at this time. These studies postulate increases in benthic seagrass community dominance after 1950; it seems reasonable then, that decreases in freshwater delivery and ensuing increases in Florida Bay salinity actually drove the proliferation of marine seagrass benthic communities. Restoration of historic flow patterns may therefore degrade these marine communities.

\subsubsection{Hurricane history}

In addition to the pronounced geochemical traces left by changes in anthropogenic influence over the Everglades watershed and Florida Bay in the $20^{\text {th }}$ century, naturally occurring climatic catastrophes have also left geochemical fingerprints recorded in the sedimentary history of Florida Bay. Several major hurricanes have impacted South Florida during the past century. Most notable on the list include the un- 
named September hurricane of 1919 (Category 4 on the Saffir-Simpson Scale), the Labor Day Hurricane of 1935 (Category 5), Hurricane Donna of 1960 (Category 4), and Hurricane Andrew in 1992 (Category 5). Major tropical cyclones cause immediate and longer term environmental changes in the coastal zone due to sediment erosion and deposition, and storm induced bidirectional sediment transport (Tabb and Jones 1962, Wanless et al. 1994). Such sediment disturbance has been identified in cores from several banks in Florida Bay, demonstrated by discontinuities in ${ }^{210} \mathrm{~Pb}$ records coincident with storms in 1935, 1948, 1960, and1992 (Kang and Treyfry 2003, Alvarez-Zarikian et al. 2001).

In addition to sedimentation pulse disturbances, heavy precipitation associated with storm events has also historically been evident in excessive freshwater discharge through the Everglades sloughs (Kang and Treyfry 2003, Donders et al. 2008). These pulses almost certainly carry high levels of mangrove detritus to the adjacent estuarine system, particularly if the storm event is associated with high windfield impacts resulting in defoliation of coastal mangrove forests (Wanless et al. 1994). In a sediment core study from Rookery Bay, one of the estuaries of the SW Florida Shark River Slough drainage, Donders et al. (2008) found a direct correlation between the major South Florida hurricane events and mangrove pollen minima, coincident with disturbance-indicative maxima in ragweed pollen. These results were interpreted to imply high levels of mangrove mortality in storm events, thus precluding pollen production in year(s) following the storms, and invasion of ragweed and low level shrubs in disturbed canopy gap areas (Donders et al. 2008). Indeed, impact analysis studies of Hurricanes Donna (1960) and Andrew (1992) show that the main impact on the natural communities 


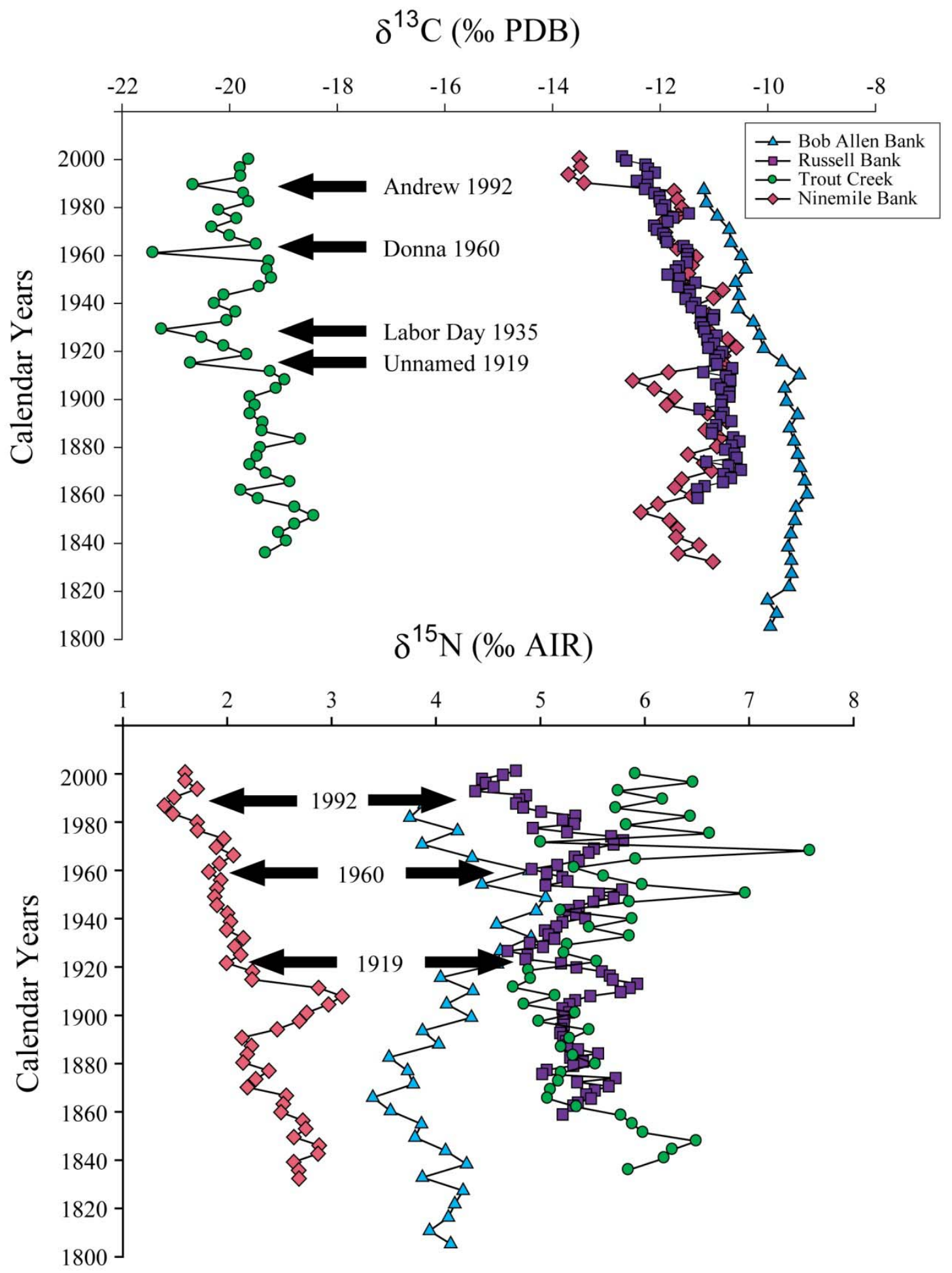

Figure 4.9 Carbon and nitrogen isotope stratigraphy from the four Florida Bay cores highlighting isotopic evidence of hurricane disturbance. 
occurred as destruction of interior wetland, rather than coastal erosion (Tabb and Jones 1962, Wanless et al. 1994, Doyle et al. 1995). Both these storm events caused some coastal erosion along Florida's Southern mangrove coastline, however the predominant impact was widespread destruction of mangrove canopy (Wanless et al. 1994). Carbon isotopic values evident in the Trout Creek core seem to support these conclusions. Four distinct negative isotopic excursions of up to $2.5 \%$ are apparent, suggesting large, yet temporally isolated, fluxes of mangrove-derived organic material coincident with documented hurricane events of 1919, 1935, 1960, and 1992 (Figure 4.8). This conclusion is supported by the work of Xu et al. (2007) on the same core, as peaks in the concentration of the mangrove organic biomarker, taraxerol, are evident at levels consistent with inputs related to Hurricanes Andrew and Donna (1992 and 1960). Unfortunately biomarker sampling resolution was not coincident with the earlier isotopic markers of hurricane influence found in the Trout Creek record, and since the duration of the storm fluxes are so temporally isolated, these storms were missed in the taraxerol record.

In the Ninemile Bank core, two negative isotopic excursions of approximately 2\%o can be seen in the $\delta^{13} \mathrm{C}$ record; the most recent appears to begin in the early 1990's coincident with Hurricane Andrew (Figure 4.5). A second period of carbon isotopic depletion is evident at the turn of the century, and persists for over 20 years. This earlier excursion may be related either to "The Great Freeze" of 1899 (Myers et al. 1986), a cold snap that resulted in a massive fall of mangrove foliage, or it may be the isotopic expression of the mangrove clearing for the purpose of building of the Flagler Railway (1907-1912; Wardlaw 2001). While Xu et al. (2007) did find slight increases in taraxerol 
fairly consistent in time with the events recorded in the bulk sedimentary isotopic record, the taraxerol concentrations found in the Ninemile Bank core are two orders of magnitude lower than those measured in the Trout Creek core and were interpreted to indicate low mangrove organic inputs in the western bay zone. Increases in $\mathrm{C}_{25} \mathrm{HBI}$ (highly branched isoprenoids, an organic biomarker for certain species of marine diatom; Xu et al. 2006, 2007) are also evident in intervals near 1900 and between 1985-1995 (Xu et al. 2007), so the negative carbon isotopic shifts could be related to increased phytoplankton/epiphytic diatom organic material inputs. Sediment elemental compositions in this core also seem to support algal sources, as this interval has lower organic carbon and nitrogen contents, coincident with increased sediment phosphorus. These concentrations could imply phytoplankton blooms as a source of organic material of different carbon isotopic composition, stimulated by increased phosphorus availability. Further, enriched $\delta^{15} \mathrm{~N}$ values over the 20 year interval could be indicative of increased surface nitrogen utilization during bloom conditions. In fact, diatom/algal blooms could be stimulated by nutrients released through degradation of mangrove organic matter inputs, thus both could contribute to the depleted $\delta^{13} \mathrm{C}$ values in these intervals. The Ninemile Bank carbon isotopic excursions differ from those preserved in the Trout Creek core in that they are persistent for up to 20 years in the open bay setting, whereas Trout Creek values, proximal to Taylor Slough freshwater discharge from the Everglades, suggest very short duration episodic events. This difference in time-span of preserved inputs is likely a function of residence time in bay versus creek settings. Presumably isotopically depleted carbon released by mangrove decomposition would be continuously recycled in the open bay, whereas freshwater flow in Trout Creek would serve to quickly 
flush dissolved components released via mangrove decomposition so preservation of the pulse signal in the sediment would be expected to be more restricted in time.

Interestingly, while all four major hurricanes preserved in the Trout Creek sediment organic isotopic record are not apparent in the isotopic records of the other Florida Bay cores, though three of the four are perhaps recorded in the nitrogen isotopic compositions of the Ninemile and Russell bank cores as subtle negative excursions of less than 1\%o (Figure 4.9). These negative perturbations might be related to nitrogen fixing cyanobacterial populations stimulated by detritus decay release of nutrients following storm events. This contention is supported by correlations with all four storm major events preserved in the organic carbon, nitrogen, and phosphorus content of the sediments (Figure 4.6). In the Ninemile Bank core there are peaks in all three elemental contents apparently coincident with the same 1919, 1935, 1960, and 1992 major storms. At Bob Allen Bank, minor increases in C:N ratios, coincident with decreases in N:P occur in intervals roughly concurrent with the 1960,1935 , and 1919 storms. These ratio changes are driven by small decreases in sediment N-content. Given the evidence in the ${ }^{210} \mathrm{~Pb}$ chronology that scouring and sediment transport is a significant influence on Bob Allen Bank, it is likely that sediment resuspension during the hurricane events facilitates oxic degradation of sedimentary organic matter and preferential N-removal. There are also $0.5 \%$ enrichments in $\delta^{15} \mathrm{~N}$ preserved in the 1960 and 1935 intervals which may also indicate preferential degradation of nitrogenous compounds during resuspension, as has been shown to occur in many studies of suspended particulate organic matter (Altabet 1988, Saino 1992, Macko et al. 1987, Holmes et al. 1997, Freudenthal et al. 2001). These 
results indicate that high magnitude storm events are differentially preserved in geochemical records depending on the individual character of local environments.

\subsection{CONCLUSIONS}

Changes in sediment geochemical characteristics over time at four coring locations along a central axial transect of Florida Bay provide a record of change over the past $150+$ years. Coincident shifts in first order trends and increasing fluctuation levels after 1910 at all sites indicate that bay-wide events and regional changes in the ecosystem have occurred, resulting in variations in organic material inputs and nutrient availability. Changes in sediment organic isotopic composition and elemental abundances exhibit high spatial heterogeneity and are dependent on the physical characteristics of different basins, not unlike the zones of similar influence model currently utilized to describe modern Florida Bay. Changes restricting circulation and altering of freshwater delivery through the Everglades watershed, including the construction of Flagler's Overseas Railroad in the early 1900's, Tamiami Trail in the 1930's, the South Dade Conveyance Canal System circa 1947, and the Water Conservation areas in 1965, have had profound impact on the Florida Bay system, and this is as evident in bulk sedimentary geochemical parameters as it is in very specific faunal assemblage or organic biomarker studies. Certainly, bulk organic material should not be overlooked, because while in some cases further proxies are necessary to clarify complex processes controlling these parameters, there is a wealth of historic information preserved in this material. Carbon isotopic data from all open bay cores seems to indicate predominance of seagrasses in terms of organic inputs to the sediments over the last 150 years. In addition, long term depletions in the $\delta^{13} \mathrm{C}$ of 
atmospheric and aqueous $\mathrm{CO}_{2}$, recognized in inorganic carbon proxies such as coral skeletons and shell material as well as in ice core and tree ring records, can also be observed in long term changes in the carbon isotopic composition of organic material. Gradients in relative nutrient limitation can be seen in preserved organic material isotopic compositions, particularly in sediment organic nitrogen, as this organic material is a product of the ambient conditions under which it was produced.

While the influence of anthropogenic disturbance since the turn of the century is clearly a dominant factor preserved in the recent sedimentary record of Florida Bay, bulk organic geochemistry data also record the occurrence of major hurricane activity, with negative excursions in both carbon and nitrogen isotopic values, confirming documentary evidence of hurricane landfalls of sufficient magnitude to cause significant damage to upstream mangrove wetlands. These impacts may provide a potential tracer for detecting hurricane events prior to historical documentation in high resolution sediment studies. 


\section{LITERATURE CITED}

Altabet, M.A. 1988. Variations in nitrogen isotopic composition between sinking and suspended particles: Implications for nitrogen cycling and particle transformation in the open ocean. Deep-Sea Research 35:535-554.

Altabet, M.A., and R. Francois. 1994. Sedimentary nitrogen isotopic ratio as a recorder of surface ocean nutrient utilization. Global Biogeochemical Cycles 8:103-116.

Andrews, T.J., and K.M. Abel. 1981. Kinetics and subunit interactions of ribulose bisphosphate carboxylase-oxygenase from the cyanobacterium, Synechococcus sp. Journal of Biological Chemistry 256:8445-8451.

Anderson, W.T., L.S.L Sternberg, M.C. Pinzon, T. Gann-Troxler, D.L. Childers, M. Duever. 2005. Carbon isotopic composition of cypress trees from South Florida and changing hydrologic conditions. Dendrochronologia 23:1-10.

Benedict, C.R., W.W.L. Wong, J.H.H. Wong. 1980. Fractionation of the stable isotopes of inorganic carbon by seagrasses. Plant Physiology 65:512-517.

Behringer, D.C., and M.J. Butler, IV. 2006. Stable isotope analysis of production and trophic relationships in a trophical marine hard-bottom community. Oecologia 148:334-341.

Boyer, J.N., J.W. Fourqurean, R.D. Jones. 1999. Seasonal and long term trends in the water quality of Florida Bay (1989-1997). Estuaries 22:417-430.

Boyer, J.N.; J.W. Fourqurean; R.D. Jones. 1997. Spatial characterization of water quality in Florida Bay and Whitewater Bay by multivariate analyses: Zones of similar influence. Estuaries 20:743-758

Brand, L. 2002. The transport of terrestrial nutrients to South Florida coastal waters. In: In: The Everglades, Florida Bay, and Coral Reefs of the Florida Keys: An Ecosystem Source Book. Eds: J.W. Porter and K.G. Porter. CRC Press, Boca Raton pp. 361-413.

Brewster-Wingard, G.L., J.R. Stone, C.W. Holmes. 2001. Molluscan faunal distribution in Florida Bay, past and present: An integration of down-core and modern data. Bulletin of Marine Science 44:199-231.

Brewster-Wingard, G.L., S.E. Ishman. 1999. Historical trends in salinity and substrate in Central Florida Bay: A paleoecological reconstruction using modern analogue data. Estuaries 22:269-283.

Butler, M.J., IV, J.H. Hunt, W.F. Herrnkind, M.J. Childress, R. Bertelsen, W. Sharp, T. Matthews, J.M. Field, and H.G. Marshall. 1995. Cascading disturbances in Florida Bay, USA: Cyanobacterial blooms, sponge mortality, and implications for 
juvenile spiny lobsters Panulirus argus. Marine Ecology Progress Series 129:119-125.

Calvert, S.E., B. Nielsen, M.R. Fontugne. 1992. Evidence from nitrogen isotope ratios for enhanced productivity during the formation of eastern Mediterranean sapropels. Nature 359:223-225.

Cialis, P, P.P. Tans, M. Troiler, J.W.C. White, R.J. Francey. 1995. A large northern hemisphere terrestrial $\mathrm{CO}_{2}$ sink indicated by the ${ }^{13} \mathrm{C} /{ }^{12} \mathrm{C}$ ratio of atmospheric $\mathrm{CO}_{2}$. Science 269:1098-1101.

Cronin, T.M., C.W. Holmes, G.L. Brewster-Wingard, S.E. Ishman, H.J. Dowsett, D. Keyser, N. Waibel. 2001. Historical trends in epiphytal ostracodes from Florida Bay: Implications for seagrass and macro-benthic algal variability. Bulletins of American Paleontology 361:159-197.

Davies, T.D., and A.D. Cohen. 1989. Composition and significance of the peat deposits of Florida Bay. Bulletin of Marine Science 44:387-398.

Davis, S.M. and J.C. Ogden (Eds.). 1994. Everglades: The Ecosystem and its Restoration. St. Lucie Press, Delray Beach, FL.

De Kanel, J., and J.W. Morse. 1978. The chemistry of orthophosphate uptake from seawater onto calcite and aragonite. Geochimica et Cosmochimica Acta 42:13351340.

Donders, T.H., P.M. Gorissen, F. Sangiorgi, H. Cremer, F. Wagner-Cremer, V. McGee. 2008. Three hundred year hydrological changes in a subtropical estuary, Rookery Bay (Florida): Human impact versus natural variability. Geochemistry, Geophysics, Geosystems 9:1-15.

Doyle, T.W., T.J. Smith III, and M.B. Robblee. 1995. Wind damage effects of Hurricane Andrew on mangrove communities along the SW coast of Florida, USA. Journal of Coastal Research 21:159-168.

Duarte, C.J. 1995. Submerged aquatic vegetation in relation to different nutrient regimes. Ophelia 41:87-112.

Evans, S.L., W.T. Anderson, F.J. Jochem. 2006. Spatial variability in Florida Bay particulate organic matter composition: Combining flow cytometry with stable isotope analysis. Hydrobiologia 569:151-165.

Fleming, M., G. Lin and L.S.L. Sternberg. 1990. Influence of mangrove detritus in an estuarine system. Bulletin of. Marine Science. 47: 663-669

Flynn, W.W. 1968. The determination of polonium-210 in environmental materials. Analytica Chimica Acta 43:121-131. 
Fourqurean, J.W., S.P. Escorcia, W.T. Anderson, J.C. Zieman. 2005. Spatial and seasonal variability in elemental content $\delta^{13} \mathrm{C}$ and $\delta^{15} \mathrm{~N}$ of Thalassia testudinum from South Florida and its implications for ecosystem studies. Estuaries 28:447461.

Fourqurean, J.W., and J.E. Schrlau. 2003. Changes in nutrient content and stable isotope ratios of $\mathrm{C}$ and $\mathrm{N}$ during decomposition of seagrasses and mangrove leaves along a nutrient availability gradient in Florida Bay, USA. Chemistry and Ecology 19:373-390.

Fourqurean, J.W., and J.C. Zieman. 2002. Seagrass nutrient content reveals regional patterns of relative availability of nitrogen and phosphorus in the Florida Keys, USA. Biogeochemistry 61:229-245.

Fourqurean, J.W., and M.B.Robblee. 1999. Florida Bay: a history of recent ecological changes. Estuaries 22:345-357.

Fourqurean, J.W., R.D. Jones, J.C. Zieman. 1993. Processes influencing water column nutrient characteristics and phosphorus limitation of phytoplankton biomass in Florida Bay, FL, USA: Inferences from spatial distributions. Estuarine, Coastal, and Shelf Science 36:295-314.

Fourqurean, J.W., G.V.N. Powell, J.C. Zieman. 1992a. Relationships between porewater nutrients and seagrasses in a subtropical carbonate environment. Marine Biology 114:57-65.

Fourqurean, J.W., and J.C. Zieman. 1992b. Phosphorus limitation of primary production in Florida Bay, evidence from C:N:P: ratios of the dominant seagrass, Thalassia testudinum. Limnology and Oceanography 37:162-171.

Francey, R.J., C.E. Allison, D.M. Etheridge, C.M. Trudinger, I.G. Enting, M. Leuenberger, R.L. Langenfields, E. Michel, L.P. Steele. 1999. A 1000-year high precision record of $\delta^{13} \mathrm{C}$ in atmospherioc $\mathrm{CO}_{2}$. Tellus B 51:170-193.

Francey, R.J., and Allison, C.E., 1996, In situ carbon 13 and oxygen 18 ratios of atmospheric $\mathrm{CO}_{2}$ from Cape Grim, Tasmania, Australia: 1982-1993. In: Trends: A Compendium of Data on Global Change: Oak Ridge, Tenn., USA, Carbon Dioxide Information Analysis Center, Oak Ridge National Laboratory. Available from $<$ http://cdiac.esd.ornl.gov/trends/co2/capegrim.html $>$.

Francois, R., M.A. Altabet, and L.H. Burkle. 1992. Glacial to interglacial changes in surface nitrate utilization in the Indian sector of the southern ocean as recorded by sediment $\delta^{15} \mathrm{~N}$. Paleoceanography 7:589-606.

Frankovich, T.A., and J.W. Fourqurean. 1997. Seagrass epiphyte loads along a nutrient availability gradient, Florida Bay. Marine Ecology Progress Series 159:37-50. 
Freudenthal, T., T. Wegener, F. Wenzhofer, M. Zabel, G. Wefer. 2001. Early diagenesis of OM from sediments of the eastern subtropical Atlantic: evidence from stable nitrogen and carbon isotopes. Geochimica et Cosmochimica Acta 65:1795-1808.

Guo, L., T. Tanaka, D. Wang, N. Tanaka, A. Murata. 2004. Distributions, speciation and stable isotope composition of organic matter in the southeastern Bering Sea. Marine Chemistry 91:211-226.

Halley, R.B., and L.M. Roulier. 1999. Reconstructing the history of eastern and central Florida Bay using mollusk-shell isotope records. Estuaries 22:358-368.

Herczeg, A.L., A.K. Smith, J.C. Dighton. 2001. A 120 year record of changes in nitrogen and carbon cycling in Lake Alexandria, South Australia: C:N, $\delta^{15} \mathrm{~N}$ and $\delta^{13} \mathrm{C}$ in sediments. Applied Geochemistry 16:73-84.

Holmes, C.W., J Robbins, R. Halley, M. Bothner, M. Ten Brink, M. Marot. 2001. Sediment dynamics of Florida Bay mud banks on a decadal time scale. Bulletins of American Paleontology 361:31-40.

Holmes, M.E., R.R. Schneider, P.J. Muller, M. Segl, and G. Wefer. 1997. Reconstruction of past nutrient utilization in the eastern Angola Basin based on sedimentary ${ }^{15} \mathrm{~N} /{ }^{14} \mathrm{~N}$ ratios. Paleoceanography 12:606-614.

Huvane, J.K., and S.R. Cooper. 2001. Diatoms as indicators of environmental change in sediment cores from Northeastern Florida Bay. Bulletin of Marine Science 44:145-158.

Kang, W.J., And J.H. Trefry. 2003. Retrospective analysis of the impacts of major hurricanes on sediments in the lower Everglades and Florida Bay. Environmental Geology 44:771-780.

Kieckbusch, D.K., M.S. Koch, J.E. Serafy, and W.T. Anderson. 2004. Trophic linkages among primary producers and consumers in fringing mangroves of subtropical lagoons. Bulletin of Marine Science 74:271-285.

Lapointe, B.E. 1987. Phosphorus and nitrogen-limited photosynthesis and growth of Gracilaria tikvahiae (Rhodophyceae) in the Florida Keys: an experimental field study. Marine Biology 93:561-568.

Lapointe, B.E., and J.D. O'Connell. 1989. Nutrient enhanced growth of Cladophora prolifera in Harrington Sound, Bermuda: Eutrophication of a confined, phosphorus-limited marine ecosystem. Estuarine, Coastal, and Shelf Science 28:347-360.

Lapointe, B.E., and M.W. Clark. 1992. Nutrient inputs from the watershed and coastal eutrophication in the Florida Keys. Estuaries 15:465-476. 
Lapointe, B.E., D.A. Tomasco, and W.R. Matzie. 1994. Eutrophication and the trophic state classification of seagrass communities in the Florida Bay Keys. Bulletin of Marine Science 54:696-717.

Lamb, A.L., G.P. Wilson, M.J. Leng. 2006. A review of coastal paleoclimate and relative sea-level reconstructions using $\delta^{13} \mathrm{C}$ and $\mathrm{C} / \mathrm{N}$ ratios in organic material. Earth-Science Reviews 75:29-57.

Lamb, A.L., C.H. Vane, G.P. Wilson, J.G. Rees, V.L. Moss-Hayes. 2007. Assessing $\delta^{13} \mathrm{C}$ and $\mathrm{C} / \mathrm{N}$ ratios from organic material in archived cores as Holocene sea level and palaeoenvironmental indicators in the Humber Estuary, UK. Marine Geology 244:109-128.

Lee, T, E. Johns, D. Wilson, E. Williams, and N. Smith. 2002. Transport processes linking South Florida coastal ecosystems. In: The Everglades, Florida Bay, and Coral Reefs of the Florida Keys: An Ecosystem Source Book. Eds: J.W. Porter and K.G. Porter. CRC Press, Boca Raton

Light, S.S., and J.W. Dineen. 1994. Water control in the Everglades: A historical perspective. In: S.M. Davis and J.C. Ogden (Eds.) Everglades: The Ecosystem and its Restoration. pp. 47-84. St. Lucie Press, Delray Beach, FL.

Lin, G., T. Banks, L.S.L. Sternberg. 1991. Variation in $\delta^{13} \mathrm{C}$ values for the seagrass Thalassia testudinum and its relations to mangrove carbon. Aquatic Botany 40:333-341.

Macko, S.A., M.H. Engel, P.L. Parker. 1993. Early diagenesis of OM in sediments: Assessment of mechanisms and preservation by the use of isotopic molecular approaches. pp. 211-224. In: M.H. Engel, S.A. Macko, eds. Organic Geochemistry: Principles and Applications. Plenum Press, New York.

MacPherson, B.F., and R. Halley. 1996. The South Florida Environment: A region under stress. U.S. Geological Survey Circular 1334. 61pp.

McIvor, C.C., J.A. Ley, R.D. Bjork. 1994. Changes in freshwater inflow from the Everglades to Florida Bay including effects on biota and biotic processes. In: S.M. Davis and J.C. Ogden (Eds.) Everglades: The Ecosystem and its Restoration. St. Lucie Press, Delray Beach, FL.

Meyers, P.A. 1997. Organic geochemical proxies of paleoceanographic, paleolimnologic, and paleoclimatic processes. Organic Geochemistry 27:213250 .

Meyers, P.A. 1994. Preservation of elemental and isotopic source identification of sedimentary organic matter. Chemical Geology 114:289-302 
Minoura, K., K. Hoshino, T. Nakamura, E. Wada. 1997. Late Pleistocene-Holocene paleoproductivity circulation in the Japan Sea: Sea level control on $\delta^{13} \mathrm{C}$ and $\delta^{15} \mathrm{~N}$ records of sediment organic material. Palaeoceanography, Palaeoclimatoogy, Palaeoecology 135:41-50.

Mumford, P.L. 1999. The effects of environmental stress and primary productivity on food chain length in Florida Bay. Masters Thesis, Florida International University, Miami, FL, USA.

Nelson, T.A., H.R. Wanless, J.H. Trefry, W.J. Kang, S. Metz, C. Alvarez-Zarikian, T. Hood, P.K. Swart, G. Ellis, P. Blackwelder, L. Tedesco, C. Slouch, J.F. Pachut, M. O'Neal. 2002 Linkages between the South Florida peninsula and coastal zone: A sediment based history of natural and anthropogenic influences. In: The Everglades, Florida Bay, and Coral Reefs of the Florida Keys: An Ecosystem Source Book. Eds: J.W. Porter and K.G. Porter. CRC Press, Boca Raton pp. 415449.

Ogrinc, N., G. Fontolan, J. Faganeli, S. Covelli. 2005. Carbon and Nitrogen isotopic compositions of organic matter in coastal marine sediments (Gulf of Trieste, North Adriatic Sea): indicators of sources and preservation. Marine Chemistry 95:163-181.

Orem, W.H., C.W. Holmes, C. Kendall, H.E. Lerch, A.L. Bates, S.R. Silva, A. Boylan, M. Corum, M. Marot, C. Hedgman. 1999. Geochemistry of Florida Bay sediments: Nutrient history at five sites in eastern and central Florida Bay. Journal of Coastal Research 15:1055-1071.

Phlips, E.J., S. Badylak. 1996. Spatial variability in phytoplankton sanding crop and composition in a shallow tropical inner-shelf lagoon, Florida Bay, USA. Bulletin of Marine Science 58:203-216.

Prahl, F.G., G.J deLange, S. Scholten, G.L. Cowie. 1997. A case of post depositional aerobic degredation of terrestrial OM in turbidite deposits from the Madeira Abyssal Plain. Organic Geochemistry 27:141-152.

Press, W.H., B.P. Flannary, S.A. Teukolsky, V.T. Vettering. 1989. Numerical recipes: The art of scientific computing. Cambridge University Press, New York, NY, pp 702 .

Redfield, A.C. 1934. On the proportion of organic derivatives in sea water and their relation to the composition of plankton. In: James Johnstone Memorial Volume, Univ. Liverpool, pp. 176-192.

Revelle, R. and H. Suess. 1957. Carbon dioxide exchange between atmosphere and ocean and the question of an increase of atmospheric $\mathrm{CO}_{2}$ during the past decades. Tellus 9:18. 
Rice, D.L., and R.B. Hanson. 1984. A Kinetic model for detritus nitrogen: Role of the associated bacteria in nitrogen accumulation. Bulletin of Marine Science 35:326340.

Robblee, M.B., T.R. Barber, P.R. Carlson, Jr., M.J. Durako, J.W. Fourqurean, L.K. Muehlstein, D. Porter, L.A. Yarbro, R.T. Zieman, J.C. Zieman. 1991. Mass mortality of the tropical seagrass Thalassia testudinum in Florida Bay (USA). Marine Ecology Progress Series 71:297-299.

Rudnick, D., C. Madden, S. Kelly, R. Bennett, K, Cunniff. 2006. Report on algae blooms in Eastern Florida Bay and Southern Biscayne Bay. South Florida Water Management District. 27p.

Rudnick, D.T., Z. Chen, D.L. Childers, J.N. Boyer, and D.T. Fontaine. 1999. Phosphorus and nitrogen inputs to Florida Bay: The importance of the Everglades watershed. Estuaries 22:398-416.

Ruttenberg, K.C., and M.A. Goni. 1997. Phosphorus distribution, C:N:P ratios, and $\delta^{13} \mathrm{C}_{\mathrm{OC}}$ in Arctic, temperate, and tropical coastal sediments: tools for characterizing bulk sedimentary organic matter. Marine Geology 139:123-145.

Saino T., 1992. ${ }^{15} \mathrm{~N}$ and ${ }^{13} \mathrm{C}$ natural abundance in suspended particulate organic matter from a Kuroshio warm-core ring. Deep-Sea Research 39:347-362

Scholl, D.W., 1964. Recent sedimentary record in mangrove swamps and rise in sea level over the southwestern coast of Florida, Parts I and II. Journal of Marine Geology 1:344-366.

Short, F.T., W.C. Dennison, and D.G. Capone. 1990. Phosphorus-limited growth of the tropical seagrass Suringodium filiforme in carbonate sediments. Marine Ecology Progress Series 62:160-174.

Smith, T.J., J. H. Hudson, M.B. Robblee, G.V.N. Powell, P.J. Ishdale. 1989. Freshwater flow into Florida Bay; a historical reconstruction based on fluorescent banding in the coral Solenastrea bournoni. Bulletin of Marine Science 44:274-282.

Swart, P.K., S. Therrold, A. Eisenhauer, B. Rosenheim, C.G.A. Harrison, M. Grammer, C. Latkoczy. 2002. Intra-annual variation in the stable oxygen, carbon, and trace element composition of sclerosponges. Paleoceanography 17:792-808

Swart, P.K., R.M. Price, L. Greer. 2001. The relationship between stable isotopic variations $(\mathrm{O}, \mathrm{H}$, and $\mathrm{C})$ and salinity in waters and corals from environments in South Florida: Implications for reading the paleoenvironmental record. Bulletins of American Paleontology 361:17-30.

Swart, P.K., G.F. Healy, R.E. Dodge, p. Kramer, J.H. Hudson, R.B. Halley, M.B. Robblee. 1996. The stable oxygen and carbon isotopic record from a coral 
growing in Florida Bay: a 160 year record of climatic and anthropogenic influence. Palaeogeography, Palaeoclimatology, Palaeoecology 123:219-237.

Swart, P.K., G. Healy, L. Greer, M. Lutz, A. Saeid, D. Anderegg, R.E. Dodge, D. Rudnick. 1999. The use of chemical records in coral skeletons to ascertain past environmental conditions in Florida Bay. Estuaries 22:384-397.

Tabb, D.C., and A.C. Jones. 1962. Effect of Hurricane Donna on the aquatic fauna of north Florida Bay. Transactions of the American Fisheries Society 91:375-397.

Teranes, J.L., and S. Bernasconi. 2000. The record of nitrate utilization and productivity limitation provided by $\delta^{15} \mathrm{~N}$ values in lake organic matter - A study of sediment trap and core sediments from Baldeggersee, Switzerland. Limnology and Oceanography 45:801-813.

Tyson, R.V. 1995. Sedimentary organic matter: Organic facies and palynofacies. Chapman and Hall, London.

Valiela, I., J.M. Teal, S.D. Allen. 1985. Decomposition of salt march ecosystems: the phases and major factors affecting disappearance of above-ground organic matter. Journal of Experimental Marine Biology and Ecology 89:29-54.

Wanless, H.R., R.W., Parkinson, and L.P. Tedesco. 1994. Sea level control on stability of Everglades wetlands. In: S.M. Davis and J.C. Ogden (Eds.) Everglades: The Ecosystem and its Restoration. pp 199-224. St. Lucie Press, Delray Beach, FL.

Wardlaw, B.R. 2001. Introduction to paleoecological studies of South Florida and the implications for land management decisions. Bulletins of American Paleontology 361:5-16.

Williams, A.J., and J.C. Trexler. 2006. A preliminary analysis of the correlation of foodweb characteristics with hydrology and nutrient gradients in the southern Everglades. Hydrobiologia 569:493-504.

Wozniak, J.R., D.L. Childers, W.T. Anderson, D.T. Rudnick, and C.J. Madden. 2008. An in situ mesocosm method for quantifying nitrogen cycling rates in oligotrophic wetlands using N-15 tracer techniques. Wetlands 28:502-512.

Xu. Y., C.W. Holmes, R. Jaffe. 2007. Paleoenvironmental assessment of recent changes in Florida Bay, USA: A biomarker based study. Eastuarine, Coastal, and Shelf Science 73:201-210.

Xu, Y., R. Jaffe, A. Wachnicka, E.E. Gaiser. 2006. Occurrence of $\mathrm{C}_{25}$ highly branched isoprenoids (HBIs) in Florida Bay: Paleoenvironmental indicators of diatomderived organic matter inputs. Organic Geochemistry 37:847-859. 
Yamamuro, M. 2000. Chemical tracers of sediment organic matter origins in two coastal lagoons. Journal of Marine Systems 26:127-134.

Zarikian, C.A.A., P.K. Swart, T. Hood, P.L. Blackwelder, T. Nelson, C. Featherstone. 2001. A century of environmental variability in Oyster Bay using ostracode ecological and isotopic data as paleoenvironmental tools. Bulletins of American Paleontology 361:133-143

Zieman, J.C., J.W. Fourqurean, R.L. Iverson. 1989. Distribution, abundance, and productivity of seagrasses and macroalgae in Florida Bay. Bulletin of Marine Science 44:292-311.

Zieman, J.C., R.L. Iverson, and J.C. Ogden. 1984. Herbivory effects on Thalassia testudinum leaf growth and nitrogen content. Marine Ecology Progress Series $15: 151-158$ 
CHAPTER 5

\section{CONCLUSIONS AND FUTURE STUDIES}




\subsection{CONCLUSION}

In coastal South Florida, long term management plans for restoration of natural flow conditions through the Everglades increase the importance of understanding potential nutrient impacts of increased freshwater delivery on coastal biogeochemistry. Part of the impetus behind the isotopic studies documented here lay in exploring spatial and temporal variability in planktonic community composition and relationships to nutrient parameters in light of the variability observed over ten years of isotopic monitoring in benthic seagrass communities (Fourqurean et al. 2005) and in consideration of changes in biotic community structure evident over the last three decades, with increased incidence of plankton blooms and declining seagrass densities in many areas (Fourqurean and Robblee 1999). The further objective of this work was to examine the sediment record in Florida Bay to assess the preservation of variability in organic material over a longer time scale. Thus the main goal of this dissertation was to examine components of the isotopic systematics of the South Florida marine system, at a variety of time scales. At the process level, OM stable isotopic values were applied to assess nutrient acquisition mechanisms in a single transient cyanobacterial bloom event. From a longer term seasonal point of view, isotopic values demonstrated a high level of spatial and temporal variability in POM, supporting previous work characterizing the significance of hydrodynamic regime as a control on coastal processes. Increasing the scale further, geochemical data was utilized to assess organic matter source and identify markers of disturbance in the last century. The unifying feature of the isotopic data presented here is the high level of variability exhibited on all time scales. 


\subsection{ISOTOPIC VARIABILITY IN POM}

The isotopic composition of POM in near-shore and estuarine settings provides important information about ambient environmental conditions, biotic community structure, and biogeochemical cycling within the system. This information may be used to infer changes in primary productivity and water quality parameters in increasingly environmentally sensitive coastal settings and in the case of South Florida, could become a valuable tool to evaluate future downstream impacts of modifications to Everglades hydrology.

\subsubsection{Nitrogen fixation in transient cyanobacterial blooms}

In the present study, OM stable isotopic values were applied to assess nutrient acquisition mechanisms in a transitory cyanobacterial bloom event, demonstrating spatial heterogeneity across a relatively short distance between northeast and western Florida Bay in process-controlled OM isotopic character. In many marine settings, carbon and nitrogen isotopic signatures have been interpreted in terms of surface nutrient utilization and productivity levels (Altabet and Francois 1994, Altabet 1988), yet the isotopic data in the first part of the work presented here demonstrates nitrogen isotopic depletion, rather than enrichment, coincident with a surface plankton bloom. This isotopic depletion has implications regarding the importance of biologically fixed nitrogen as a nutrient source during bloom events, particularly in nitrogen-limited marine environments. While these observations are not revolutionary, N-fixing plankton blooms are of course widespread, geochemical documentation of spatially isolated new nitrogen inputs to the coastal system are relevant in terms of understanding nutrient cycling and delivery in the local 
coastal environment. This situation becomes particularly significant when the connection between phosphorus availability and cyanobacterial bloom organisms capable of supporting their own nitrogen demand is considered in terms of changing Everglades hydrology. As has been seen in the persistent Southern Biscayne Bay/Northeastern Florida Bay plankton bloom (2005-present) any change in phosphorus delivery (for example a road construction project and/or a major pulse in hurricane frequency) may upset the ecosystem balance, opening the system to pervasive ecological disturbance (Rudnick et al. 2006). In the coastal Florida carbonate platform environment phosphorus is the limiting nutrient for primary productivity (Fourqurean et al. 1993), however that could change if restoration of Everglades flows served to deliver higher levels of agricultural runoff into the coast al zone. Any perturbation in phosphorus availability could support bloom forming organisms either in zones characterized by high or low nitrogen availability, with species assemblages adapted to appropriate $\mathrm{N}$-acquisition mechanisms.

\subsubsection{Spatial and temporal isotopic variability in size-fractionated POM}

From a seasonal point of view, POM isotopic values exhibited a high level of spatial and temporal variability, yet this variability was distributed in a pattern supporting previous work characterizing the significance of hydrodynamic regime as a control on coastal nutrient processes and ecology (Boyer et al. 1997). Clearly planktonic communities respond to seasonal changes in environmental parameters, although driving mechanisms vary in space and time. In the case of the South Florida coastal zone, differences in all environmental parameters are dependent on the hydrodynamic regime 
of various areas in terms of geomorphological constraints and physical mechanisms of nutrient delivery and transport (Rudnick et al. 1999, Boyer et al. 1997). Geochemical cycles in POM fractions reflect these patterns in hydrodynamic regime, showing seasonal changes controlled by factors specific to localized zones of influence and as a result, exhibit a remarkable level of isotopic heterogeneity. Significant differences were observed between both size classes and sampling locations in terms of isotopic values and seasonal patterns in POM; $\delta^{13} \mathrm{C}$ values varied by up to $22 \%$ while $\delta^{15} \mathrm{~N}$ values showed seasonal changes of up to 7\%o. Interestingly, the range in isotopic values observed in POM varying on both spatial and seasonal scales exceeds that exhibited by benthic seagrasses in the region (Fourqurean et al. 2005), suggesting that the variation in POM isotopic composition is not entirely driven by particulate contributions from the benthic community. Furthermore, the seasonal variations in POM isotopic character documented here are of a magnitude equal to the long term changes observed in sedimentary records spanning geologic time scales on the order of millions of years (Haug et al. 2000, Minoura et al. 1997), yet were observed on a single carbonate platform over just two years of seasonal cycling. The result is autochthonous OM that is geochemically variable even over short distances, which has implications to future study attempting to characterize coastal processes without well distributed sampling schemes. As well, the level of spatial and temporal variability of isotopic composition, inconsistency in isotopic values between size classes, and also differences between size fractionated and bulk POM samples have implications for current assumptions regarding the interpretation of bulk filtered POM samples as they are applied to understanding food-web studies, studies of organic matter sources to the coastal zone, and natural tracer 
experiments examining anthropogenic influences in the coastal environment. All these studies must take into account spatial and temporal changes in the stable isotopic composition of POM when interpreting relationships and patterns.

\subsubsection{Limitations of the POM time-series}

Despite the importance of POM in aquatic ecosystems, studies of POM are hindered by several methodological constraints. One of the most important is that POM is highly heterogeneous, consisting of living and dead cells, fecal pellets, marine snow aggregates, organically coated mineral grains, and other materials, each of which may exhibit different spatial and temporal variations depending on source and chemical transformations (Minor and Nallathamby 2004). Separating particulates on the basis of size does not alleviate difficulties inherent in understanding the geochemical character of a variable mixture of particle sources. For example, while the $>150 \mu \mathrm{m}$ size fractionation can be operationally defined as the "zooplankton" fraction, in fact larval zooplankton can be captured in smaller size classes, which was observed microscopically in the particulate fractions collected. Additionally, separating by particle size also does not allow the separation of living plankton from detritus particles of uniform size. Advances have been made that help alleviate these sample corruptions, particularly for POM in the piconanometer range quantified with flow cytometry. Minor and Nallathamby (2004) utilized cell sorting features available on certain flow cytometers in conjunction with isotopic ratio mass spectrometry to obtain more specific isotopic values. Obviously data are limited by the capabilities of available instrumentation. Manual sorting of larger size fractions is one possible solution to the mixed isotopic signal, however would require 
much larger sample volumes and a very significant time commitment in order to sort particles into individual samples of sufficient mass for further geochemical analyses.

Further limitations of the dataset are evident from a statistical point of view. While the sampling design employed provided statistically valid descriptive data illustrating seasonal changes in POM geochemical, this design was less suited to correlation analyses between the isotopic cycles either within or between the size classes, or between the size classes and various environmental parameters potentially affecting them. Correlation requires high frequency sampling and an evenly spaced representation along a given physical or chemical gradient. Cyclic phenomena such as seasonal productivity cycles, nutrient drawdown, and episodic change, either in nutrient delivery or climate patterns, undermine correlations where there are lags in responses (Rolff 2000, Savoye et al. 2003). Improving sampling resolution from quarterly to monthly or even biweekly would increase not only the potential for correlation analyses, but also would of course generate much clearer seasonal patterns, as a single sample collected at 3 month intervals is unlikely to truly represent a seasonal mean in terms of geochemical character. So many variables may influence the composition of POM at any given location, including weather (wind and precipitation), tidal forcing, biological species succession, episodic nutrient delivery, and probably a host of other factors, that it is unrealistic to expect a single sampling interval to represent average conditions. Additional statistical limitation was incurred by logistical constraints on sampling. Available time and infrastructure on site during each sampling interval allowed for the collection of one sizefractionated sample per site. While over 300 samples were collected to build the isotopic time series, lack of replication precluded between site comparisons of individual seasons. 


\subsection{FLORIDA BAY SEDIMENTARY RECORDS}

One of the main objectives of this research was to apply new understanding of modern variability in POM isotopic systematics to increase understanding of the sedimentary record in Florida Bay. While the high level of variability observed in POM isotopic signatures is complicated in terms of direct application to the sediment record, these data do have some significant implications to understanding preserved OM. Isotopic signals suggesting nitrogen fixation in western Florida Bay and the strong connectivity between seasonal patterns in POM isotopic character and hydrodynamic regime convolute conventionally accepted paradigms of sediment record interpretation. Relative $\delta^{15} \mathrm{~N}$ enrichment or depletion is not necessarily indicative of surface nitrogen utilization in situations where nitrogen is not the limiting nutrient (Teranes and Bernasconi 2000, Lehmann et al. 2004), nor when changes in nitrogen fixation or denitrifcation rates exert influence over the isotopic character of nitrogen pools (Haug et al. 2000, Ren et al. 2008). Thus even process-oriented short-term observations of isotopic fractionation or microbial nitrogen cycling shifts are in fact connected to long term sediment records.

Autochthonous OM produced in the various hydrodynamic zones of influence around South Florida exhibits a remarkable level of isotopic heterogeneity. Also, this magnitude of spatial and temporal fluctuation in isotopic composition has been documented, albeit over a smaller range in isotopic values, in seagrasses (Anderson and Fourqurean 2003, Fourqurean et al. 2005), and in marine algae (Lapointe et al. 2004, Lapointe et al. 2005). Recent work has demonstrated linkages between variability in 
water column processes, particularly in terms of nitrogen cycling and the isotopic character of POM, with sinking particles and preserved sedimentary organic material (Haug et al. 2000, Teranes and Bernasconi 2000, Ren et al. 2008), thus the high degree of heterogeneity apparent in both planktonic and benthic OM production from the South Florida coastal zone can be expected to control the character of OM preserved in sediments. Indeed, similar to the spatial heterogeneity evident in the modern setting in terms of the isotopic character of $\mathrm{OM}$, cores collected from relatively closely spaced locations in Florida Bay show a high level of discordance in isotopic values, as well as elemental compositions. The $\delta^{13} \mathrm{C}$ values from all the open Florida Bay coring locations indicate the predominance of seagrasses as OM source, however values are slightly depleted, implying mixing with marine planktonic OM sources. The $\delta^{13} \mathrm{C}$ of sediment organic material proximal to the Everglades outflow in northeastern Florida Bay is further depleted, indicating terrestrial OM represents a significant component of perhaps a three-end member mixing model combining seagrass with planktonic OM, in addition to terrestrial inputs. While these source distributions are shown with relative clarity by $\delta^{13} \mathrm{C}$ records, $\delta^{15} \mathrm{~N}$ values in bulk sediment OM seemed to reflect some of the processes evident in the modern POM studies. Nitrogen isotopic values in western Florida Bay sediments were depleted relative to all other coring locations, similar to patterns observed in the POM isotopic signal. Organic matter inputs related to the planktonic nitrogen fixation observed in the western zone generated a pervasive signal evident over time in the sedimentary record. The central and northeastern Florida Bay core sedimentary organic nitrogen records demonstrate the importance of hydrodynamic setting in OM geochemical character, with differences in nitrogen isotopic values shown between basins 
influenced by varying degrees of hydrologic restriction (i.e. Russell Bank is in a more isolated basin and had more enriched $\delta^{15} \mathrm{~N}$ values over the length of the core record examined than in the less isolated Bob Allen Bank core record).

Superimposed on the spatial heterogeneity evident in sediment OM geochemical records are the impacts of major anthropogenic changes to the system in the last century. Coincident shifts in first-order trends and increasing fluctuation levels after 1910 at all sites indicate bay-wide events and regional changes in the ecosystem occurred coincident with railroad construction in the Florida Keys, resulting in variations in organic material inputs and nutrient availability. Further, perhaps more subtle, yet equally pervasive, are shifts concurrent with the large changes in Everglades drainage systems circa 1950. The expression of such changes in terms of sediment organic isotopic composition and elemental abundances exhibit high spatial heterogeneity and are dependent on the physical characteristics of different basins, not unlike the zones of similar influence model currently utilized to describe modern Florida Bay. Additionally, Florida Bay sediments preserve a record of major climate disturbance over the centurial time scale. Sediment geochemistry was found to record incidence of major storms of the last century, but again, the expression of the geochemical impacts varies with location and presumably hydrodynamic regime.

\subsection{FUTURE STUDIES}

The unifying feature of the isotopic data presented here is the high level of variability exhibited on all time scales, from isolated instances of process level variability in POM isotopic composition through seasonal and more widespread spatial variations in 
POM to the geochemical imprint of anthropogenic and climatic events over the course of the last century. As such, this work presents a myriad of potential avenues for future geochemical study. From the process perspective, further work examining other indicators of $\mathrm{N}$-fixation, such as nitrogenase enzymatic assays or mesocosm experimentation measuring uptake of isotopically labeled $\mathrm{N}_{2}$ gas, is needed to elucidate the role fixed nitrogen plays in South Florida coastal environments. Additionally, given linkages evident in sedimentary records from several ocean basins, including the nearby Bahamas Banks setting (Ren et al. 2008), between $\mathrm{N}$-fixation and denitrification in both modern and sedimentary records, it seems the poor understanding of denitrification in the various environments of the Everglades-mangrove ecotone-estuary-reef continuum of the South Florida coastal zone is a significant missing portion in understanding of the local nitrogen cycle. From the seasonal perspective, it is abundantly clear that the high level of spatial heterogeneity in POM from the coastal zone seen in this study of just ten locations in Florida Bay and the Florida Keys national Marine Sanctuary could be expanded to a more comprehensive list of locations, perhaps with greater coverage in hydrodynamic zones unassessed in the present study. Additionally, quarterly sampling resolution is insufficient to fully characterize seasonal variation, due to temporally isolated impacts of weather patterns and tidal influences. Higher sampling resolution might allow better correlation between water quality parameters and changes in POM geochemical character. 


\section{LITERATURE CITED}

Altabet, M.A. 1988. Variations in nitrogen isotopic composition between sinking and suspended particles: Implications for nitrogen cycling and particle transformation in the open ocean. Deep-Sea Research 35:535-554.

Altabet, M.A., and R. Francois. 1994. Sedimentary nitrogen isotopic ratio as a recorder of surface ocean nutrient utilization. Global Biogeochemical Cycles 8:103-116.

Boyer, J.N.; J.W. Fourqurean, R.D. Jones. 1997. Spatial characterization of water quality in Florida Bay and Whitewater Bay by multivariate analyses: Zones of similar influence. Estuaries 20:743-758

Fourqurean, J.W., R.D. Jones, J.C. Zieman. 1993. Processes influencing water column nutrient characteristics and phosphorus limitation of phytoplankton biomass in Florida Bay, FL, USA: Inferences from spatial distributions. Estuarine, Coastal, and Shelf Science 36:295-314.

Fourqurean, J.W., and M.B.Robblee. 1999. Florida Bay: a history of recent ecological changes. Estuaries 22:345-357.

Fourqurean, J.W., S.P. Escorcia, W.T. Anderson, J.C. Zieman. 2005. Spatial and seasonal variability in elemental content $\delta^{13} \mathrm{C}$ and $\delta^{15} \mathrm{~N}$ of Thalassia testudinum from South Florida and its implications for ecosystem studies. Estuaries 28:447461.

Haug, G.H., T.F. Pederson, D.M. Sigman, S.E. Calvert, B. Nielsen, and L.C. Peterson. 2000. Glacial/interglacial variations in production and nitrogen fixation in the Cariaco Basin during the last 580 kyr. Paleoceanography 13:427-432.

Lapointe, B.E., P.J. Barile, M.M. Littler, D.S. Littler. 2005. Macroalgal blooms on Southeast Florida Coral Reefs II. Cross-shelf determination of N-sources indicated widespread assimilation of sewage Nitrogen. Harmful Algae 4:11061122.

Lapointe, B.E., P.J. Barile, and W.R. Matzie. 2004. Anthropogenic nutrient enrichment of seagrass and coral reef communities in the Lower Florida Keys: Discrimination of local versus regional nitrogen sources. Journal of Experimental Marine Biology and Ecology 308:23-58.

Lehmann, M.F., S.M. Bernasconi, J.A. McKenzie, A. Barbieri, M. Simona, M. Veronesi. 2004. Seasonal variation of the $\mathrm{d}^{13} \mathrm{C}$ and $\mathrm{d}^{15} \mathrm{~N}$ of particulate and dissolved carbon and nitrogen in Lake Lugano: Constraints on biogeochemical cycling in a eutrophic lake. Limnology and Oceanography 49:415-429.

Minor, E. C., P.S. Nallanthamby. 2004. “Cellular” vs. “detrital” POM: A preliminary analysis uding fluorescent stains, flow cytometry, and mass spectrometry. Marine Chemistry 92:9-21. 
Minoura, K., K. Hoshino, T. Nakamura, E. Wada. 1997. Late Pleistocene-Holocene paleoproductivity circulation in the Japan Sea: Sea level control on $d^{13} \mathrm{C}$ and $\mathrm{d}^{15} \mathrm{~N}$ records of sediment organic material. Palaeoceanography, Palaeoclimatoogy, Palaeoecology 135:41-50.

Ren, H., D.M. Sigman, A.N. Meckler, B. Plessen, R.S. Robinson, Y. Rosenthal, G.H. Haug. 2009. Foraminiferal isotope evidence of reduced nitrogen fixation in the Ice Age Atlantic Ocean. Science 323:244-248.

Rolff, C. 2000. Seasonal variation in $\delta^{13} \mathrm{C}$ and $\delta^{15} \mathrm{~N}$ of size-fractionated plankton at a coastal station in the northern Baltic proper. Marine Ecology Progress Series 203:47-65.

Rudnick, D.T., Z. Chen, D.L. Childers, J.N. Boyer, and D.T. Fontaine. 1999. Phosphorus and nitrogen inputs to Florida Bay: The importance of the Everglades watershed. Estuaries 22:398-416.

Rudnick, D., C. Madden, S. Kelly, R. Bennett, K, Cunniff. 2006. Report on algae blooms in Eastern Florida Bay and Southern Biscayne Bay. South Florida Water Management District. 27p.

Savoye, N., A. Aminot, P. Treguer, M. Fontugne, N. Naulet, R. Kerouel. 2003. Dynamics of particulate organic matter $\delta^{15} \mathrm{~N}$ and $\delta^{13} \mathrm{C}$ during spring phytoplankton blooms in a macrotidal ecosystem Bay of Seine, France). Marine Ecology Progress Series 255:27-41.

Teranes, J.L., and S. Bernasconi. 2000. The record of nitrate utilization and productivity limitation provided by $\delta^{15} \mathrm{~N}$ values in lake organic matter - A study of sediment trap and core sediments from Baldeggersee, Switzerland. Limnology and Oceanography 45:801-813. 
APPENDICES 
Appendix 1: Water Quality Data* for POM Time-series Sites

\begin{tabular}{|c|c|c|c|c|c|c|c|}
\hline Station & Date & $\begin{array}{l}\mathrm{NO}_{3}^{-} \\
(\mu \mathrm{M})\end{array}$ & $\begin{array}{l}\mathrm{NH}_{4}^{+} \\
(\mu \mathrm{M}) \\
\end{array}$ & $\begin{array}{l}\text { SRP } \\
(\mu \mathrm{M})\end{array}$ & $\begin{array}{c}\text { CHL-A } \\
(\mathrm{mg} / \mathrm{L})\end{array}$ & Salinity & $\begin{array}{c}\text { Temp. } \\
\left({ }^{\circ} \mathrm{C}\right)\end{array}$ \\
\hline \multirow[t]{10}{*}{215} & 2002.65 & 0.028 & 0.128 & 0.022 & 0.044 & 36.48 & 30.49 \\
\hline & 2003.09 & 0.155 & 0.209 & 0.015 & 0.126 & 35.52 & 18.84 \\
\hline & 2003.33 & 0.388 & 0.536 & 0.021 & 0.082 & 35.42 & 26.01 \\
\hline & 2003.60 & 0.054 & 0.190 & 0.029 & 0.033 & 36.20 & 31.13 \\
\hline & 2003.80 & 0.307 & 0.144 & 0.025 & 0.106 & 34.92 & 27.73 \\
\hline & 2004.11 & 0.104 & 0.267 & 0.010 & 0.158 & 36.33 & 22.26 \\
\hline & 2004.43 & 0.043 & 0.164 & 0.031 & 0.082 & 36.83 & 30.54 \\
\hline & 2004.63 & 0.062 & 0.116 & 0.018 & 0.000 & 36.63 & 31.05 \\
\hline & 2004.80 & 0.000 & 0.119 & 0.049 & 0.043 & 36.209 & 26.721 \\
\hline & 2005.09 & 0.000 & 0.864 & 0.039 & 0.157 & 36.738 & 20.645 \\
\hline \multirow[t]{10}{*}{225} & 2002.66 & 0.142 & 0.218 & 0.050 & 0.014 & 36.06 & 29.70 \\
\hline & 2003.09 & 0.049 & 0.149 & 0.051 & 0.200 & 36.32 & 21.85 \\
\hline & 2003.34 & 0.409 & 0.411 & 0.059 & 0.002 & 36.06 & 26.99 \\
\hline & 2003.61 & 0.037 & 0.218 & 0.015 & 0.016 & 35.30 & 30.48 \\
\hline & 2003.80 & 0.374 & 0.179 & 0.053 & 0.106 & 35.82 & 28.24 \\
\hline & 2004.11 & 0.004 & 0.230 & 0.014 & 0.189 & 36.15 & 24.60 \\
\hline & 2004.44 & 0.043 & 0.148 & 0.038 & 0.000 & 36.48 & 28.18 \\
\hline & 2004.65 & 0.137 & 0.458 & 0.010 & 0.000 & 35.45 & 30.30 \\
\hline & 2004.80 & 0.123 & 0.048 & 0.014 & 0.078 & 35.970 & 28.143 \\
\hline & 2005.09 & 0.270 & 0.378 & 0.017 & 0.011 & 36.474 & 23.474 \\
\hline \multirow[t]{10}{*}{243} & 2002.68 & 0.002 & 0.195 & 0.035 & 0.120 & 36.63 & 30.45 \\
\hline & 2003.11 & 0.704 & 1.485 & 0.084 & 0.335 & 35.53 & 23.09 \\
\hline & 2003.38 & 0.093 & 0.182 & 0.094 & 0.269 & 36.47 & 28.31 \\
\hline & 2003.69 & 0.037 & 0.015 & 0.040 & 0.266 & 35.44 & 29.82 \\
\hline & 2003.82 & 0.071 & 0.239 & 0.134 & 0.179 & 35.96 & 27.85 \\
\hline & 2004.13 & 0.155 & 1.567 & 0.035 & 0.408 & 35.90 & 23.04 \\
\hline & 2004.42 & 0.025 & 0.218 & 0.039 & 0.043 & 36.39 & 28.52 \\
\hline & 2004.65 & 0.043 & 1.192 & 0.021 & 0.000 & 35.50 & 30.61 \\
\hline & 2004.84 & 0.187 & 0.263 & 0.038 & 0.000 & 36.251 & 27.971 \\
\hline & 2005.13 & 1.165 & 1.759 & 0.033 & 0.000 & 36.472 & 23.009 \\
\hline \multirow[t]{5}{*}{248} & 2002.68 & 0.102 & 0.190 & 0.024 & 0.161 & 36.20 & 30.22 \\
\hline & 2002.83 & 0.056 & 0.442 & 0.048 & & & \\
\hline & 2003.11 & 0.546 & 1.003 & 0.108 & 0.323 & 35.00 & 22.54 \\
\hline & 2003.39 & 0.116 & 0.341 & 0.038 & 0.113 & 36.58 & 28.83 \\
\hline & 2003.63 & 0.104 & 0.111 & 0.025 & 0.030 & 35.28 & 30.29 \\
\hline
\end{tabular}




\begin{tabular}{|c|c|c|c|c|c|c|c|}
\hline Station & Date & $\begin{array}{l}\mathrm{NO}_{3}^{-} \\
(\mu \mathrm{M})\end{array}$ & $\begin{array}{l}\mathrm{NH}_{4}^{+} \\
(\mu \mathrm{M})\end{array}$ & $\begin{array}{l}\text { SRP } \\
(\mu \mathrm{M})\end{array}$ & $\begin{array}{c}\text { CHL-A } \\
(\mathrm{mg} / \mathrm{L})\end{array}$ & Salinity & $\begin{array}{c}\text { Temp. } \\
\left({ }^{\circ} \mathrm{C}\right)\end{array}$ \\
\hline 248 & 2004.25 & 0.314 & 0.200 & 0.002 & 0.023 & 36.38 & 24.43 \\
\hline \multirow{4}{*}{ Cont. } & 2004.42 & 0.052 & 0.306 & 0.029 & 0.039 & 36.50 & 28.43 \\
\hline & 2004.65 & 0.082 & 0.317 & 0.020 & 0.098 & 35.51 & 30.71 \\
\hline & 2004.84 & 0.016 & 0.041 & 0.023 & 0.082 & 36.279 & 27.386 \\
\hline & 2005.13 & 0.442 & 1.395 & 0.034 & 0.035 & 36.624 & 22.225 \\
\hline \multirow[t]{9}{*}{255} & 2002.69 & 0.191 & 0.666 & 0.039 & 0.370 & 36.35 & 29.62 \\
\hline & 2003.17 & 0.311 & 0.400 & 0.059 & 0.238 & 35.43 & 26.79 \\
\hline & 2003.42 & 0.262 & 0.295 & 0.074 & 0.186 & 36.47 & 30.02 \\
\hline & 2003.75 & 0.089 & 0.295 & 0.017 & 0.134 & 35.76 & 29.71 \\
\hline & 2003.86 & 0.682 & 0.141 & 0.014 & 0.321 & 34.85 & 26.28 \\
\hline & 2004.25 & 0.090 & 0.611 & 0.018 & 0.110 & 36.45 & 24.20 \\
\hline & 2004.40 & 0.000 & 0.165 & 0.015 & 0.000 & 36.77 & 27.64 \\
\hline & 2004.82 & 0.047 & 0.067 & 0.043 & 0.094 & 36.103 & 27.463 \\
\hline & 2005.07 & 0.000 & 0.740 & 0.075 & 0.000 & 36.462 & 22.756 \\
\hline \multirow[t]{10}{*}{284} & 2002.69 & 0.031 & 0.199 & 0.018 & 0.435 & 37.09 & 27.83 \\
\hline & 2002.85 & 0.058 & 0.282 & 0.000 & 0.264 & 38.32 & 25.96 \\
\hline & 2003.17 & 0.096 & 0.238 & 0.030 & 0.255 & 34.56 & 27.42 \\
\hline & 2003.42 & 0.146 & 0.285 & 0.025 & 0.096 & 35.39 & 29.97 \\
\hline & 2003.75 & 0.195 & 0.111 & 0.048 & 0.273 & 36.16 & 29.68 \\
\hline & 2003.86 & 0.000 & 0.279 & 0.084 & 0.359 & 36.35 & 26.42 \\
\hline & 2004.21 & 0.007 & 0.202 & 0.010 & 0.000 & 34.90 & 24.31 \\
\hline & 2004.36 & 0.041 & 0.265 & 0.022 & 0.000 & 36.47 & 26.07 \\
\hline & 2004.59 & 0.031 & 0.170 & 0.037 & 0.133 & 35.62 & 29.92 \\
\hline & 2005.07 & 0.399 & 0.580 & 0.014 & 1.757 & 35.424 & 18.125 \\
\hline \multirow[t]{10}{*}{287} & 2002.69 & 0.035 & 0.320 & 0.011 & 0.620 & 36.45 & 27.90 \\
\hline & 2002.85 & 0.061 & 0.298 & 0.002 & 0.220 & 38.36 & 26.30 \\
\hline & 2003.17 & 0.093 & 0.324 & 0.073 & 0.191 & 34.70 & 27.55 \\
\hline & 2003.42 & 0.260 & 0.377 & 0.064 & 0.137 & 35.59 & 29.97 \\
\hline & 2003.75 & 0.081 & 0.070 & 0.040 & 0.505 & 36.80 & 29.65 \\
\hline & 2003.86 & 0.019 & 0.135 & 0.037 & 0.151 & 36.94 & 26.24 \\
\hline & 2004.21 & 0.018 & 0.136 & 0.002 & 0.134 & 34.93 & 24.11 \\
\hline & 2004.36 & 0.030 & 0.500 & 0.023 & 0.000 & 36.26 & 25.75 \\
\hline & 2004.59 & 0.142 & 0.147 & 0.025 & 0.453 & 36.45 & 30.04 \\
\hline & 2005.07 & 0.010 & 0.250 & 0.022 & 0.979 & 35.160 & 17.835 \\
\hline
\end{tabular}

$\begin{array}{llllllll}\text { BA } & 2002.79 & 0.165 & 2.520 & 0.019 & 0.491 & 33.61 & 29.99\end{array}$ 


\begin{tabular}{|c|c|c|c|c|c|c|c|}
\hline Station & Date & $\begin{array}{l}\mathrm{NO}_{3}^{-} \\
(\mu \mathrm{M})\end{array}$ & $\begin{array}{l}\mathrm{NH}_{4}^{+} \\
(\mu \mathrm{M})\end{array}$ & $\begin{array}{l}\text { SRP } \\
(\mu \mathrm{M})\end{array}$ & $\begin{array}{c}\text { CHL-A } \\
(\mathrm{mg} / \mathrm{L})\end{array}$ & Salinity & $\begin{array}{c}\text { Temp. } \\
\left({ }^{\circ} \mathrm{C}\right)\end{array}$ \\
\hline BA & 2003.07 & 0.129 & 1.337 & 0.049 & 0.435 & 34.62 & 15.11 \\
\hline \multirow[t]{9}{*}{ Cont. } & 2003.19 & 0.087 & 2.773 & 0.072 & 0.705 & 35.74 & 28.18 \\
\hline & 2003.44 & 1.780 & 2.002 & 0.088 & 1.438 & 34.64 & 29.85 \\
\hline & 2003.69 & 0.134 & 2.963 & 0.013 & 1.233 & 35.71 & 31.81 \\
\hline & 2004.05 & 0.194 & 2.208 & 0.008 & 0.285 & 28.46 & 20.32 \\
\hline & 2004.22 & 0.164 & 0.700 & 0.029 & 0.914 & 33.42 & 23.16 \\
\hline & 2004.49 & 0.596 & 0.809 & 0.041 & 0.937 & 43.95 & 31.80 \\
\hline & 2004.74 & 0.077 & 2.771 & 0.008 & 0.459 & 38.39 & 30.08 \\
\hline & 2004.82 & 0.298 & 4.216 & 0.025 & 0.700 & 41.71 & 26.12 \\
\hline & 2005.06 & 0.178 & 1.404 & 0.054 & 0.459 & 41.68 & 16.93 \\
\hline \multirow[t]{10}{*}{ DK } & 2002.71 & 0.888 & 1.266 & 0.133 & 0.408 & 24.36 & 30.07 \\
\hline & 2003.07 & 3.043 & 5.430 & 0.039 & 0.156 & 28.07 & 14.57 \\
\hline & 2003.19 & 5.200 & 7.587 & 0.063 & 0.306 & 29.99 & 28.05 \\
\hline & 2003.44 & 1.108 & 4.145 & 0.038 & 0.337 & 31.11 & 29.35 \\
\hline & 2003.68 & 1.612 & 4.261 & 0.281 & 0.521 & 16.76 & 29.85 \\
\hline & 2004.06 & 1.243 & 4.435 & 0.012 & 0.149 & 25.71 & 19.17 \\
\hline & 2004.24 & 0.900 & 1.768 & 0.016 & 0.170 & 30.24 & 23.66 \\
\hline & 2004.49 & 0.589 & 0.955 & 0.045 & 0.218 & 38.57 & 30.11 \\
\hline & 2004.74 & 1.687 & 16.967 & 0.028 & 0.502 & 38.60 & 29.16 \\
\hline & 2005.07 & 2.508 & 8.415 & 0.030 & 0.328 & 38.33 & 15.76 \\
\hline \multirow[t]{10}{*}{ SP } & 2002.71 & 0.064 & 0.234 & 0.043 & 1.081 & 30.13 & 3.38 \\
\hline & 2003.07 & 0.294 & 0.220 & 0.030 & 1.299 & 14.31 & 9.37 \\
\hline & 2003.19 & 0.222 & 0.318 & 0.096 & 0.476 & 27.91 & 1.39 \\
\hline & 2003.44 & 0.416 & 0.468 & 0.061 & 0.413 & 30.13 & 1.41 \\
\hline & 2003.69 & 0.063 & 0.218 & 0.031 & 0.708 & 30.25 & 2.80 \\
\hline & 2004.05 & 0.098 & 0.388 & 0.017 & 0.410 & 19.65 & 1.87 \\
\hline & 2004.22 & 0.398 & 0.177 & 0.021 & 0.486 & 23.37 & 3.39 \\
\hline & 2004.49 & 0.680 & 0.204 & 0.040 & 0.463 & 31.01 & 1.96 \\
\hline & 2004.74 & 0.059 & 0.127 & 0.014 & 0.740 & 28.56 & 2.07 \\
\hline & 2005.06 & 0.054 & 1.128 & 0.072 & 1.515 & 16.79 & 9.675 \\
\hline
\end{tabular}

* Data were provided by the SERC-FIU Water Quality Monitoring Network which is supported by SFWMD/SERC Cooperative Agreement \#4600000352 as well as EPA Agreement \#X7-96410603-3. 
Appendix 2: Element and Stable Isotope Data from Three POM Size Fractions

\begin{tabular}{|c|c|c|c|c|c|c|c|c|c|c|c|c|c|c|c|c|}
\hline \multicolumn{2}{|c|}{ Size Fraction } & \multicolumn{5}{|c|}{$0.1-50 \mu \mathrm{M}$} & \multicolumn{5}{|c|}{$50-150 \mu \mathrm{M}$} & \multicolumn{5}{|c|}{$>150 \mu \mathrm{M}$} \\
\hline Site & Quarter & $\% \mathrm{~N}$ & $\% \mathrm{C}$ & $\begin{array}{c}\delta^{15} \mathrm{~N} \\
(\% \mathrm{AIR})\end{array}$ & $\begin{array}{c}\delta^{13} \mathrm{C} \\
\text { (\% PDB) }\end{array}$ & $\mathrm{C}: \mathrm{N}$ & $\% \mathrm{~N}$ & $\% \mathrm{C}$ & $\begin{array}{c}\delta^{15} \mathrm{~N} \\
(\% \mathrm{AIR})\end{array}$ & $\begin{array}{c}\delta^{13} \mathrm{C} \\
\text { (\% PDB) }\end{array}$ & $\mathrm{C}: \mathrm{N}$ & $\% \mathrm{~N}$ & $\% \mathrm{C}$ & $\begin{array}{c}\begin{array}{c}\delta^{15} \mathrm{~N} \\
(\% \mathrm{AIR})\end{array} \\
\end{array}$ & $\begin{array}{c}\delta^{13} \mathrm{C} \\
\text { (\% PDB) }\end{array}$ & $\mathrm{C}: \mathrm{N}$ \\
\hline \multirow[t]{10}{*}{215} & Sept. 2002 & n.s & & & & & & 25.04 & & -24.70 & & 2.520 & & 6.45 & & \\
\hline & Jan. 2003 & 0.017 & 0.110 & 7.68 & -24.29 & 7.4 & 1.03 & 16.25 & 4.35 & -23.60 & 18.4 & 4.255 & 31.234 & 4.70 & -22.69 & 8.6 \\
\hline & Mar. 2003 & 0.012 & 0.070 & 3.56 & -25.06 & 6.9 & 1.80 & 7.79 & 4.20 & -21.29 & 5.1 & 7.587 & 33.460 & 5.85 & -23.77 & 5.1 \\
\hline & Jun. 2003 & 0.010 & 0.250 & 2.48 & -23.36 & 28.1 & 1.61 & 22.88 & 3.02 & -21.39 & 16.6 & 1.417 & 24.031 & 3.86 & -23.76 & 19.8 \\
\hline & Sept. 2003 & 0.014 & 0.450 & 2.99 & -23.91 & 37.2 & 1.73 & 18.26 & 3.39 & -18.91 & 12.3 & 3.598 & 3.280 & 3.89 & -23.43 & 1.1 \\
\hline & Jan. 2004 & 0.013 & 0.100 & 5.71 & -24.46 & 9.1 & 1.44 & 19.58 & 3.66 & -17.93 & 15.8 & 6.483 & 8.370 & 4.56 & -23.89 & 1.5 \\
\hline & Mar. 2004 & 0.008 & 0.050 & 4.25 & -22.06 & 7.4 & 0.39 & 4.22 & 3.06 & -16.37 & 12.6 & 3.942 & 31.790 & 3.69 & -17.07 & 9.4 \\
\hline & Jun. 2004 & 0.011 & 0.050 & 3.06 & -22.48 & 5.1 & 1.99 & 7.69 & 5.29 & -20.07 & 4.5 & 4.523 & 26.875 & 4.09 & -18.75 & 6.9 \\
\hline & Sept. 2004 & 0.011 & 0.050 & 3.14 & -21.81 & 5.5 & 1.48 & & 3.50 & & & 5.871 & 4.250 & 4.50 & -22.10 & 0.8 \\
\hline & Jan. 2005 & 0.010 & 0.070 & 3.08 & -23.39 & 8.2 & & & 3.24 & & & & 15.490 & 2.70 & -19.40 & \\
\hline \multirow[t]{10}{*}{225} & Sept. 2002 & n.s & & & & & 1.57 & 41.34 & 4.07 & -24.96 & 30.7 & 2.067 & 37.228 & 3.68 & -18.82 & 21.0 \\
\hline & Jan. 2003 & 0.011 & 0.060 & 5.03 & -24.99 & 6.6 & 1.51 & 16.87 & 4.01 & -19.67 & 13.0 & 6.721 & 11.700 & 4.58 & -23.67 & 2.0 \\
\hline & Mar. 2003 & 0.026 & 0.060 & 3.89 & -22.39 & 2.7 & 2.96 & 17.42 & 4.07 & -19.81 & 6.9 & 7.747 & 7.380 & 7.44 & -19.45 & 1.1 \\
\hline & Jun. 2003 & 0.023 & 0.150 & 6.06 & -23.92 & 7.8 & 2.73 & 18.49 & 3.61 & -20.11 & 7.9 & 7.601 & 27.480 & 4.78 & -20.63 & 4.2 \\
\hline & Sept. 2003 & 0.011 & 0.080 & 1.90 & -25.70 & 8.4 & 0.86 & 16.53 & 2.27 & -14.78 & 22.6 & 2.742 & 35.035 & 2.35 & -13.16 & 14.9 \\
\hline & Jan. 2004 & 0.010 & 0.050 & 4.32 & -23.39 & 5.6 & 0.95 & 9.86 & 3.37 & -21.54 & 12.1 & 7.413 & 32.610 & 5.02 & -23.60 & 5.1 \\
\hline & Mar. 2004 & 0.010 & 0.060 & 2.75 & -22.04 & 7.3 & 0.70 & 16.09 & 2.75 & -15.69 & 26.7 & 4.463 & 41.100 & 3.78 & -16.85 & 10.7 \\
\hline & Jun. 2004 & 0.012 & 0.060 & 3.79 & -21.58 & 5.6 & 1.12 & & 1.89 & & & 2.766 & 42.760 & 2.23 & -17.14 & 18.0 \\
\hline & Sept. 2004 & 0.012 & 0.080 & 3.13 & -23.64 & 7.5 & 1.30 & 22.72 & 3.25 & -18.57 & 20.4 & 4.240 & 25.530 & 4.36 & -15.66 & 7.0 \\
\hline & Jan. 2005 & 0.010 & 0.070 & 3.30 & -24.05 & 8.2 & & & 2.45 & & & & 22.090 & 3.38 & -13.12 & \\
\hline \multirow[t]{8}{*}{243} & Sept. 2002 & n.s & & & & & 1.55 & 24.33 & 3.01 & -19.13 & 18.3 & 5.713 & 43.706 & 3.89 & -19.92 & 8.9 \\
\hline & Jan. 2003 & 0.006 & 0.110 & 6.41 & -24.3 & 20.3 & 2.20 & & 5.56 & & & 4.821 & 32.122 & 4.71 & -21.01 & 7.8 \\
\hline & Mar. 2003 & 0.016 & 0.060 & 2.62 & -23.8 & 4.5 & 2.07 & 2.80 & 4.45 & -21.62 & 1.6 & 6.894 & 15.570 & 6.55 & -24.06 & 2.6 \\
\hline & Jun. 2003 & 0.017 & 0.090 & 3.33 & -22.5 & 6.1 & 3.48 & 5.40 & 3.92 & -19.97 & 1.8 & 2.892 & 42.403 & 4.33 & -22.52 & 17.1 \\
\hline & Sept. 2003 & 0.017 & 0.310 & 2.64 & -23.6 & 20.7 & 2.28 & 10.51 & 3.71 & -24.60 & 5.4 & 3.747 & 30.395 & 4.20 & -21.73 & 9.5 \\
\hline & Jan. 2004 & 0.010 & 0.380 & 1.98 & -25.5 & 45.8 & 0.40 & 9.89 & 2.91 & -16.91 & 28.6 & 2.630 & 22.380 & 3.38 & -16.74 & 9.9 \\
\hline & Mar. 2004 & 0.011 & 0.060 & 2.67 & -23.2 & 6.4 & 1.75 & 11.68 & 3.44 & -23.37 & 7.8 & 3.431 & 13.420 & 3.45 & -22.73 & 4.6 \\
\hline & Jun. 2004 & 0.010 & 0.050 & 2.31 & -22.5 & 5.9 & 1.48 & 7.41 & 2.75 & -19.55 & 5.8 & 3.965 & 29.155 & 1.35 & -19.84 & 8.6 \\
\hline
\end{tabular}




\begin{tabular}{|c|c|c|c|c|c|c|c|c|c|c|c|c|c|c|c|c|}
\hline Site & Quarter & $\% \mathrm{~N}$ & $\% \mathrm{C}$ & $\begin{array}{c}\delta^{15} \mathrm{~N} \\
(\% 0 \mathrm{AIR}) \\
\end{array}$ & $\begin{array}{c}\delta^{13} \mathrm{C} \\
(\% 0 \text { PDB) }\end{array}$ & $\mathrm{C}: \mathrm{N}$ & $\% \mathrm{~N}$ & $\% \mathrm{C}$ & $\begin{array}{c}\delta^{15} \mathrm{~N} \\
(\% 0 \mathrm{AIR}) \\
\end{array}$ & $\begin{array}{c}\delta^{13} \mathrm{C} \\
(\% \text { PDB) }\end{array}$ & $\mathrm{C}: \mathrm{N}$ & $\% \mathrm{~N}$ & $\% \mathrm{C}$ & $\begin{array}{c}\begin{array}{c}\delta^{15} \mathrm{~N} \\
(\% \mathrm{AIR})\end{array} \\
\end{array}$ & $\begin{array}{c}\begin{array}{c}\delta^{13} \mathrm{C} \\
(\% \mathrm{PDB})\end{array} \\
\end{array}$ & $\mathrm{C}: \mathrm{N}$ \\
\hline & Sept. 2004 & 0.018 & 0.080 & 3.41 & -21.6 & 5.3 & 3.71 & 18.24 & 3.97 & -18.89 & 5.7 & 6.165 & 39.260 & 5.05 & -22.50 & 7.4 \\
\hline & Jan. 2005 & 0.010 & 0.080 & 3.11 & -23.5 & 9.3 & & & 2.58 & & & & 13.750 & 4.70 & -17.98 & \\
\hline \multirow[t]{10}{*}{248} & Sept. 2002 & n.s & & & & & 2.15 & 24.02 & 3.57 & -18.40 & 13.0 & 1.574 & 23.237 & 4.78 & -15.75 & 17.2 \\
\hline & Jan. 2003 & 0.011 & 0.080 & 2.01 & -23.9 & 8.3 & 1.25 & 7.31 & 3.64 & -19.71 & 6.8 & 6.512 & 31.557 & 4.34 & -19.53 & 5.7 \\
\hline & Mar. 2003 & 0.017 & 0.100 & 2.68 & -24.1 & 6.9 & 2.55 & 9.38 & 4.80 & -24.34 & 4.3 & 4.830 & 25.220 & 4.81 & -14.37 & 6.1 \\
\hline & Jun. 2003 & 0.011 & 0.090 & 1.54 & -23.3 & 9.2 & 4.03 & 16.46 & 4.13 & -20.28 & 4.8 & 1.858 & 23.660 & 3.60 & -20.22 & 14.9 \\
\hline & Sept. 2003 & 0.011 & 0.170 & 1.55 & -23.5 & 17.5 & 2.37 & 27.18 & 3.02 & -18.62 & 13.4 & 2.973 & 26.724 & 4.11 & -18.70 & 10.5 \\
\hline & Jan. 2004 & 0.024 & 0.060 & 2.26 & -23 & 2.9 & 1.06 & 24.32 & 2.28 & -13.10 & 26.8 & 3.737 & 38.500 & 4.10 & -15.61 & 12.0 \\
\hline & Mar. 2004 & 0.016 & 0.070 & 2.89 & -22 & 5.1 & 1.84 & 13.37 & 3.58 & -16.94 & 8.5 & 3.370 & 22.540 & 3.86 & -21.21 & 7.8 \\
\hline & Jun. 2004 & 0.015 & 0.080 & 1.46 & -20.6 & 6.4 & 3.67 & 7.58 & 3.35 & -18.36 & 2.4 & 4.142 & 28.510 & 5.07 & -17.54 & 8.0 \\
\hline & Sept. 2004 & 0.015 & 0.090 & 2.74 & -22.3 & 7.2 & 2.42 & 13.80 & 3.58 & -15.27 & 6.6 & 4.296 & 39.260 & 4.52 & -22.50 & 10.7 \\
\hline & Jan. 2005 & 0.020 & 0.120 & 3.77 & -22.3 & 7.0 & & & 2.94 & & & & 5.670 & 4.59 & -23.70 & \\
\hline \multirow[t]{10}{*}{255} & Sept. 2002 & n.s & & & & & & & & & & & & & & \\
\hline & Jan. 2003 & 0.009 & 0.050 & 2.29 & -23.9 & 6.2 & 2.26 & 10.85 & 3.98 & -24.90 & 5.6 & 4.434 & 11.960 & 4.73 & -23.87 & 3.1 \\
\hline & Mar. 2003 & n.s & & & & & 2.37 & 5.99 & 5.03 & -19.96 & 2.9 & 2.221 & 28.035 & 3.28 & & 14.7 \\
\hline & Jun. 2003 & 0.014 & 0.210 & 1.64 & -23 & 17.3 & 4.01 & 20.57 & 4.02 & -19.43 & 6.0 & 3.565 & 21.830 & 4.65 & -21.70 & 7.1 \\
\hline & Sept. 2003 & 0.014 & 0.060 & 1.57 & -22.3 & 5.0 & 2.31 & 10.95 & 3.46 & -18.24 & 5.5 & 1.170 & 5.080 & 5.03 & -19.91 & 5.1 \\
\hline & Jan. 2004 & 0.016 & 0.050 & 2.89 & -24.6 & 3.6 & 2.72 & 11.31 & 3.23 & -17.64 & 4.8 & 1.171 & 12.730 & 2.67 & -13.04 & 12.7 \\
\hline & Mar. 2004 & 0.017 & 0.060 & 3.57 & -21.7 & 4.2 & 0.65 & 15.43 & 3.18 & -15.61 & 27.6 & 3.520 & 20.400 & 4.01 & -14.29 & 6.8 \\
\hline & Jun. 2004 & 0.023 & 0.110 & 2.96 & -20.3 & 5.5 & 2.56 & 16.07 & 3.81 & -20.26 & 7.3 & 3.284 & 18.280 & 4.48 & -19.74 & 6.5 \\
\hline & Sept. 2004 & 0.034 & 0.130 & 2.50 & -19.3 & 4.5 & 4.00 & 16.63 & 3.97 & -17.95 & 4.8 & 5.161 & 46.030 & 5.72 & -26.80 & 10.4 \\
\hline & Jan. 2005 & 0.020 & 0.105 & 1.44 & -21.39 & 6.1 & & & 3.74 & & & & 9.550 & 5.47 & -20.88 & \\
\hline \multirow[t]{10}{*}{284} & Sept. 2002 & n.s & & & & & 2.46 & 8.56 & 4.28 & -18.43 & 4.1 & 1.880 & 36.393 & 3.19 & -18.97 & 22.6 \\
\hline & Jan. 2003 & 0.010 & 0.080 & 3.02 & -23.2 & 9.4 & 1.46 & 14.18 & 3.40 & -15.01 & 11.4 & 3.361 & 25.297 & 4.95 & -20.06 & 8.8 \\
\hline & Mar. 2003 & 0.013 & 0.090 & 4.30 & -21.5 & 8.1 & 1.47 & 16.79 & 3.83 & -14.50 & 13.4 & 2.373 & 24.470 & 3.82 & -11.97 & 12.0 \\
\hline & Jun. 2003 & 0.013 & 0.080 & 3.28 & -20.7 & 7.4 & 2.01 & 9.61 & 3.86 & -14.90 & 5.6 & 1.339 & 19.540 & 1.99 & -12.25 & 17.0 \\
\hline & Sept. 2003 & 0.028 & 0.090 & 3.47 & -19.77 & 3.7 & 2.78 & 18.61 & 3.48 & -14.91 & 7.8 & 1.088 & 17.670 & 2.64 & -10.62 & 18.9 \\
\hline & Jan. 2004 & 0.026 & 0.080 & 1.66 & -23.9 & 3.6 & 1.52 & 7.92 & 4.42 & -20.06 & 6.1 & 2.192 & 25.310 & 3.73 & -15.91 & 13.5 \\
\hline & Mar. 2004 & 0.029 & 0.100 & 3.37 & -19.7 & 4.0 & 2.51 & 21.99 & 3.63 & -15.28 & 10.2 & 1.870 & 23.770 & 3.16 & -12.64 & 14.8 \\
\hline & Jun. 2004 & 0.020 & 0.080 & 4.47 & -20.5 & 4.7 & 3.75 & 16.33 & 4.75 & -20.07 & 5.1 & 6.887 & 9.070 & 8.39 & -19.36 & 1.5 \\
\hline & Sept. 2004 & 0.028 & 0.140 & 2.38 & -18.4 & 5.7 & 2.28 & 9.15 & 3.96 & -14.93 & 4.7 & 1.613 & 14.280 & 3.09 & -11.72 & 10.3 \\
\hline & Jan. 2005 & 0.015 & 0.115 & 2.31 & -22.56 & 8.9 & & & 3.92 & & & & 27.690 & 4.07 & -12.72 & \\
\hline
\end{tabular}




\begin{tabular}{|c|c|c|c|c|c|c|c|c|c|c|c|c|c|c|c|c|}
\hline Site & Quarter & $\% \mathrm{~N}$ & $\% \mathrm{C}$ & $\begin{array}{c}\delta^{15} \mathrm{~N} \\
(\% 0 \mathrm{AIR}) \\
\end{array}$ & $\begin{array}{c}\delta^{13} \mathrm{C} \\
\text { (\% PDB) }\end{array}$ & $\mathrm{C}: \mathrm{N}$ & $\% \mathrm{~N}$ & $\% \mathrm{C}$ & $\begin{array}{c}\delta^{15} \mathrm{~N} \\
(\% 0 \mathrm{AIR}) \\
\end{array}$ & $\begin{array}{c}\delta^{13} \mathrm{C} \\
(\% \text { PDB) }\end{array}$ & $\mathrm{C}: \mathrm{N}$ & $\% \mathrm{~N}$ & $\% \mathrm{C}$ & $\begin{array}{c}\begin{array}{c}\delta^{15} \mathrm{~N} \\
(\% \mathrm{AIR})\end{array} \\
\end{array}$ & $\begin{array}{c}\begin{array}{c}\delta^{13} \mathrm{C} \\
(\% \mathrm{PDB})\end{array} \\
\end{array}$ & $\mathrm{C}: \mathrm{N}$ \\
\hline \multirow[t]{10}{*}{287} & Sept. 2002 & n.s & & & & & 1.51 & 9.18 & 4.01 & -17.28 & 7.1 & & & & & \\
\hline & Jan. 2003 & n.s & & & & & 0.88 & 11.29 & 3.39 & -14.90 & 15.0 & 2.415 & 24.310 & 4.19 & -20.31 & 11.7 \\
\hline & Mar. 2003 & 0.012 & 0.120 & 1.09 & -22.1 & 12.0 & 1.75 & 13.33 & 3.93 & -16.05 & 8.9 & 3.711 & 7.170 & 4.97 & -16.63 & 2.3 \\
\hline & Jun. 2003 & 0.017 & 0.100 & 2.10 & -21.9 & 6.9 & 2.06 & 10.46 & 3.87 & -15.43 & 5.9 & 1.240 & 5.490 & 2.49 & -14.33 & 5.2 \\
\hline & Sept. 2003 & 0.02 & 0.15 & 2.3 & -22.9 & 8.8 & 2.02 & 12.26 & 3.83 & -13.76 & 7.1 & 1.464 & 21.360 & 2.26 & -7.40 & 17.0 \\
\hline & Jan. 2004 & 0.037 & 0.260 & 2.52 & -24.2 & 8.3 & 0.70 & 6.16 & 2.78 & -15.40 & 10.2 & 8.156 & 33.026 & 4.54 & -18.47 & 4.7 \\
\hline & Mar. 2004 & 0.025 & 0.070 & 2.05 & -20.2 & 3.3 & 2.50 & 12.76 & 3.49 & -15.82 & 6.0 & 1.446 & 20.250 & 2.22 & -13.73 & 16.3 \\
\hline & Jun. 2004 & 0.034 & 0.170 & 2.94 & -17.8 & 5.9 & 2.93 & 13.20 & 4.38 & -19.96 & 5.3 & 1.695 & 16.380 & 3.81 & -20.65 & 11.3 \\
\hline & Sept. 2004 & 0.017 & 0.090 & 2.27 & -18.4 & 6.1 & 2.70 & 11.92 & 3.81 & -16.06 & 5.2 & 2.873 & 9.250 & 3.66 & -14.75 & 3.8 \\
\hline & Jan. 2005 & 0.020 & 0.115 & 1.94 & -21.2 & 6.7 & & & 3.66 & & & 2.456 & 15.880 & 3.23 & -14.48 & 7.5 \\
\hline \multirow[t]{10}{*}{ SP } & Sept. 2002 & n.s & & & & & 1.50 & 9.96 & 4.65 & -18.27 & 7.7 & 0.856 & 39.620 & 3.58 & -23.59 & 54.0 \\
\hline & Jan. 2003 & 0.025 & 0.060 & 4.60 & -24.5 & 2.8 & 1.33 & 11.09 & 4.94 & -17.11 & 9.7 & 3.945 & 26.850 & 4.65 & -20.48 & 7.9 \\
\hline & Mar. 2003 & & 0.130 & 4.05 & -26 & & 3.28 & 17.38 & 5.81 & -18.88 & 6.2 & 1.757 & 26.400 & 4.48 & -19.15 & 17.5 \\
\hline & Jun. 2003 & 0.017 & 1.070 & 3.51 & -29.6 & 73.3 & 0.54 & 10.84 & 4.38 & -15.76 & 23.5 & 1.033 & 19.590 & 2.80 & -14.94 & 22.1 \\
\hline & Sept. 2003 & 0.026 & 0.480 & 2.44 & -25.7 & 21.8 & 1.23 & 11.62 & 3.43 & -14.29 & 11.0 & 2.119 & 27.860 & 1.97 & -10.79 & 15.3 \\
\hline & Jan. 2004 & 0.038 & 0.210 & 3.21 & -26.1 & 6.5 & 1.27 & 4.00 & 5.17 & -25.58 & 3.7 & 0.892 & 4.310 & 4.19 & -28.95 & 5.6 \\
\hline & Mar. 2004 & 0.060 & 0.280 & 1.57 & -26.3 & 5.5 & 1.97 & 13.97 & 2.13 & -12.91 & 8.3 & 2.681 & 30.910 & 3.54 & -17.75 & 13.5 \\
\hline & Jun. 2004 & 0.030 & 0.150 & 3.06 & -20.4 & 5.8 & 1.96 & 14.91 & 4.99 & -19.99 & 8.9 & 4.302 & 10.730 & 5.09 & -17.58 & 2.9 \\
\hline & Sept. 2004 & 0.028 & 0.090 & 2.78 & -19.6 & 3.7 & 0.95 & 11.22 & 3.93 & -15.65 & 13.8 & 3.363 & 22.000 & 3.57 & -21.98 & 7.6 \\
\hline & Jan. 2005 & & 0.410 & 4.60 & -18.3 & & & & 5.02 & & & & & & & \\
\hline \multirow[t]{10}{*}{ BA } & Sept. 2002 & n.s & & & & & 2.79 & & 4.20 & & & 1.664 & 33.785 & 5.25 & -25.41 & 23.7 \\
\hline & Jan. 2003 & 0.018 & 0.190 & 3.01 & -22.1 & 12.3 & 1.53 & 25.26 & 5.07 & -19.18 & 19.2 & 1.087 & 26.035 & 3.87 & -25.02 & 27.9 \\
\hline & Mar. 2003 & n.s & & & & & 0.78 & 7.86 & 4.92 & -15.51 & 11.7 & 0.860 & 15.166 & 4.12 & -16.00 & 20.6 \\
\hline & Jun. 2003 & 0.033 & 0.130 & 2.71 & -17.9 & 4.5 & 1.52 & 31.85 & 4.02 & -14.84 & 24.5 & 4.223 & 7.245 & 5.58 & -12.98 & 2.0 \\
\hline & Sept. 2003 & 0.091 & 0.250 & 2.99 & -13.4 & 3.2 & 2.41 & 29.20 & 2.65 & -16.92 & 14.1 & 0.705 & 11.430 & 3.80 & -16.93 & 18.9 \\
\hline & Jan. 2004 & & & 2.70 & -18 & & 0.53 & 7.53 & 4.22 & -13.87 & 16.7 & 0.911 & 10.654 & 4.10 & -16.40 & 13.6 \\
\hline & Mar. 2004 & 0.080 & 0.200 & 2.42 & -15 & 2.9 & 1.76 & 15.32 & 4.29 & -14.31 & 10.1 & 1.354 & 29.970 & 4.05 & -18.65 & 25.8 \\
\hline & Jun. 2004 & 0.118 & & 2.23 & -14 & & 2.49 & 48.14 & 3.88 & -13.80 & 22.6 & 1.766 & 7.340 & 3.76 & -17.90 & 4.8 \\
\hline & Sept. 2004 & 0.086 & 0.460 & 3.28 & -11.4 & 6.2 & 0.59 & 7.65 & 4.44 & -13.46 & 15.1 & 2.104 & 31.349 & 4.83 & -15.42 & 17.4 \\
\hline & Jan. 2005 & 0.160 & & 3.26 & -11.7 & & & & 5.08 & & & & & & & \\
\hline \multirow[t]{2}{*}{ DK } & Sept. 2002 & n.s & & & & & 2.35 & 20.02 & 4.84 & -18.92 & 9.9 & 0.253 & 28.237 & 8.51 & -26.25 & 130.2 \\
\hline & Jan. 2003 & 0.015 & 0.160 & 4.09 & -19.6 & 12.3 & 0.62 & 12.30 & 6.18 & -19.80 & 23.2 & 2.264 & 21.488 & 6.33 & -18.78 & 11.1 \\
\hline
\end{tabular}




\begin{tabular}{|c|c|c|c|c|c|c|c|c|c|c|c|c|c|c|c|c|}
\hline Site & Quarter & $\% \mathrm{~N}$ & $\% \mathrm{C}$ & $\begin{array}{c}\delta^{15} \mathrm{~N} \\
(\% \mathrm{AIR})\end{array}$ & $\begin{array}{c}\delta^{13} \mathrm{C} \\
(\% 0 \text { PDB) }\end{array}$ & $\mathrm{C}: \mathrm{N}$ & $\% \mathrm{~N}$ & $\% \mathrm{C}$ & $\begin{array}{c}\delta^{15} \mathrm{~N} \\
(\% \mathrm{AIR})\end{array}$ & $\begin{array}{c}\delta^{13} \mathrm{C} \\
(\% \text { PDB) }\end{array}$ & $\mathrm{C}: \mathrm{N}$ & $\% \mathrm{~N}$ & $\% \mathrm{C}$ & $\begin{array}{c}\begin{array}{c}\delta^{15} \mathrm{~N} \\
(\% \mathrm{AIR})\end{array} \\
\end{array}$ & $\begin{array}{c}\delta^{13} \mathrm{C} \\
\text { (\% PDB) }\end{array}$ & $\mathrm{C}: \mathrm{N}$ \\
\hline & Mar. 2003 & 0.040 & & 4.85 & -25 & & 0.29 & 8.51 & 6.08 & -17.80 & 34.3 & 1.685 & 11.120 & 4.68 & -20.85 & 7.7 \\
\hline & Jun. 2003 & 0.019 & 0.150 & 3.56 & -18.8 & 9.4 & 1.19 & 30.59 & 4.68 & -16.69 & 30.0 & 2.135 & 30.859 & 5.44 & -20.47 & 16.9 \\
\hline & Sept. 2003 & 0.049 & 0.800 & 4.07 & -24.8 & 19.2 & 2.03 & 32.10 & 2.31 & -16.99 & 18.5 & & & & & \\
\hline & Jan. 2004 & 0.027 & 0.200 & 4.13 & -19.4 & 8.8 & 0.88 & 10.57 & 6.00 & -19.97 & 14.0 & 2.939 & 23.991 & 7.72 & -16.76 & 9.5 \\
\hline & Mar. 2004 & 0.063 & 0.760 & 4.51 & -26.7 & 14.1 & 1.76 & 18.60 & 6.34 & -15.23 & 12.3 & 2.243 & 29.100 & 6.29 & -16.17 & 15.1 \\
\hline & Jun. 2004 & 0.034 & 0.230 & 4.73 & -18.3 & 7.8 & 1.35 & 17.76 & 6.75 & -19.48 & 15.3 & 1.321 & 22.061 & 3.91 & -23.35 & 19.5 \\
\hline & Sept. 2004 & 0.073 & 0.340 & 4.26 & -15.0 & 5.4 & 0.51 & 6.93 & 5.70 & -18.63 & 16.0 & 0.944 & 9.860 & 5.63 & -21.98 & 12.2 \\
\hline & Jan. 2005 & & 0.770 & 4.65 & -13.0 & & & & 5.97 & & & & & & & \\
\hline
\end{tabular}

n.s - 0.1-50 $\mu \mathrm{M}$ size class was not sampled in Sept. 2002

* data gaps are due to insufficient sample for analysis 
Appendix 3: Species assemblages in the $50-150 \mu \mathrm{m}$ size fraction of POM

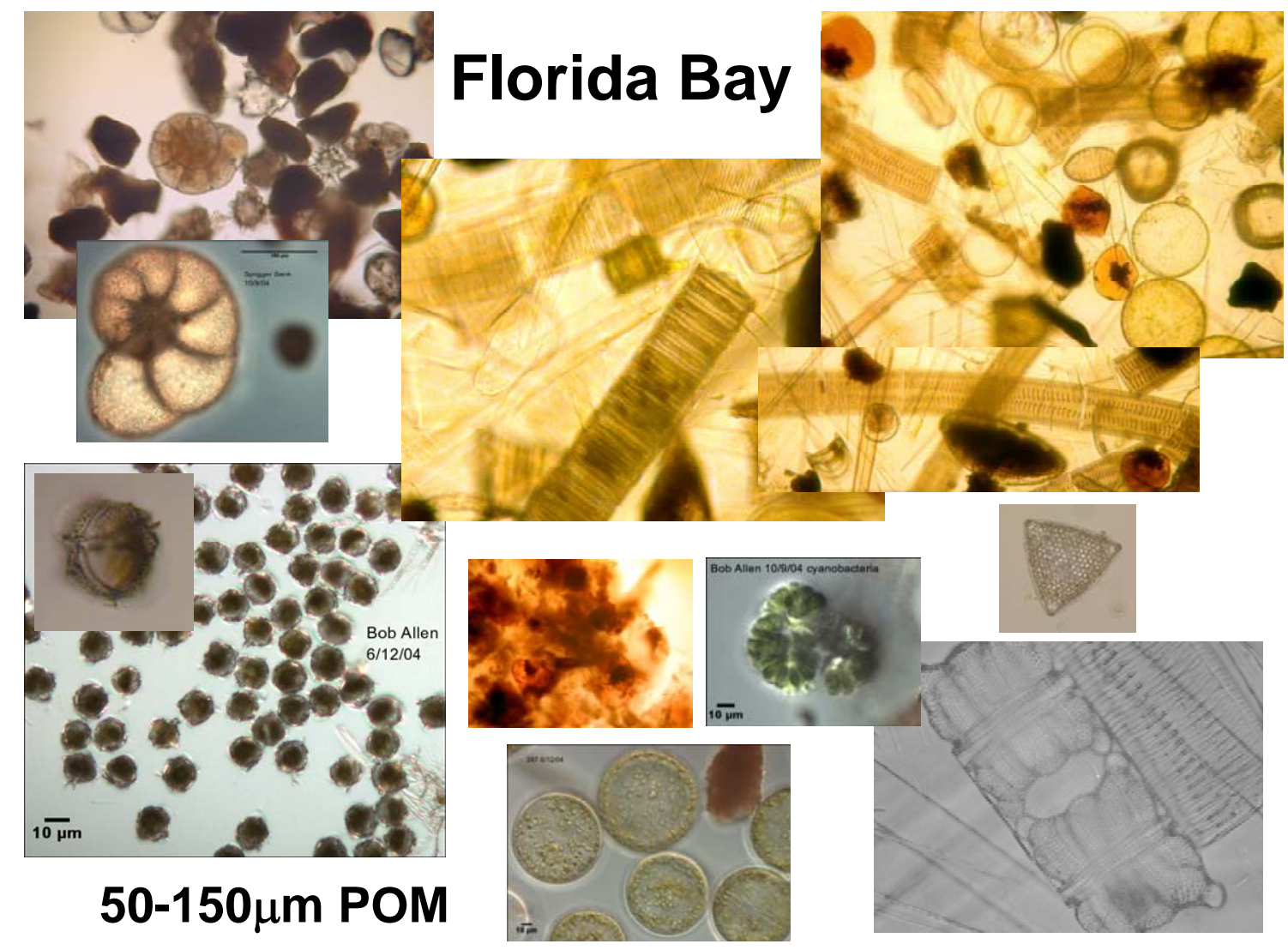

Florida Bay assemblages were dominated by diverse group of diatom species, with lower abundances of benthic foraminifera, green microalgae, sediment particles, and organic detritus particles. Summer samplings showed a monospecific dinoflagellate bloom at interior/NE Florida Bay sites. 

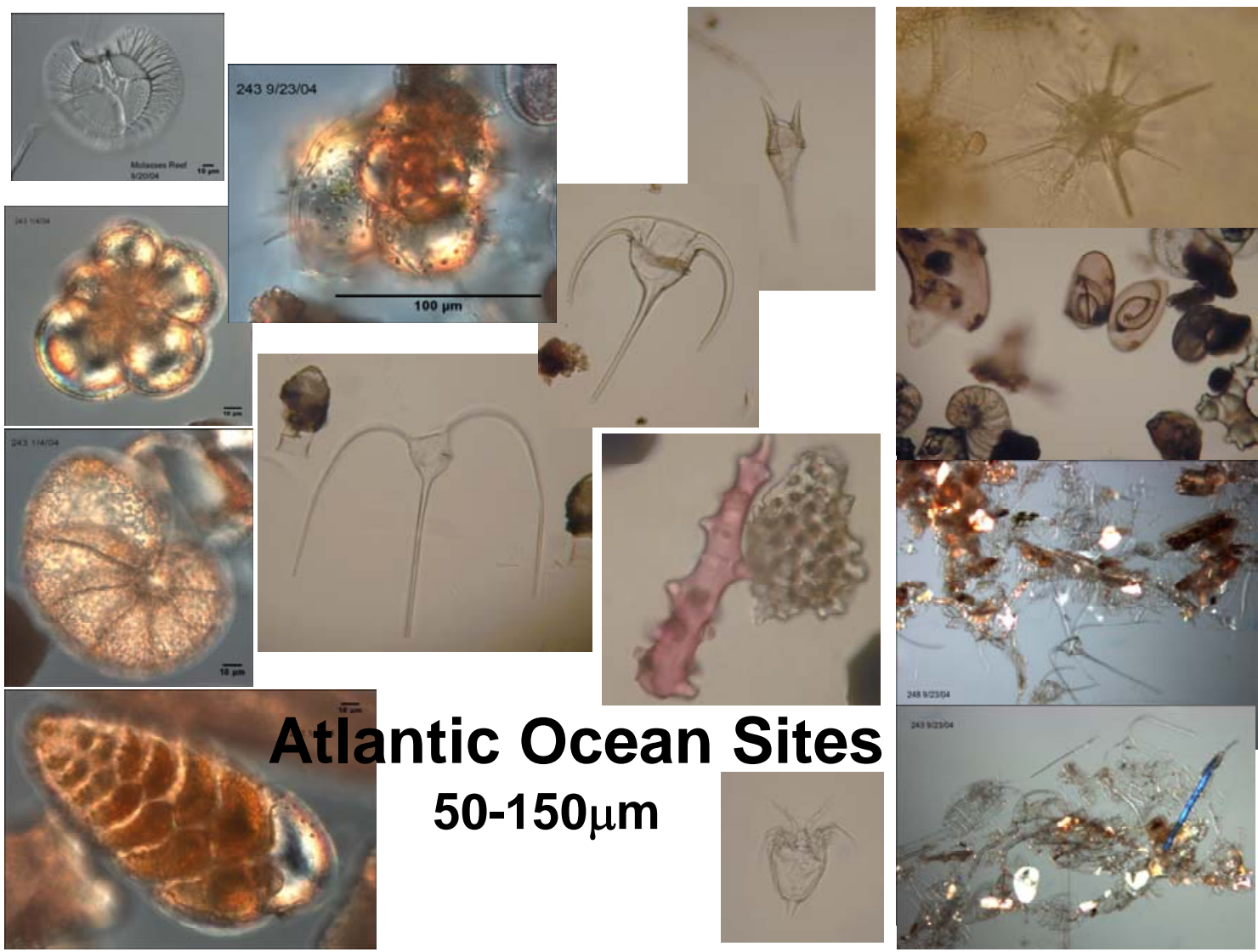

Atlantic Ocean site assemblages were composed of several species of the dinoflagellate genus, Ceratium, along with many species of both benthic and planktonic foraminifera. Amorphous organic gel and limited a limited diatom assemblage was also present. Additionally, the Atlantic sites had higher abundances of copepods and nauplii larvae. 
Appendix 4: Particulate assemblages in the 50-150 $\mu \mathrm{m}$ size fraction; bold shows dominant components

\begin{tabular}{|c|c|c|c|c|c|c|c|c|}
\hline \multirow[t]{2}{*}{ Site } & \multicolumn{8}{|c|}{ Sampling Date } \\
\hline & March 2003 & June 2003 & Sept. 2003 & Jan. 2004 & March 2005 & June 2004 & Sept. 2004 & Jan. 2005 \\
\hline Carysfort reef & 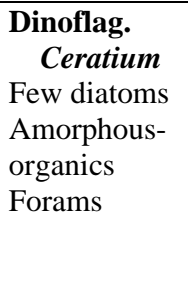 & $\begin{array}{l}\text { Green } \\
\text { filaments } \\
\text { Org. detritus } \\
\text { Forams } \\
\text { Few copepods } \\
\text { Few diatoms } \\
\text { Few dinoflag } \\
\text { (Ceratium) }\end{array}$ & $\begin{array}{l}\text { Org. Detritus } \\
\text { Ceratium } \\
\text { Few forams } \\
\text { Green filaments }\end{array}$ & $\begin{array}{l}\text { Sediment } \\
\text { Org. detritus } \\
\text { Few dinoflag. } \\
\text { Few diatoms } \\
\text { Few forams }\end{array}$ & $\begin{array}{l}\text { Sediment } \\
\text { copepods } \\
\text { Few dinoflag. } \\
\text { Few diatoms } \\
\text { Few forams } \\
\text { Green filaments }\end{array}$ & $\begin{array}{l}\text { Ceratium } \\
\text { Protoperidinium } \\
\text { Filamentous org } \\
\text { (little material) }\end{array}$ & $\begin{array}{l}\text { Clear gel org. } \\
\text { Forams } \\
\text { Plant fragments } \\
\text { No dinoflag } \\
\text { No diatoms }\end{array}$ & $\begin{array}{l}\text { Forams } \\
\text { Detritus } \\
\text { Copepods } \\
\text { Sediments } \\
\text { Organic } \\
\text { fragments }\end{array}$ \\
\hline Molasses Reef & $\begin{array}{l}\text { Dinoflag. } \\
\text { Ceratium } \\
\text { Peridinium } \\
\text { Few diatoms } \\
\text { Green algae }\end{array}$ & $\begin{array}{l}\text { Forams } \\
\text { Dinoflag. } \\
\text { Ceratium } \\
\text { Peridinium } \\
\text { Few diatoms } \\
\text { Green algae }\end{array}$ & $\begin{array}{l}\text { Org. Detritus } \\
\text { Ceratium } \\
\text { Few forams } \\
\text { Green filaments }\end{array}$ & NS & $\begin{array}{l}\text { Sediment } \\
\text { Org detritus } \\
\text { Org filaments } \\
\text { Forams } \\
\text { Copepods } \\
\text { No dinoflag. }\end{array}$ & NS & $\begin{array}{l}\text { Clear gel org. } \\
\text { Few dinoflag. } \\
\text { Few diatoms } \\
\text { Few forams } \\
\text { sediment }\end{array}$ & $\begin{array}{l}\text { Org. detritus } \\
\text { Few diatoms } \\
\text { Few dinoflag } \\
\text { Green algae }\end{array}$ \\
\hline $\begin{array}{l}\text { Tennessee } \\
\text { Reef }\end{array}$ & $\begin{array}{l}\text { Dinoflag. } \\
\text { Ceratium } \\
\text { Peridinium } \\
\text { detritus }\end{array}$ & $\begin{array}{l}\text { Dinoflag. } \\
\text { Ceratium } \\
\text { Peridinium } \\
\text { Detritus } \\
\text { copepods }\end{array}$ & $\begin{array}{l}\text { Dinoflag. } \\
\text { Ceratium } \\
\text { Peridinium } \\
\text { Detritus } \\
\text { copepods }\end{array}$ & $\begin{array}{l}\text { Sediment } \\
\text { Benthic forams } \\
\text { Coralling alg. } \\
\text { Green algae }\end{array}$ & $\begin{array}{l}\text { Benthic Forams } \\
\text { Dinoflag. } \\
\quad \text { Ceratium } \\
\text { detritus }\end{array}$ & $\begin{array}{l}\text { Dinoflag. } \\
\text { Ceratium } \\
\text { detritus }\end{array}$ & $\begin{array}{l}\text { Clear gel org. } \\
\text { Few dinoflag. } \\
\text { Few diatoms } \\
\text { Few forams } \\
\text { sediment }\end{array}$ & $\begin{array}{l}\text { Forams } \\
\text { Dinoflag. } \\
\text { Ceratium } \\
\text { Peridinium } \\
\text { Plant fragments } \\
\text { Few diatoms }\end{array}$ \\
\hline $\begin{array}{l}\text { Coffins Patch } \\
\text { Channel }\end{array}$ & $\begin{array}{l}\text { Dinoflag. } \\
\text { Certaium } \\
\text { Copepods } \\
\text { Few diatoms }\end{array}$ & $\begin{array}{l}\text { Detritus } \\
\text { Dinoflag. } \\
\text { Ceratium } \\
\text { Copepods }\end{array}$ & $\begin{array}{l}\text { Forams } \\
\text { Dinoflag. } \\
\text { Ceratium } \\
\text { Peridinium } \\
\text { copepods } \\
\text { Green algae }\end{array}$ & $\begin{array}{l}\text { Sediment } \\
\text { Org. detritus } \\
\text { Forams } \\
\text { Rare diatoms }\end{array}$ & $\begin{array}{l}\text { Forams } \\
\text { Dinoflag. } \\
\text { Ceratium } \\
\text { Detritus } \\
\text { copepods } \\
\text { Green algae }\end{array}$ & $\begin{array}{l}\text { Forams } \\
\text { Dinoflag. } \\
\quad \text { Ceratium } \\
\text { copepods } \\
\text { rare diatoms }\end{array}$ & $\begin{array}{l}\text { Forams } \\
\text { Dinoflag. } \\
\text { Ceratium } \\
\text { Detritus } \\
\text { Clear gel org. }\end{array}$ & $\begin{array}{l}\text { Forams } \\
\text { Sediment } \\
\text { Dinoflag. } \\
\text { Ceratium } \\
\text { Few diatoms. }\end{array}$ \\
\hline $\begin{array}{l}\text { Bahia Honda } \\
\text { Channel }\end{array}$ & $\begin{array}{l}\text { Diatoms } \\
\text { Forams } \\
\text { Dinoflag. } \\
\text { Brown } \\
\text { organics }\end{array}$ & 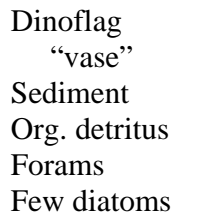 & $\begin{array}{l}\text { Detritus } \\
\text { Dinoflag. } \\
\text { Ceratium } \\
\text { Peridinium } \\
\text { Forams } \\
\text { Few diatoms }\end{array}$ & NS & $\begin{array}{l}\text { Sediments } \\
\text { Forams } \\
\text { Rare Ceratium } \\
\text { Rare diatoms }\end{array}$ & $\begin{array}{l}\text { Forams } \\
\text { Dinoflag. } \\
\quad \text { Ceratium } \\
\text { copepods } \\
\text { rare diatoms }\end{array}$ & $\begin{array}{l}\text { Forams } \\
\text { Dinoflag. } \\
\quad \text { Ceratium } \\
\text { copepods } \\
\text { diatoms } \\
\text { detritus }\end{array}$ & $\begin{array}{l}\text { Sediments } \\
\text { Forams } \\
\text { Ceratium } \\
\text { diatoms }\end{array}$ \\
\hline
\end{tabular}




\begin{tabular}{|c|c|c|c|c|c|c|c|c|}
\hline Tripod Bank & $\begin{array}{l}\text { Diatoms } \\
\text { forams }\end{array}$ & DIATOMS & $\begin{array}{l}\text { DIATOMS } \\
\text { Rhabdonema } \\
\text { Forams }\end{array}$ & DIATOMS & DIATOMS & DIATOMS & DIATOMS & $\begin{array}{l}\text { DIATOMS } \\
\text { Org. detritus }\end{array}$ \\
\hline Bamboo Bank & $\begin{array}{l}\text { Diatoms } \\
\text { forams }\end{array}$ & $\begin{array}{l}\text { DIATOMS } \\
\text { Rhabdonema } \\
\text { Rhizosolenia }\end{array}$ & $\begin{array}{l}\text { DIATOMS } \\
\text { Rhabdonema } \\
\text { forams }\end{array}$ & $\begin{array}{l}\text { DIATOMS } \\
\text { Rhabdonema } \\
\text { Rhizosolenia } \\
\text { Campylodiscus } \\
\text { forams }\end{array}$ & $\begin{array}{l}\text { DIATOMS } \\
\text { Rhabdonema } \\
\text { Rhizosolenia } \\
\text { Campylodiscus }\end{array}$ & $\begin{array}{l}\text { DIATOMS } \\
\text { Rhabdonema } \\
\text { Rhizosolenia } \\
\text { Campylodiscus } \\
\text { Green algae }\end{array}$ & $\begin{array}{l}\text { DIATOMS } \\
\text { Rhabdonema } \\
\text { Rhizosolenia } \\
\text { Campylodiscu } \\
\text { licomorphs }\end{array}$ & $\begin{array}{l}\text { DIATOMS } \\
\text { Org. detritus }\end{array}$ \\
\hline Sprigger Bank & NS & $\begin{array}{l}\text { DIATOMS } \\
\text { Detritus } \\
\text { Sediment } \\
\text { forams }\end{array}$ & $\begin{array}{l}\text { DIATOMS } \\
\text { Forams } \\
\text { copepods }\end{array}$ & $\begin{array}{l}\text { DIATOMS } \\
\text { Rhabdonema } \\
\text { Rhizosolenia } \\
\text { Coscinodiscus } \\
\text { Forams }\end{array}$ & $\begin{array}{l}\text { DIATOMS } \\
\text { Detritus } \\
\text { Sediment } \\
\text { forams }\end{array}$ & $\begin{array}{l}\text { Fewer diatoms } \\
\text { but still } \\
\text { dominant } \\
\text { Forams } \\
\text { Clam larvae }\end{array}$ & $\begin{array}{l}\text { DIATOMS } \\
\text { Detritus } \\
\text { Sediment } \\
\text { forams }\end{array}$ & $\begin{array}{l}\text { DIATOMS } \\
\text { Rhabdonema } \\
\text { Rhizosolenia } \\
\text { Coscinodiscus }\end{array}$ \\
\hline $\begin{array}{l}\text { Bob Allen } \\
\text { Bank }\end{array}$ & NS & $\begin{array}{l}\text { Dinoflag } \\
\text { BLOOM } \\
\text { Protoperidinium }\end{array}$ & $\begin{array}{l}\text { Dinoflag } \\
\text { decaying } \\
\text { Protoperidinium }\end{array}$ & $\begin{array}{l}\text { DIATOMS } \\
\text { Forams } \\
\text { Some dinoflag. }\end{array}$ & $\begin{array}{l}\text { Dinoflag } \\
\text { Protoperidinium } \\
\text { Detritus } \\
\text { Sediments } \\
\text { Diatoms } \\
\text { Green algae }\end{array}$ & $\begin{array}{l}\text { Dinoflag } \\
\text { BLOOM } \\
\text { Protoperidinium }\end{array}$ & $\begin{array}{l}\text { Dinoflag } \\
\text { decaying } \\
\text { Protoperidinium } \\
\text { Sediments } \\
\text { Org. detritus } \\
\text { Forams } \\
\text { Green algae }\end{array}$ & 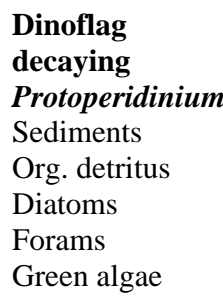 \\
\hline Duck Key & NS & $\begin{array}{l}\text { Dinoflag } \\
\text { BLOOM } \\
\text { Protoperidinium }\end{array}$ & $\begin{array}{l}\text { Dinoflag } \\
\text { decaying } \\
\text { Protoperidinium } \\
\text { Forams }\end{array}$ & $\begin{array}{l}\text { Dinoflag } \\
\text { decaying } \\
\text { Protoperidinium } \\
\text { Forams }\end{array}$ & $\begin{array}{l}\text { Diatoms } \\
\text { Green algae } \\
\text { Detritus } \\
\text { dinoflag }\end{array}$ & $\begin{array}{l}\text { Dinoflag } \\
\text { BLOOM } \\
\text { Protoperidinium }\end{array}$ & $\begin{array}{l}\text { Dinoflag } \\
\text { decaying } \\
\text { Protoperidinium } \\
\text { Sediments } \\
\text { Green algae }\end{array}$ & $\begin{array}{l}\text { Org. Detritus } \\
\text { Forams } \\
\text { Centric diatoms } \\
\text { Rhabdonema }\end{array}$ \\
\hline
\end{tabular}




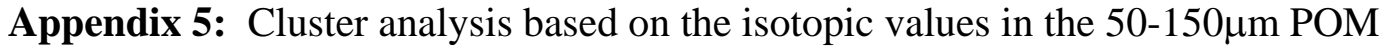
fraction.
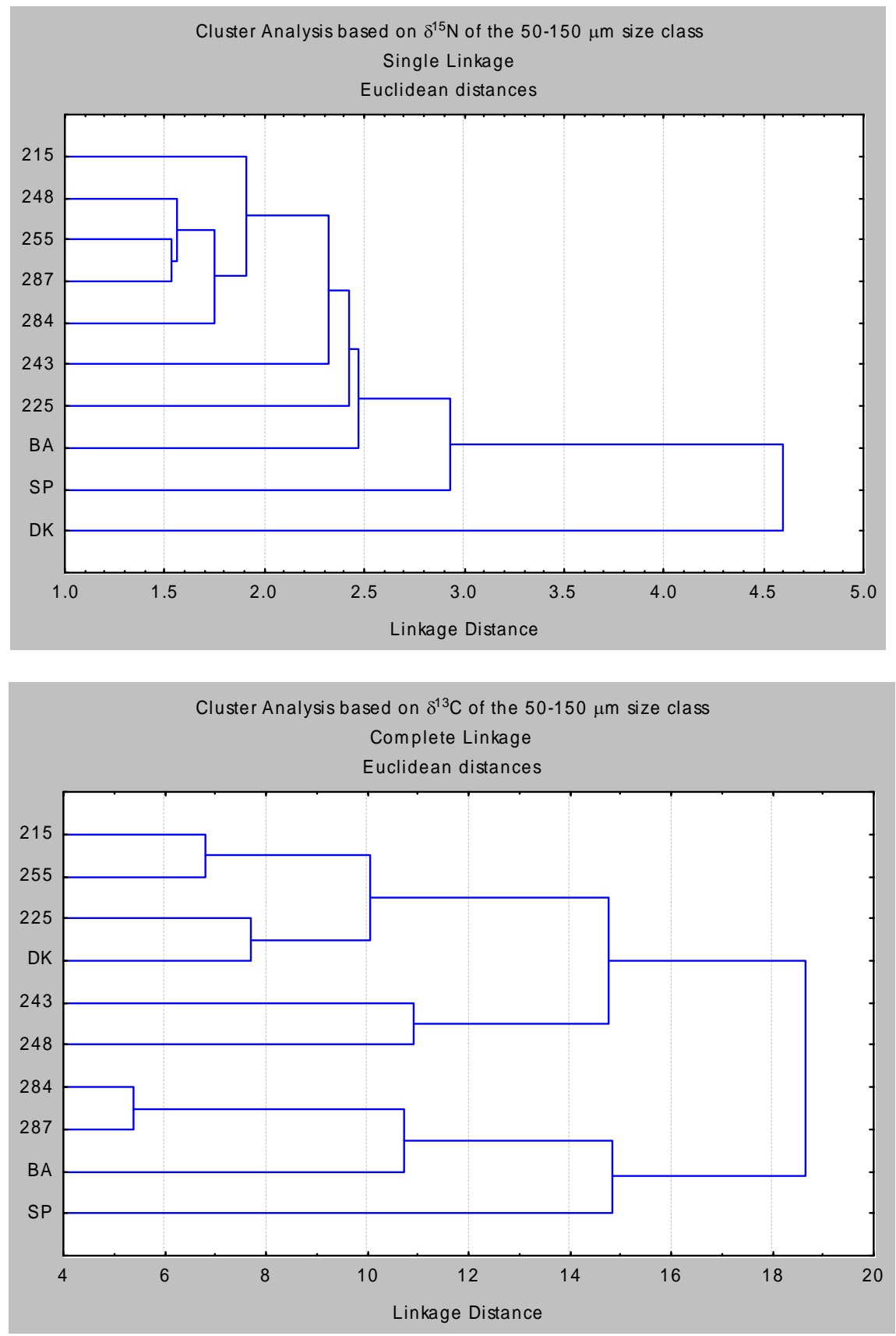

Clustering based on $\delta^{13} \mathrm{C}$ yielded 2 main groups, Florida Bay sites (SP, BA, 287, 284) and Atlantic Ocean sites (215, 225, 255, 243, 248); however Duck Key (DK) was 
grouped with the Atlantic side. $\mathrm{D}^{15} \mathrm{~N}$ values were able to separate the Florida Bay proper sites (Duck Key, Bob Allen Bank, and Sprigger Bank), however grouped the extreme western sites $(284,287)$ with the Atlantic Ocean sites. 
Appendix 6: Trout Creek Core Geochemical Dataset

\begin{tabular}{|c|c|c|c|c|c|c|c|c|c|c|c|c|c|c|c|}
\hline Depth & $\begin{array}{c}\text { Bulk } \\
\text { Density } \\
\text { (dry) }\end{array}$ & MAR* & $\% \mathrm{C}$ & $\% \mathrm{~N}$ & $\% \mathrm{P}$ & $\begin{array}{l}\text { MAR- } \\
\text { OC** }\end{array}$ & $\begin{array}{c}\text { MAR- } \\
\mathrm{N}^{* *}\end{array}$ & $\begin{array}{c}\text { MAR- } \\
\mathrm{P}^{* *}\end{array}$ & $\begin{array}{c}\text { Total IC } \\
(\%)\end{array}$ & $\begin{array}{c}\text { Total } \\
\text { OC (\%) }\end{array}$ & $\begin{array}{c}\delta^{15} \mathrm{~N} \\
\text { (\%o AIR) }\end{array}$ & $\begin{array}{c}\delta^{13} \mathrm{C} \\
\text { (\%o PDB) }\end{array}$ & $\mathrm{C} / \mathrm{N}$ & $\mathrm{C} / \mathrm{P}$ & N/P \\
\hline $0-2$ & 0.68 & 0.406 & 12.14 & 0.17 & 0.021 & 5.774 & 0.678 & 0.084 & 10.72 & 1.42 & 5.91 & -19.64 & 9.9 & 177.2 & 17.8 \\
\hline $2-4$ & 0.73 & 0.440 & 12.08 & 0.15 & 0.013 & 5.621 & 0.671 & 0.059 & 10.81 & 1.28 & 6.47 & -19.79 & 9.8 & 245.1 & 25.1 \\
\hline 4-6 & 0.83 & 0.497 & 12.07 & 0.14 & 0.013 & 6.429 & 0.698 & 0.065 & 10.78 & 1.29 & 5.75 & -19.79 & 10.7 & 256.8 & 23.9 \\
\hline $6-8$ & 0.73 & 0.439 & 12.16 & 0.13 & 0.011 & 6.749 & 0.590 & 0.049 & 10.63 & 1.54 & 6.17 & -20.67 & 13.3 & 354.0 & 26.5 \\
\hline $8-10$ & 0.69 & 0.416 & 12.01 & 0.13 & 0.015 & 5.884 & 0.525 & 0.061 & 10.60 & 1.41 & 5.72 & -19.73 & 13.1 & 248.4 & 19.0 \\
\hline $10-12$ & 0.85 & 0.513 & 11.91 & 0.12 & 0.012 & 6.523 & 0.590 & 0.064 & 10.63 & 1.27 & 6.44 & -19.64 & 12.9 & 265.0 & 20.5 \\
\hline $12-14$ & 0.95 & 0.567 & 12.07 & 0.11 & 0.012 & 7.819 & 0.644 & 0.069 & 10.69 & 1.38 & 5.83 & -20.20 & 14.2 & 292.9 & 20.7 \\
\hline $14-16$ & 0.74 & 0.443 & 12.10 & 0.12 & 0.012 & 6.370 & 0.536 & 0.055 & 10.67 & 1.44 & 6.62 & -19.86 & 13.9 & 301.8 & 21.8 \\
\hline $16-18$ & 0.84 & 0.504 & 12.07 & 0.09 & 0.010 & 6.005 & 0.472 & 0.053 & 10.88 & 1.19 & 5.00 & -20.32 & 14.9 & 294.1 & 19.8 \\
\hline $18-20$ & 0.46 & 0.278 & 12.05 & 0.10 & 0.042 & 3.366 & 0.277 & 0.116 & 10.84 & 1.21 & 7.58 & -19.99 & 14.2 & 75.2 & 5.3 \\
\hline $20-22$ & 0.43 & 0.259 & 12.01 & 0.12 & 0.019 & 3.732 & 0.302 & 0.048 & 10.57 & 1.44 & 5.91 & -19.50 & 14.4 & 199.9 & 13.9 \\
\hline $22-24$ & 0.98 & 0.590 & 12.24 & 0.13 & 0.010 & 11.245 & 0.766 & 0.060 & 10.34 & 1.91 & 5.33 & -21.42 & 17.1 & 484.1 & 28.3 \\
\hline 24-26 & 0.81 & 0.488 & 12.06 & 0.13 & 0.010 & 8.476 & 0.635 & 0.050 & 10.33 & 1.74 & 5.61 & -19.26 & 15.6 & 438.3 & 28.1 \\
\hline $26-28$ & 0.85 & 0.508 & 12.04 & 0.13 & 0.010 & 9.868 & 0.671 & 0.049 & 10.10 & 1.94 & 5.98 & -19.29 & 17.2 & 524.0 & 30.5 \\
\hline 28-30 & 0.77 & 0.463 & 12.05 & 0.16 & 0.011 & 9.344 & 0.761 & 0.052 & 10.03 & 2.02 & 6.97 & -19.21 & 14.3 & 459.9 & 32.1 \\
\hline 30-32 & 0.63 & 0.380 & 11.97 & 0.13 & 0.007 & 7.198 & 0.495 & 0.027 & 10.08 & 1.89 & 5.85 & -19.44 & 17.0 & 686.2 & 40.4 \\
\hline $32-34$ & 0.64 & 0.385 & 12.34 & 0.13 & 0.007 & 8.945 & 0.518 & 0.025 & 10.01 & 2.32 & 5.20 & -20.10 & 20.1 & 919.4 & 45.6 \\
\hline 34-36 & 0.67 & 0.405 & 12.32 & 0.13 & 0.006 & 9.225 & 0.528 & 0.026 & 10.04 & 2.28 & 5.88 & -20.28 & 20.4 & 916.2 & 45.0 \\
\hline 36-38 & 0.76 & 0.455 & 11.91 & 0.13 & 0.007 & 8.557 & 0.596 & 0.031 & 10.03 & 1.88 & 5.47 & -19.88 & 16.8 & 713.5 & 42.6 \\
\hline $38-40$ & 0.65 & 0.389 & 11.99 & 0.14 & 0.006 & 7.612 & 0.531 & 0.022 & 10.03 & 1.96 & 5.85 & -20.05 & 16.7 & 887.9 & 53.1 \\
\hline $40-42$ & 0.76 & 0.458 & 12.65 & 0.14 & 0.006 & 10.990 & 0.621 & 0.026 & 10.25 & 2.40 & 5.26 & -21.26 & 20.7 & 1081.9 & 52.4 \\
\hline $42-44$ & 0.82 & 0.490 & 12.20 & 0.15 & 0.006 & 10.997 & 0.711 & 0.030 & 9.95 & 2.24 & 5.23 & -20.51 & 18.0 & 938.1 & 52.0 \\
\hline $44-46$ & 0.84 & 0.506 & 12.04 & 0.14 & 0.006 & 10.436 & 0.693 & 0.030 & 9.98 & 2.06 & 5.54 & -20.10 & 17.6 & 890.0 & 50.7 \\
\hline $46-48$ & 0.79 & 0.475 & 12.03 & 0.14 & 0.006 & 9.703 & 0.674 & 0.029 & 9.98 & 2.04 & 4.89 & -19.67 & 16.8 & 867.5 & 51.6 \\
\hline $48-50$ & 0.97 & 0.583 & 12.13 & 0.14 & 0.004 & 11.810 & 0.804 & 0.026 & 10.10 & 2.03 & 4.91 & -20.72 & 17.1 & 1188.9 & 69.4 \\
\hline 50-52 & 0.86 & 0.516 & 11.95 & 0.13 & 0.004 & 9.493 & 0.647 & 0.022 & 10.11 & 1.84 & 4.74 & -19.24 & 17.1 & 1138.1 & 66.5 \\
\hline $52-54$ & 0.72 & 0.435 & 11.96 & 0.12 & 0.004 & 7.910 & 0.537 & 0.018 & 10.14 & 1.82 & 5.14 & -18.97 & 17.2 & 1110.3 & 64.6 \\
\hline $54-56$ & 0.78 & 0.468 & 11.95 & 0.12 & 0.004 & 8.623 & 0.574 & 0.020 & 10.10 & 1.84 & 4.85 & -19.13 & 17.5 & 1124.3 & 64.1 \\
\hline $56-58$ & 0.66 & 0.396 & 11.66 & 0.11 & 0.004 & 5.609 & 0.453 & 0.017 & 10.24 & 1.42 & 5.34 & -19.61 & 14.4 & 855.3 & 59.2 \\
\hline
\end{tabular}




\begin{tabular}{|c|c|c|c|c|c|c|c|c|c|c|c|c|c|c|c|}
\hline Depth & $\begin{array}{c}\text { Bulk } \\
\text { Density } \\
\text { (dry) }\end{array}$ & MAR* & $\% \mathrm{C}$ & $\% \mathrm{~N}$ & $\% \mathrm{P}$ & $\begin{array}{l}\text { MAR- } \\
\text { OC** }\end{array}$ & $\begin{array}{c}\text { MAR- } \\
\mathrm{N}^{* *}\end{array}$ & $\begin{array}{c}\text { MAR- } \\
\mathrm{P}^{* *}\end{array}$ & $\begin{array}{c}\text { Total IC } \\
(\%)\end{array}$ & $\begin{array}{c}\text { Total } \\
\text { OC (\%) }\end{array}$ & $\begin{array}{c}\delta^{15} \mathrm{~N} \\
\text { (\%o AIR) }\end{array}$ & $\begin{array}{c}\delta^{13} \mathrm{C} \\
\text { (\% } \mathrm{PDB})\end{array}$ & $\mathrm{C} / \mathrm{N}$ & $\mathrm{C} / \mathrm{P}$ & $\mathrm{N} / \mathrm{P}$ \\
\hline $58-60$ & 0.78 & 0.470 & 11.72 & 0.12 & 0.005 & 6.943 & 0.571 & 0.023 & 10.24 & 1.48 & 4.99 & -19.52 & 14.2 & 790.9 & 55.7 \\
\hline $60-62$ & 0.92 & 0.552 & 11.67 & 0.11 & 0.004 & 8.465 & 0.632 & 0.024 & 10.14 & 1.53 & 5.47 & -19.61 & 15.6 & 927.0 & 59.3 \\
\hline $62-64$ & 0.81 & 0.484 & 11.76 & 0.12 & 0.004 & 7.876 & 0.556 & 0.019 & 10.13 & 1.63 & 5.28 & -19.38 & 16.5 & 1072.9 & 65.0 \\
\hline 64-66 & 0.90 & 0.541 & 11.75 & 0.10 & 0.004 & 8.220 & 0.563 & 0.019 & 10.23 & 1.52 & 5.20 & -19.39 & 17.0 & 1104.4 & 64.8 \\
\hline $66-68$ & 0.83 & 0.501 & 11.71 & 0.11 & 0.004 & 7.692 & 0.553 & 0.019 & 10.17 & 1.54 & 5.32 & -18.68 & 16.2 & 1027.4 & 63.3 \\
\hline $68-70$ & 0.80 & 0.483 & 11.76 & 0.11 & 0.004 & 7.326 & 0.528 & 0.018 & 10.24 & 1.52 & 5.53 & -19.42 & 16.2 & 1070.6 & 66.2 \\
\hline $70-72$ & 0.77 & 0.464 & 11.73 & 0.11 & 0.003 & 7.040 & 0.490 & 0.015 & 10.22 & 1.52 & 5.20 & -19.48 & 16.8 & 1173.7 & 70.0 \\
\hline $72-74$ & 0.94 & 0.566 & 11.76 & 0.11 & 0.003 & 8.676 & 0.597 & 0.018 & 10.22 & 1.53 & 5.18 & -19.62 & 17.0 & 1277.2 & 75.3 \\
\hline 74-76 & 0.91 & 0.548 & 11.75 & 0.10 & 0.004 & 8.376 & 0.570 & 0.022 & 10.22 & 1.53 & 5.10 & -19.32 & 17.1 & 978.4 & 57.1 \\
\hline $76-78$ & 0.98 & 0.591 & 11.66 & 0.09 & 0.004 & 7.848 & 0.550 & 0.026 & 10.33 & 1.33 & 5.07 & -18.87 & 16.7 & 788.1 & 47.3 \\
\hline $78-80$ & 0.94 & 0.563 & 11.64 & 0.10 & 0.004 & 7.540 & 0.566 & 0.021 & 10.30 & 1.34 & 5.35 & -19.78 & 15.5 & 932.2 & 60.0 \\
\hline $80-82$ & 0.92 & 0.551 & 11.64 & 0.10 & 0.003 & 7.351 & 0.523 & 0.017 & 10.31 & 1.33 & 5.77 & -19.46 & 16.4 & 1094.7 & 66.8 \\
\hline $82-84$ & 0.90 & 0.540 & 11.57 & 0.08 & 0.004 & 6.280 & 0.448 & 0.022 & 10.40 & 1.16 & 5.88 & -18.79 & 16.3 & 742.6 & 45.4 \\
\hline $84-86$ & 0.92 & 0.554 & 11.52 & 0.08 & 0.003 & 7.609 & 0.443 & 0.015 & 10.14 & 1.37 & 5.99 & -18.43 & 20.0 & 1290.2 & 64.4 \\
\hline $86-88$ & 0.93 & 0.561 & 11.50 & 0.08 & 0.003 & 6.032 & 0.463 & 0.017 & 10.42 & 1.08 & 6.50 & -18.79 & 15.2 & 908.4 & 59.7 \\
\hline $88-90$ & 0.86 & 0.516 & 11.51 & 0.08 & 0.004 & 4.967 & 0.410 & 0.019 & 10.55 & 0.96 & 6.27 & -19.08 & 14.1 & 664.5 & 47.0 \\
\hline $90-92$ & 0.98 & 0.587 & 11.49 & 0.08 & 0.003 & 6.655 & 0.481 & 0.020 & 10.36 & 1.13 & 6.19 & -18.94 & 16.1 & 868.9 & 53.9 \\
\hline $92-96$ & 1.28 & 0.766 & 11.34 & 0.09 & 0.004 & 9.424 & 0.663 & 0.028 & 10.11 & 1.23 & 5.84 & -19.33 & 16.6 & 865.4 & 52.2 \\
\hline
\end{tabular}

*MAR - Mass Accumulation Rate, expressed as g/ $\mathrm{cm}^{2} / \mathrm{yr}$

**MAR expressed as $\mathrm{mg} / \mathrm{cm}^{2} / \mathrm{yr}$ 
Appendix 7: Russell Bank Core Geochemical Dataset

\begin{tabular}{|c|c|c|c|c|c|c|c|c|c|c|c|c|c|c|c|}
\hline Depth & $\begin{array}{c}\text { Bulk } \\
\text { Density } \\
\text { (dry) }\end{array}$ & MAR* & $\% \mathrm{C}$ & $\% \mathrm{~N}$ & $\% \mathrm{P}$ & $\begin{array}{l}\text { MAR- } \\
\text { OC** }\end{array}$ & $\begin{array}{c}\text { MAR- } \\
\mathrm{N}^{* *}\end{array}$ & $\begin{array}{c}\text { MAR- } \\
\mathrm{P}^{* *}\end{array}$ & $\begin{array}{c}\text { Total } \\
\text { IC } \\
(\%) \\
\end{array}$ & $\begin{array}{c}\text { Total } \\
\text { OC } \\
(\%) \\
\end{array}$ & $\begin{array}{c}\delta^{15} \mathrm{~N} \\
\text { (\%o AIR) }\end{array}$ & $\begin{array}{c}\delta^{13} \mathrm{C} \\
\text { (\% } \% \text { PDB) }\end{array}$ & $\mathrm{C} / \mathrm{N}$ & $\mathrm{C} / \mathrm{P}$ & N/P \\
\hline $0-2$ & 0.77 & 0.852 & 11.98 & 0.25 & 0.009 & 20.269 & 2.159 & 0.079 & 9.59 & 2.38 & 4.77 & -12.71 & 11.0 & 666.6 & 60.9 \\
\hline $2-4$ & 0.56 & 0.621 & 12.04 & 0.22 & 0.007 & 13.793 & 1.336 & 0.042 & 9.82 & 2.22 & 4.64 & -12.63 & 12.0 & 858.4 & 71.3 \\
\hline 4-6 & 0.50 & 0.548 & 12.27 & 0.23 & 0.008 & 12.502 & 1.286 & 0.043 & 9.99 & 2.28 & 4.44 & -12.27 & 11.3 & 755.3 & 66.6 \\
\hline $6-8$ & 0.57 & 0.630 & 12.09 & 0.20 & 0.007 & 14.165 & 1.284 & 0.041 & 9.84 & 2.25 & 4.48 & -12.23 & 12.9 & 892.1 & 69.3 \\
\hline $8-10$ & 0.61 & 0.669 & 12.15 & 0.21 & 0.007 & 15.596 & 1.399 & 0.045 & 9.82 & 2.33 & 4.55 & -12.10 & 13.0 & 905.3 & 69.6 \\
\hline 10-12 & 0.57 & 0.624 & 12.16 & 0.22 & 0.007 & 14.166 & 1.373 & 0.042 & 9.89 & 2.27 & 4.38 & -12.24 & 12.0 & 865.2 & 71.9 \\
\hline $12-14$ & 0.68 & 0.751 & 12.07 & 0.19 & 0.006 & 14.500 & 1.424 & 0.047 & 10.14 & 1.93 & 4.86 & -12.43 & 11.9 & 791.5 & 66.6 \\
\hline $14-16$ & 0.65 & 0.713 & 12.11 & 0.18 & 0.006 & 13.187 & 1.290 & 0.041 & 10.26 & 1.85 & 4.80 & -12.24 & 11.9 & 834.9 & 70.0 \\
\hline $16-18$ & 0.62 & 0.680 & 12.08 & 0.19 & 0.005 & 13.260 & 1.278 & 0.035 & 10.14 & 1.95 & 4.77 & -12.28 & 12.1 & 986.7 & 81.5 \\
\hline $18-20$ & 0.64 & 0.709 & 12.07 & 0.19 & 0.006 & 14.746 & 1.361 & 0.046 & 9.99 & 2.08 & 4.83 & -12.11 & 12.6 & 835.8 & 66.1 \\
\hline 20-22 & 0.64 & 0.701 & 12.06 & 0.20 & 0.006 & 14.937 & 1.395 & 0.044 & 9.92 & 2.13 & 5.01 & -12.01 & 12.5 & 881.2 & 70.6 \\
\hline $22-24$ & 0.67 & 0.740 & 12.08 & 0.19 & 0.007 & 16.213 & 1.425 & 0.051 & 9.9 & 2.19 & 5.33 & -12.01 & 13.3 & 817.2 & 61.6 \\
\hline $24-26$ & 0.65 & 0.713 & 12.10 & 0.19 & 0.006 & 13.682 & 1.382 & 0.043 & 10.18 & 1.92 & 5.21 & -11.91 & 11.5 & 829.7 & 71.9 \\
\hline $26-28$ & 0.64 & 0.703 & 12.09 & 0.18 & 0.006 & 14.402 & 1.261 & 0.039 & 10.04 & 2.05 & 5.32 & -11.97 & 13.3 & 952.1 & 71.5 \\
\hline 28-30 & 0.57 & 0.631 & 12.22 & 0.21 & 0.006 & 14.257 & 1.350 & 0.039 & 9.97 & 2.26 & 4.93 & -11.47 & 12.3 & 950.1 & 77.1 \\
\hline 30-32 & 0.56 & 0.615 & 12.09 & 0.19 & 0.006 & 13.663 & 1.139 & 0.039 & 9.87 & 2.22 & 5.25 & -11.76 & 14.0 & 900.3 & 64.3 \\
\hline 32-34 & 0.53 & 0.579 & 12.12 & 0.20 & 0.007 & 13.672 & 1.185 & 0.039 & 9.76 & 2.36 & 5.68 & -11.87 & 13.5 & 903.0 & 67.1 \\
\hline 34-36 & 0.73 & 0.806 & 11.94 & 0.16 & 0.006 & 16.614 & 1.258 & 0.051 & 9.88 & 2.06 & 5.79 & -12.11 & 15.4 & 845.0 & 54.8 \\
\hline 36-38 & 0.74 & 0.811 & 12.00 & 0.16 & 0.006 & 15.248 & 1.294 & 0.047 & 10.12 & 1.88 & 5.70 & -12.06 & 13.8 & 844.5 & 61.4 \\
\hline $38-40$ & 0.72 & 0.790 & 11.98 & 0.16 & 0.005 & 14.216 & 1.268 & 0.042 & 10.19 & 1.8 & 5.51 & -11.94 & 13.1 & 875.0 & 66.9 \\
\hline $40-42$ & 0.77 & 0.845 & 12.05 & 0.16 & 0.005 & 15.541 & 1.351 & 0.044 & 10.21 & 1.84 & 5.46 & -11.90 & 13.4 & 919.7 & 68.6 \\
\hline $42-44$ & 0.69 & 0.760 & 12.06 & 0.16 & 0.006 & 16.578 & 1.202 & 0.044 & 9.88 & 2.18 & 5.33 & -11.87 & 16.1 & 978.9 & 60.8 \\
\hline $44-46$ & 0.79 & 0.869 & 12.10 & 0.15 & 0.006 & 18.940 & 1.342 & 0.049 & 9.91 & 2.18 & 5.37 & -11.57 & 16.5 & 998.9 & 60.7 \\
\hline $46-48$ & 0.74 & 0.810 & 12.10 & 0.15 & 0.006 & 18.378 & 1.239 & 0.048 & 9.83 & 2.27 & 5.16 & -11.50 & 17.3 & 999.5 & 57.7 \\
\hline $48-50$ & 0.81 & 0.890 & 12.13 & 0.16 & 0.006 & 20.124 & 1.411 & 0.052 & 9.87 & 2.26 & 4.92 & -11.48 & 16.6 & 990.6 & 59.5 \\
\hline $50-52$ & 0.88 & 0.970 & 12.07 & 0.15 & 0.006 & 21.332 & 1.493 & 0.058 & 9.87 & 2.2 & 5.06 & -11.50 & 16.7 & 945.8 & 56.7 \\
\hline $52-54$ & 0.84 & 0.926 & 12.08 & 0.16 & 0.006 & 20.566 & 1.478 & 0.059 & 9.87 & 2.22 & 5.21 & -11.50 & 16.2 & 893.6 & 55.0 \\
\hline $54-56$ & 0.80 & 0.882 & 12.04 & 0.16 & 0.007 & 20.366 & 1.397 & 0.065 & 9.73 & 2.31 & 5.26 & -11.65 & 17.0 & 808.8 & 47.6 \\
\hline $56-58$ & 0.79 & 0.870 & 12.02 & 0.16 & 0.006 & 25.222 & 1.352 & 0.055 & 9.12 & 2.9 & 5.05 & -11.71 & 21.8 & 1191.2 & 54.7 \\
\hline
\end{tabular}




\begin{tabular}{|c|c|c|c|c|c|c|c|c|c|c|c|c|c|c|c|}
\hline Depth & $\begin{array}{c}\text { Bulk } \\
\text { Density } \\
\text { (dry) }\end{array}$ & MAR* & $\% \mathrm{C}$ & $\% \mathrm{~N}$ & $\% \mathrm{P}$ & $\begin{array}{l}\text { MAR- } \\
\mathrm{OC}^{* *}\end{array}$ & $\begin{array}{c}\text { MAR- } \\
\mathrm{N}^{* *}\end{array}$ & $\begin{array}{c}\text { MAR- } \\
\mathrm{P}^{* *}\end{array}$ & $\begin{array}{c}\text { Total } \\
\text { IC } \\
(\%) \\
\end{array}$ & $\begin{array}{c}\text { Total } \\
\text { OC } \\
(\%) \\
\end{array}$ & $\begin{array}{c}\delta^{15} \mathrm{~N} \\
\text { (\%о AIR) }\end{array}$ & $\begin{array}{c}\delta^{13} \mathrm{C} \\
\text { (\% PDB) }\end{array}$ & $\mathrm{C} / \mathrm{N}$ & $\mathrm{C} / \mathrm{P}$ & $\mathrm{N} / \mathrm{P}$ \\
\hline $58-60$ & 0.76 & 0.834 & 11.97 & 0.15 & 0.007 & 16.683 & 1.239 & 0.055 & 9.97 & 2 & 5.78 & -11.86 & 15.7 & 778.8 & 49.6 \\
\hline $60-62$ & 0.82 & 0.901 & 12.02 & 0.16 & 0.007 & 17.849 & 1.429 & 0.064 & 10.04 & 1.98 & 5.56 & -11.64 & 14.6 & 718.9 & 49.3 \\
\hline $62-64$ & 0.78 & 0.854 & 12.05 & 0.16 & 0.006 & 19.381 & 1.328 & 0.051 & 9.78 & 2.27 & 5.70 & -11.35 & 17.0 & 976.4 & 57.3 \\
\hline 64-66 & 0.88 & 0.970 & 12.12 & 0.16 & 0.007 & 22.015 & 1.561 & 0.065 & 9.85 & 2.27 & 5.51 & -11.67 & 16.4 & 871.9 & 53.0 \\
\hline $66-68$ & 0.85 & 0.940 & 12.16 & 0.17 & 0.007 & 22.187 & 1.603 & 0.067 & 9.81 & 2.36 & 5.37 & -11.46 & 16.1 & 861.9 & 53.4 \\
\hline $68-70$ & 0.84 & 0.925 & 12.20 & 0.16 & 0.007 & 22.383 & 1.508 & 0.061 & 9.77 & 2.42 & 5.27 & -11.45 & 17.3 & 943.9 & 54.5 \\
\hline 70-72 & 0.94 & 1.034 & 12.13 & 0.16 & 0.008 & 23.567 & 1.664 & 0.079 & 9.85 & 2.28 & 5.34 & -11.53 & 16.5 & 767.0 & 46.4 \\
\hline $72-74$ & 0.90 & 0.995 & 12.13 & 0.17 & 0.007 & 23.079 & 1.646 & 0.071 & 9.81 & 2.32 & 5.43 & -11.35 & 16.4 & 842.5 & 51.5 \\
\hline 74-76 & 0.89 & 0.979 & 12.13 & 0.16 & 0.007 & 22.125 & 1.571 & 0.067 & 9.87 & 2.26 & 5.21 & -11.41 & 16.4 & 849.6 & 51.7 \\
\hline 76-78 & 0.92 & 1.014 & 12.19 & 0.17 & 0.007 & 21.704 & 1.689 & 0.071 & 10.05 & 2.14 & 5.15 & -11.24 & 15.0 & 785.5 & 52.4 \\
\hline $78-80$ & 0.94 & 1.029 & 12.21 & 0.17 & 0.007 & 23.038 & 1.774 & 0.070 & 9.98 & 2.24 & 5.04 & -11.00 & 15.1 & 845.6 & 55.8 \\
\hline 80-82 & 0.86 & 0.947 & 12.17 & 0.17 & 0.007 & 20.351 & 1.590 & 0.063 & 10.01 & 2.15 & 5.08 & -11.01 & 14.9 & 840.2 & 56.3 \\
\hline $82-84$ & 0.90 & 0.995 & 12.16 & 0.17 & 0.007 & 18.801 & 1.686 & 0.070 & 10.26 & 1.89 & 5.14 & -11.24 & 13.0 & 689.1 & 53.0 \\
\hline 84-86 & 0.94 & 1.031 & 12.19 & 0.17 & 0.007 & 23.805 & 1.798 & 0.072 & 9.88 & 2.31 & 4.90 & -11.20 & 15.4 & 849.5 & 55.0 \\
\hline 86-88 & 0.91 & 0.996 & 12.22 & 0.18 & 0.007 & 22.619 & 1.799 & 0.071 & 9.95 & 2.27 & 5.03 & -11.18 & 14.7 & 823.9 & 56.2 \\
\hline $88-90$ & 0.93 & 1.018 & 12.26 & 0.19 & 0.008 & 25.655 & 1.950 & 0.084 & 9.74 & 2.52 & 4.69 & -10.95 & 15.4 & 787.4 & 51.3 \\
\hline $90-92$ & 0.82 & 0.901 & 12.23 & 0.18 & 0.008 & 20.721 & 1.631 & 0.070 & 9.94 & 2.3 & 4.88 & -11.12 & 14.8 & 769.9 & 51.9 \\
\hline $92-94$ & 0.91 & 0.996 & 12.22 & 0.18 & 0.007 & 20.212 & 1.767 & 0.071 & 10.19 & 2.03 & 4.86 & -11.00 & 13.3 & 735.5 & 55.1 \\
\hline $94-96$ & 0.91 & 1.004 & 12.23 & 0.17 & 0.007 & 22.689 & 1.752 & 0.072 & 9.97 & 2.26 & 5.20 & -11.11 & 15.1 & 819.2 & 54.2 \\
\hline $96-98$ & 0.92 & 1.015 & 12.17 & 0.17 & 0.007 & 24.561 & 1.761 & 0.070 & 9.75 & 2.42 & 5.34 & -10.84 & 16.3 & 905.6 & 55.7 \\
\hline 98-100 & 0.84 & 0.921 & 12.16 & 0.17 & 0.007 & 18.694 & 1.570 & 0.065 & 10.13 & 2.03 & 5.59 & -10.90 & 13.9 & 737.8 & 53.1 \\
\hline $100-102$ & 0.84 & 0.924 & 12.12 & 0.16 & 0.007 & 20.597 & 1.515 & 0.064 & 9.89 & 2.23 & 5.66 & -10.98 & 15.9 & 828.3 & 52.2 \\
\hline $102-104$ & 0.94 & 1.035 & 12.16 & 0.15 & 0.006 & 21.427 & 1.542 & 0.066 & 10.09 & 2.07 & 5.69 & -10.94 & 16.2 & 840.4 & 51.9 \\
\hline 104-106 & 0.98 & 1.080 & 12.12 & 0.15 & 0.006 & 21.269 & 1.571 & 0.064 & 10.15 & 1.97 & 5.93 & -10.66 & 15.8 & 863.1 & 54.6 \\
\hline 106-108 & 0.96 & 1.052 & 12.14 & 0.15 & 0.005 & 19.570 & 1.541 & 0.057 & 10.29 & 1.86 & 5.86 & -11.20 & 14.8 & 892.7 & 60.3 \\
\hline $108-110$ & 1.03 & 1.138 & 12.13 & 0.15 & 0.005 & 23.666 & 1.684 & 0.061 & 10.05 & 2.08 & 5.77 & -10.78 & 16.4 & 996.9 & 60.8 \\
\hline $110-112$ & 0.98 & 1.083 & 12.15 & 0.15 & 0.006 & 22.637 & 1.630 & 0.064 & 10.06 & 2.09 & 5.48 & -10.70 & 16.2 & 918.8 & 56.7 \\
\hline $112-114$ & 0.94 & 1.032 & 12.18 & 0.16 & 0.006 & 21.973 & 1.609 & 0.061 & 10.05 & 2.13 & 5.33 & -10.96 & 15.9 & 924.5 & 58.0 \\
\hline $114-116$ & 0.90 & 0.988 & 12.18 & 0.16 & 0.006 & 21.348 & 1.542 & 0.058 & 10.01 & 2.16 & 5.28 & -10.87 & 16.2 & 958.9 & 59.4 \\
\hline $116-118$ & 0.95 & 1.040 & 12.22 & 0.16 & 0.006 & 22.881 & 1.648 & 0.058 & 10.02 & 2.2 & 5.21 & -10.71 & 16.2 & 1016.2 & 62.8 \\
\hline $118-120$ & 0.94 & 1.033 & 12.21 & 0.16 & 0.006 & 22.406 & 1.600 & 0.063 & 10.03 & 2.17 & 5.27 & -10.71 & 16.3 & 923.3 & 56.5 \\
\hline
\end{tabular}




\begin{tabular}{|c|c|c|c|c|c|c|c|c|c|c|c|c|c|c|c|}
\hline Depth & $\begin{array}{c}\text { Bulk } \\
\text { Density } \\
\text { (dry) }\end{array}$ & MAR* & $\% \mathrm{C}$ & $\% \mathrm{~N}$ & $\% \mathrm{P}$ & $\begin{array}{l}\text { MAR- } \\
\text { OC** }\end{array}$ & $\begin{array}{c}\text { MAR- } \\
\mathrm{N}^{* *}\end{array}$ & $\begin{array}{c}\text { MAR- } \\
\mathrm{P}^{* *}\end{array}$ & $\begin{array}{c}\text { Total } \\
\text { IC } \\
(\%)\end{array}$ & $\begin{array}{c}\text { Total } \\
\text { OC } \\
(\%) \\
\end{array}$ & $\begin{array}{c}\delta^{15} \mathrm{~N} \\
\text { (\%o AIR) }\end{array}$ & $\begin{array}{c}\delta^{13} \mathrm{C} \\
\text { (\% PDB) }\end{array}$ & $\mathrm{C} / \mathrm{N}$ & $\mathrm{C} / \mathrm{P}$ & $\mathrm{N} / \mathrm{P}$ \\
\hline $120-122$ & 0.88 & 0.973 & 12.19 & 0.16 & 0.007 & 19.856 & 1.543 & 0.065 & 10.15 & 2.04 & 5.23 & -10.85 & 15.0 & 787.6 & 52.4 \\
\hline $122-124$ & 0.88 & 0.971 & 12.18 & 0.16 & 0.007 & 19.710 & 1.553 & 0.068 & 10.16 & 2.03 & 5.21 & -10.87 & 14.8 & 746.5 & 50.4 \\
\hline $124-126$ & 1.01 & 1.110 & 12.19 & 0.16 & 0.006 & 23.982 & 1.788 & 0.070 & 10.03 & 2.16 & 5.23 & -11.27 & 15.7 & 885.2 & 56.6 \\
\hline $126-128$ & 0.88 & 0.967 & 12.25 & 0.17 & 0.006 & 22.340 & 1.630 & 0.063 & 9.94 & 2.31 & 5.20 & -10.82 & 16.0 & 922.2 & 57.7 \\
\hline $128-130$ & 0.94 & 1.029 & 12.23 & 0.17 & 0.006 & 22.421 & 1.702 & 0.064 & 10.05 & 2.18 & 5.19 & -10.88 & 15.4 & 900.8 & 58.6 \\
\hline 130-132 & 0.86 & 0.944 & 12.25 & 0.17 & 0.007 & 19.642 & 1.577 & 0.063 & 10.17 & 2.08 & 5.22 & -10.68 & 14.5 & 802.7 & 55.2 \\
\hline $132-134$ & 1.02 & 1.127 & 12.17 & 0.16 & 0.007 & 22.764 & 1.764 & 0.074 & 10.15 & 2.02 & 5.24 & -10.96 & 15.1 & 799.0 & 53.1 \\
\hline 134-136 & 0.88 & 0.971 & 12.20 & 0.16 & 0.007 & 19.329 & 1.510 & 0.065 & 10.21 & 1.99 & 5.26 & -11.03 & 14.9 & 772.4 & 51.7 \\
\hline 136-138 & 0.91 & 1.004 & 12.17 & 0.16 & 0.007 & 20.291 & 1.617 & 0.065 & 10.15 & 2.02 & 5.36 & -11.04 & 14.6 & 801.5 & 54.8 \\
\hline $138-140$ & 0.78 & 0.858 & 12.18 & 0.16 & 0.006 & 19.215 & 1.355 & 0.053 & 9.93 & 2.24 & 5.55 & -10.64 & 16.5 & 944.7 & 57.1 \\
\hline $140-142$ & 0.83 & 0.912 & 12.20 & 0.17 & 0.006 & 21.612 & 1.523 & 0.058 & 9.83 & 2.37 & 5.28 & -10.53 & 16.6 & 956.5 & 57.8 \\
\hline $142-144$ & 0.81 & 0.892 & 11.99 & 0.11 & 0.005 & 12.130 & 0.950 & 0.043 & 10.63 & 1.36 & 5.41 & -10.67 & 14.9 & 723.1 & 48.5 \\
\hline $144-146$ & 0.78 & 0.863 & 11.66 & 0.09 & 0.004 & 7.936 & 0.738 & 0.035 & 10.74 & 0.92 & 5.32 & -10.79 & 12.6 & 582.2 & 46.4 \\
\hline $146-148$ & 0.78 & 0.853 & 11.89 & 0.09 & 0.004 & 10.661 & 0.738 & 0.036 & 10.64 & 1.25 & 5.06 & -10.62 & 16.9 & 773.7 & 45.9 \\
\hline $148-150$ & 0.88 & 0.970 & 12.03 & 0.13 & 0.004 & 15.620 & 1.300 & 0.042 & 10.43 & 1.61 & 5.02 & -10.58 & 14.0 & 967.8 & 69.0 \\
\hline $150-152$ & 0.67 & 0.739 & 11.35 & 0.05 & 0.003 & 5.393 & 0.395 & 0.025 & 10.62 & 0.73 & 5.72 & -11.14 & 15.9 & 552.6 & 34.7 \\
\hline $152-154$ & 0.81 & 0.895 & 12.03 & 0.13 & 0.006 & 13.870 & 1.123 & 0.050 & 10.48 & 1.55 & 5.35 & -10.73 & 14.4 & 713.6 & 49.5 \\
\hline $154-156$ & 0.97 & 1.070 & 11.96 & 0.13 & 0.005 & 45.480 & 1.380 & 0.058 & 7.71 & 4.25 & 5.65 & -10.50 & 38.4 & 2024.5 & 52.7 \\
\hline $156-158$ & 1.01 & 1.110 & 11.89 & 0.12 & 0.004 & 17.098 & 1.377 & 0.049 & 10.35 & 1.54 & 5.52 & -10.82 & 14.5 & 894.1 & 61.7 \\
\hline $158-160$ & 0.88 & 0.963 & 12.05 & 0.12 & 0.004 & 13.777 & 1.132 & 0.038 & 10.62 & 1.43 & 5.44 & -10.68 & 14.2 & 941.3 & 66.3 \\
\hline $160-162$ & 1.01 & 1.115 & 11.92 & 0.11 & 0.005 & 14.049 & 1.243 & 0.056 & 10.66 & 1.26 & 5.48 & -10.83 & 13.2 & 650.1 & 49.3 \\
\hline $162-164$ & 1.20 & 1.324 & 11.85 & 0.09 & 0.004 & 14.829 & 1.205 & 0.050 & 10.73 & 1.12 & 5.36 & -11.17 & 14.4 & 763.5 & 53.2 \\
\hline $\begin{array}{l}\text { 164-165 } \\
\text { core }\end{array}$ & 0.95 & 1.044 & 11.79 & 0.09 & 0.003 & 9.400 & 0.893 & 0.036 & 10.89 & 0.9 & 5.31 & -11.32 & 12.3 & 672.5 & 54.8 \\
\hline bottom & 0.69 & 0.756 & 11.93 & 0.10 & 0.005 & 9.599 & 0.782 & 0.035 & 10.66 & 1.27 & 5.21 & -11.30 & 14.3 & 712.4 & 49.8 \\
\hline
\end{tabular}

*MAR - Mass Accumulation Rate, expressed as g/cm²/yr

**MAR expressed as $\mathrm{mg} / \mathrm{cm}^{2} / \mathrm{yr}$ 
Appendix 8: Bob Allen Bank Core Geochemical Dataset

\begin{tabular}{|c|c|c|c|c|c|c|c|c|c|c|c|c|c|c|c|}
\hline Depth & $\begin{array}{c}\text { Bulk } \\
\text { Density } \\
\text { (dry) }\end{array}$ & MAR* & $\% \mathrm{C}$ & $\% \mathrm{~N}$ & $\% \mathrm{P}$ & $\begin{array}{l}\text { MAR- } \\
\text { OC** }\end{array}$ & $\begin{array}{c}\text { MAR- } \\
\mathrm{N}^{* *}\end{array}$ & $\begin{array}{c}\text { MAR- } \\
\mathrm{P}^{* *}\end{array}$ & $\begin{array}{c}\text { Total } \\
\text { IC (\%) }\end{array}$ & $\begin{array}{c}\text { Total } \\
\text { OC (\%) }\end{array}$ & $\begin{array}{c}\delta^{15} \mathrm{~N} \\
\text { (\%o AIR) }\end{array}$ & $\begin{array}{c}\delta^{13} \mathrm{C} \\
\text { (\% PDB) }\end{array}$ & $\mathrm{C} / \mathrm{N}$ & $\mathrm{C} / \mathrm{P}$ & $\mathrm{N} / \mathrm{P}$ \\
\hline $0-2$ & 0.56 & 0.224 & 12.19 & 0.22 & 0.007 & 5.620 & 0.493 & 0.016 & 9.68 & 2.51 & 3.89 & -11.19 & 13.3 & 1015.5 & 76.3 \\
\hline $2-4$ & 0.53 & 0.212 & 12.13 & 0.22 & 0.007 & 5.281 & 0.466 & 0.015 & 9.64 & 2.49 & 3.75 & -11.14 & 13.2 & 1008.2 & 76.3 \\
\hline $4-6$ & 0.7 & 0.28 & 12.29 & 0.22 & 0.007 & 6.823 & 0.616 & 0.020 & 9.85 & 2.44 & 4.21 & -10.94 & 12.9 & 986.3 & 76.3 \\
\hline $6-8$ & 0.71 & 0.284 & 12.25 & 0.22 & 0.007 & 6.780 & 0.625 & 0.020 & 9.86 & 2.39 & 3.87 & -10.72 & 12.7 & 966.3 & 76.3 \\
\hline $8-10$ & 0.64 & 0.256 & 12.26 & 0.21 & 0.006 & 6.063 & 0.538 & 0.015 & 9.90 & 2.37 & 4.35 & -10.69 & 13.2 & 1118.3 & 85.0 \\
\hline $10-12$ & 0.68 & 0.272 & 12.20 & 0.2 & 0.007 & 6.440 & 0.544 & 0.019 & 9.83 & 2.37 & 4.89 & -10.49 & 13.8 & 958.3 & 69.4 \\
\hline $12-14$ & 0.58 & 0.232 & 12.27 & 0.22 & 0.006 & 5.545 & 0.510 & 0.014 & 9.88 & 2.39 & 4.44 & -10.41 & 12.7 & 1128.6 & 89.0 \\
\hline $14-16$ & 0.62 & 0.248 & 12.24 & 0.19 & 0.006 & 5.464 & 0.471 & 0.015 & 10.03 & 2.20 & 5.05 & -10.60 & 13.5 & 1040.5 & 76.9 \\
\hline $16-18$ & 0.72 & 0.288 & 12.21 & 0.2 & 0.006 & 6.206 & 0.576 & 0.017 & 10.06 & 2.15 & 4.96 & -10.53 & 12.6 & 1017.5 & 81.0 \\
\hline $18-20$ & 0.89 & 0.356 & 12.25 & 0.17 & 0.006 & 7.312 & 0.605 & 0.021 & 10.19 & 2.05 & 4.58 & -10.56 & 14.1 & 970.0 & 68.8 \\
\hline $20-22$ & 0.73 & 0.292 & 12.39 & 0.2 & 0.005 & 6.751 & 0.584 & 0.015 & 10.07 & 2.31 & 4.91 & -10.27 & 13.5 & 1310.1 & 97.1 \\
\hline $22-24$ & 0.7 & 0.28 & 12.24 & 0.18 & 0.005 & 3.568 & 0.504 & 0.014 & 10.97 & 1.27 & 4.62 & -10.15 & 8.3 & 722.2 & 87.4 \\
\hline $24-26$ & 0.66 & 0.264 & 12.19 & 0.17 & 0.005 & 5.201 & 0.449 & 0.013 & 10.22 & 1.97 & 4.59 & -10.08 & 13.5 & 1116.3 & 82.6 \\
\hline $26-28$ & 0.68 & 0.272 & 12.21 & 0.18 & 0.005 & 5.611 & 0.490 & 0.014 & 10.14 & 2.06 & 4.04 & -9.73 & 13.4 & 1169.0 & 87.4 \\
\hline $28-30$ & 0.7 & 0.28 & 12.19 & 0.16 & 0.005 & 4.978 & 0.448 & 0.014 & 10.42 & 1.78 & 4.35 & -9.41 & 13.0 & 1007.4 & 77.7 \\
\hline $30-32$ & 0.71 & 0.284 & 12.18 & 0.18 & 0.006 & 5.675 & 0.511 & 0.017 & 10.18 & 2.00 & 4.10 & -9.69 & 13.0 & 943.6 & 72.9 \\
\hline $32-34$ & 0.81 & 0.324 & 12.26 & 0.19 & 0.006 & 6.890 & 0.616 & 0.019 & 10.14 & 2.13 & 4.34 & -9.65 & 13.1 & 1004.1 & 76.9 \\
\hline $34-36$ & 0.71 & 0.284 & 12.25 & 0.19 & 0.006 & 6.116 & 0.540 & 0.017 & 10.10 & 2.15 & 3.87 & -9.45 & 13.2 & 1017.0 & 76.9 \\
\hline $36-38$ & 0.71 & 0.284 & 12.19 & 0.19 & 0.006 & 5.914 & 0.540 & 0.017 & 10.10 & 2.08 & 4.03 & -9.60 & 12.8 & 983.3 & 76.9 \\
\hline $38-40$ & 0.69 & 0.276 & 12.25 & 0.2 & 0.006 & 6.062 & 0.552 & 0.017 & 10.05 & 2.20 & 3.55 & -9.51 & 12.8 & 1037.3 & 81.0 \\
\hline $40-42$ & 0.75 & 0.3 & 12.26 & 0.19 & 0.006 & 6.634 & 0.570 & 0.018 & 10.05 & 2.21 & 3.73 & -9.44 & 13.6 & 1044.2 & 76.9 \\
\hline $42-44$ & 0.76 & 0.304 & 12.22 & 0.18 & 0.006 & 6.557 & 0.547 & 0.018 & 10.06 & 2.16 & 3.78 & -9.39 & 14.0 & 1018.6 & 72.9 \\
\hline $44-46$ & 0.71 & 0.284 & 12.27 & 0.19 & 0.006 & 6.338 & 0.540 & 0.017 & 10.04 & 2.23 & 3.39 & -9.31 & 13.7 & 1053.9 & 76.9 \\
\hline $46-48$ & 0.67 & 0.268 & 12.38 & 0.21 & 0.006 & 5.667 & 0.563 & 0.016 & 10.27 & 2.11 & 3.56 & -9.27 & 11.7 & 998.5 & 85.0 \\
\hline $48-50$ & 0.64 & 0.256 & 12.22 & 0.17 & 0.006 & 6.036 & 0.435 & 0.015 & 9.86 & 2.36 & 3.86 & -9.48 & 16.2 & 1113.4 & 68.8 \\
\hline $50-52$ & 0.79 & 0.316 & 12.20 & 0.18 & 0.006 & 5.314 & 0.569 & 0.019 & 10.52 & 1.68 & 3.80 & -9.50 & 10.9 & 794.1 & 72.9 \\
\hline $52-54$ & 0.76 & 0.304 & 12.20 & 0.17 & 0.006 & 4.897 & 0.517 & 0.018 & 10.58 & 1.61 & 4.09 & -9.57 & 11.1 & 760.6 & 68.8 \\
\hline $54-56$ & 0.77 & 0.308 & 12.23 & 0.18 & 0.007 & 4.601 & 0.554 & 0.022 & 10.73 & 1.49 & 4.29 & -9.63 & 9.7 & 604.7 & 62.4 \\
\hline $56-58$ & 0.69 & 0.276 & 12.20 & 0.19 & 0.007 & 4.445 & 0.524 & 0.019 & 10.59 & 1.61 & 3.87 & -9.56 & 9.9 & 651.9 & 65.9 \\
\hline
\end{tabular}


Bulk

Density

\begin{tabular}{|c|c|c|c|c|c|c|c|c|c|c|c|c|c|c|c|}
\hline Depth & $\begin{array}{l}\text { Density } \\
\text { (dry) }\end{array}$ & MAR* & $\% \mathrm{C}$ & $\% \mathrm{~N}$ & $\% \mathrm{P}$ & $\begin{array}{l}\text { MAR- } \\
\text { OC** }\end{array}$ & $\begin{array}{l}\text { MAR- } \\
\mathrm{N}^{* *}\end{array}$ & $\begin{array}{l}\text { MAR- } \\
\mathrm{P}^{* *}\end{array}$ & $\begin{array}{c}\text { Total } \\
\text { IC (\%) }\end{array}$ & $\begin{array}{c}\text { Total } \\
\text { OC (\%) }\end{array}$ & $\begin{array}{c}\delta^{1 \mathrm{~N}} \\
\text { (\%o AIR) }\end{array}$ & $\begin{array}{c}\delta^{10} \mathrm{C} \\
\text { (\%o PDB) }\end{array}$ & $\mathrm{C} / \mathrm{N}$ & $\mathrm{C} / \mathrm{P}$ & N/P \\
\hline $58-60$ & 0.68 & 0.272 & 12.33 & 0.21 & 0.007 & 6.534 & 0.571 & 0.019 & 9.93 & 2.40 & 4.26 & -9.56 & 13.3 & 972.3 & 72.9 \\
\hline $60-62$ & 0.73 & 0.292 & 12.26 & 0.2 & 0.007 & 6.857 & 0.584 & 0.020 & 9.91 & 2.35 & 4.18 & -9.61 & 13.7 & 950.6 & 69.4 \\
\hline $62-64$ & 0.91 & 0.364 & 12.13 & 0.17 & 0.007 & 7.253 & 0.619 & 0.025 & 10.14 & 1.99 & 4.12 & -10.01 & 13.7 & 806.5 & 59.0 \\
\hline 64-66 & 0.81 & 0.324 & 12.22 & 0.19 & 0.007 & 6.898 & 0.616 & 0.023 & 10.09 & 2.13 & 3.94 & -9.83 & 13.1 & 861.7 & 65.9 \\
\hline $66-68$ & 0.78 & 0.312 & 12.17 & 0.18 & 0.007 & 6.370 & 0.562 & 0.022 & 10.13 & 2.04 & 4.14 & -9.95 & 13.2 & 826.3 & 62.4 \\
\hline $68-70$ & 0.75 & 0.3 & 12.37 & 0.19 & 0.006 & 6.816 & 0.570 & 0.018 & 10.10 & 2.27 & 4.25 & -9.42 & 14.0 & 1072.9 & 76.9 \\
\hline $70-72$ & 0.72 & 0.288 & 12.43 & 0.2 & 0.006 & 6.857 & 0.576 & 0.017 & 10.05 & 2.38 & 4.07 & -9.20 & 13.9 & 1124.3 & 81.0 \\
\hline $72-74$ & 0.67 & 0.268 & 12.59 & 0.23 & 0.006 & 6.796 & 0.616 & 0.016 & 10.05 & 2.54 & 4.02 & -8.88 & 12.9 & 1197.5 & 93.1 \\
\hline $74-76$ & 0.75 & 0.3 & 12.63 & 0.23 & 0.006 & 7.271 & 0.690 & 0.018 & 10.21 & 2.42 & 4.07 & -8.59 & 12.3 & 1144.5 & 93.1 \\
\hline $76-78$ & 0.67 & 0.268 & 12.33 & 0.19 & 0.006 & 5.287 & 0.509 & 0.016 & 10.35 & 1.97 & 4.15 & -8.94 & 12.1 & 931.6 & 76.9 \\
\hline $78-80$ & 0.77 & 0.308 & 12.36 & 0.19 & 0.006 & 6.609 & 0.585 & 0.018 & 10.21 & 2.15 & 3.74 & -9.21 & 13.2 & 1013.2 & 76.9 \\
\hline $80-82$ & 0.65 & 0.26 & 12.36 & 0.18 & 0.006 & 5.459 & 0.468 & 0.016 & 10.26 & 2.10 & 3.73 & -9.40 & 13.6 & 991.6 & 72.9 \\
\hline $82-84$ & 0.79 & 0.316 & 12.44 & 0.2 & 0.005 & 7.116 & 0.632 & 0.016 & 10.19 & 2.25 & 3.39 & -9.25 & 13.1 & 1276.0 & 97.1 \\
\hline $84-86$ & 0.76 & 0.304 & 12.49 & 0.2 & 0.006 & 6.841 & 0.608 & 0.018 & 10.23 & 2.25 & 3.92 & -9.15 & 13.1 & 1062.6 & 81.0 \\
\hline $86-88$ & 0.86 & 0.344 & 12.46 & 0.21 & 0.006 & 7.849 & 0.722 & 0.021 & 10.18 & 2.28 & 4.41 & -9.15 & 12.7 & 1077.5 & 85.0 \\
\hline $88-90$ & 0.67 & 0.268 & 12.58 & 0.23 & 0.006 & 6.056 & 0.616 & 0.016 & 10.32 & 2.26 & 4.23 & -9.38 & 11.5 & 1067.0 & 93.1 \\
\hline $90-92$ & 0.69 & 0.276 & 12.56 & 0.23 & 0.006 & 6.993 & 0.635 & 0.017 & 10.03 & 2.53 & 4.75 & -9.16 & 12.9 & 1196.4 & 93.1 \\
\hline $92-94$ & 0.83 & 0.332 & 12.48 & 0.22 & 0.006 & 7.638 & 0.730 & 0.020 & 10.18 & 2.30 & 4.65 & -9.01 & 12.2 & 1086.4 & 89.0 \\
\hline $94-96$ & 0.8 & 0.32 & 12.54 & 0.22 & 0.006 & 8.344 & 0.704 & 0.019 & 9.93 & 2.61 & 4.14 & -9.04 & 13.8 & 1231.3 & 89.0 \\
\hline $96-98$ & 0.77 & 0.308 & 12.49 & 0.22 & 0.006 & 8.085 & 0.678 & 0.018 & 9.86 & 2.63 & 3.75 & -9.20 & 13.9 & 1239.6 & 89.0 \\
\hline $98-100$ & 0.71 & 0.284 & 12.52 & 0.22 & 0.005 & 6.163 & 0.625 & 0.014 & 10.35 & 2.17 & 3.96 & -9.11 & 11.5 & 1229.8 & 106.9 \\
\hline $100-102$ & 0.79 & 0.316 & 12.35 & 0.2 & 0.006 & 5.877 & 0.632 & 0.019 & 10.49 & 1.86 & 3.75 & -9.21 & 10.8 & 878.3 & 81.0 \\
\hline $102-104$ & 0.78 & 0.312 & 12.43 & 0.21 & 0.005 & 6.172 & 0.655 & 0.016 & 10.46 & 1.98 & 3.87 & -9.33 & 11.0 & 1120.9 & 102.0 \\
\hline $104-106$ & 0.83 & 0.332 & 12.52 & 0.22 & 0.005 & 6.887 & 0.730 & 0.017 & 10.44 & 2.07 & 3.79 & -9.32 & 11.0 & 1175.5 & 106.9 \\
\hline $106-108$ & 0.75 & 0.3 & 12.42 & 0.22 & 0.006 & 6.326 & 0.660 & 0.018 & 10.31 & 2.11 & 3.93 & -9.37 & 11.2 & 995.8 & 89.0 \\
\hline $108-110$ & 0.84 & 0.336 & 12.27 & 0.2 & 0.006 & 6.339 & 0.672 & 0.020 & 10.38 & 1.89 & 4.22 & -9.60 & 11.0 & 890.9 & 81.0 \\
\hline $110-112$ & 0.98 & 0.392 & 12.23 & 0.19 & 0.007 & 7.414 & 0.745 & 0.027 & 10.33 & 1.89 & 4.12 & -9.56 & 11.6 & 765.5 & 65.9 \\
\hline $112-114$ & 0.85 & 0.34 & 12.27 & 0.19 & 0.007 & 6.208 & 0.646 & 0.024 & 10.44 & 1.83 & 4.00 & -9.42 & 11.2 & 739.1 & 65.9 \\
\hline $114-116$ & 0.93 & 0.372 & 12.29 & 0.17 & 0.006 & 6.350 & 0.632 & 0.022 & 10.58 & 1.71 & 3.69 & -9.27 & 11.7 & 806.1 & 68.8 \\
\hline 116-118 & 0.82 & 0.328 & 12.23 & 0.16 & 0.006 & 5.352 & 0.525 & 0.020 & 10.60 & 1.63 & 3.92 & -9.41 & 11.9 & 770.5 & 64.8 \\
\hline $118-120$ & 0.87 & 0.348 & 12.17 & 0.16 & 0.006 & 6.905 & 0.557 & 0.021 & 10.19 & 1.98 & 3.98 & -9.74 & 14.5 & 937.0 & 64.8 \\
\hline
\end{tabular}


Bulk

Density $\quad$ MAR- MAR- MAR- Total Total $\delta^{15} \mathrm{~N} \quad \delta^{13} \mathrm{C}$

\begin{tabular}{|c|c|c|c|c|c|c|c|c|c|c|c|c|c|c|c|}
\hline Depth & (dry) & MAR* & $\% \mathrm{C}$ & $\% \mathrm{~N}$ & $\% \mathrm{P}$ & $\mathrm{OC}^{* *}$ & $\mathrm{~N}^{* *}$ & $\mathrm{P}^{* *}$ & IC (\%) & OC (\%) & (\%o AIR) & (\% PDB) & $\mathrm{C} / \mathrm{N}$ & $\mathrm{C} / \mathrm{P}$ & N/P \\
\hline $120-122$ & 0.98 & 0.392 & 12.02 & 0.15 & 0.009 & 5.172 & 0.588 & 0.035 & 10.70 & 1.32 & 3.84 & -10.89 & 10.3 & 415.4 & 40.5 \\
\hline $122-124$ & 0.98 & 0.392 & 11.99 & 0.13 & 0.008 & 4.216 & 0.510 & 0.031 & 10.92 & 1.08 & 3.95 & -10.94 & 9.7 & 380.9 & 39.5 \\
\hline $124-126$ & 1 & 0.4 & 11.98 & 0.14 & 0.005 & 4.623 & 0.560 & 0.020 & 10.82 & 1.16 & 4.56 & -10.23 & 9.6 & 654.9 & 68.0 \\
\hline $126-128$ & 1 & 0.4 & 11.91 & 0.12 & 0.004 & 3.175 & 0.480 & 0.016 & 11.11 & 0.79 & 4.62 & -10.59 & 7.7 & 562.2 & 72.9 \\
\hline $128-130$ & 0.97 & 0.388 & 12.01 & 0.12 & 0.005 & 3.524 & 0.466 & 0.019 & 11.10 & 0.91 & 4.52 & -10.50 & 8.8 & 514.7 & 58.3 \\
\hline 130-132 & 0.85 & 0.34 & 12.05 & 0.14 & 0.006 & 4.099 & 0.476 & 0.020 & 10.85 & 1.21 & 4.54 & -10.50 & 10.0 & 569.3 & 56.7 \\
\hline $132-134$ & 0.99 & 0.396 & 12.09 & 0.15 & 0.006 & 5.904 & 0.594 & 0.024 & 10.60 & 1.49 & 4.20 & -10.66 & 11.6 & 704.0 & 60.7 \\
\hline $134-136$ & 1.04 & 0.416 & 12.13 & 0.15 & 0.006 & 6.551 & 0.624 & 0.025 & 10.55 & 1.57 & 4.33 & -10.82 & 12.2 & 743.6 & 60.7 \\
\hline 136-138 & 0.97 & 0.388 & 12.17 & 0.17 & 0.005 & 6.400 & 0.660 & 0.019 & 10.52 & 1.65 & 4.35 & -10.65 & 11.3 & 934.7 & 82.6 \\
\hline $138-140$ & 1.06 & 0.424 & 12.08 & 0.16 & 0.005 & 6.613 & 0.678 & 0.021 & 10.52 & 1.56 & 4.36 & -10.84 & 11.4 & 883.8 & 77.7 \\
\hline $140-142$ & 0.94 & 0.376 & 12.03 & 0.16 & 0.006 & 5.413 & 0.602 & 0.023 & 10.59 & 1.44 & 4.18 & -10.92 & 10.5 & 679.8 & 64.8 \\
\hline $142-144$ & 0.99 & 0.396 & 12.08 & 0.15 & 0.005 & 5.265 & 0.594 & 0.020 & 10.75 & 1.33 & 4.72 & -11.15 & 10.3 & 753.4 & 72.9 \\
\hline $144-146$ & 0.88 & 0.352 & 12.05 & 0.14 & 0.005 & 3.812 & 0.493 & 0.018 & 10.97 & 1.08 & 4.66 & -10.79 & 9.0 & 613.6 & 68.0 \\
\hline $146-148$ & 1.16 & 0.464 & 12.06 & 0.13 & 0.005 & 5.792 & 0.603 & 0.023 & 10.81 & 1.25 & 4.62 & -11.18 & 11.2 & 707.4 & 63.1 \\
\hline $148-150$ & 1.05 & 0.42 & 12.13 & 0.16 & 0.005 & 5.783 & 0.672 & 0.021 & 10.75 & 1.38 & 4.44 & -10.85 & 10.0 & 780.3 & 77.7 \\
\hline $150-152$ & 0.92 & 0.368 & 12.11 & 0.14 & 0.005 & 4.855 & 0.515 & 0.018 & 10.79 & 1.32 & 4.77 & -12.06 & 11.0 & 747.6 & 68.0 \\
\hline $152-154$ & 0.91 & 0.364 & 12.11 & 0.14 & 0.005 & 4.374 & 0.510 & 0.018 & 10.91 & 1.20 & 4.13 & -11.40 & 10.0 & 680.9 & 68.0 \\
\hline $154-156$ & 0.97 & 0.388 & 12.20 & 0.15 & 0.004 & 5.812 & 0.582 & 0.016 & 10.71 & 1.50 & 4.23 & -11.31 & 11.6 & 1061.0 & 91.1 \\
\hline $156-158$ & 0.91 & 0.364 & 12.17 & 0.15 & 0.005 & 5.245 & 0.546 & 0.018 & 10.72 & 1.44 & 4.04 & -11.65 & 11.2 & 816.6 & 72.9 \\
\hline 158-160 & 0.86 & 0.344 & 12.17 & 0.16 & 0.005 & 4.611 & 0.550 & 0.017 & 10.83 & 1.34 & 4.43 & -12.55 & 9.8 & 759.5 & 77.7 \\
\hline $160-162$ & 0.95 & 0.38 & 12.13 & 0.16 & 0.005 & 5.271 & 0.608 & 0.019 & 10.74 & 1.39 & 3.95 & -12.48 & 10.1 & 786.1 & 77.7 \\
\hline $162-164$ & 0.74 & 0.296 & 12.13 & 0.16 & 0.006 & 4.069 & 0.474 & 0.018 & 10.75 & 1.37 & 4.31 & -12.93 & 10.0 & 649.2 & 64.8 \\
\hline $164-166$ & 0.76 & 0.304 & 12.15 & 0.17 & 0.005 & 5.165 & 0.517 & 0.015 & 10.45 & 1.70 & 4.01 & -13.78 & 11.7 & 962.8 & 82.6 \\
\hline 166-168 & 0.75 & 0.3 & 12.39 & 0.19 & 0.005 & 6.697 & 0.570 & 0.015 & 10.16 & 2.23 & 4.19 & -15.15 & 13.7 & 1265.0 & 92.3 \\
\hline $168-170$ & 0.73 & 0.292 & 12.23 & 0.16 & 0.004 & 6.645 & 0.467 & 0.012 & 9.95 & 2.28 & 3.85 & -15.47 & 16.6 & 1612.0 & 97.1 \\
\hline $170-172$ & 0.62 & 0.248 & 12.70 & 0.22 & 0.005 & 7.368 & 0.546 & 0.012 & 9.73 & 2.97 & 3.78 & -17.51 & 15.8 & 1683.6 & 106.9 \\
\hline $172-174$ & 0.24 & 0.096 & 24.96 & 1.15 & 0.012 & 19.186 & 1.104 & 0.012 & 4.97 & 19.99 & 4.78 & -23.69 & 20.3 & 4718.8 & 232.7 \\
\hline $174-176$ & 0.27 & 0.108 & 22.94 & 0.99 & 0.011 & 17.831 & 1.069 & 0.012 & 6.43 & 16.51 & & -24.01 & 19.5 & 4252.6 & 218.6 \\
\hline $176-178$ & 0.35 & 0.14 & 19.49 & 0.54 & 0.008 & 15.590 & 0.756 & 0.011 & 8.36 & 11.14 & 3.77 & -24.03 & 24.1 & 3943.9 & 163.9 \\
\hline 178-180 & 0.54 & 0.216 & 14.79 & 0.34 & 0.006 & 11.187 & 0.734 & 0.013 & 9.61 & 5.18 & 3.83 & -23.06 & 17.8 & 2445.8 & 137.6 \\
\hline 180-182 & 0.4 & 0.16 & 15.51 & 0.32 & 0.006 & 9.238 & 0.512 & 0.010 & 9.73 & 5.77 & 3.67 & -24.02 & 21.0 & 2726.5 & 129.5 \\
\hline
\end{tabular}




\begin{tabular}{|c|c|c|c|c|c|c|c|c|c|c|c|c|c|c|c|}
\hline Depth & $\begin{array}{l}\text { Bulk } \\
\text { Density } \\
\text { (dry) }\end{array}$ & MAR* & $\% \mathrm{C}$ & $\% \mathrm{~N}$ & $\% \mathrm{P}$ & $\begin{array}{l}\text { MAR- } \\
\text { OC** }\end{array}$ & $\begin{array}{c}\text { MAR- } \\
\mathrm{N}^{* *}\end{array}$ & $\begin{array}{c}\text { MAR- } \\
\mathrm{P}^{* *}\end{array}$ & $\begin{array}{c}\text { Total } \\
\text { IC (\%) }\end{array}$ & $\begin{array}{c}\text { Total } \\
\text { OC (\%) }\end{array}$ & $\begin{array}{c}\delta^{15} \mathrm{~N} \\
(\% \text { AIR) }\end{array}$ & $\begin{array}{c}\delta^{13} \mathrm{C} \\
\text { (\% } \mathrm{PDB})\end{array}$ & $\mathrm{C} / \mathrm{N}$ & $\mathrm{C} / \mathrm{P}$ & N/P \\
\hline 182-184 & 0.52 & 0.208 & 15.46 & 0.46 & 0.013 & 13.585 & 0.957 & 0.027 & 8.93 & 6.53 & 3.58 & -23.10 & 16.6 & 1423.5 & 85.9 \\
\hline 184-186 & 0.39 & 0.156 & 16.19 & 0.39 & 0.010 & 10.977 & 0.608 & 0.016 & 9.16 & 7.04 & 3.47 & -23.23 & 21.0 & 1993.6 & 94.7 \\
\hline 186-188 & 0.71 & 0.284 & 14.28 & 0.29 & 0.010 & 14.049 & 0.824 & 0.028 & 9.33 & 4.95 & 3.54 & -21.43 & 19.9 & 1401.6 & 70.4 \\
\hline 188-190 & 0.62 & 0.248 & 15.20 & 0.42 & 0.013 & 16.183 & 1.042 & 0.032 & 8.67 & 6.53 & 3.24 & -22.90 & 18.1 & 1422.2 & 78.5 \\
\hline 190-192 & 0.8 & 0.32 & 13.14 & 0.28 & 0.015 & 14.315 & 0.896 & 0.048 & 8.67 & 4.47 & 3.59 & -20.04 & 18.6 & 845.0 & 45.3 \\
\hline $\begin{array}{l}192-193 \\
193-\end{array}$ & 1.12 & 0.448 & 13.26 & 0.41 & 0.033 & 32.378 & 1.837 & 0.148 & 6.03 & 7.23 & 4.17 & -20.90 & 20.6 & 620.5 & 30.2 \\
\hline bottom & 0.8 & 0.32 & 11.95 & 0.25 & 0.014 & 11.469 & 0.800 & 0.045 & 8.36 & 3.58 & 4.22 & -17.14 & 16.7 & 725.4 & 43.4 \\
\hline
\end{tabular}

*MAR - Mass Accumulation Rate, expressed as $\mathrm{g} / \mathrm{cm}^{2} / \mathrm{yr}$

**MAR expressed as $\mathrm{mg} / \mathrm{cm}^{2} / \mathrm{yr}$ 
Appendix 9: Ninemile Bank Core Geochemical Dataset

\begin{tabular}{|c|c|c|c|c|c|c|c|c|c|c|c|c|c|c|c|}
\hline Depth & $\begin{array}{c}\text { Bulk } \\
\text { Density } \\
\text { (dry) }\end{array}$ & MAR* & $\% \mathrm{C}$ & $\% \mathrm{~N}$ & $\% \mathrm{P}$ & $\begin{array}{l}\text { MAR- } \\
\text { OC** }\end{array}$ & $\begin{array}{c}\text { MAR- } \\
\mathrm{N}^{* *}\end{array}$ & $\begin{array}{l}\text { MAR- } \\
\mathrm{P}^{* *}\end{array}$ & $\begin{array}{c}\text { Total IC } \\
(\%)\end{array}$ & $\begin{array}{c}\text { Total } \\
\text { OC (\%) }\end{array}$ & $\begin{array}{c}\delta^{15} \mathrm{~N} \\
\text { (\%o AIR) }\end{array}$ & $\begin{array}{c}\delta^{13} \mathrm{C} \\
\text { (\%о PDB) }\end{array}$ & $\mathrm{C} / \mathrm{N}$ & $\mathrm{C} / \mathrm{P}$ & N/P \\
\hline $0-2$ & 0.458 & 0.229 & 12.05 & 0.39 & 0.029 & 8.115 & 0.888 & 0.067 & 8.51 & 3.55 & 1.60 & -13.50 & 10.7 & 312.9 & 29.3 \\
\hline $2-4$ & 0.576 & 0.288 & 12.02 & 0.35 & 0.032 & 8.799 & 1.005 & 0.092 & 8.97 & 3.05 & 1.60 & -13.47 & 10.2 & 246.4 & 24.1 \\
\hline 4-6 & 0.579 & 0.290 & 12.33 & 0.40 & 0.031 & 10.448 & 1.161 & 0.090 & 8.72 & 3.61 & 1.71 & -13.70 & 10.5 & 298.8 & 28.4 \\
\hline $6-8$ & 0.722 & 0.361 & 12.63 & 0.42 & 0.027 & 14.380 & 1.515 & 0.099 & 8.65 & 3.99 & 1.49 & -13.42 & 11.1 & 377.0 & 34.0 \\
\hline $8-10$ & 0.705 & 0.353 & 12.67 & 0.40 & 0.020 & 11.697 & 1.397 & 0.071 & 9.36 & 3.32 & 1.40 & -11.74 & 9.8 & 423.0 & 43.3 \\
\hline $10-12$ & 0.539 & 0.270 & 12.49 & 0.39 & 0.020 & & 1.052 & 0.054 & & & 1.48 & -11.68 & & & 42.9 \\
\hline $12-14$ & 0.624 & 0.312 & 12.44 & 0.38 & 0.022 & 11.177 & 1.175 & 0.068 & 8.86 & 3.59 & 1.71 & -11.60 & 11.1 & 421.8 & 38.0 \\
\hline $14-16$ & 0.466 & 0.233 & 12.24 & 0.37 & 0.019 & 8.416 & 0.852 & 0.045 & 8.63 & 3.61 & 1.71 & -11.66 & 11.5 & 482.0 & 41.8 \\
\hline $16-18$ & 0.538 & 0.269 & 12.17 & 0.36 & 0.021 & 9.186 & 0.976 & 0.057 & 8.76 & 3.41 & 1.97 & -11.98 & 11.0 & 416.0 & 37.9 \\
\hline $18-20$ & 0.750 & 0.375 & 12.18 & 0.30 & 0.017 & 10.872 & 1.126 & 0.063 & 9.29 & 2.90 & 1.90 & -11.91 & 11.3 & 448.9 & 39.9 \\
\hline $20-22$ & 0.534 & 0.267 & 12.05 & 0.33 & 0.018 & 8.696 & 0.888 & 0.048 & 8.79 & 3.26 & 2.06 & -11.87 & 11.4 & 470.4 & 41.2 \\
\hline $22-24$ & 0.533 & 0.266 & 12.22 & 0.33 & 0.018 & 8.473 & 0.890 & 0.048 & 9.04 & 3.18 & 1.93 & -11.68 & 11.1 & 452.3 & 40.7 \\
\hline 24-26 & 0.507 & 0.253 & 12.34 & 0.35 & 0.018 & 9.453 & 0.895 & 0.044 & 8.61 & 3.73 & 1.82 & -11.34 & 12.3 & 549.8 & 44.6 \\
\hline $26-28$ & 0.552 & 0.276 & 12.27 & 0.34 & 0.017 & 9.512 & 0.943 & 0.046 & 8.82 & 3.45 & 1.94 & -11.41 & 11.8 & 533.8 & 45.4 \\
\hline 28-30 & 0.658 & 0.329 & 12.16 & 0.30 & 0.016 & 9.414 & 0.982 & 0.052 & 9.30 & 2.86 & 1.90 & -11.48 & 11.2 & 467.6 & 41.8 \\
\hline 30-32 & 0.706 & 0.353 & 12.11 & 0.27 & 0.013 & 9.711 & 0.951 & 0.045 & 9.36 & 2.75 & 1.88 & -11.62 & 11.9 & 552.0 & 46.3 \\
\hline 32-34 & 0.466 & 0.233 & 12.39 & 0.37 & 0.018 & 8.827 & 0.864 & 0.043 & 8.60 & 3.79 & 1.90 & -10.84 & 11.9 & 533.3 & 44.8 \\
\hline 34-36 & 0.504 & 0.252 & 12.39 & 0.37 & 0.018 & 9.249 & 0.921 & 0.046 & 8.72 & 3.67 & 2.00 & -11.01 & 11.7 & 519.4 & 44.3 \\
\hline 36-38 & 0.689 & 0.344 & 12.21 & 0.31 & 0.017 & 11.477 & 1.066 & 0.058 & 8.88 & 3.33 & 2.03 & -11.39 & 12.6 & 508.7 & 40.5 \\
\hline $38-40$ & 0.580 & 0.290 & 12.27 & 0.33 & 0.024 & 10.414 & 0.966 & 0.068 & 8.68 & 3.59 & 1.99 & -11.09 & 12.6 & 394.2 & 31.3 \\
\hline $40-42$ & 0.588 & 0.294 & 12.24 & 0.32 & 0.022 & 10.219 & 0.936 & 0.065 & 8.76 & 3.48 & 2.15 & -11.23 & 12.7 & 408.2 & 32.1 \\
\hline $42-44$ & 0.648 & 0.324 & 12.23 & 0.32 & 0.019 & 10.443 & 1.051 & 0.062 & 9.01 & 3.22 & 2.07 & -11.09 & 11.6 & 435.6 & 37.6 \\
\hline $44-46$ & 0.647 & 0.323 & 12.01 & 0.29 & 0.017 & 9.961 & 0.946 & 0.055 & 8.93 & 3.08 & 2.13 & -10.75 & 12.3 & 467.5 & 38.1 \\
\hline $46-48$ & 0.745 & 0.373 & 12.09 & 0.29 & 0.017 & 10.897 & 1.081 & 0.062 & 9.16 & 2.92 & 1.99 & -10.58 & 11.8 & 456.1 & 38.8 \\
\hline $48-50$ & 0.699 & 0.350 & 11.93 & 0.26 & 0.016 & 9.037 & 0.897 & 0.057 & 9.34 & 2.59 & 2.24 & -10.82 & 11.7 & 412.5 & 35.1 \\
\hline $50-52$ & 0.694 & 0.347 & 11.95 & 0.28 & 0.020 & 10.394 & 0.962 & 0.069 & 8.95 & 3.00 & 2.24 & -10.81 & 12.6 & 390.2 & 31.0 \\
\hline $52-54$ & 0.795 & 0.397 & 11.69 & 0.22 & 0.017 & 8.809 & 0.869 & 0.069 & 9.47 & 2.22 & 2.88 & -11.84 & 11.8 & 331.2 & 28.0 \\
\hline $54-56$ & 1.104 & 0.552 & 11.50 & 0.16 & 0.017 & 10.623 & 0.901 & 0.093 & 9.57 & 1.92 & 3.10 & -12.51 & 13.8 & 295.6 & 21.5 \\
\hline $56-58$ & 0.809 & 0.404 & 11.64 & 0.19 & 0.020 & 8.241 & 0.755 & 0.080 & 9.60 & 2.04 & 2.97 & -12.11 & 12.7 & 265.5 & 20.8 \\
\hline $58-60$ & 0.807 & 0.404 & 11.70 & 0.20 & 0.020 & 9.500 & 0.816 & 0.081 & 9.35 & 2.35 & 2.76 & -11.72 & 13.6 & 303.8 & 22.4 \\
\hline 60-62 & 0.777 & 0.389 & 11.70 & 0.20 & 0.019 & 9.003 & 0.790 & 0.073 & 9.39 & 2.32 & 2.69 & -11.88 & 13.3 & 319.2 & 24.0 \\
\hline $62-64$ & 0.683 & 0.341 & 11.85 & 0.24 & 0.017 & 8.524 & 0.820 & 0.058 & 9.35 & 2.50 & 2.48 & -11.12 & 12.1 & 381.6 & 31.5 \\
\hline
\end{tabular}


Bulk

Density

MAR- MAR- MAR- Total IC Total $\quad \delta^{15} \mathrm{~N} \quad \delta^{13} \mathrm{C}$

\begin{tabular}{|c|c|c|c|c|c|c|c|c|c|c|c|c|c|c|c|}
\hline Depth & (dry) & MAR* & $\% \mathrm{C}$ & $\% \mathrm{~N}$ & $\% \mathrm{P}$ & OC** & $\mathrm{N}^{* *}$ & $\mathrm{P}^{* *}$ & $(\%)$ & OC (\%) & (\%o AIR) & (\% PDB) & $\mathrm{C} / \mathrm{N}$ & $\mathrm{C} / \mathrm{P}$ & N/P \\
\hline $64-66$ & 0.776 & 0.388 & 11.92 & 0.24 & 0.014 & 10.050 & 0.915 & 0.054 & 9.33 & 2.59 & 2.14 & -10.76 & 12.8 & 483.2 & 37.7 \\
\hline $66-68$ & 0.763 & 0.382 & 11.89 & 0.25 & 0.016 & 10.751 & 0.951 & 0.059 & 9.07 & 2.82 & 2.23 & -11.16 & 13.2 & 467.5 & 35.4 \\
\hline $68-70$ & 0.721 & 0.360 & 11.99 & 0.27 & 0.019 & 11.307 & 0.985 & 0.067 & 8.86 & 3.14 & 2.19 & -10.89 & 13.4 & 437.0 & 32.6 \\
\hline $70-72$ & 0.645 & 0.323 & 11.99 & 0.28 & 0.019 & 9.293 & 0.909 & 0.063 & 9.11 & 2.88 & 2.15 & -10.94 & 11.9 & 382.8 & 32.1 \\
\hline $72-74$ & 0.817 & 0.409 & 11.71 & 0.22 & 0.014 & 9.335 & 0.881 & 0.056 & 9.43 & 2.29 & 2.40 & -11.48 & 12.4 & 427.5 & 34.6 \\
\hline $74-76$ & 0.696 & 0.348 & 11.88 & 0.23 & 0.018 & 9.367 & 0.795 & 0.064 & 9.19 & 2.69 & 2.27 & -11.19 & 13.8 & 379.3 & 27.6 \\
\hline 76-78 & 0.646 & 0.323 & 11.79 & 0.22 & 0.017 & 7.970 & 0.697 & 0.056 & 9.33 & 2.47 & 2.19 & -11.05 & 13.3 & 370.8 & 27.8 \\
\hline $78-80$ & 0.794 & 0.397 & 11.84 & 0.19 & 0.015 & 8.556 & 0.747 & 0.058 & 9.68 & 2.16 & 2.57 & -11.60 & 13.4 & 378.6 & 28.3 \\
\hline 80-82 & 0.791 & 0.396 & 11.74 & 0.22 & 0.019 & 9.535 & 0.865 & 0.075 & 9.33 & 2.41 & 2.54 & -11.73 & 12.9 & 329.3 & 25.6 \\
\hline 82-84 & 0.570 & 0.285 & 11.82 & 0.20 & 0.015 & 6.198 & 0.568 & 0.041 & 9.64 & 2.17 & 2.52 & -11.41 & 12.7 & 385.9 & 30.3 \\
\hline $84-86$ & 0.818 & 0.409 & 11.64 & 0.19 & 0.014 & 9.197 & 0.791 & 0.057 & 9.39 & 2.25 & 2.72 & -12.04 & 13.6 & 413.8 & 30.5 \\
\hline $86-88$ & 0.813 & 0.406 & 11.72 & 0.20 & 0.015 & 8.330 & 0.801 & 0.061 & 9.67 & 2.05 & 2.75 & -12.36 & 12.1 & 351.1 & 28.9 \\
\hline $88-90$ & 0.989 & 0.495 & 11.78 & 0.20 & 0.016 & 11.082 & 0.996 & 0.080 & 9.54 & 2.24 & 2.6 & -11.83 & 13.0 & 356.3 & 27.4 \\
\hline $90-92$ & 0.837 & 0.418 & 11.73 & 0.17 & 0.013 & 8.271 & 0.723 & 0.056 & 9.75 & 1.98 & 2.88 & -11.67 & 13.3 & 380.0 & 28.5 \\
\hline $92-94$ & 1.184 & 0.592 & 11.78 & 0.16 & 0.011 & 10.916 & 0.962 & 0.068 & 9.94 & 1.84 & 2.87 & -11.71 & 13.2 & 414.3 & 31.3 \\
\hline $94-96$ & 1.048 & 0.524 & 11.82 & 0.16 & & 9.808 & 0.831 & 0.000 & 9.95 & 1.87 & 2.64 & -11.28 & 13.8 & & \\
\hline $96-98$ & 0.740 & 0.370 & 11.84 & 0.20 & 0.012 & 8.419 & 0.736 & 0.04 & 9.56 & 2.28 & 2.6 & -11.67 & 13.3 & 474.0 & 35.5 \\
\hline $98-100$ & 1.015 & 0.507 & 12.10 & 0.26 & 0.019 & 14.482 & 1.307 & 0.095 & 9.25 & 2.85 & 2.69 & -11.02 & 12.9 & 392.3 & 30.3 \\
\hline $100-102$ & 0.950 & 0.475 & 11.81 & 0.22 & 0.021 & 12.004 & 1.036 & 0.100 & 9.29 & 2.53 & 3.01 & -11.84 & 13.5 & 311.5 & 23.0 \\
\hline $102-104$ & 1.270 & 0.635 & 11.70 & 0.13 & 0.011 & 0 & 0.8 & 0.069 & & & 3.1 & -12.51 & 0.0 & 0.0 & 27.4 \\
\hline $104-106$ & 1.540 & 0.770 & 11.65 & 0.11 & 0.012 & 8.312 & 0.882 & 0.092 & 10.57 & 1.08 & 3.31 & -12.84 & 11.0 & 232.5 & 21.2 \\
\hline $106-108$ & 1.555 & 0.777 & 11.69 & 0.13 & 0.011 & 9.695 & 0.986 & 0.083 & 10.44 & 1.25 & 3.26 & -13.25 & 11.5 & 300.0 & 26.1 \\
\hline $108-110$ & 1.448 & 0.724 & 11.74 & 0.11 & 0.011 & 7.304 & 0.766 & 0.081 & 10.73 & 1.01 & 3.03 & -12.74 & 11.1 & 231.6 & 20.8 \\
\hline $110-112$ & 1.633 & 0.817 & 11.69 & 0.10 & & 6.553 & 0.804 & 0.000 & 10.88 & 0.80 & 3.3 & -12.43 & 9.5 & & \\
\hline $112-114$ & 1.550 & 0.775 & 11.70 & 0.12 & 0.008 & 6.570 & 0.934 & 0.060 & 10.85 & 0.85 & 3.1 & -12.35 & 8.2 & 280.9 & 34.2 \\
\hline $114-116$ & 1.124 & 0.562 & 11.76 & 0.15 & 0.016 & 8.324 & 0.826 & 0.091 & 10.28 & 1.48 & 2.66 & -12.49 & 11.8 & 236.7 & 20.1 \\
\hline $116-118$ & 1.535 & 0.768 & 11.47 & 0.10 & 0.009 & 4.882 & 0.737 & 0.072 & 10.84 & 0.64 & 3.82 & -12.79 & 7.7 & 176.0 & 22.8 \\
\hline $118-120$ & 1.411 & 0.705 & 11.68 & 0.08 & 0.008 & 5.133 & 0.579 & 0.057 & 10.96 & 0.73 & 3.78 & -12.64 & 10.3 & 233.1 & 22.5 \\
\hline $120-122$ & 1.284 & 0.642 & 11.64 & 0.10 & 0.007 & 5.652 & 0.649 & 0.048 & 10.76 & 0.8 & 3.86 & -12.26 & 10.2 & 304.0 & 29.9 \\
\hline $122-124$ & 1.415 & 0.707 & 11.68 & 0.08 & 0.006 & 6.417 & 0.590 & 0.046 & 10.78 & 0.91 & 4.00 & -12.08 & 12.7 & 361.3 & 28.5 \\
\hline $124-126$ & 1.140 & 0.570 & 11.59 & 0.12 & 0.009 & 5.197 & 0.685 & 0.053 & 10.68 & 0.91 & 3.66 & -12.58 & 8.9 & 254.9 & 28.8 \\
\hline $126-128$ & 1.224 & 0.612 & 11.67 & 0.10 & 0.008 & 6.564 & 0.602 & 0.048 & 10.60 & 1.07 & 3.93 & -12.49 & 12.7 & 356.4 & 28.0 \\
\hline $128-130$ & 1.325 & 0.662 & 11.69 & 0.08 & 0.009 & 5.606 & 0.533 & 0.061 & 10.84 & 0.85 & 4.02 & -13.50 & 12.3 & 236.7 & 19.3 \\
\hline 130-132 & 0.941 & 0.471 & 11.61 & 0.10 & 0.009 & 5.077 & 0.459 & 0.043 & 10.53 & 1.08 & 3.77 & -12.99 & 12.9 & 304.0 & 23.5 \\
\hline
\end{tabular}


Bulk

Density

MAR- MAR- MAR- Total Total $\quad \delta^{15} \mathrm{~N} \quad \delta^{13} \mathrm{C}$

\begin{tabular}{|c|c|c|c|c|c|c|c|c|c|c|c|c|c|c|c|}
\hline Depth & (dry) & MAR* & $\% \mathrm{C}$ & $\% \mathrm{~N}$ & $\% \mathrm{P}$ & $\mathrm{OC}^{* *}$ & $\mathrm{~N}^{* *}$ & $\mathrm{P}^{* *}$ & IC (\%) & OC (\%) & (\% AIR) & (\% PDB) & $\mathrm{C} / \mathrm{N}$ & $\mathrm{C} / \mathrm{P}$ & N/P \\
\hline 132-134 & 1.065 & 0.532 & 11.63 & 0.10 & 0.009 & 6.331 & 0.523 & 0.045 & 10.44 & 1.19 & 3.80 & -12.75 & 14.1 & 360.9 & 25.6 \\
\hline 134-136 & 1.004 & 0.502 & 11.61 & 0.11 & 0.010 & 7.374 & 0.551 & 0.048 & 10.14 & 1.47 & 3.88 & -12.34 & 15.6 & 394.3 & 25.2 \\
\hline 136-138 & 1.299 & 0.650 & 11.68 & 0.10 & 0.009 & 7.878 & 0.661 & 0.060 & 10.47 & 1.21 & 4.12 & -12.14 & 13.9 & 341.6 & 24.6 \\
\hline $138-140$ & 1.161 & 0.580 & 11.58 & 0.09 & 0.008 & 4.762 & 0.549 & 0.044 & 10.76 & 0.82 & 3.89 & -13.02 & 10.1 & 280.9 & 27.8 \\
\hline $140-142$ & 1.020 & 0.510 & 11.64 & 0.09 & 0.007 & 5.153 & 0.484 & 0.036 & 10.63 & 1.01 & 3.85 & -12.57 & 12.4 & 374.8 & 30.1 \\
\hline $142-144$ & 0.929 & 0.465 & 11.73 & 0.10 & 0.009 & 6.075 & 0.477 & 0.040 & 10.42 & 1.31 & 3.89 & -12.27 & 14.9 & 389.0 & 26.2 \\
\hline $144-146$ & 1.152 & 0.576 & 11.65 & 0.10 & 0.008 & 7.015 & 0.568 & 0.049 & 10.43 & 1.22 & 3.84 & -12.60 & 14.4 & 370.8 & 25.7 \\
\hline $146-148$ & 1.210 & 0.605 & 11.63 & 0.10 & 0.008 & 7.758 & 0.590 & 0.046 & 10.35 & 1.28 & 4.01 & -11.98 & 15.4 & 434.7 & 28.3 \\
\hline 148-150 & 1.373 & 0.687 & 11.57 & 0.11 & 0.010 & 0.000 & 0.738 & 0.070 & & & 3.94 & -12.36 & & & 23.5 \\
\hline $150-152$ & 1.244 & 0.622 & 11.59 & 0.10 & 0.009 & 5.771 & 0.611 & 0.056 & 10.66 & 0.93 & 4.07 & -12.56 & 11.0 & 267.7 & 24.3 \\
\hline 152-154 & 0.736 & 0.368 & 11.77 & 0.09 & 0.005 & 4.002 & 0.346 & 0.019 & 10.68 & 1.09 & 3.80 & -11.31 & 13.5 & 534.3 & 39.6 \\
\hline 154-156 & 1.117 & 0.559 & 11.81 & 0.11 & 0.007 & 8.460 & 0.615 & 0.037 & 10.30 & 1.51 & 3.70 & -11.30 & 16.0 & 583.7 & 36.4 \\
\hline $156-158$ & 0.992 & 0.496 & 11.72 & 0.11 & 0.007 & 7.823 & 0.569 & 0.033 & 10.15 & 1.58 & 3.73 & -12.15 & 16.0 & 608.8 & 38.0 \\
\hline $158-160$ & 1.028 & 0.514 & 11.71 & 0.11 & 0.007 & 7.914 & 0.581 & 0.035 & 10.17 & 1.54 & 3.72 & -11.99 & 15.9 & 587.1 & 36.9 \\
\hline $160-162$ & 0.980 & 0.490 & 11.70 & 0.11 & 0.007 & 6.883 & 0.541 & 0.035 & 10.30 & 1.40 & 3.81 & -11.65 & 14.9 & 507.0 & 34.1 \\
\hline 162-164 & 0.930 & 0.465 & 11.60 & 0.10 & 0.005 & 5.386 & 0.452 & 0.024 & 10.44 & 1.16 & 3.84 & -11.93 & 13.9 & 574.1 & 41.3 \\
\hline 164-166 & 1.223 & 0.611 & 11.57 & 0.08 & 0.006 & 6.873 & 0.500 & 0.036 & 10.45 & 1.12 & 4.07 & -12.14 & 16.0 & 496.0 & 30.9 \\
\hline 166-168 & 1.115 & 0.557 & 11.64 & 0.09 & 0.005 & 6.724 & 0.500 & 0.027 & 10.44 & 1.21 & 3.90 & -12.15 & 15.7 & 654.4 & 41.7 \\
\hline $168-170$ & 1.108 & 0.554 & 11.61 & 0.09 & 0.007 & 7.165 & 0.508 & 0.037 & 10.32 & 1.29 & 3.88 & -12.43 & 16.5 & 499.7 & 30.4 \\
\hline 170-172 & 0.963 & 0.482 & 11.54 & 0.11 & 0.006 & 7.943 & 0.532 & 0.028 & 9.89 & 1.65 & 4.02 & -12.47 & 17.4 & 736.7 & 42.3 \\
\hline 172-174 & 0.956 & 0.478 & 11.42 & 0.10 & 0.005 & 6.499 & 0.464 & 0.022 & 10.06 & 1.36 & 4.19 & -12.09 & 16.4 & 768.4 & 47.0 \\
\hline $174-176$ & 1.092 & 0.546 & 11.47 & 0.10 & 0.006 & 7.323 & 0.527 & 0.032 & 10.13 & 1.34 & 4.06 & -12.60 & 16.2 & 584.6 & 36.1 \\
\hline 176-178 & 0.830 & 0.415 & 11.49 & 0.09 & 0.004 & 5.744 & 0.381 & 0.018 & 10.10 & 1.38 & 3.93 & -12.11 & 17.6 & 809.8 & 46.0 \\
\hline 178-180 & 0.817 & 0.409 & 11.60 & 0.11 & 0.004 & 6.973 & 0.434 & 0.016 & 9.90 & 1.71 & 3.66 & -11.84 & 18.7 & 1104.3 & 59.0 \\
\hline 180-182 & 1.058 & 0.529 & 11.39 & 0.10 & 0.006 & 8.138 & 0.538 & 0.030 & 9.85 & 1.54 & 4.18 & -12.19 & 17.7 & 704.2 & 39.9 \\
\hline 182-184 & 0.930 & 0.465 & 11.41 & 0.10 & 0.006 & 6.047 & 0.474 & 0.028 & 10.11 & 1.30 & 4.04 & -12.39 & 14.9 & 556.7 & 37.4 \\
\hline 184-186 & 1.039 & 0.520 & 11.32 & 0.11 & 0.006 & 7.395 & 0.567 & 0.033 & 9.90 & 1.42 & 3.97 & -12.27 & 15.2 & 574.2 & 37.7 \\
\hline 186-188 & 1.002 & 0.501 & 11.49 & 0.12 & 0.006 & 10.226 & 0.584 & 0.030 & 9.45 & 2.04 & 3.69 & -12.08 & 20.4 & 885.4 & 43.3 \\
\hline $188-190$ & 0.917 & 0.458 & 11.40 & 0.12 & 0.005 & 6.085 & 0.539 & 0.024 & 10.08 & 1.33 & 3.74 & -12.38 & 13.2 & 663.5 & 50.3 \\
\hline 190-192 & 0.921 & 0.461 & 11.42 & 0.11 & 0.006 & 9.732 & 0.521 & 0.027 & 9.31 & 2.11 & 3.95 & -12.38 & 21.8 & 925.3 & 42.5 \\
\hline 192-194 & 1.068 & 0.534 & 11.44 & 0.10 & 0.006 & 9.785 & 0.559 & 0.033 & 9.60 & 1.83 & 3.98 & -11.97 & 20.4 & 774.2 & 37.9 \\
\hline 194-196 & 0.974 & 0.487 & 11.45 & 0.11 & 0.005 & 10.387 & 0.547 & 0.027 & 9.32 & 2.13 & 4.04 & -11.78 & 22.2 & 1007.3 & 45.4 \\
\hline 196-198 & 1.075 & 0.538 & 11.53 & 0.12 & 0.006 & 10.846 & 0.638 & 0.031 & 9.51 & 2.02 & 3.76 & & 19.8 & 901.9 & 45.5 \\
\hline $198-200$ & 0.956 & 0.478 & 11.54 & 0.12 & 0.005 & 9.265 & 0.584 & 0.025 & 9.61 & 1.94 & 3.36 & & 18.5 & 957.7 & 51.8 \\
\hline
\end{tabular}




\begin{tabular}{|c|c|c|c|c|c|c|c|c|c|c|c|c|c|c|c|}
\hline Depth & $\begin{array}{c}\text { Bulk } \\
\text { Density } \\
\text { (dry) }\end{array}$ & MAR* & $\% \mathrm{C}$ & $\% \mathrm{~N}$ & $\% \mathrm{P}$ & $\begin{array}{l}\text { MAR- } \\
\text { OC** }\end{array}$ & $\begin{array}{c}\text { MAR- } \\
\mathrm{N}^{* *}\end{array}$ & $\begin{array}{c}\text { MAR- } \\
\mathrm{P}^{* *}\end{array}$ & $\begin{array}{c}\text { Total IC } \\
(\%)\end{array}$ & $\begin{array}{c}\text { Total } \\
\text { OC (\%) }\end{array}$ & $\begin{array}{c}\delta^{15} \mathrm{~N} \\
\text { (\% AIR) }\end{array}$ & $\begin{array}{c}\delta^{13} \mathrm{C} \\
\text { (\% } \% \text { PDB) }\end{array}$ & $\mathrm{C} / \mathrm{N}$ & $\mathrm{C} / \mathrm{P}$ & $\mathrm{N} / \mathrm{P}$ \\
\hline $200-202$ & 0.892 & 0.446 & 11.80 & 0.12 & 0.004 & 10.349 & 0.545 & 0.019 & 9.48 & 2.32 & 3.26 & -11.48 & 22.1 & 1391.9 & 62.9 \\
\hline $202-204$ & 0.849 & 0.424 & 11.82 & 0.12 & 0.005 & 10.437 & 0.525 & 0.022 & 9.36 & 2.46 & 3.50 & -11.68 & 23.2 & 1251.4 & 54.0 \\
\hline 204-206 & 0.952 & 0.476 & 11.72 & 0.11 & 0.005 & 10.331 & 0.530 & 0.023 & 9.56 & 2.17 & 3.71 & -12.06 & 22.7 & 1152.3 & 50.7 \\
\hline $206-208$ & 1.052 & 0.526 & 11.57 & 0.10 & 0.005 & 11.048 & 0.521 & 0.026 & 9.47 & 2.10 & 4.13 & -12.19 & 24.7 & 1111.8 & 45.0 \\
\hline $208-210$ & 1.185 & 0.592 & 11.33 & 0.08 & 0.005 & 10.601 & 0.461 & 0.032 & 9.54 & 1.79 & 4.24 & -13.15 & 26.8 & 858.5 & 32.0 \\
\hline $210-212$ & 1.298 & 0.649 & 11.30 & 0.08 & 0.006 & 10.775 & 0.498 & 0.037 & 9.64 & 1.66 & 4.84 & -13.48 & 25.3 & 746.2 & 29.5 \\
\hline $212-214$ & 1.239 & 0.619 & 11.28 & 0.07 & 0.004 & 10.218 & 0.454 & 0.025 & 9.63 & 1.65 & 4.50 & -13.47 & 26.2 & 1053.5 & 40.2 \\
\hline 214-216 & 1.202 & 0.601 & 11.36 & 0.07 & 0.004 & 8.412 & 0.427 & 0.024 & 9.96 & 1.40 & 4.58 & -13.63 & 23.0 & 918.6 & 40.0 \\
\hline $216-218$ & 1.302 & 0.651 & 11.40 & 0.07 & 0.003 & 9.049 & 0.427 & 0.021 & 10.01 & 1.39 & 4.38 & -13.12 & 24.7 & 1127.3 & 45.6 \\
\hline $218-220$ & 1.013 & 0.506 & 11.48 & 0.08 & 0.007 & 8.049 & 0.398 & 0.034 & 9.89 & 1.59 & 4.58 & -13.12 & 23.6 & 615.7 & 26.1 \\
\hline $220-222$ & 1.128 & 0.564 & 11.64 & 0.08 & 0.006 & 8.627 & 0.445 & 0.032 & 10.12 & 1.53 & 4.13 & -13.02 & 22.6 & 700.7 & 31.0 \\
\hline
\end{tabular}

*MAR - Mass Accumulation Rate, expressed as g/cm²/yr

**MAR expressed as $\mathrm{mg} / \mathrm{cm}^{2} / \mathrm{yr}$ 
Appendix 10: Florida Bay core elemental composition based on mass accumulation rate calculations. Organic carbon, total nitrogen and total inorganic phosphorus are shown.

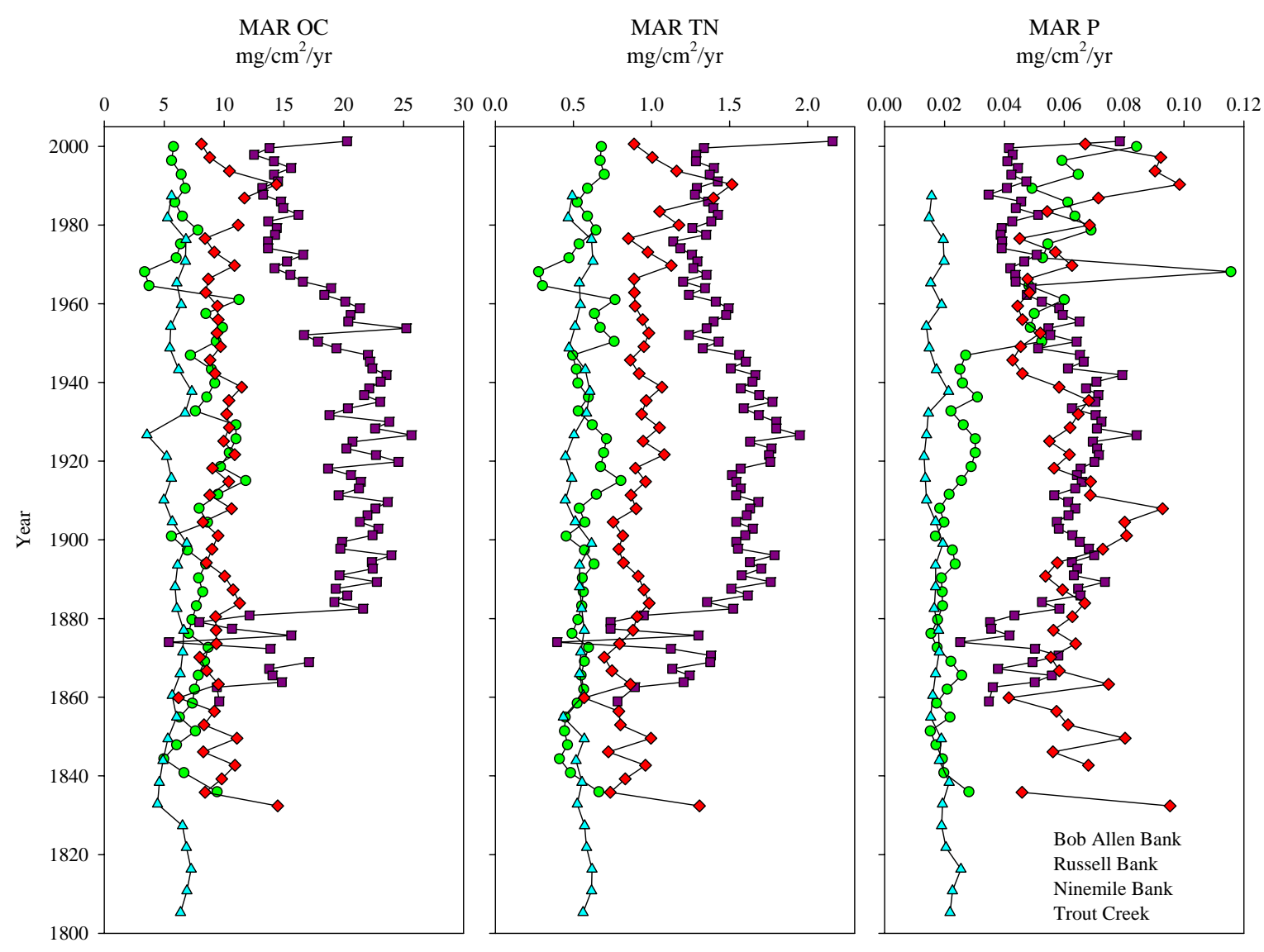


VITA

SAMANTHA L. EVANS

1993-1998 Bachelor of Science (Geology), First Class Honours, St. Francis Xavier University, Antigonish, Nova Scotia, Canada; Honours

Philip W. Oland Scholarship, St. Francis Xavier University, \$20K.

St. Francis Xavier University Alumni Recognition Award for academic excellence and contribution to the St. Francis Xavier University community. Atlantic Universities Geology Conference; APICS Prize for best scientific paper.

St. Francis Xavier University, Antigonish, Nova Scotia, Canada; Silver Medal: Highest academic average in the final three years of a degree program St. Francis Xavier University.

Professor Donald J. MacNeil Memorial Award for outstanding graduating geology student.

1998-2000 Master of Science (Biology), Florida Atlantic University, Boca Raton, Florida, U.S.A.;

Florida Atlantic University, Boca Raton, FL; Elsa Alvear Award for Excellence in Teaching.

2001-2009 Doctoral Education, Florida International University.

Florida International University GSA Scientific Forum, Best Poster:

Physical Sciences

Academy for the Art of Teaching, Florida International University;

Excellence in Teaching.

Florida International University, Miami, FL; Dissertation Year Fellowship $(\$ 20 \mathrm{~K})$

\section{PUBLICATIONS AND PRESENTATIONS}

Evans, S.L., W.T. Anderson, F.J. Jochem. 2006, Spatial variability in POM composition: combining flow cytometry with stable isotope analyses. Hydrobiologia 569:151-165.

Evans, S.L., Anderson, W.T., Jochem, F.J, Fourquerean J.W.. $2006 . \quad$ Inter-annual Variability in Stable Isotope Signatures of Size-Fractionated POM from South Florida: Influences of Nutrient concentrations. LTER National All Scientists Meeting, Estes Park, CO. [http://www.lternet.edu/asm/2006]

Wozniak, JT, Iwaniec, DM, Evans, SL, Delius B, Koch, G. 2006 Florida Coastal Everglades LTER Stident Organization: Framework and Collaborations for the Future. LTER National All Scientists Meeting, Estes Park, CO. [http://www.lternet.edu/asm/2006] 
Evans, S.L., Anderson, W.T., Jochem, F.J. 2005. Inter-annual Variability in Stable Isotope Signatures of Size-Fractionated POM from South Florida: Nutrient and Productivity Controls. Florida Bay and Adjactent Marine Systems Science Conference; Program \& Abstracts p. 99.

Evans, S.L., Anderson, W.T., Jochem, F.J., Fourqurean, J.W. 2004. Inter-annual Variability in Carbon and Nitrogen Stable Isotope Signatures of Size-Fractionated POM from the South Florida Coastal Zone. EOS Tans. AGU, 85(47), Fall Meet. Suppl. Abstract OS51-1323.

Lahera, R, Anderson, W.T.,Evans, S.L., Carroll, B, Scinto, L, Gaiser, E. 2004. Recent Paleolimnological Changes in Lake Monroe, FL, Since Time of Occupation. Environmental Sciences Research Internship Program Colloquium, June 2004.

Evans, S.L., Anderson, W.T., Fourqurean J.W., Jochem, F. $2004 . \quad$ Inter-annual Variability in POM Carbon and Nitrogen Stable Isotopes from Florida Bay and the Florida Keys, Preliminary Results. Annual Scientists Meeting, Florida Coastal Everglades Long Term Ecological Research, March 2004. Best poster, Physical Sciences, FIU GSA Scientific Forum, April 2004.

Evans, S.L., Anderson, W.T. Fourqurean J.W., Escorcia S.P., Gordon, C., Lahera, R. 2003. Stable Isotope Composition of Sedimentary Organic Matter from Florida Bay: Historic Seagrass Distribution and Paleoproductivity. All Scientist Meeting, NSF Long Term Ecological Research Program, Seattle 2003.

Evans, S.L., Anderson, W.T., Fourqurean, J.W., Jaffe, R., Gaiser, E., Collins, L., Escorcia, S. 2003. Carbon and Nitrogen Stable Isotope Composition of Sedimentary Organic Matter from Florida Bay: Evidence of Historic Seagrass Distribution and Paleoproductivity. Joint Conference on the Science and Restoration of the Greater Everglades and Florida Bay Ecosystem, Florida Bay Program and Abstracts p.166.

Evans, S.L., Anderson, W.T., Fourqurean, J.W., Jaffe, R., Gaiser, E., Collins, L.S., Holmes, C.W. 2002. Carbon and Nitrogen Stable Isotope Composition of OM from Florida Bay, the Initial Results of a Paleoenvironmental Seagrass Reconstruction. EOS Trans. AGU, 83(47), Fall Meet. Suppl. Abstract PP71B-0410.

Anderson, W.T., Evans, S.L., Pinzon, M.C., Grissino-Mayer, H.D. $2002 . \quad$ Oxygen Isotope Records from Semi-tropical Trees as High Resolution Indicators of Recent Climate Change: From South Florida to Brazil. EOS Trans. AGU, 83(47), Fall Meet. Suppl. Abstract PP52A-0317.

Evans, S.L., Mead, R.N., Anderson, W.T., Jaffe, R. 2002. Spatial and Temporal Variability of Stable Carbon and Nitrogen Isotopes in Suspended Particulate Organic Matter from a Small Tidal Estuary in Everglades National Park. EOS Trans. AGU, 83(19), Spring Meet. Suppl., Abstract H31A-03. 